\section{対側マスキングが注意課題時の 聴性脳幹反応に及ぼす效果}

○池田一成 (東京学芸大学教育実践研究支援センター) \#林 安紀子 (東京学芸大学敏育実践研究支援センター)

聴性脳幹反応 (ABR) を用いた先行研究は, 聴覚系 脳幹路において注意効果の成立が困難であることを 示してきた。一方, ABRには両耳間相互作用 (binaural interaction) が成立し，両耳が同時に刺激を受けた 場合のABR波形はIV波以降で, 片耳刺激による波形の 代数和と異なる (Levine, 1981)。しかし, ABR上の 注意効果を検討した先行研究は両耳同時提示または 対側マスキングのない片耳提示を採用しており，両 耳間相互作用の統制を充分におこなっていない。本 研究は両耳間相互作用がABR上の注意効果の検出を 困難にするという仮説を検証した。刺激条件として 両耳同時提示と対側マスキングのある片耳提示とを 設け，注意課題時のABRを両条件の間で比較した。

\section{方 法}

被験者: 正常聴力, 右手利きの健常成人12名（うち 女性6名), 平均年齢士SD, 27.6 た。刺激 : 持続 $10 \mathrm{~ms}$ (立ち上がり・下がり $5 \mathrm{~ms}$ )，音 圧80 dB SPLのピップ音を, ヘッドホンを通し刺激頻 度 $3 \mathrm{~Hz}$ で提示した（位相は毎回逆転）。刺激系列は2 種のピップ音（標準刺激と標的刺激）からなり，標準 刺激に0. $5 \mathrm{kHz}$ ，標的刺激に1 kHzを用いた。刺激提示 には2条件を設けた。両耳条件では両耳同時提示を実 施した。マスキング条件では左耳にピップ音，右耳に マスキングのため, 音圧 $60 \mathrm{~dB}$ SPLの白色雑音を連続 提示した。手続き: 各被験者につき，2つの実験課題 を各条件で実施した。無視課題では被験者に読書を課 し聴覚刺激を無視させた。注意課題では標的刺激に対 し右手でボタン押しをさせた。両課題共通に標準刺激 と標的刺激をそれぞれ確率 70 と $30 \%$ で提示した。刺激 条件・実験課題の順序は被験者6名で両耳無視, 両耳 注意, 片耳無視, 片耳注意の順で実施し，他の6名で その逆順に実施した。这波の記録と処理 : 脳波の導出 部位は国際10-20法のCzとし, 基準電極は左耳架 (A1) と右耳架 (A2) それぞれに置いた。脳波の通過周波数 は16-3000 Hzに設定した。刺激開始前 $2 \mathrm{~ms}$ と開始後 14 $\mathrm{ms}$ の記録区間をサンプリング周波数 $10 \mathrm{kHz}$ でA/D変換 したのち, 標準刺激に対し2000試行，標的刺激に対し 1000試行の加算平均をおこなった。その際, 脳波が士
$15 \mu \mathrm{V}$ 超えた試行は加算処理から除外した。事象関 連電位を分析する際の基線は刺激開始前 $2 \mathrm{~ms}$ 間の平 均とした。データ処理: 各加算平均波形に対し刺激開 始時から0.5 msごとの潜時区間における平均電位を 算出した。無視課題と注意課題の間で電位差が有意に なる潜時区間を検出するため, 各区間の平均電位に対 し対応のある1要因の分散分析を適用した。加えてIV/ $\mathrm{V}$ 波複合の頂点を潜時6.7-8.7 ms間の最大陽性電位 として算出し，振幅と潜時に対して対応のある2要因 の分散分析 (刺激条件 $\times$ 実験課題) を適用した。有意 性の基準は $p<.05$ とした。

\section{結 果}

標的刺激に対する波形では，マスキング条件の注 意課題時において, 無視課題時と比へ ABR のIV波 (6-6.5 ms)，V波 (7-7.5 ms)，VI-VII波（8-11 ms) に対応する潜時区閒で有意な陰性シフトが $\mathrm{Cz}-\mathrm{A} 1$ 導 出にのみ成立した $(p s<.05)$ 。両耳条件では注意課 題時において, $\mathrm{Cz}-\mathrm{A} 1$ 導出の潜時区間 1. 5-2 ms に有 意な陽性シフトが成立した $(p<.02)$ 。

標準刺激に対する波形では，いずれの刺激条件， 電極部位においても実験課題の問に有意差のある潜 時区間は見出されなかった。

$\mathrm{IV} / \mathrm{V}$ 波複合の振幅に対する分析では,いずれのピ ップ音, 電極部位においても刺激条件の効果が有意 になり (ps<.003), 両耳条件〉マスキング条件と なった。振幅に対する他の主効果, 交互作用は有意 でなかった。潜時に対する分析では，いずれのピッ プ音, 電極部位においても有意な主効果, 交互作用 は成立しなかった。

\section{考 察}

IV-VII波に対応する潜時区間において注意課題時 に生じた陰性シフトは，2 つの刺激条件のうちマス キング条件にのみ見られた。この結果は本研究の仮 説と整合する。ヒトのABRにおいて両耳間相互作用 はIV波以降に成立するため (Levine, 1981), 同様の 潜時区間で成立する注意効果を隠蔽するのかも知れ ない。またIV/V波複合の頂点振幅によって注意効果 が検出されなかったという事実は，注意に関連した 陰性シフトが ABR の基礎成分とは異なることを示唆 する。したがって，先行研究において ABR 上の注意 効果の検出が困難であった理由は, 両耳間相互作用 の統制を充分におこなわず，ABR 基礎成分の振幅と 潜時を指標にしたことにあると考えられる。 
標準刺湤の連続性が記憶痕跡形成と崩壊に及ぼす影響 一刺激 train 系列での MMN による検討○勝二 博亮 (茨城大学教育学部) 小川真理恵 (社会福祉法人愛孝会松ヶ丘保育園) 尾崎 久記 (茨城大学教育学部)

\section{I . 目的}

連続呈示の Standard 刺激（以下 $\mathrm{S}$ 刺激）とそれに続 いて呈示されるDeviant 刺激 (以下 D 刺激)をそれぞ れ一つの刺激群（train）とし，記憶痕跡の崩壊が始ま る train 間間隔（ITI）8秒で呈示した場合に，先行す る標淮刺激によって記憶痕跡形成と崩壊がどのように 影響を及ぼされるか MMNにより検討した。

II. 方法

1. 対象者: 健常成人 13 名（男性 2 名, 女性 11 名, CA21 : 6 23:7）。2. 刺激及び刺激系列: 刺激持続 時間は $50 \mathrm{msec}$ ，立ち上がりと立ち下がりに $5 \mathrm{msec} の$ コサインテーパリング処理した $\mathrm{S}$ 刺激 $(1000 \mathrm{~Hz})$ と $\mathrm{D}$ 刺激 $(1050 \mathrm{~Hz})$ を, 刺激強度 70dBSPL で 1 試行 につき 420 回呈示。刺激系列は $\mathrm{S}$ 刺激が 3 回連続呈示 された後に D 刺激が 1 回呈示される $3 \mathrm{~S}$ 系列 (SSSD) と $\mathrm{S}$ 刺激が 9 回連続呈示された後に D 刺激が 1 回呈 示される $9 S$ 系列 (SSSSSSSSSD) の 2 種類を, 同頻 度でかっ同じ系列が 3 回以上は連続しない上う擬似ラ ンダムに設定。train 内の刺激閒間隔 (ISI) は $500 \mathrm{msec}$ で，ITI は 8 秒に設定。3. 記録手続き：F3，Fz，F4， $\mathrm{Cz}, \mathrm{Pz}$, 左右 mastoid から鼻尖基準で脳波を導出。4. 分析:アーチファクトを除去後, 刺激呈示前 100 Omsec までの平均電位をべースラインとし, 刺激呈示 前 $100 \mathrm{msec}$ から呈示後 $400 \mathrm{~ms}$ の区間を分析。1 音目 の $\mathrm{S}$ 刺激について脳波を加算平均した Standard 波形

(以下 $\mathrm{S}$ 波形) と各系列の D 刺激について脳波を加算 平均した Deviant 波形（以下 D 波形）を求め，D 波 形から $\mathrm{S}$ 波形を引き算した差分波形（MMN： mismatch negativity）を算出。統計処理は，各部位 の $\mathrm{S}$ 波形と D 波形の振幅值について paired t-test を 実施。3Sおよび $9 \mathrm{~S}$ 系列間の MMN 振幅差について も各部位ごとに paired t-test を実施。

\section{III. 結果}

いずれの系列でも刺激呈示後 100 300 ms において, S 波形よりも D 波形は陰性に偏移していた。そこで，S 波形とそれぞれのD波形について paired t-testを実施

したところ, 刺激呈示後 $200 \mathrm{~ms}$ 付近において，9S 系列では F3, F4. Cz. Pz の各部位で有意差が生じてい たが（Fig.1，p<.05），3S系列ではいずれの部位で も有意差がみられなかった。一方，D波形から $\mathrm{S}$ 波形 を減算して得られる差分波形では，系列のいかんに関 わらず 100 250 $\mathrm{msec}$ に中心・頭頂領域優勢な陰性電 位 (MMN) が認められたが，系列間で MMN 振幅值 の違いはみられなかった。

IV. 考察

\section{Long-ITI 条件下での MMN}

系列のいかんに関わらず，D刺激から $\mathrm{S}$ 刺激を引き 算した差分波形において, MMN が刺激呈示後 100 250ms で右前頭領域と中心・頭頂領域優勢に認 められた。同じ ITI8 秒条件で実施した Gaeta et al. （2001）もやや中心領域優勢な MMN 成分を報告してい る。さらに, ITI ではないが, 刺激間間隔 (ISI)を1,

6，10 秒に設定し，MMN の出現様相を検討した Böttcher \& Ullsperger (1992) も, ISI の延長に伴い中 心部優勢にMMN成分が出現することを報告している。 したがって，刺激呈示の時間間隔が延長し，記憶保持 時間が長くなると，MMN は中心領域優勢に出現する ものと推定される。

\section{S 刺激の連続呈示数が MMNに及ぼす影響}

$\mathrm{D}$ 刺激に先行する $\mathrm{S}$ 刺激の連続呈示回数が多いほど MMN は高振幅となるが（Sams et al., 1983），本研 究では系列間で MMN 振幅に違いはみられなかった。 しかし，S 波形とD波形の振幅值の違いに注目寸ると， MMN 成分の出現潜時帯である刺激呈示後 $200 \mathrm{~ms}$ 付 近において，9S 系列でのみ $\mathrm{S}$ 波形と $\mathrm{D}$ 波形間に有意 差が生じていた。したがって，Long-ITI 条件下でも Standard 刺激の連続呈示回数を増やすことで，記憶 痕跡保持がより強固になることが示晙された。

$3 \mathrm{~S}$ 系列

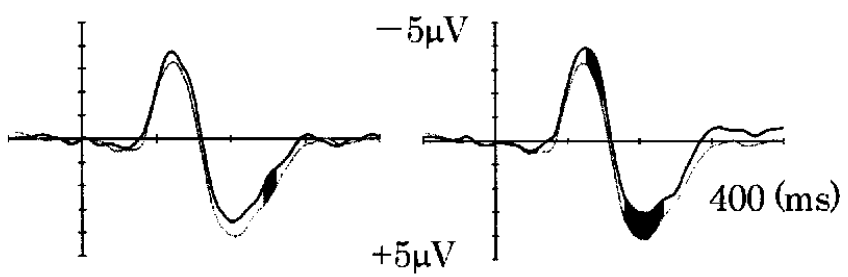

Fig.1. 各系列での $\mathrm{S}$ 波形と D 波形の重社書き（Cz) $\mathrm{S}$ 波形 (灰色) と $3 \mathrm{~S}$ 系列拉よび $9 \mathrm{~S}$ 系列の D波形 (黒色) を それぞれ重ね書きした。 paired t-testにより 5\%水準で有意差 が生じた箇所を黒滁りで示している。 
尰続音呈示中における無音部に対する聴觉処理過程

一小学生と成人との比較一

○松本 秀彦 (作新学院大学人間文化学部)

諸冨 隆 (作新学院大学人間文化学部)

豊巻 敦人 (北海道大学大学院医学研究科)

小山 幸子 (北海道大学電子研究所)

竹市 博臣 (理化学研究所)

1. 目 的

無声子音, 特殊モーラである促音, 文の切れ目 (句点 部)では，連続した音声の中に含まれる無音部（gap） の知覚が重要な役割を果たす。聴覚刺激により惹起さ れる事象関連電位のN 1 成分や MMN 成分は発達的に変 化するとされ，発話の遅れや障害は ERPs に反映するこ とが知られている。しかし，発話中に見られるような 連続音中に挿入された gap に対する中枢の反応につい ては，児童における発達的変化や成人においても十分 に検討されてきていない。

そこで，本研究では連続音に挿入される gap に対す る中枢処理の発達的変化について, 連続音中の無音聴 取時の ERPs を用いて検討を行った。

2. 方 法

対象：健常児童 8 名（男児 7 名，女児 1 名， 8 歳 10 歳）, 健常大学生 12 名（男性 6 名, 女性 6 名, 19 歳 〜22 歳) とした。

刺激 : $500 \mathrm{H} \mathrm{z}$ の純音(前後に $5 \mathrm{~ms}$ のエンベローブ)を SOA2. 8 3. 2 秒 (平均 3 秒)でヘッドフォンから提示し た。TONE条件では無音状態から持続時間 8，16,32, $64,128,256 \mathrm{~ms}$ の 6 種類の音刺激を，G A P 条では持 続的な音刺激呈示中に無音 $\operatorname{gap}$ (持続時間 $8,16,32 ， 64$, $128,256 \mathrm{~ms}$ ）を両条件ともランダムな順序で呈示した。 脳波 : 脳波は頭皮上 7 部位 $(\mathrm{Fz}, \mathrm{Cz}, \mathrm{Pz}, \mathrm{T} 7, \mathrm{~T} 8$, 左右マス トイド)から，基準電極を鼻尖部として導出した（サン プリング周波数 : $1000 \mathrm{~Hz}$, バンドパスフィルタ $0.16-30 \mathrm{~Hz}$ )。

課題: 両条件での反応時間の計測の後, 脳波計測を行 った。脳波計測時には両条件とも無音のビデオを鑑賞 してヘッドフォンから呈示される音刺激は聞き流した。 3. 結 果

行動指標: TONE, GAP 条件における反応時間は, 児童で は $256 \mathrm{~ms}$ を除いて GAP条件の方が TONE 条件よりも短か った。この傾向は成人では見られなかった。
ERPs : TONE 条件では，音刺激提示後惹起される N1 成 分は，成人と児童とで類似したパタンを示した。また， 刺激の持続時間が波形パタンに及ぼす効果は小さかっ た。GAP 条件では，成人と児童は異なる波形パタンを 示した。成人では GAP 長の変化と共に波形パタンが変 化した。これは正中上 $(\mathrm{Fz}, \mathrm{Cz}, \mathrm{Pz})$ と左右のマスト イド（M1，M2）で影著であった。無音部が $64 \mathrm{~ms}$ 以上 になると音刺激の再開後約 $110 \mathrm{~ms}$ 後に $\mathrm{N} 1$ 様の成分 (N1 b ）が出現した。児童では成人と比較して全体に波形 の振幅が大きく,特に Fz では無音部の開始により惹起 される N1a が持続し，成人における N1b と思われる成 分に重畳した。また，側頭部（T7，T8）の記録は正中 上とマストイドとは異なり, TONE 条件では 2 䓓性の頂 点が認められた。これは児童の左側頭で顕著であった。

\section{4. 考 察}

児童では成人に比べ反応時間が全体に長く，また成 人と異なり TONE条件よりもGAP条件の方が短かったこ とから，児童期においては，短時間無音部に対する検 出力が TONEよりも優れていることが示唆された。

また, $\mathrm{N} 1$ 成分の振る舞いが GAP 条件において児童と 成人とで異なっていることから，坚童期の中枢聴覚処 理過程は音刺激の ONSET に対しては成人と同様の処理 がなされているが，短時間の無音部検出については成 人と異なり発達の途上にある可能性が示された。

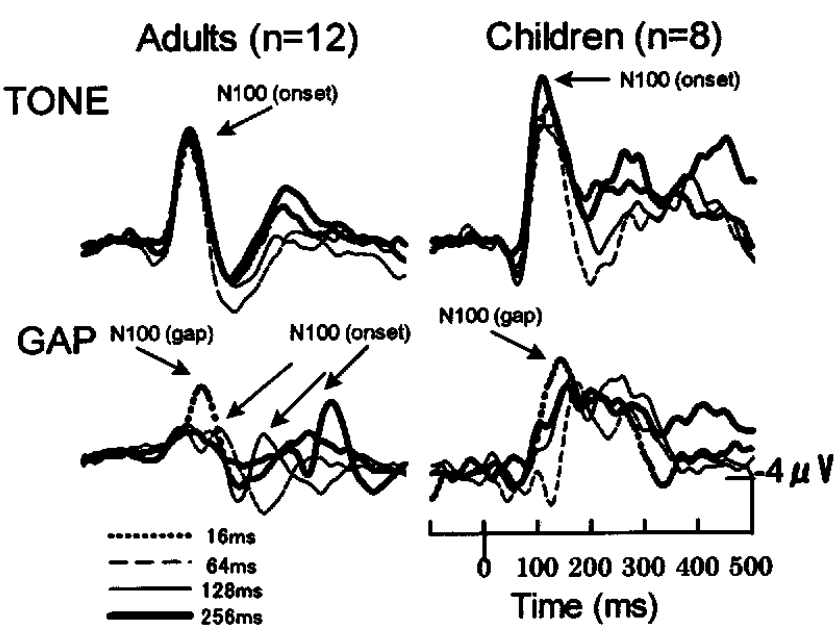

Figure 1. TONE, GAP 条件で得られた ERPs

謝辞 : 本研究実施にあたり, 船田元作新学院理事長, 山田一 雄小学部長, 平成 17 年度卒業石原勝経氏に多大な協力を得 ましたこと感謝いたします。この研究はJST 脳科学と教育 プロジェクト(代表小山)による援助を受けた。 
メロディ認知に影電を及ぼす音列搆成アルゴリズム

○福井 ゆきの（福息大学大学院教育学研究科）

福田 一彦（福島大学共生システム理工学類）

音楽は民族を超えて普遍的に存在するという事実か ら, 音楽成立には人類共通の普遍的プロセスが存在し, それが生物学的に規定されている可能性が考えられる。

そこで本研究では，音楽認知の背景にあると考えら れる人類に普遍的な生物学的プロセスを明らかにする ことを目的とした。

\section{実験 1}

複数の単純な音列の構成原理を用いて、メロディら しさに影響する構成原理について検討した。

【仮説】 2 種類の仮説に基づき研究を進めた。 (1)音列がランダムな状態 (random) から単一の音が続 く状態（order）まで変化した場合,その中間領域にお いてはじめてメロディとして認識されるのではないか。 (2)音楽の中には “よく使用される音” が存在し，その 音の使用頻度がメロディらしさに影響するのではない か。

\section{【方法】}

被䀦者 大学生 230 名（男性 150 名，女性 80 名）。 手続き 音刺激を呈示し, Visual Analogue Scale に より「メロディらしさ」を主観評価させた。

刺激 音列はコンピュータのランダム関数を用いて 生成した。全ての音は半音単位で C4 から C5 までの 13 音から抽出し、各系列は 5 音からなる。

音列は全部で 3 種類生成した。仮説(1に基づき，音 階全体の幅を狭めていくパターン 1(1)（生成した音列 は random, 11 音階, 9 音階, 7 音階，5 音階，3 音階, order の 7 群)，1 つの音に着目し次に来る音の選択範 囲を狭めていくパターン1(2)（生成した音列は間隔 11, 間隔 9 , 間隔 5 , 間隔 3 , これに random，及び order を加えた 7 群）を，仮説(2)に基づき，様々な民族の音 階から使用頻度の高い音を抽出し, 使用音の種類を減 らしていくパターン2（生成した音列は 7 音, 5 音, 3 音ここれに random, order を加えた 5 群）を生成した。

【結果と考察】パターン毎に対応のある 1 要因分散 分析を行った結果, 全てのパターンで有意な主効果が 認められた。（パターン 1(1)：F $(6,1603)=44.552, \mathrm{p}$ <.01, パターン 1(2): F $(6,1603)=60.095, \mathrm{p}<.01$, パターン $2: \mathrm{F}(4,1145)=133.835, \mathrm{p}<.01)$ 。パターン
1(2)では間隔 7 群が,パターン 2 では 5 音群が最もメロ ディらしさの評価が高く他群との有意差が認められた。 パターン 111ではメロディらしさの評価が突出して高 い群はなかったが, order 群の評価が極端に低いため 有意差が出たのではないかと考えられる。また，各パ ターンのピーク平均值を比較した結果, パターン 2 が 最も高く, 次いでパターン1(2),パターン1(1)となった。 以上のことから，メロディらしさには音を選択する ある程度の範囲は必要ではあるが，\#などの普段使用 頻度の少ない音が多く使用されるとメロディらしさは 低くなると考えられる。よって，メロディらしさには 音の選択範囲と同時に，使用する音の種類というもの が大きく影響しているといえるだろう。

\section{実験 2}

【目的】実験 1 で得られたメロディらしさの評定平 均値が異なる音列を用いて, 調性構造の処理について 事象関連電位を用いた予備的検討を行った。

【方法】被験者 大学生 2 名（女性 2 名）。

手続き 実験 1 で評定平均值が最も高く, 使用音の種 類に着目して生成した 5 音群, 他に random 群, order 群の音列を呈示刺激として用いた。

被験者に受動的に音列を聴取させた。その際, 頭皮 上 15 部位の脳波記録を行い, 各音の呈示開始時点を基 点として加算を行った。

\section{【結果と考察】}

random 群，5音群 (Melody 群)，order 群の 3 種類 の音列刺激に対する左右頭頂部(P3，P4)における波形 をみると、全ての群で N1 と思われる陰性方向の電位が 生じ，この振幅は, order 群において小さかった。こ れは, N1 は刺激の物理特性等に依存して生じる定位反 応成分と考えられるため, 同じ音程の音が続く order 群では小さくなったと考えられる。

N400 の振幅に関して左右差が認められた。order 群, random 群では右半球 (P4) に比べ, 左半球 (P3) で N400 と思われる陰性電位が大きかったが, melody 群に おいては他の 2 群に比べ右半球において比較的大きな N400 が生起し，左右差は認められなかった。 N400 成 分は意味的逸脱に対し生起する成分であり，これは右 半球がメロディらしいものを選択的に処理している可 能性を示唆している。しかし今回の実験は被験者数が 少なく予備的なものであるため、今後、更に被験者を 增やし検証していく。 


\section{クロスモダリティエフェクトの生理心理学的検討 \\ ○金山範明 (名古屋大学大学院䝸境学研究科) \\ 佐藤 徳 (富山大学人間発遠科学部) \\ 大平 英樹 (名古屋大学大学院沶境学研究科)}

\section{1. 目的}

本学会

人間は常に様々な環境からの情報入力を受けて存 在している. その情報入力とは人閒の感覚受容器によ って起こされる知覚であり, 求心性の神経を通して脳 に伝えられている。これまでモダリティの異なる各知 觉現象一視覚・聴覚・体性感覚・嗅覚などーは別々に 扱われてきたが，人閒が何らかの情報を得るとき，そ れは単一モダリティからの入力であることは少なく， ほとんどの場合異なるいくつかのモダリティからの入 力である. より現実的な人間の知覚現象を捉えるため に, 最近では知覚のモダリティ間統合に関する研究が 盛んになってきている(Calvert, 2004).

クロスモーダルに注意の影制が現れることは既に 視覚一体性感觉間で示されており (Eimer et al, 2000)， N140というERP成分の増幅に体性感喾への注意が表れ ることが明らかにされた. しかし，本研究ではN140と いら成分にはっきりとした条件差が見られなかった. ここでERPはいくつかの独立成分が重量している可能 性が高いことを考慮し，脳波を独立成分に分解しより 詳細な検討を行った。

\section{2. 方法}

被験者 11名 (女性6名, 男性5名, 年齢19-22歳)の 大学生健常者が参加した. 参加者は全員右利きであり, 視覚異常を呈することはなかった. 全ての参加者にお いて畵面によるインフォームドコンセントが取られた.

刺激と装置 体性感觉刺激は二つの振動モーター により，それぞれ人差し指及び親指に呈示した. 実験 参加者には振動モーターを取り付けた発泡スチロール のキューブを，振動がそれぞれ独立に人差し指及び親 指に与えられるようつまんで持たせた. 視覚刺激は台 上に謴かれた発泡スチロールキューブに取り付けられ たLED(赤)により呈示された。LEDはそれぞれキッチン グローブの人差し指及び親指に取り付けられているよ うに配置された. また視覚刺激までの距離は60cmに統 制された。視覚刺激は体性感觉刺激同様 Presentation0.81によって制御された.
手続き 実験協力者は左手にゴム手袋をし，振動モ 一ターの付いたキューブを人差し指と親指でつまむよ うにして持ち, 中が不可視になっている箱状の台に手 を入れた. 腕は台の下のレスト台に置かれた. 台上に は同じゴム手袋がLEDの付いたキューブを持つ形で置 かれており，寒験中はこのLEDを注視していることが教 示された. 人差し指への刺激を「上」, 親指への刺激を 「下」として教示した. 実験課題中は部屋の明るさを 30luxに保った. 二つのLEDの点灯により実験開始が示 され続いて課題が提示された.課題はLEDの消灯による 150msの瞬き禁止区間の呈示, 課題としてLED及ひ振動 モーターの同時呈示 (300ms), 100msのブランク, $150 \mathrm{~ms}$ の瞬き可能区間を表すLEDの点灯を1試行とし, 1ブロッ ク80試行で，4ブロック行った. 剌激は8条件 ((LED, 振 動) = (上, 無), (下，無), (無, 上), (無,下), (上, 上), （下，下），(上,下），(下，上))でそれぞれ10試行ずつ 呈示され，実験協力者はそれぞれ振動刺激の位冓(上， 下，無)で判断しボタン押しにより回答した.

\section{3. 結果と考察}

実験参加者ごとに独立成分分析を行い，各独立成分を 算出した. その後クラスター解析により各参加者ごと の独立成分をクラスタリングし，15のクラスターを得 た(Figure1).

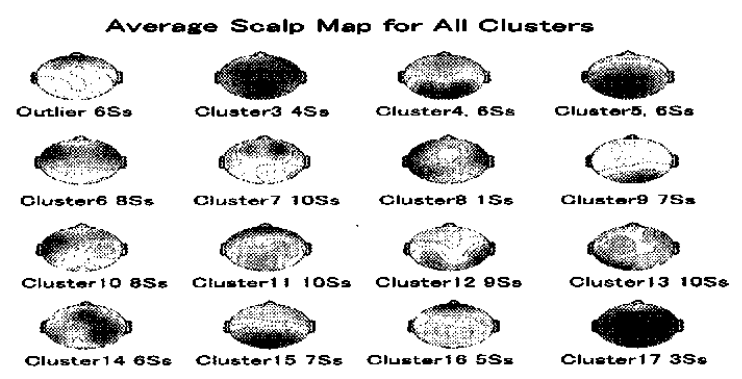

Figure 1. ICAクラスタリングのトポグラフィー

$\mathrm{N} 140$ 成分が見て取れるクラスターに対し時間周波数 解析を行ったところ, N140 様の挙動が確楒された. こ れにより, ERPにおいてN140が確認されなかったのは 他成分の重疊であった可能性が示唆された.
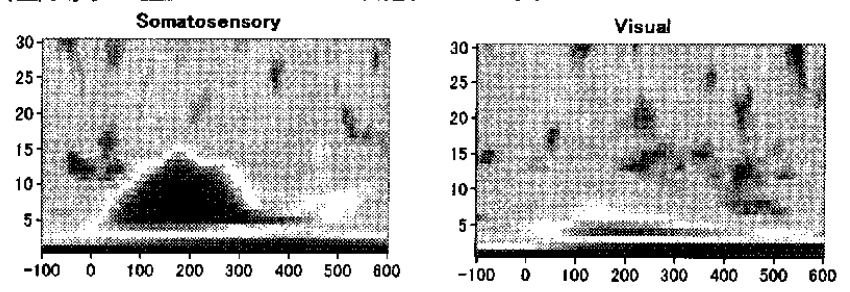

Figure2.ERP 成分の InterTrialCoherence 


\section{視覚性変化検出を反映する変化関連陽性成分に 対する空間的注意および特徵注意の影響 \\ ○木村 元洋 片山 順一 室橋 春光 (北海道大学大学院教育学研究科)}

時間的に連続して呈示される $2 つ の$ 視鸴刺激間の変 化検出を行う S1-S2 マッチング課題において, 変化 S2 呈示時には，S2 呈示後約 100-200 ms で後頭部優 位の陽性の ERP 成分 (change-related positivity, CRP, Kimura et al., 2005, Psychophysiology) が惹起する。 CRP は，注意が向けられている位置や特徴における 変化に対し明瞭に惹起するが，非注意位置や非注意 特徵での変化に対する惹起様相に関する研究は少な い。本研究では，CRP が前注意的な変化処理を反映 するかを検討するため，この成分に対する空間的注 意と特徵注意の影響を検討した。

\section{方 法}

被験者 視覚に問題のない大学生・大学院生 10 名 刺激及び手続き 色 (赤・青) と空間周波数 $(1.0 \mathrm{cpd}$ $6.0 \mathrm{cpd}$ ) の直交による 4 種の図形（視角度 $4.0 \times 4.0^{\circ}$ ) を用いた。これらをディスプレイ上の左右に配し， 各 S1 と S2 を構成した。5 種の S1-S2 タイプを等確 率 $(p=.20)$ でランダム順に呈示した : 左右変化な ᄂ, 左色変化, 右色変化, 左周波数変化, 右周波数 変化。S1 と S2 の持続時間は $100 \mathrm{~ms}, \mathrm{~S} 1-\mathrm{S} 2$ 間のブ ランクは $400 \mathrm{~ms}$ であった。課題は, 一方の位置（右 または左）における一方の特徵（色または周波数） の刺激変化に対するボタン押しであり，各被験者は 計 4 種の課題をランダム順に行った。反応手はブロ ック間でカウンターバランスをとった。

記録 EEG は鼻尖を基準として頭皮上 25 部位より 導出した。各 S2 に対する電位を, 刺激呈示前 $100 \mathrm{~ms}$ 間の平均電位を基準として刺激呈示後 $700 \mathrm{~ms}$ まで 加算平均処理した。バンドパスフィルタは 0.1-20 Hz, サンプリングは $250 \mathrm{~Hz}$ とした。

分析 色変化および周波数変化効果をもとめるため, 課題条件毎に変化刺激に対寸る波形から不変刺激に 対する波形を引き算し差波形をもとめた。さらにそ れらの差波形を, 課題との関係性から 4 種の注意条 件に分類した: 注意位置での注意特徵変化 $(\mathrm{S}+\mathrm{F}+)$, 注意位置での非注意特徵変化 $(\mathrm{S}+\mathrm{F}-)$, 非注意位置 での注意特徵変化 $(\mathrm{S}-\mathrm{F}+)$, 非注意位置での非注意
特徵変化 $(\mathrm{S}-\mathrm{F}-)$ 。標的刺激である $\mathrm{S}+\mathrm{F}+$ に対しては 選択関連電位（e.g., selection negativity）の重畳が見 られたため，本報告では非標的刺激における刺激変 化効果のみを報告した。また行動指標および ERP 波 形における明瞭な左右差がなかったため, 左右の条 件を平均化したデータを示した。

\section{結果及び考察}

Figure 1 に，各注意条件における色および周波数の． 変化効果を表す差波形を示した。変化刺激に対する 最も早い変化効果は, S2 呈示後約 100-200 ms にお ける後頭頭頂部優位の陽性成分（CRP）であった。 色変化に関し, CRP は被験者の注意条件に関わらず 同様に惹起した。さらに, S+F-の場合には中心部優 位の N270 と中心・頭頂部優位の LPC, S-F+の場合 には N270 のみがそれぞれ後続した。一方，周波数 変化に関しては, S+F-と S-F-の場合に CRP が観察 された。また $\mathrm{S}+\mathrm{F}-の$ 場合には N270 と LPC が後続 した。両特徴において非注意位置での非注意特徽の 変化に対し CRP が得られた結果は,この成分が前注 意的な変化処理を反映することを示す。 $\mathrm{S}-\mathrm{F}+$ 周波 数変化に対し CRP の惹起が見られなかった結果は, 近年, Sussman et al. (2003, Psychophysiology) が提唱 している変化処理の競合仮説の観点で解釈できる可 能性があるが，今後の検討が必要である。

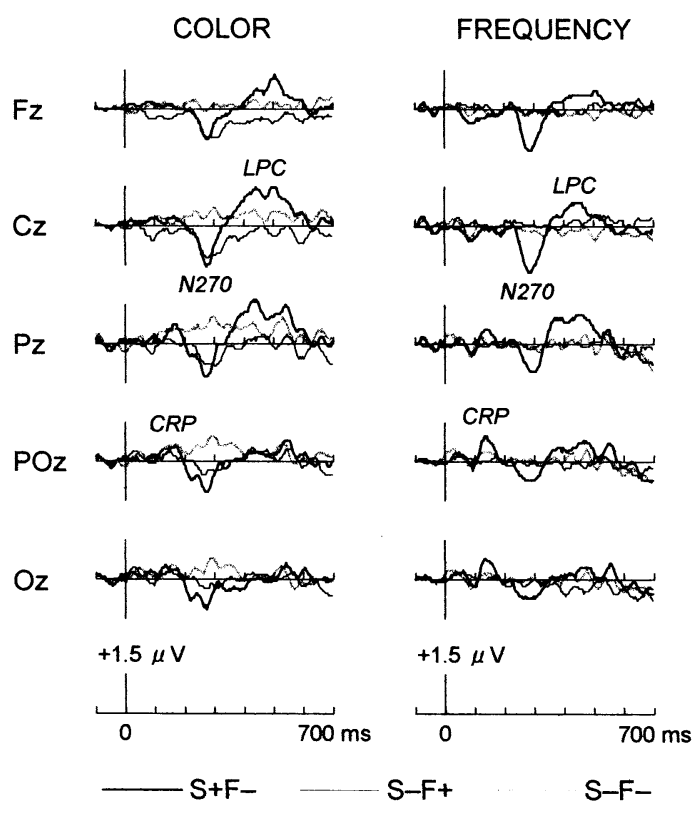

Figure 1. Change - no-change difference waves (Left: color change effects, Right: frequency change effects). 


\section{TVキャプチャ画像に対する期待はずれに関連した 事象関連電位}

○足立 信夫, 森川 幸治

（松下電器産業(株）先端技術研究所 知能情報技術研究所）

\section{1. 背景と目的}

行為を起点に提示された刺激に対する Event-Related Potential (ERP) 計測において, フィードバック (Feedback: FB)の内容を予期して行為を選択した場合に, 予期と実際の FB との不一致に関連して潜時 550$600 \mathrm{~ms}$ に陽性成分が出現することを報告した[1]. しか し報告[1]では FB が文字列で与えられ，知覚的なイメ 一ジとしても予期が可能な条件であったため, 出現し た成分が認知的もしくは知覚的のどちらの不一致を反 映していたかの区別ができていなかった.

本稿では，FB に対して知覚的な予期が持てない条 件として，同一番組から複数のシーンを抽出した TV キャプチャ画像を用いて実験を実施し, 認知的な不一 致に関連した ERPに関して報告する.

\section{2. 方法}

参加者 : 正常な視力または矯正視力を有する右利きの 大学生 8 名.

FB : 知覚的予期をさせないために, 3 ジャンル（二ュ 一ス $\times 2$, アニメ×2, バラエティ×2）の 6 つの TV 番組それぞれから 6 シーンずつ抽出し，計 36 枚のキ ヤプチャ画像を用意し, 各試行で一枚の画像を提示し た（視角 $8.1^{\circ} \times 10.8^{\circ}$ ). チャンネル番号は画像右上に 大きく表示した（視角 $1.0^{\circ} \times 0.8^{\circ}$ ).

手続き：参加者には，ディスプレイに提示される (a) チャンネル番号（数字 : 4, 6, 8), (b) 番組ジャンル (ニュース, アニメ, バラェティ), (c) 番組名のいず れかの属性に関する選択の指示を見て，指示に対応す るキ一を選択・押下し, 選択に応じて提示される TV キャプチャ画像に注意するよう求めた（一致条件： Match).ただし, 不一致条件として，選択とは属性が 異なる TV キャプチャ画像を 0.5 の確率で提示した (Mismatch). 試行の繰り返し回数は 120 回とした. ERP 記録: 両耳染を基準として頭皮上 19 部位(FP1, FP2, F3, F4, C3, C4, P3, P4, O1, O2, F7, F8, T3, T4, T5, T6, $\mathrm{Fz}, \mathrm{Cz}, \mathrm{Pz}$ ), 右眼營下，右眼角外加ら記録した。時定 数は 3 秒，サンプリング周波数は $500 \mathrm{~Hz}$ とした. FB 提示時点を基準に，-100〜1000ms の区間を加算平均
した（ベースライン補正 : $-100 〜 0 \mathrm{~ms}$ ). 最大振幅が $100 \mu \mathrm{V}$ 以上であった試行は，加算から除外した。

3. 結果

図 1 に被験者 8 人の総加算平均波形を示す. (b) で は FB の知覚的予期ができない条件にも関わらず，(a), (b) どちらの条件でも, 不一致条件で潜時 $600 \mathrm{~ms}$ 前後 にピークを持つ陽性成分が出現した. 被験者ごとに求 めた区間平均電位（潜時 $500-700 \mathrm{~ms}$ ）の $\mathrm{t}$ 検定を実施 した結果，(a),(b) とも不一致条件で有意に区間平均電 位が大きかった $(\mathrm{p}<0.05)$.
(a) チャンネル番号
(b) 番組ジャンル

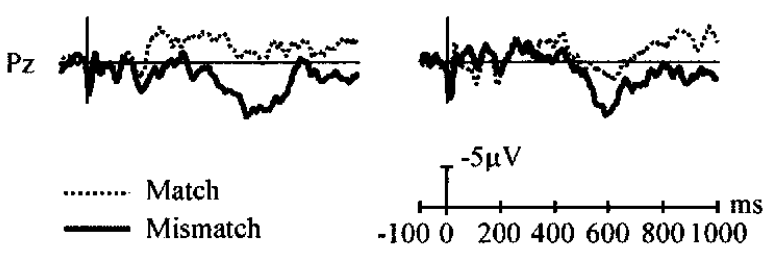

Figure 1. 総加算平均波形 $(\mathrm{Pz})$

\section{4. 考察}

実験では，各番組はそれぞれ異なる 6 シーンの画像 を含み，FB をイメージとして知覚的に予期できない ため, 提示された画像から番組ジャンル等を認知し, 指示された番組属性とマッチングする必要があった. そのため, 不一致条件で出現した $600 \mathrm{~ms}$ 前後の陽性成 分は, 知覚的なミスマッチではなく, 認知的なミスマ ッチを反映していると考えられる.

また，予期できない新奇刺激に対する ERP として は, Novelty P3[2]がある。本実験の FB は初めて目に するという意味でイメージが予期できない新奇刺激で あるが，番組内容に関しては認知的な予期ができてい る点が異なっている.

\section{5.まとめ}

TV キャプチャ画像に対する期待はずれに関する事 象関連電位の実験により, 特徴的な $600 \mathrm{~ms}$ 前後の陽性 成分は, 知覚的ミスマッチではなく, 認知的ミスマッ チを反映している可能性があることを示した.

今後は, 本研究で見出された認知的ミスマッチが発 生する条件の明確化, 具体的には行為の選択が期待は ずれの必要条件かについて調査する予定である. 引用文献

[1] 足立, 他 : 生理心理学と精神衛生学 ; Vol. 23 No. 2: 167 (2005)

[2] Polich J, Comerchero M. D: Brain Topography; Vol. 15 No. 3 (2003) 


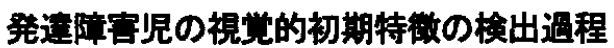

○片山 萌 (高知大学大学院教育研究科)

寺田 信一 (高知大学教育学部)

\section{1. 研究の目的}

ポップアウトは，目標刺激と妨害刺激の関係が単一 の初期特徵で定義される場合, 直ちに目標刺激が発見 できることから前注意過程での自動処理と考えられる。 集団が同じ動きをしている時に，1 人だけ違う動き をしていることに注意を向けられることは，生活上必 要なことであろう。

本研究の目的は, 発達障害児の運動方向が違うポッ プアウト刺激に対する ERP から，視覚的注意機能を探 ることである。

\section{2. 方法}

1) 対象者: 発達障害児 11 名 (CA:5 歳 4 力月-14 歳 2 力 月, $\mathrm{DA}: 4$ 歳 3 力月 -16 歳 7 力月), 健常成人 20 名 (男女 各 10 人)。

2)刺激材料 : 標準刺激は直径 $2^{\circ} 53^{\prime}$ の 7 個の緑りん ご, 同一移動刺激は 7 個のりんご全体が右斜め下に移 動, 単独移動刺激は 6 個が右斜め下に移動し， 1 個が 右斜め上に移動。

3) 手綍き : 標準, 同一移動, 単独移動刺激を $6: 2: 2$ の 割合でランダムに呈示する。

4)媨波：脳波は国際 $10-20$ 法に準じ Fp1, Fp2, F3, F4, C3, C4, P3, P4, 01, 02, F7, F8, T5, T6 の 14 部位から右耳架を基準電極として導出した。また，眼 球運動と心電図のモニターのために，右眼窩上下より 垂值眼電図を，左右鎖骨中点より心電図をそれぞれ導 出した. 脳波記録は $200 \mathrm{~Hz}$ で A/D 変換したのちパーソ ナルコンピュータのハードディスクに記録した。

5)分析方法: $150 \mu \mathrm{V}$ 以上の電位が認められる場合は除 外した. 各加算回数の平均は, 標準刺激は健常成人で 263 回，対象児で 294 回，同一移動刺激は健常成人で 54 回, 対象児で 60 回, 単独移動刺激は健常成人で 58 回，対象児で 68 回であった。次に，冕脱刺激波形より 標準刺激波形を引算した差分波形の刺激前の 6 ポイン トと 0 から 6 ポイントを 1 ポイントずらしで $450 \mathrm{~ms}$ ま での 6 ポイントずつの間で paired $\mathrm{t}$ 值を算出した。そ の $\mathrm{t}$ 值が $\mathrm{P}<0.05$ の基淮を越えない場合は除外した。

3. 結果

健常成人では，第一陽性成分 (115ms-130ms) と第二 陰性成分 $(170 \mathrm{~ms}-205 \mathrm{~ms})$ で単独移動刺激の振幅が同一

移動刺激よりも振幅が大きかった。発達障害児 $\mathrm{A}$ 群 (乳 児重ミオクロニーてんかん 1 名, MR1 名, 自閉症 1名) では，単独移動刺激において後頭部，頭頂部で第一陽 性成分のみ振幅が明膫であった。一方，第二陰性成分 では振幅の差異が認められなかった。B 群 (MR1 名，自 閉症 3 名) では, 後頭部は第一陽性成分, 第二陰性成分 ともに同一移動刺激と単独移動刺激の振幅が同レベル であった。頭頂部では第一陽性成分がみられたが，第 二陰性成分は不明瞭であり，単独移動刺激は低振幅で あった(Fig. 1)。C 群(自閉症 1名, ADHD2 名)では, 後 頭部は第一陽性成分も不明膫であり，右頭頂部では単 独移動刺激は低振幅であった。D 群(聴覚障害 1 名)で は，特異的な反応として右半球と左半球で大きな差が みられた。

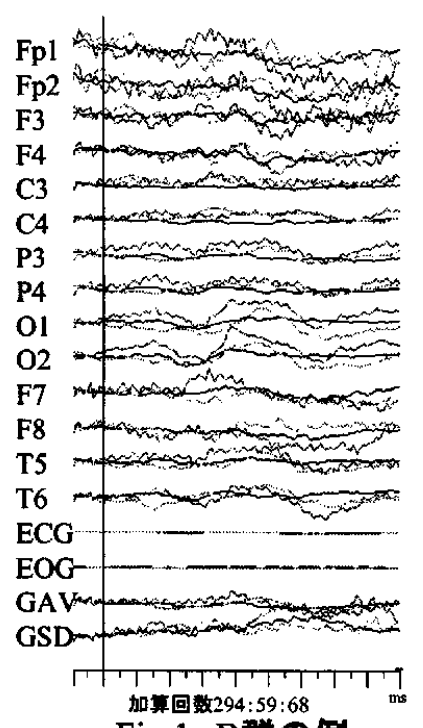

Fig.1 B群の例

\section{4. 考察}

健常成人は第一陽性 成分と第二陰性成分の 時間帯 (125ms-185ms)に 単独移動刺激に対して 電位の変化が認められ た。この時間帯に異なる 運動方向に対する弁別 に関わる空間処理が右 頭頂部でなされた可能 性がある。

発達障害児において, $\mathrm{A}$ 群は，第一陽性成分に 関わる脳内処理過程は 健常成人と同様である と考えられる。B 群には自閉症児が多く，第 1 次視覚 野に相当する後頭部でりんご一つ一つの運動方向の分 析的な反応が生起するものの，頭頂部では一つ一つの 運動方向を統合する反応が生起しなかったと推測でき る。これは自閉症児の中枢性統合の弱さに関わると考 えられる。C群では，ADHDの 2 例ともこの群に分類さ れたことから，注意の分配と関係すると考えられ，刺 激の情報量が多すぎたためと推測できる。

\section{5. 結論}

運動方向が異なる刺激に対する事象関連電位は、自 閉症の知営統合の弱さや ADHD の注意分配の障害を評 価する客観的な指標として有効であることを示唆した。 


\section{注意の視野間切り換えと $\mathrm{N} 400$ 減衰}

○安田 恭子 (愛知淑徳大学大学院コミュニケーション研究科) 沖田 庸高 (無知淑徳大学コミュニケーション学部)

【目的】Bentin \& McCarthy（1994）によれば，意味表 象アクセスを反映する $\mathrm{N} 400$ の直後反復効果は, ワーキ ング・メモリに保持されている直前の試行に関する意 思決定を採用することにより, 意味アクセスが省略さ れたために生じるという。沖田・治部（2002）は，こ の仮説に基づき, 注意切り換え時のワーキング・メモ リ中央実行系の特性を操ったところ, 注意切り換えに より, 先行意志決定情報が消滅する知見を得た。本研 究では，彼らの手続きに準拠し，モダリティを聴覚か ら視覚へと変更し, 注意の視野間切り換えによる直後 反復効果について検討した.

【方法】実験参加者 : 正常な視力を持つ大学生・大学 院生 10 名（女性 5 名, 男性 5 名）, 平均年齢 24.2 歳 $(\mathrm{SD}=5.3)$. 刺激: 維表記されたひらがな 3 文字緅り。 実検装置 : 脳波は，国際 10/20 法に従い，頭皮上 19 部位より鼻尖を基淮電極として導出した $(0.05-30 \mathrm{~Hz}$ フィルタ使用). 同時に, 左右外眼角側方的 $1.5 \mathrm{~cm}$ よ り水平眼球電図(EOG)を導出した. これらの生体電気 信号は, 刺激コードと反応信号とともに, サンプリン グ周波数 $200 \mathrm{~Hz}$ で A/D 変換した. 手綂き : 凝視点か ら視角 $2^{\circ}$ で左右視野に呈示された縦 3 文字経りにつ いて語彙判断課題を課した。 各試行は、手がかり刺激 (矢印)の提示 $500 \mathrm{~ms}$ に始まり, 空白 $500 \mathrm{~ms}$, 第一刺激 対 $100 \mathrm{~ms}$ 提示, 空白 $1400 \mathrm{~ms}$, 第二刺激対 $100 \mathrm{~ms}$ 提 示, 空白 $1900 \mathrm{~ms}$ で構成された。1ブロックは 50 試行 から成り, 最初の 2 試行はダミ一試行とし分析対象か

Nor-sw itch
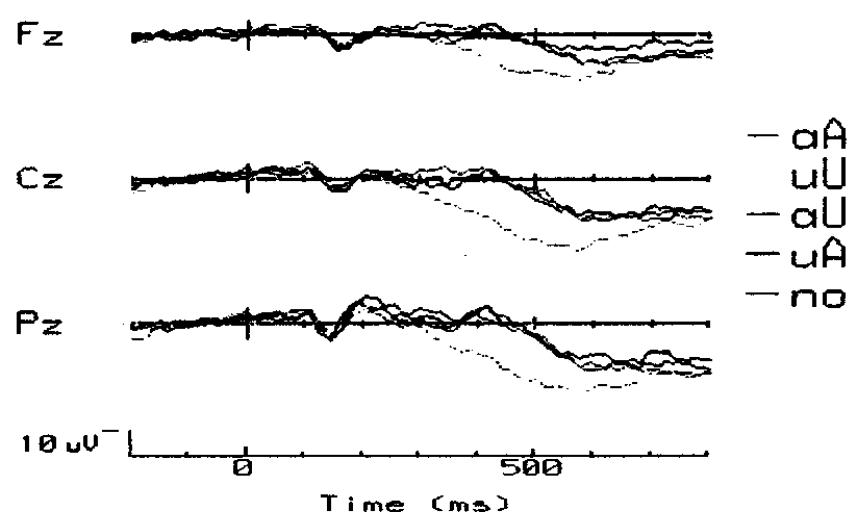

ら除外した. 注意固定 $(\mathrm{NSw})$ と注意切り換え $(\mathrm{Sw})$ の 2 条件を設定し, さらに各注意条件内には, 反復提示刺 激に関して, 注意側一注意側反復刺激呈示 $(\mathrm{aA})$, 注 意側一非注意側反復刺激呈示 $(\mathrm{aU})$ 非注意側一注意 側反復刺激呈示 $(\mathrm{uA})$, 非注意側一非注意側反復刺激 呈示 (uU) の 4 条件を設けた. 実験参加者には非単語 の検出を要請した.

【結果】 2 (注意条件 : NSw/Sw) $\times 4$ (条件 : $\mathrm{aA} / \mathrm{aU}$ / $\mathrm{uA} / \mathrm{uU}$ ) $\times 3$ (部位 : $\mathrm{Fz} / \mathrm{Cz} / \mathrm{Pz}$ ) の 3 要因分散分析を 行った結果, 交互作用 (注意条件 $\times$ 条件 $(F(2.43,21.91)$ $=3.80,(p<.05))$ が有意であり，単純主効果は，NS $\mathrm{w}$ 条件における条件の主効果が有意であった（aA > $\mathrm{uU} \quad(p<.05), \mathrm{aA}>\mathrm{uA}, \mathrm{aU} \quad(p<.10))$. すなわ ち, aA に関して視野間で注意を切り換えない条件 （NSw）において直後反復効果を示寸 $\mathrm{N} 400$ 振幅減衰 が認められ，視野間で注意を切り換える条件 $(\mathbf{S w})$ で はそのような効果は見いだされなかった (Figure 1).

【考察】聴覚モダリティ同様に視覚モダリティにおい ても，NSw/aA では，直後反復効果による N400 减衰 が確認され，NSw/aA 以外の条件では $\mathrm{N} 400$ 减衰は確 認されなかった. したがって，ワーキング・メモリに おける中央赛行系の情報調整は，モダリティに関わら ず音韻ループを用いると直後反復 $\mathrm{N} 400$ 堿衰が生じる が，注意の対象外となった刺激にはプライミング効果 が消失することが視覚刺激でも確認された，注意の対 象外の刺激情報に関しては, 情報自体が消滅してしま ったためであるのか（先行意志決定情報消滅説），ある いは他チャンネル入力情報に対する意志決定情報を単 に利用できないためであるのか(位置情報妨害仮説)，議 論の余地が残る.

(YASUDA Yasuko, OKITA Tsunetaka) Sw itch
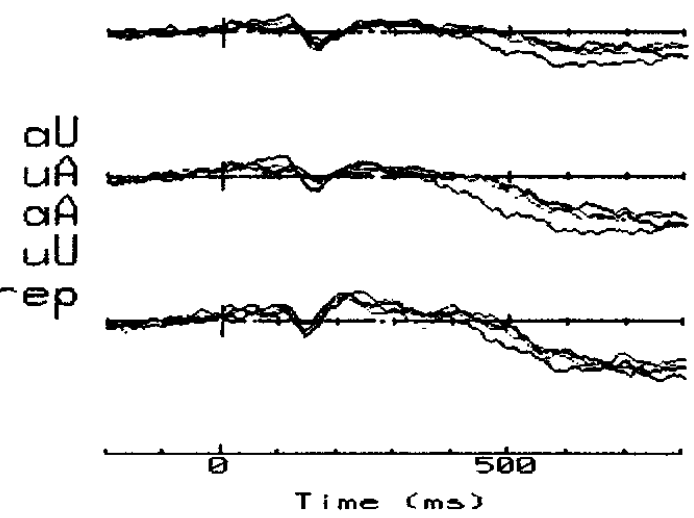

Figure 1. 条件別第 2 刺激対に対する総加算平均 ERP 


\section{課題の難易度が}

聴賞ディストラクション効果に及ぼす影響

○清家 美子・片山 順一

(北海道大学大学院教育学研究科)

ディストラクションとは, 課題非関連な刺激属性が低頻 度で逸脱することによって注意が捕捉され課題遂行が阻 害される事態であり，その効果は反応時間（以下 RT）の 遅延といった行動遂行の低下に表れる。冕脱情報処理に は, 前注意過程で変化を検出する段階, 逸脱情報へ不随 意的に注意が転換する段階, そして逸脱刺激を同定する 段階があり，ERPではそれぞれがMMN，P3a，P3bに反映 される。本研究では, 課題遂行に必要な注意資源の量の 違いがディストラクション効果にどう影響するのかを明らか にするために, 并別課題の難易度を操作し, 并別課題遂 行時の行動反応および ERPによる検討を行った。

\section{方 法}

【被験者】聴覚の正常な大学生および大学院生 15 名。

【刺激・手続き】課題は, 左右のボタン押しを求める持続 時間弁別課題で, 持続時間の弁別の難易度を 2 水準 (easy/difficult) 設定した。音の持続時間は easy 条件で $200 \mathrm{~ms}$ と $400 \mathrm{~ms}$, difficult 条件で $200 \mathrm{~ms}$ と $260 \mathrm{~ms}$ の組み 合わせで, 長短等確率とした（刺激開始間間隔は 1500 $\mathrm{ms})$ 。両条件とも, 標準刺激 $(p=0.84)$ は $1000 \mathrm{~Hz}$, 逸 脱刺激 $(p=0.16)$ は $1050 \mathrm{~Hz}$ あるいは $950 \mathrm{~Hz}$ であり, 順序はランダムとした。音の周波数の変化は, 課題とは非 関連であり，持続時間の弁別のみに注意するように教示 した。

【記録·分析】 EEG は鼻尖を基準に頭皮上の 30 ヶ所から 導出した (バンドパス 0. 05-100 Hz，サンプリング 500 $\mathrm{Hz}) 。 30 \mathrm{~Hz}$ (6 dB/octave) のハイカット後に, Fp1 を基準 に EOG 補正をした。分析区間は刺激呈示-200 $800 \mathrm{~ms}$ とし, 条件・刺激タイプごとに加算平均を行った。さらに頂 点潜時・振幅を求めるために加算平均波形に対してゼ口 位相ハイカットフィルター $(8 \mathrm{~Hz}, 24 \mathrm{~dB} /$ octave $)$ をかけ た。

\section{結果及び考察}

【行動遂行】両条件において, 逸脱刺激時の RT は標準 刺激時の RT に比べて有意に遅延し (easy 条件 $21 \mathrm{ms,}$ difficult 条件 $42 \mathrm{~ms}$ ）, 課題の難易度に関わらずディストラ クションが生じたことが確認された。さらに，その効果は difficult 条件において有意に増大した。
【ERP】 Figure 1 に各条件での総加算平均（a）及び逸 脱刺激一標準刺激による差波形（b）を示す. MMN 及 び P3a について差波形で分析した結果, 潜時, 振幅とも に条件間で有意な差は見られなかった。一方, P3b の振 幅は easy 条件で標準刺激時に比べ逸脱刺激時で有意に 増大したのに対し, difficult 条件では, 逸脱刺激時の振幅 増大は有意ではなかった。

MMN の結果はこの成分が前注意的処理を反映すると いう知見に一致する。さらに不随意的な逸脱情報処理過 程を反映する P3a の結果においても, 課題の難易度の効 果は認められなかった。したがって, 両条件で前注意的・ 不随意的な逸脱情報処理は同様に駆動したと考えられ る。

difficult 条件では easy 条件に比べて課題遂行により多 くの注意資源が必要である。ゆえに，奪われる注意資源の 量が両条件で同じでも, difficult 条件における課題関連な 情報に対する処理の低下をもたらし,ディストラクション効 果の有意な増大を生じさせたと考えられる。このことは， difficult 条件において標準刺激に比へてて逸脱刺激で P3b 振幅の有意な増大が見られなかったこと，すなわち逸脱 刺激の同定に配分できた注意資源がより少なかったとい う結果からも支持される。

以上のことから，(1) 課題の難易度が高くなるとディス トラクション効果は大きくなる，（2）課題遂行に必要な注 意資源の量に関わらず，逸脱情報に対して不随意的に 奪われる注意資源量は変わらない，（3）ディストラクショ ン効果の大きさは, 課題に必要な注意資源の量によって 影響されること,が明らかになった。 (a)
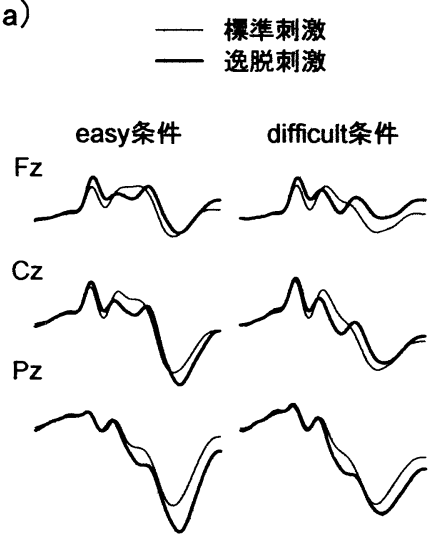

(b)
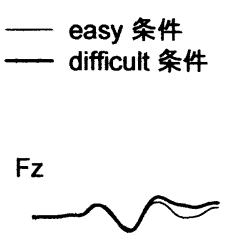

FCz
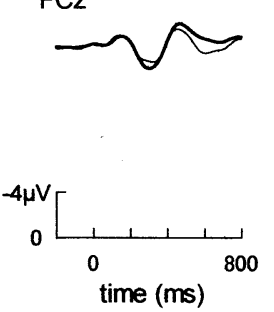

Figure 1. 総加算平均波形 (a) 及び 逸脱刺激一標準刺激による差波形(b) 
刺激文脈による非標的処理の変容 :

非檡的 P3 における非標的/標的類似性効果による検討

○澤木 梨沙（北海道大学大学院教育学研究科, 日本学術振興会特別研究員)

片山 順一 (北海道大学大学院教育学研究科)

標淮，標的，非標的刺激の 3 刺激オドボール課題にお いて，標的／標淮刺激の弁別が容易な刺激文脈では非 標的刺激に $\mathrm{P} 3 \mathrm{~b}$ 様の $\mathrm{P} 300$ が若起されるが，その弁別が 困難な刺激文脈では非標的刺激に P3a が惹起されるこ とが知られている。しかしながら，その背景にある認 知的メカニズムは明らかになっていない。そこで, 本 研究では，刺激文脈が非標的情報処理にどう影響する のかについて，非標的／標的刺激の類似性を操作する ことにより検討した。

\section{方 法}

【被検者】 $20 \sim 30$ 歳の健常大学生・大学院生 13 名 (男 性 6 名・女性 7 名, 平均 23.6 歳) を対象とした。

【課題-剌激-手絓き】課題は 3 刺激オドボール課題 (標隻, 0.70 ; 標的, 0.15 ; 非標的, 0.15 ) とし, 4 条件を標的/標淮刺激の弁別性 (Easy/Difficult) と非 標的/標的刺激の類似性 (similar/dissimilar)の組み 合わせで設定した。全課題条件で標的刺激は小さな青 色の円 $\left(1.15^{\circ}\right)$ とした。Easy 課題の標準刺激は大きな 青色の円 $\left(2.30^{\circ}\right)$, Difficult 課題の標淮刺激は小さな 青色の円 $\left(1.30^{\circ}\right)$ とした。各課題における similar 条件 の非標的刺激は小さな青色の四角 $\left(1.00^{\circ}\right)$, dissimilar 条件の非標的刺激は大きな赤色の四角 $\left(2.00^{\circ}\right)$ とした。 4 条件の実施順序は被験者ごとに変えた。

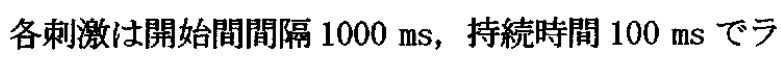
ンダム順に呈示した。刺激系列中, 標的刺激の出現に 対してできるだけ速く正確に, 右手親指でボタン押し することを課題とした。

【記録·処理】EEG は鼻尖を基準とし, 頭皮上 30 電極 から導出した。信号は 0.01〜 $30 \mathrm{~Hz}$ のバンドパスで増 幅後, $250 \mathrm{~Hz}$ で A/D 変換した。刺激呈示前 $100 \mathrm{~ms}$ を 含む $900 \mathrm{~ms}$ 間を刺激タイプ毎に加算平均した。標的刺 激に対する $\mathrm{ERP}$ では $\mathrm{Pz}$ 部位で, 非標的刺激に対する $\mathrm{ERP}$ では $\mathrm{Cz}$ 部位で, 刺激呈示後 $300 \sim 700 \mathrm{~ms}$ 間での最 大陽性点をそれぞれの標的 $\mathrm{P} 3$ 頂点, 非標的 $\mathrm{P} 3$ 頂点と し, 潜時及びこの潜時での正中線上 5 電極部位 $(\mathrm{Fz}, \mathrm{FCz}$, $\mathrm{Cz}, \mathrm{CPz}, \mathrm{Pz}$ )における振幅を求めた。

\section{結果及び考察}

【行動指㩰】行動指標の結果から, Difficult 課題に おける有意な RT の延長 $(p<.001)$, Hit 率の低下 $(p$ $<.001)$, 標隻刺激に対する FP の増大 $(p<.01)$ が示さ れ，標的/標淮刺激の弁別性は適切に操作されたこと が確認された。非標的刺激に対する FPは, Difficult 課題では条件間に有意な差はみられなかったが, Easy 課題では similar 条件で有意に増大した $(p<.02)$ 。

【ERP】Fig. 1 に総加算平均 ERP 波形を示す。Easy 課 題では非標的に non-target P3 が惹起され, その振幅 は similar 条件で増大した $(p<.06)$ 。さらに, similar 条件において FP が増大したことからも, Easy 課題に おいて非標的刺激は課題関連情報として処理されたこ とが示唆された。一方, Difficult 課題では非標的に P3a が惹起され，その振幅は dissimilar 条件で増大し た $(p<.001)$ 。このことから, Difficult 課題におい て非標的刺激はディストラクター情報として処理され たことが示唆された。

標的検出への注意的構えは, 標淮刺激系列からの標 的検出が容易な Easy 課題では “標準刺激からの逸脱” 一と向けられ，その検出が困難な Difficult 課題では “標準/標的刺激間の厳密な弁別” へと向けられると 考えられる。その結果, 注意的構えと一致する Easy 課題の非標的刺激は課題関連情報として処理され，一 致しないDifficult 課題はディストラクター情報とし て処理されたと考えられる。以上のことから，標的／ 標淮刺激の弁別性の高/低が標的検出一の注意的構え に影響し，それにより非標的刺激が課題関連情報とし て処理されるか, 又はディストラクター情報として処 理されるかの変容が生じることが明らかとなった。

Easy

Difficult

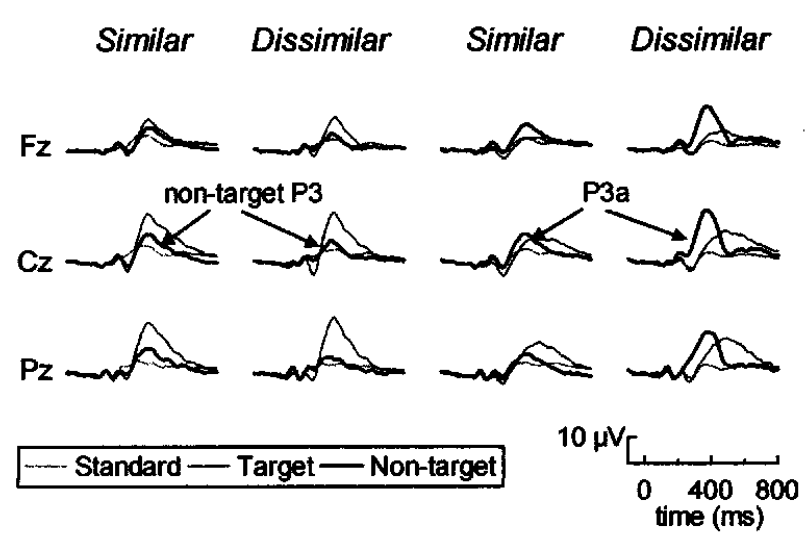

Fig. 1. 各裸题条件での総加算平均 ERP 波形 
課題切り替えが顔イメージ記憶探索と反応選択に及ほ す影響

○梅林 㙵(愛知䟢德大学コミュニケーション研究科)

沖田席禽(受知频德大学コミュニケーション学部)

【問題と目的】

課題を切り替える際に，その認知的制御過程を反映 するものとして切り替えコスト (Switch cost : 反応時 間の延長)が生じる。本実験は, 手がかり呈示による予 期的切り替え事態で記憶探索課題を遂行させながら， 顔イメージ同定関連の刺激セット切り替えと反応選択 関連の反応セット切り替えを要請した。Meiran(2000) は, 刺激セット切り替え操作は予期的な切り替えが可 能であるが, 反応セット切り替え操作は先行セットが 自動的に干渉するというモデルを提唱している。本報 告は行動指標に加え, 各処理過程と対応する ERP 潜時 として, 符号化過程は $\mathrm{N} 1$, 刺激評価過程 (刺激入力か ら記憶照合完了)は P3, 反応実行過程は反応ロック -LRP を採用し, 刺激評価過程と反応出力過程を時間的 に検討, 反応時間切り替えコストに関わる処理過程を 同定する。

\section{【方法】}

実験参加者 12 名の右手利き大学院生 (女 11 名, 男 1 名: $26.4 \pm 5.2$ 歳)。整激 未知の男性顔, 女性顔のグ レースケール写真 (視角 約 $\left.5.5^{\circ} \times 5.5^{\circ}\right)$ 各 20 枚。課題 と手続き 実験参加者は試行ブロックの最初に記憶 セット(標的)刺激として男女合わせて 3 名の顔イメー ジを記銘した後, 検査刺激として男男女女と 2 回ずつ 交互に 1 名の顔写真の呈示を受けた。課題は検查刺激 中から標的を検出し，さらに男女の標的に対し異なる 手で反応する(例 : 男の標的は右, 非標的は左; 女の標 的は左, 非標的は右)ことであった。標的刺激の呈示に 時間制御はなく, 記銘後に参加者自らのボタン押しに よって検查項目の呈示が始まった。1 試行は(1)手がか り刺激 $1 \mathrm{~s}$ 間呈示(「男/女」), (2検査項目 $0.2 \mathrm{~s}$ 間呈 示, (3)反応後, 試行間間隔 $1 \mathrm{~s}$ (1 ブロック 44 試行, 合 計 8 ブロック)であった。 $\mathrm{ERP}$ 記録・解析 両耳桑を基 準電極とし， F3・F4・C' 3・C' $4 \cdot 01 \cdot 02 \cdot \mathrm{F} 7 \cdot \mathrm{F} 8 \cdot$ $\mathrm{T} 3 \cdot \mathrm{T} 4 \cdot \mathrm{T} 5 \cdot \mathrm{T} 6 \cdot \mathrm{Fpz} \cdot \mathrm{Fz} \cdot \mathrm{Cz} \cdot \mathrm{Pz} \cdot \mathrm{E} 0 \mathrm{G}$ で記録, 記憶 セットサイズ $(\mathrm{M} 1, \mathrm{M} 2)$, 切り替え (Sw, Re), 標的 (Tgt,N-Tgt)の 8 カテゴリに分けて加算処理された。統 計的検定は上記カテゴリ $2 \times 2 \times 2$ の 3 要因反復測度 ANOVA, N1 成分については記録部位(T5,T6)の要因も含
め, 4 要因反復測度 ANOVA が行われた。

【結果と考察】

行動指標 正反応の反応時間(Table 1)において, 記 憶セットサイズメ切り替えメ標的の交互作用が認め られた $(p<.01)$ 。続く単純・単純主効果の結果は,すべ てにおいて有意であったが(いずれも $p<.05)$ ，切り替 えに関わる単純交互作用として非標的における記憶セ ットサイズメ切り替え(p<.001)の効果がみられた。

ERP 検查刺激呈示後, 後側頭部の潜時約 $160 \mathrm{~ms}$ に陰 性成分 $\mathrm{N} 1$ が惹起,これは顔の符号化処理に関わる電位 とみなされる。続く記憶照合を含む刺激評価完了は $\mathrm{Pz}$ のP3 潜時で測定した (Table 2)。統計的検定の結果, N1，P3 潜時ともに切り替え効果は認められなかった。 しかし, P3 潜時では記憶サイズと標的の主効果が有意 で(記憶サイズ: $p<.05 ;$ 標的: p<.001)，M2(619 ms) はM1 (583 ms)よりも，また非標的(630 ms)は標的(573 ms)よりも P3 潜時の延長を認めた。反応実行開始の指 標となる LRP 立ち上がり潜時では，切り替え効果はみ られなかった。

以上のように，行動指標において切り替えコストが 生じ, 他方, ERP 各成分の潜時に切り替えに伴う延長 は認められなかった。切り替えコストが記憶照合過程 にあるのであれば, 記憶セット増加に伴う切り替えコ ストの増加として，記憶セットメ切り替えの交互作用 が認められると予測されるが(Sternberg, 1966)，少な くとも標的条件においてはこの効果が認められなかっ た。加えて N1，P3の ERP 潜時も延長しないことから， 刺激評価に関わる刺激課題セットは手がかり呈示によ って事前的な切り替えが可能であったことが示唆され る。さらに,反応実行過程が延長しなかったことから， 刺激評価と反応実行の間に介在する反応選択過程で反 応セット切り替えが予期的に(少なくとも完全には)実 行できず，反応時間に反映される切り替えコストとし て残ってきたと推察できる。

Table 1.各条件の平均反応時間

\begin{tabular}{llllll}
\hline & & Target & & \multicolumn{2}{c}{ Non-Target } \\
\hline & & M1 & M2 & M1 & M2 \\
\hline \multirow{2}{*}{ RT (ms) } & Switch & 586 & 685 & 673 & 734 \\
& Repetition & 537 & 614 & 568 & 684 \\
\hline
\end{tabular}

Table 2.各条件の P3 潜時

\begin{tabular}{ccclc}
\hline & \multicolumn{2}{c}{ Target } & \multicolumn{2}{c}{ Non-Target } \\
\hline & M1 & M2 & M1 & M2 \\
\hline Latency (ms) Switch & 547 & 592 & 629 & 640 \\
Repetition & 559 & 593 & 598 & 653 \\
\hline
\end{tabular}




\section{大䏚各半球で顔イメージ記憶を 同時並列的に探索可能か?}

\section{事象関連脳電位を用いた検討}

\section{○沖田 庸嵩 （愛知淑徳大学・エシューケーション学部）}

安田 恭子（愛知淑德大学大学院・エミエニケーショコン研究科）

\section{目的}

人の顔を刺激として Sternberg 型記憶探索時の ERP を記録すると, 後側頭部で $\mathrm{N} 170$ 頂点後の $200 \mathrm{~ms}$ あたりから探索関連陰性電位 (SN) が観察された（沖 田ほか, 2002).さらに, 検查刺激を左右視野のいず れかに提示すると，SN は刺激提示視野と同側の記録 部位と比べ反対側では約 $50 \mathrm{~ms}$ 早く始まり，その終 了は左右部位 (T5/T6) 間で变わらなかった（沖田・ 小西, 2005). 刺激提示視野に応じた大脳半球間の異 なる後側頭部 ERP 応答は, 作業記憶探索に要請され る記憶表象が各大脳半球後側頭部に保持され，挆索 操作が独立並列的に実行されることを示唆する. 作 業記憶探索が左右各大脳半球で独立並列的に実行さ れるものかどうか，それを探る予備的な検討をとく に後側頭部 ERP の振舞いから試みた.

$$
\text { 方 法 }
$$

【実験参加者】視力正常な学生 12 名（21-38 歳).

【刺激と課題】人の顔写真（未知の男女各 22 人）を 使用し，女性の顔は実験を通して常にディスプレィ 中央の凝視点の左側に, 男性は右側に呈示した。各 試行系列の最初に標的として, F2M1 系列では女性 2

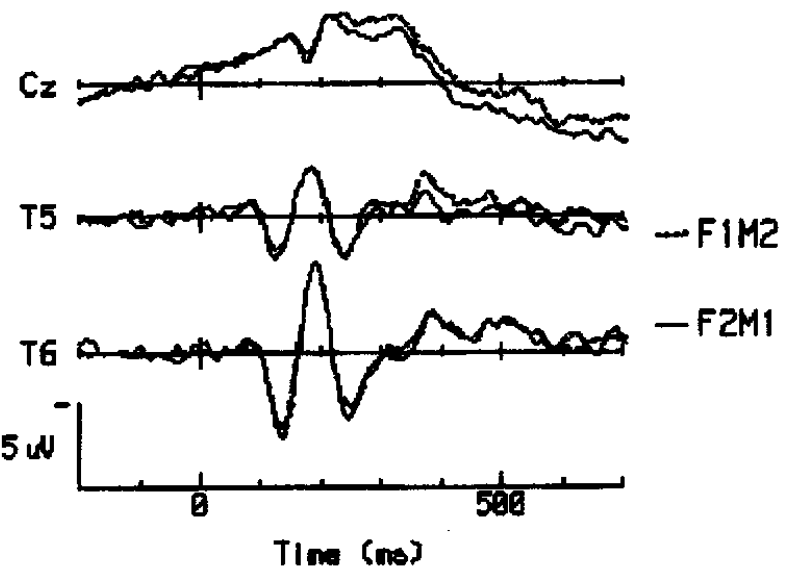

Figure 1 F1M2 と F2M1 系列で $\mathrm{Cz}$ ・T5・T6 部位から 記録された非標的刺激に対する ERP.
人と男性 1 人, F1M2 系列では女性 1 人男性 2 人の顔 写真を $10 \mathrm{~s}$ 間呈示して参加者に記銘させた。 $1 \mathrm{~s}$ 後 に，検查刺激として男女 1 人ずつ対にして同時に $200 \mathrm{~ms}$ 間次々と SOA $1 \mathrm{~s}$ で呈示した. 参加者の課題 は標的を検出しボタン押し反応を行うことであった。 刺激は凝視点から左右に視角で $2.3^{\circ}$ 離れた位置に $3.4^{\circ} \times 4.3^{\circ}$ の大きさで呈示した.これらの検查刺激 は系列あたり 26 試行, その最初の 2 試行はダミー, 残り 24 試行のうち非標的が 20 試行, 標的が 4 試行 であった.

【手続き】課題練習後, 各参加者はF2M1 と FIM2 系 列を合わせて $12-22$ 回受けた.

【記録】 EEG は頭皮上 19 部位から鼻尖を基淮として 導出した $(0.05-30 \mathrm{~Hz})$. 同時に水平 $\mathrm{EOG}$ も監視した.

\section{結 果 と考 察}

非標的刺激に対する ERPはT5に比べT6 で大きな N170 が生じた (Figure 1 参照). 先の研究と同様, 刺激後 $250 \mathrm{~ms}$ あたりから SN の発達がみられる。も 乙顔刺激呈示視野と対側半球で，すなわち女性顔は 右半球で, 男性顔は左半球でそれぞれ記憶探索が独 立して実行されるとすれば, F2M1 系列では右半球で 2 つ, 左半球で 1 つの顔照合が要請されるので, $\mathrm{T} 5$ よりT6部位で大きな SNの発達が予測された.また, F1M2 系列ではその逆が予測された. 300-600 ms 区間 平均電位 (Figure 2 参照) に基づく分析で予測どお $り$, 系列 $\times$ 部位の交互作用が得られたが $(p=.014)$, F1M2 系列では T5・T6 間に差異は見出せなかった. 本結果は部分的に並列的な記憶探索を示すとともに, 左右半球における記憶表象や探索様式の相違を示唆 している.

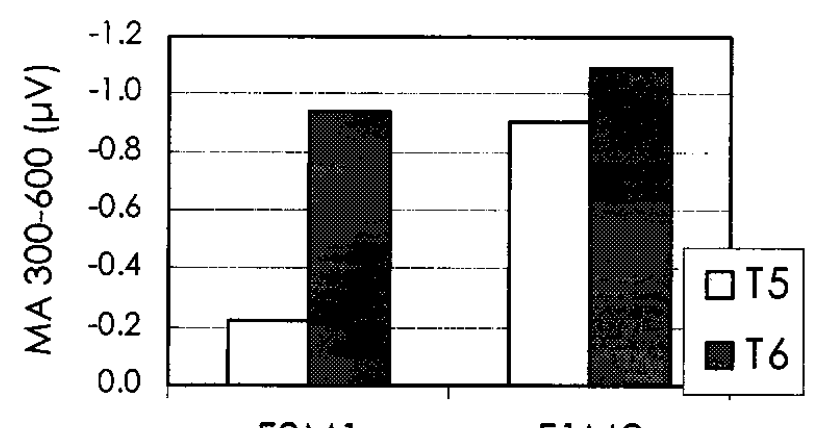

F2M1

F1M2

Figure 2 FIM2 と F2M1 系列における T5・T6 部位 の刺激後 300-600 ms 区間平均電位. 


\section{顔の可愛らしさに関わる事象関連電位の検討}

岩城 達也 (広島国際大学心理科学部)

\section{1.はじめに}

Lorenz (1943) は人や動物の幼児がもつ幼体図式 (頭 部比率, 眼の大きさと位置, 顎の形状など）が鍵刺激 となり，大人に幼児を可愛らしいと判断させ，保護し たいといら欲求を解発させると提唱した。動物行動学 的観察から得られたベイビネスが実際に保護欲求を惹 起するか検証することで，人間における鍵刺激一欲求 発現の関係を定式化するアプローチになると考えられ る。

そこで, 本研究では今回は, 顔についての研究デー タが豊富であることから，可愛らしさの中でも顔の可 愛らしさを取り上げた。眼の大きさを操作することで 顔の可愛らしさを変化させ, こうした刺激に伴う事象 関連電位（ERP s）の検討を試みた。

2. 方法

実験参加者：19 名の大学生を対象とした。実験参加 者は，全て右利き手で視覚的な障害はなかった。

画像刺激 : イヌの顔写真画像（グレースケール）に ついて眼の形状を維持したまま, サイズ比率を変化さ せた画像を 7 つ用意した。

実験手続き: コンピュータディスプレイに刺激画像 を $800 \mathrm{~ms}$ 呈示した。 1 試行に 2 枚の画像を連続提示し, 1 枚目を見本として 2 枚目の標的刺激が 1 枚目に比心゙ て可愛いかどうか判断させた。判断は机上に設置され

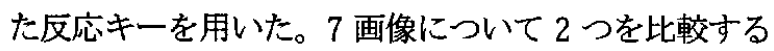
組み合わせは49組であり,これを6回繰り返したため, 総試行数は 294 回であった。画像の呈示順序はランダ ムにした。

脳波及び眼球運動記録： $\mathrm{Cz}$ を基準として頭皮上 21 部位から脳波を導出した。帯域通過周波数 $0.03-$ $100 \mathrm{~Hz}$ で増幅し，サンプリング周波数 $500 \mathrm{~Hz}$ で $\mathrm{A} / \mathrm{D}$ 変 換し記録した。記録後, 両耳架の平均電位で再基準化 した。刺激に同期して画像呈示前の $100 \mathrm{~ms}$ から, 刺激 後 $1000 \mathrm{~ms}$ を分析区閒として加算平均処理を行い, 事象 関連電位を得た。今回の分析では，1）見本画像と標的 画像に伴う ERP の比較，2）選択反応データをもとに した見本画像におうる可愛い画像と可愛くない画像の 比較及び3）標的画像に対する可愛らしさ判断により ERPを比較した。
3. 結果と考察
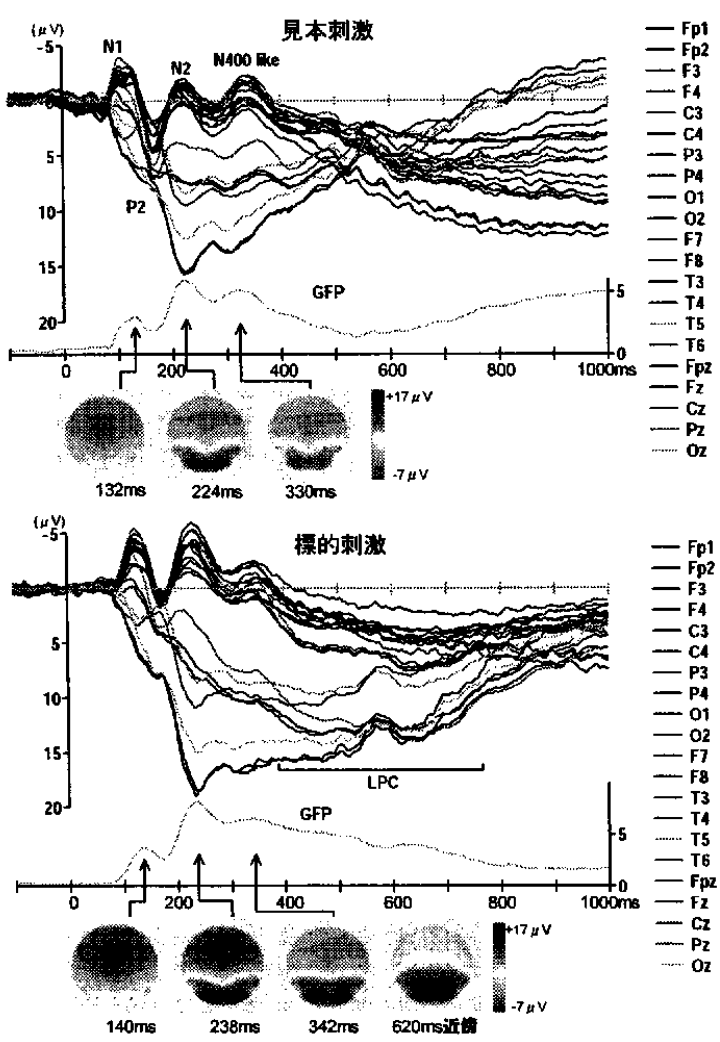

Figure 1. 見本刺激と標的刺激に伴う ERPs

まず，見本画像に伴う ERP 波形加ら $\mathrm{N} 1 ， \mathrm{P} 2$ ，N2，及 び $\mathrm{N} 400$ 成分が確認できた。標的画像では, 見本画像で みられた成分のうち $\mathrm{N} 2$ 成分の振幅が上昇した。加えて, 後期陽性成分 (LPC) が出現した。こうしたN2 及び LPC が可愛らしさ判断に関連するとも考えられたが，課題 特性の違いを反映している可能性があった。

そこで，見本画像における画像別 ERP 波形及び標的 画像における反応選択別 ERP 波形の比較を行った。そ れぞれの ERP 波形に共通する顕著な成分として, $500 \mathrm{~ms}$ 近傍の成分と LPC が挙げられた。 $500 \mathrm{~ms}$ 近傍の成分は 画像が可愛らしくない場合に振幅が高かった。LPC は 画像が可愛らしい場合に振幅が高かった。N2成分につ いては，可愛らしさに関わる顕著な変化は認められな かった。

これらのことから，見本刺激と標的刺激を比較した 際にみられた N2 成分の振幅の上昇は, 課題特性の違い を反映している可能性が高いと考えられた。一方で, 比較的潜時の長い成分が可愛らしさ，もしくは可愛ら しくないとの判断に関与していると推測された。 
顔画像の表情変化・人物変化に対する事象関道䋞雷位

○風井 浩志 (関西学院大学大学院文学研究科)

本竜 㤵 (関西学院大学文学部)

永井 聖剛 (産菜技術総合研究所)

八木 昭宏 (関西学院大学文学部)

\section{1. 序}

顔画像刺激に対して特異的に惹起される事象関連脳 電位 (event-related potential, ERP) の成分として 頂点潜時が約 $170 \mathrm{~ms}$ の陰性成分（N170）が知られてい る。近年, 表情の変化の違いが N170 に反映されるとい うことが, Miyoshi, Katayama, and Morotomi (2004) に よって報告された。本研究では，Miyoshi et al.の実 験に做って，連続して呈示される2つの顔画像刺激の 間で表情と人物を変化させたときの ERP を計測した。

2. 方法

被験者 $20 \sim 34$ 歳の 12 名（男 6 名, 女 6 名）が害 験に参加した。矯正後も含めて，全員が健常な視力を 有した。

刺激 17 インチCRTディスプレイの中央に縌 $5.4 \mathrm{~cm}$ $\mathrm{x}$ 横 $3.7 \mathrm{~cm}$ の棈円形にくりぬかれた顔写真をグレイス ケール (255 階調) で呈示した。ディスプレイまでの 観察距離は $120 \mathrm{~cm}$ であった。20 名のモデルが, Ekman （1975）の表情分類に基づいて作った表情 (真顔, 笑顔, 怒顔)を撮影した画像の合計 60 枚を顔刺激として用い た。いずれの画像も平均輝度は $25 \mathrm{~cd} / \mathrm{m} 2$ であった。

手続き 被験者は暗室の中で着席した状態で課題を 遂行した。ビープ音が呈示されてから $350 \mathrm{~ms}$ 後に画面 中央に第 1 刺激として, 60 枚の中の 1 枚の画像が呈示 された。第 1 刺激の呈示時間は $750 \mathrm{~ms}$ であった。第 1 刺激に引き続いて第 2 刺激が呈示された。第 2 刺激も 60 枚の画像の中の 1 枚であった。被験者には，「第 2 刺激が第 1 刺激と同一人物であり，かつ表情が異なる」 ならば所定の反応キーを押すこと，「第 2 刺激が第 1 刺激と異なる人物であり，かつ表情が同一である」な らば別の反応キ一を押すこと，が求められた。第 1 刺 激と第 2 刺激との間での表情の組み合わせと，第 1 刺 激と第 2 刺激との間での人物の一致・不一致の組み合 わせによって，何も変化しない条件も含めて合計 16 条件が設定された。被験者は, 57 試行から成るブロッ クを 25 ブロック以上遂行した。条件の順序は実験を通 してランダムな順序であった。
記録 EEG は鼻尖を基準として, Fz， Cz，Pz，Oz， T5，T6 の 6 部位から導出し、眼電位（EOG）は水平方 向眼球運動の検出のために両眼眼裂外加 , 垂直方向 眼球運動/瞬目の検出のために右眼眼窝上縁部と下眼 瞼から双極導出した。これらの生体信号を、時定数 2.0 秒，高域遮断周波数 $100 \mathrm{~Hz}$ 、サンプリング周波数 1000 $\mathrm{Hz}$ で記録した。

分析 刺激呈示後 $140 \mathrm{~ms}$ 後から $200 \mathrm{~ms}$ 後までの間 で最も振幅の大きな時点を N170 成分の頂点潜時とし た。頂点振幅と頂点潜時の被験者間平均に対して，条 件（16 水準）と部位（T5/T6 の 2 水準）を要因とする 分散分析を行った。下位検定として, ニューマン・クー ルズ検定を行った $(\alpha=.05)$ 。

\section{3. 結果および考察}

第 1 刺激 (真顔，怒顔，笑顔）に対するN170に関し て，3つの表情の間で惹起された $\mathrm{N170}$ の振幅や頂点 潜時には統計的に有意な差は認められなかった。 Figure 1 に, 表情のみが変化した第 2 刺激に対するERP （導出部位：T5）の例を示す。分析の結果，振幅に対 する条件の効果のみが認められた $(\mathrm{F}(18,198)=7.83$, $\mathrm{P}<.01)$ ，下位検定の結果，「同一人物内の真顔から 笑顔への変化によって惹起された 170 は他のいずれ の条件の N170 よりも振幅が有意に大きいことが示さ れた。この結果は, N170が生起する段階以前で，表情 の認知処理が行われていることを示唆する。

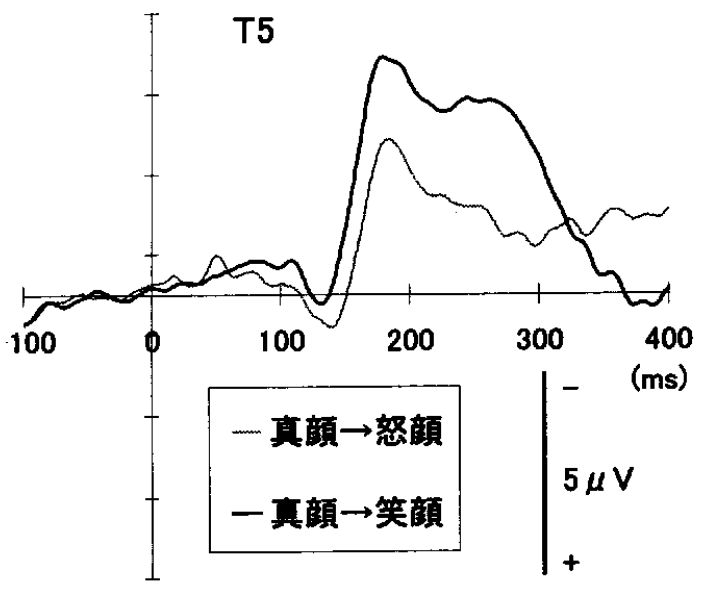

Figure 1. 第 2 刺激に対する ERP の例。真顔から怒顔 に変化した条件の ERP と，真顔から笑顔に変化した条 件の ERP。導出部位 : $T 5, \mathrm{~N}=12$ 。

之現所属: 関西学院大学理工学研究科ヒューマンメ ディア研究センター。 


\section{そろばん就達者の計算スキルと脳活動}

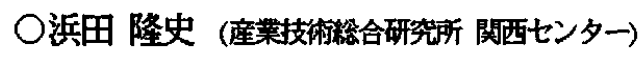

\section{1 はじめに}

そろばんを用いた計算では，数を数字という記号で はなく珠の空間的配置で表現する。さらにそろはん熟 達者では，手を動かさずに高速に暗算できる。心理 学的研究によると, そろはん熟達者の暗算能力は空間 的な同時タスクに干渉されるが言語的な同時タスクに は干涉されない。そこで彼等の暗算能力は空間視機能 によると示唆された (Hatano G and Osawa K, Cognition,

15，1983)。じっさい彼らが暗算中に, 空間視を司る 右頭頂葉が特異的に活動する (Hanakawa $\mathrm{T}$ et al, Neurolmage，19，2003)。しかしここの暗算能力およ びその神経過程の時間特性は不明である。そこで当研 究では，そろばん熟達者が数表を上から下に眼で追い ながら加算するときの眼球運動をもとに暗算の時間特 性を推定した。さらに腮活動の時間経過を脑磁計で調 へた。

\section{2 方法}

日本珠算連盟 9 段の熟達者 $(\mathrm{n}=1)$ を被験者とした。ま す数字を順々にフラッシュ的に提示する方法を考えた がっこ被験者にとって十分に速く提示できなかった。 そこで 3 桁の数字 (視角 $1.5^{\circ}$ ) が 2 空行を挟んで縦 に 12 列ならべられた表を上から下に眼をサッケード させつつ数の総和を計算した。コントロールとして， 同じ表を上から下に眼を移動させて奇数の個数を数え た。サッケード終了のタイミングで脳磁波を加算平均 して誘発波を求め, タイポール法および MCE 法 (minimum current estimate method, Uutela $\mathrm{K}$ et al, NeuroImage, 10，1999)で信号源推定を行った。

\section{3 結果}

眼球運動では、下向きサッケードと固視がしばしば 規則的に絽り返した。サッケードの平均持続は $93 \mathrm{~ms}$ で, 1 行を固視する平均時間は 199ms だったので, この $199 \mathrm{~ms}$ の間に視覚入力・加算・メモリへのストア という 1 連の過程が行われると考えられる。サッケ一 ト終了後 $55 \mathrm{~ms}$ に右下の後頭側頭葉に, そして $113 \mathrm{~ms}$ に後頭葉正中部にそれそれ1個のダイポールが推定さ

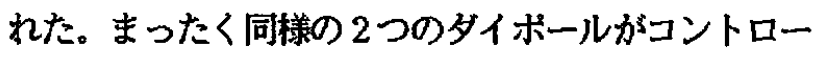

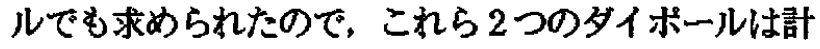
算自体とは無関係な視覚過程, おそらくサッケードに 伴う網膜像の動きへの反応だと考えられる。MCE 法 によると,上記のタイポールに対応する活動に加えて, 潜時 $125 \mathrm{~ms}$ と $256 \mathrm{~ms}(-16 \mathrm{~ms})$ で右の上頭頂葉に活動が 見つかった (Figure 1)。コントロールでは右上頭頂 菓の活動を見いだせなかった。

\section{4 竓諞}

そろばん熟達者では加算の 1 過程が約 $200 \mathrm{~ms}$ で行 われると考えられる。またその期間中に 2 回, 右の上 頭頂葉に活動が推定された。それぞれ計算の始まりと 終わりをコードすると考えられる。右上頭頂葉の活動 は、そろばん熟達者での暗算が㽞語的・直列的ではな く空間的・並列的な処理によるとの推察と一致する。 ものづくり作業（ex.レンズ磨き、きさげ作業）やス ポーツは、眼と手の協調や空間視機能が重要だという 点で、そろばんを用いた計算と似ている。熟達した段 階でのこれらの能力は、スキル（狭義）と呼ばれる。 もし当研究結果を拡大解釈できるならば、眼と手の協 調機能と空間視機能が、熟達を通して右頭頂葉に内的 に（外の世界とは独立に）表現されるようになること がスキルの神経基盤ではないかと考えられる。なお今 後は被験者数を増やす必要がある。

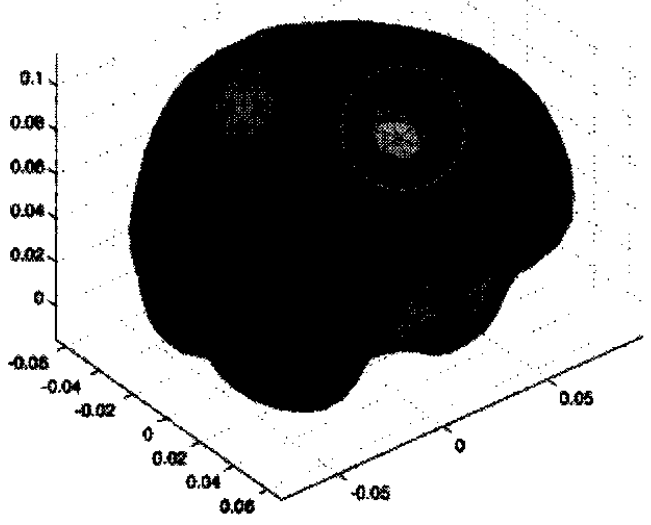

Figure 1 脳を右後から見た MCE 推定結果 $(\mathrm{t}=-16 \mathrm{~ms})$ 。 ○で囲んだところが, 右上頭頂葉の活動。

謝辞 被験者の MW 氏の積極的な寄与に感酎します。 


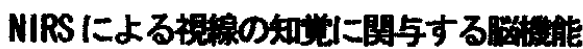

玉木 宗久 (独立行政法人国立特殊教育絵合研究㠼)

\section{1. 研究の目的}

視線の知覚は, 自閉症やアスペルガー障害のある人の 社会性障害や教育的対応を探るための重要な指標であり， 人の社会性の発達にとって重要な意味をもっている。

近年, このような視線の知覚に関与する脳機能が, = ユーロイメージング法を用いたいくつかの研究により明 らがされつつある。fMR を用いた先行研究 (Pelphrey， et a1., 2003）によると，他者の視線シフト（ある対象 に対して視線をシフトする）の知覚は，上側頭溝

(Superior temporal sulcus: STS) 領域の右半球側の賦 活と関係するようである。また, STS の賦活は, 対象と視 線の向きとの関係 (一致, 不一致) などの文脈によって も変化するようである。

本研究では, 近赤外分光法 (near-infrared spectroscopy：NIRS）により，このような視線の知覚に 関与する脳機能を検討した。

\section{2. 方法}

参加者：右利きの健常成人 6 名が本研究に参加した (男性 4名，女性 2 名; 年踚 $M 48.0 \pm S D=14.11$ 才; 年齢籍囲 34-65才)。参加者には, 研究の目的, 実験 の内容を十分に説明し，実験参加への同意を得た。

実酸デザインと手続き：視線を表すために, Matsumto \& Ekman (1988) により開発されたニュートラルフェイス (JACneuF）から日本人男性 1名の顔写真を選択し，頭部 のみ表示されるように縁を切りとり，グレースクールで デジタル化した。

各トライアルにおいては，顔写真の左右の位置（目の 高さ）のいずれかに参加者が選択したイラストを $5 \mathrm{sec}$ 提示した。イラストに対する視線を操作して 3 つの条件 を構成した：(a) 視線シフト一致条件，(b)不一致条件， (c)シフト無し条件。一致条件では，視線をイラストに向 けシフトさせ，不一致条件では，視線をイラストと反対 方向にシフトさせた。シフト無し条件では，視線を固定 した。視線シフトの 2 つの条件においては，イラストを 提示した $1 \mathrm{sec}$ 後に視線をシフトし，4 sec それを維持し た。各トライアルは, $17 \mathrm{sec}$ のインターバルをとり，そ の間は，顔写真のみを提示した。刺敫は，E-primeにより 操作し, ディスプレイに提示した。実験中，参加者は， リクライニングチェアに座り, ディスプレイを見て, 顔
写真の視線がシフトしたときに右手の親指でボタン押し をするように教示した。実験では，24トライアルからな る 4 セッションを行った（各条件 32 トライアル）。セッ ション間では，必要に応じて休顋をとった。

NIRSによる計社 ： 上記のような課題遂行中に，光卜 ポグラフィシステム（ETG-4000; Hitachi Medical Corporation, Tokyo, Japan) を利用して, 酸化へモグロ ビン量の変化 $(0 \mathrm{xy}-\mathrm{Hb})$ を計測した. NIRS の信号は，左 右半球の各側崸領域 $(6 \times 12 \mathrm{~cm})$ に $3 \mathrm{~cm}$ 間隔で 15 本の 光ファイバーを配置し,それぞれの光ファイバー間の 44 チャンネル (h) から検出した. 光ファイバーの配置は, Okamoto，et al.（2004）の国際10-20 法による皮質領域 と対応を参照した.

データ分析：各トライアルにおける視線に対する反

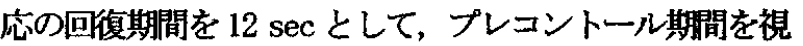
線シフト前 $5 \mathrm{sec}$ ，ポストコントロール期間を回復期間後 $5 \mathrm{sec}$ とした。プレ/ポストコントロール期間の NIRS 信 号の摇らぎを調整して，それそれれの条件で28～32 トライ アル分の $0 \mathrm{xy}-\mathrm{Hb}$ データをCh ごとに加算平均した。

\section{3. 結果・考察}

参加者個々人の加算平均 $0 \mathrm{xy}-\mathrm{Hb}$ をさらに加算平均して, 総加算平均 $0 x y-H b$ とした。それによると, 側顗の後方領 域において視線シフトに同期した右半球優位の賦活が認 められた。最も賦活の大きかった視線シフト後 $5 \sim 10 \mathrm{sec}$ の $0 \mathrm{xy}-\mathrm{Hb}$ 総和量を左右のCh で比较した結果, STS 領域に 位置すると考えられる 3 つの部位で統計的に有意な左右 差が認められた（的く.05）。

この右側の 3 つのチャンネルについて各条件の $0 x y+t b$ を比較した。いずれの条件においても視線シフト後に Oxy-Hb の増加が誌められたが，その増加量は，一致条件 よりも不一致条件で統計的に有意に大きかった（ $\propto .05 ） 。$ このことは，先行研究で述べられているように，視線知 覚により右半球の STS 窴域か賦活され，またそれは何ら かの文脈により影響を受けることを示唆している。

一方, 今回の研究では，一致条件と同様の $0 \mathrm{xy}+\mathrm{Hb}$ の增 加がシフト無し条件においても認められた。ただし， Oxy-Hb のピーク潜時は，2 つの視線シフト条件よりもシ フト無し条件で長い傾向があった（メ.10）。これらのこ とは, 今回得られた右半球優位の反応が単なる運動の知 覚によるものではなく，また，STS 窅域は，視線シフトの 知覚だけでなく，視線に対する予期など他の認知過程も 反映している可能性があることを示晙している。 


\section{NIRS からみた単音節語音による言語半球優位性}

○内田絢子（茨城県立結城養護学校）

勝二 博亮 (茨城大学教育学部)

尾崎 久記 (茨城大学教育学部)

\section{I . 目的}

本研究では、両耳分離モニタリング検査 (DMT) 遂行中 に, Broca 野周辺で $0 \mathrm{xy}-\mathrm{Hb}$ の増加が NIRS で捉えられ るかを検討した。また，同じ刺激を両耳に同時呈示す る Binaural 条件と DMT 条件を比較し, 頭頂・側頭領域 の両耳分離聴に関わる脳活動を検討した。

\section{II. 方法}

1. 対象者：健常右利き成人 17 名（男性5名, 女性 12 名）。2. 刺激音と刺激呈示：語頭が破裂音からな る持続時間 $200 \mathrm{~ms}$ の $\mathrm{CV}$ 音 $(/ \mathrm{ba} /, / \mathrm{ga} /, / \mathrm{ka} /, / \mathrm{ta} /)$ 。 刺激の立ち上がりと立ち下がりに $20 \mathrm{~ms}$ のコサインテ 一パリング処理。刺激呈示装置（STIM：NeuroScan 社 製) で作られた刺激音はオージオメーターを介し， ッドフォンから左右耳にそれぞれ平均聴力上 $40 \mathrm{dBSL}$, ISI $2.3 \mathrm{~s}$ で呈示。左右耳にそれぞれ異なる単音を組 み合わせたDichotic 刺激対と, 同じ単音を組み合わせ たBinaural 刺激対について,ターゲット音の/ $\mathrm{ka} /$ ダ呈 示された際に，右拇指ですばやくボタン押しするよう 対象者に要求。3. NIRS 記録: 国際 10-20 法の C3・C4 をそれぞれ中心とする左右半球各 12 部位からサンプ リング間隔 $100 \mathrm{~ms}$ で脳血流を記録。タスク区間 (T) を 30 秒，レスト区間 $(\mathrm{R})$ を 30 秒とし，1ブロックにタス クが 2 試行含まれる R - T - R - T - R のブロックデザイ ンを適用。課題は，TをBinaural 刺激， $\mathrm{R}$ を安静状態 とする BR 課題, $\mathrm{T}$ をDichotic 刺激, $\mathrm{R}$ を安静状態とす るDR 課題, $\mathrm{T}$ をDichotic 刺激, R B B naural 刺激と する DB 課題で, 各課題 2 ブロックずつ実施。4. 実験 手続き：課題実施順序は対象者間でカウンターバラン ス。NIRS 測定に先立って, 純音聴力検查, 単耳聴検査 を実施。5.分析：DMT が実施された DR および DB 課 題について，対象者ごとに左右耳別の正答率，反応時 間を算出。大脳半球優位性の指標であるラテラリティ 指数 (Laterality Index：LI)を下記式より算出。

(右耳の正当数) - (左耳の正当数)

$\mathrm{LI}=\longrightarrow \times 100$

(右耳の正当数 $)+($ 左耳の正当数 $)$
NIRS は全 17 名中, 記録状態の悪い 2 名, DMT で左耳優 位を示した 3 名を除く計 12 名を分析。タスク開始前の 10 秒間 (Pre time) と，タスク終了後 20～30 秒の 10 秒 間 (Post time)をベースラインとし，各課題とも計 4 試行について加算平均し, Grand Average 波形を算出。

\section{III. 結果及び考察}

1.DMTからみた言語半球優位性 : 全対象者中 12 名が 右耳優位，3名が左耳優位であった。右耳優位者と左 耳優位者の出現比率の差についてカイ二乗検定を実施 したところ有意差が認められた $\left(\chi^{2}(1)=10.706\right.$ ， $\mathrm{p}<.05$ )。先行研究と同様, 多<の対象者で右耳優位 (左 半球優位) が認められたことから, 本研究で実施された DMT は妥当であったといえる。

2.脳血流動態力ら多た言語半球優位性：BR，DR 両 課題で, Broca野と想定したCh8 と対側部位である Ch22 のタスク区間における $0 \mathrm{xy}-\mathrm{Hb}$ 濃度について平均值を 算出し $\mathrm{t}$ 検定を実施したところ，いずれの課題でも有 意差が生じていた (Fig1， p<．05）。Broca 野は音韻処 理や意味処理などに関与する領域であると考えられて おり，DMT 実施中に左半球の Broca 野が右半球に比心 有意に活性化されることがPETやfMRI 研究で報告され ている (Caplan et al., 2000 ; Thomsen et al., 2004)。 本研究の DR 課題はこれらの研究結果とも一致し,さら に BR 課題でも左半球の $0 \mathrm{xy}-\mathrm{Hb}$ 濃度の増加がみられた ことから，単音節語音の音韻処理でも左半球優位性を NIRSにより捉えうることが示唆された。

3.両耳分離聴に関わる脳領域：DB 課題においては, Ch 5 を中心とする左頭頂領域で $0 \mathrm{xy}-\mathrm{Hb}$ 濃度の上昇が 認められた。両耳に異なる刺激対が呈示される DMT で は，両耳の音に対し均等に注意を向ける必要がある。 頭頂領域は注意機能との関連が報告されおり，多くの 注意資源が両耳分離聴の処理に使用されていることを 反映したものとして注目される。

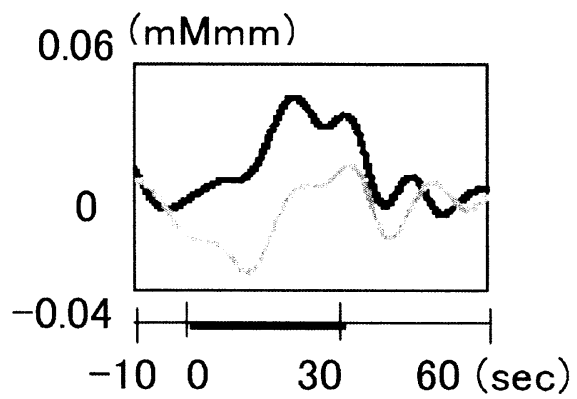

Fig.1. DR(Dichotic-Rest)課題における $\mathrm{Oxy}-\mathrm{Hb}$ 波形 黒線は Ch8，灰線は $\mathrm{Ch} 22$ の $\mathrm{Oxy}-\mathrm{Hb}$ 波形を示す 


\section{大脳半球間転送の単語情報に対する意味処理}

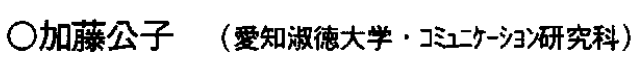

\section{沖田府訔・吉崎一人 - 清水遵}

（愛知淑德大学・コミューケーション学部）

【目 的】 Smith and Jonides（1997)は，空間情報 は右半球で，物品の情報は左半球で貯藏することを示 し，視覚情報はその内容によってどちらかの半球で貯 蔵されることを示唆した。Nowicka, Grabowska and Fersten（1996）は左右大脳半球の機能的非対称性と 半球間転送との関係を検討し，半球間転送は左右大脳 半球の機能的非対称性と関連しており，与えられた情 報の処理に優位でない半球から優位半球へ転送される 方が，その逆よりも転送時間が速いことを示した。上 記 2 つ研究より, 情報の内容によって貯蔵半球が異 なること, さらにその情報が貯蔵されている半球の情 報転送方略によって, 左右半球相互作用による効率的 な情報処理が行われていると考えられる。本研究は言 語刺激を用い，情報の貯蔵と転送の観点から大脳半球 間相互作用メカニズムを明らかにすることを目的とす る。

【方 法】実験参加者 : 21 27 歳の 12 名（男性 2, 女性 10)。刺激材料 : プライムとターゲットは 1〜4 文字で構成される MS UI ゴシック体で描かれた単語 を使用。単語刺激の大きさは，視角にして 1 文字は縦 $1.6^{\circ} \times$ 横 $1.7^{\circ}, 2$ 文字は縦 $3.4^{\circ} \times$ 横 $1.7^{\circ}, 3$ 文字は縦 $5.3^{\circ} \times$ 横 $1.7^{\circ}, 4$ 文字は縦 $7.1^{\circ} \times$ 横 $1.7^{\circ}$ 。プライム と同時に呈示されるパッチは縦 $1.4^{\circ} \times$ 横 $1.4^{\circ}$ の赤色 あるいは青色で塗られた“○”と“田。画面背景は 白色。ブライムとターゲットは画面中央から左右水平 方向に $2.7^{\circ}$ の位置に, パッチは画面中央に呈示。実験 装置：PC と 17 インチ XGA ディスプレイ。刺激呈 示の制御，反応の記録には SuperLab Pro を使用。脳 波は国際 10-20 法による19 部位に装着し, 左右両耳 杂結合を基準として導出。生体アンプにより増幅感度 $20 \mu \mathrm{V} \cdot$ 遮断高周波数 $30 \mathrm{~Hz} \cdot$ 遮断低周波数 $0.05 \mathrm{~Hz}$ ) 後, KCR-000 に記録。手続き: 実験は個別に行われ た。参加者は顔面固定台で頭部を固定され, 画面中央 を凝視するよう求められた。各試行では画面中央に凝 視点が $500 \mathrm{~ms}$ 呈示され, 続いてプライムが $100 \mathrm{~ms}$ 呈示された。プライムと同時にパッチが呈示される条 件では，パッチの色判断（低負荷）またはパッチの色
と形の判断 (高負荷) を要求した。パッチが呈示され ない条件 (負荷なし) ではプライム呈示画面での課題 は要求されなかった。ISI $900 \mathrm{~ms}$ の後, ターゲットが $100 \mathrm{~ms}$ 呈示された。参加者はプライムとターゲット の意味的関連性をできるだけ速く正確に判断し, 反応 ボタンを押すよう要求された。 $1500 \mathrm{~ms}$ の間隔をおい て次試行がスタートした。20試行を 1 ブロックとし, 1 人の参加者に対し 24 ブロック行った。低負荷・高負 荷・負荷なし条件はそれぞれ 8ブロックずつであった。

【結 果 と考 察】プライム呈示後 $600 \mathrm{~ms}$ ら $1000 \mathrm{~ms}$ の緩徐な陰性シフト(SNS)に対しプライム 視野 $\times$ 部位(P3・P4)の分析を行った。P3 ではプライ 厶視野による差は認められなかったが P4では左視野 呈示の方が右視野呈示よりも振幅が大きかった (Figure1)。以上より言語情報に対し左半球は直接投入 された情報も右半球から転送されてきた情報も貯蔵す るが, 右半球は直接入力された情報は貯蔵するが, 左 半球から転送される情報は貯蔵していないことが推察 される。ターゲットに対する N400 (夕ーゲット呈示後 400 $\sim 600 \mathrm{~ms}$ ) の平均振幅よりプライミング効果を算出し, 負荷なし条件におけるプライム視野 $\times$ ターゲット視 野 $\times$ 部位(P3・P4)の分析を行った。P3 部位ではプラ イムが右視野呈示の時, ターゲットが左視野呈示より も右視野呈示においてプライミング効果が大きいこと が確認された。左半球ではプライムが直接投入される 事態において, 後続のターゲットが直接入力されるか 転送によって投入されるかによりプライミング効果に 影響を与えることが示唆される。 P4 部位ではプライ 厶が右視野呈示の場合, ターゲットがどちらの呈示視 野でもプライミング効果が小さいことが認められた。 これは転送されたプライム情報を右半球が貯蔵してい ないために起こったと考えられる。

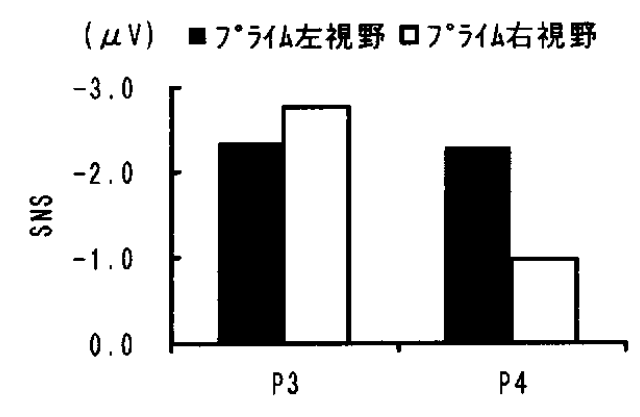

Figure1. 頭頂部の Slow Negative Shift 


\section{検的強度出力課題の多棣練習が CNV に及ぼす効果}

○上野 真保 (早稲田大学大学院スポーツ科学研究科)

正木 厷明 (早榣田大学スポーツ科学学術院)

望月 芳子 (早稻田大学大学院人間科学研究科)

山崎 勝男 (早稲田大学スポーツ科学学術院)

本研究では，運動学習課題の多様練習が随伴性陰性 変動 (CNV) に及ぼす効果を検討した。

\section{[方法］}

被験者 短正を含め視力が正常な常用手を右手とする 大学生 12 名 (男性 3 名, 女性 9 名, 平均年龄 $21.8 \pm 0.6$ 歳)を被験者とした。

課題 左右第 2 指屈曲運動による標的強度值出力課題 を用いた。標的強度值として， $2 \mathrm{~N}, 4 \mathrm{~N}, 6 \mathrm{~N} の 3$ 種類を 設定し， $4 \mathrm{~N}$ を基準課題と定義した．被験者は課題条 件によって, 単一標的条件群 (Single) と複数標的条 件群 (Multiple) の2 群に振り分けられた。

<単一標的条件群>

1 ブロック 60 試行で 10 ブロック実施した. 全ての標 的強度值は $4 \mathrm{~N}$ に設定された。

\section{<複数標的条件群>}

1 ブロック 60 試行で 10 ブロック実施した。試行ごと に異なる 3 種類の標的強度值を出力した。ただし，同 じ標的強度值の試行が 2 回以上連続することはなかっ た. 基潐課題は単一標的条件群, 複数標的条件群とも に $3 n-2$ 試行目に遂行されるように制御した。

保持テスト 実験の翌日に基準課題のみ 20 試行から なる保持テストを実施した。

記録方法 脳波は国際 10\%（拡張 10-20 法）電極配膡 法に基づき，64 部位から導出した。また眼球運動は， 両眼角外 $1 \mathrm{~cm}$ から水平眼球運動, 左眼中心上下 $2 \mathrm{~cm}$ か ら垂直眼球運動を導出した (QuickAmp, BrainProducts)。 いずれも時定数 $4 \mathrm{~s}$, サンプリング周波数 $250 \mathrm{~Hz}$, 高域 遮断周波数は $100 \mathrm{~Hz}$ とした。刺激呈示及び出力強度值 の測定にはLabVIEW を用いた。

分析方法 本研究では基準課題遂行時のみを分析对象 とした。練習期のパフォーマンスは，標的強度值の $4 \mathrm{~N}$ から奏際の出力値を引いたものを計測し，その平均を 恒常誤差 (Constant Error, CE), 標準偏差を変動誤差

(Variable Error, VE) として分析した。CNV は前半 5
ブロック（計 100 試行; Former) と後半 5 ブロック（計 100 試行；Latter）分け, $\mathrm{Fz}, \mathrm{Cz}, \mathrm{Pz}$ を対象に Cue Stimulus 呈示後 $2000 \mathrm{~ms}$ 時点の電位を分析した。保持 テストは練習期と同様に，CEおよびVEを分析した。

[結果]

練習期の基淮課題における出力強度値の $\mathrm{CE}, \mathrm{VE}$ は 単一標的条件群が出力值をオーバーシュートする傾向 だった。一方, 複数条件群では出力値が $4 \mathrm{~N}$ を下回って いた。また，単一標的条件群では右手反応でオーバー シュート傾向にあり, 複数標的条件群ではアンダーシ ニート傾向だった。一方 VEは, 単一標的条件群で有意 に唄差が小さかった $(\mathrm{F}(1,10)=21.23, \mathrm{p}<.001)$ 。 CNV 振幅は, 前半 1 - 5 ブロック (Former) では, 複数 標的条件群の方が単一標的条件群よりも大きかった $\mathrm{t}$

$(10)=2.90, p<.05)$ 。保持テストは, 両群ともに左 手での反応時にオーバーシュート傾向であり，単一標 的条件群の方がパフォーマンスは高かった $(\mathrm{F}(1,10)$ $=8.590, \mathrm{p}<.05)$ 。

\section{[考察]}

本研究では, CNV と運動学習との関連を検討した。 パフォーマンスについては, スキーマ理論で唱えられ ている多様性練習の運動学習促進の効果は見られなか つたが, CNV 振幅について Fz で複数標的条件群の方に 振幅の増大がみられた。これは，運動遂行直前の反応 プログラミング段階におけるパラメータの入力処理に 必要な注意を反映していると考えられる。

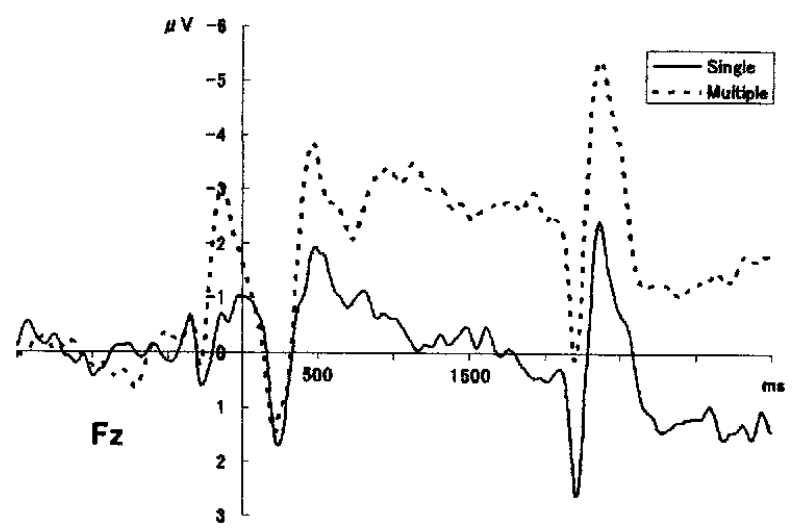

Figure 1. Fz Fromer にお引る CNV 波形 
安静時および運動時における反応時間について

○酒井 康次 (大阪工業大学情報科学部)

井上 裕美子 (大阪工業大学情報科学部)

大須賀 美恵子 (大阪工業大学工学部)

\section{1. 目的}

安静時及び運動時に中心視野および周辺視野に視 覚刺激が出た場合の反応時間にどの程度の違いが見ら れるか，また，反応時間短縮トレーニングを行うこと によってどの程度，反応時間を短縮できるかについて 検討することを本研究の目的とした。

\section{2. 方法}

被験者: 同意書を得た男子大学生 4 名. 実験概要: 反応時間短縮トレーニング 6 回とトレーニング前後に プレ評価及びポスト評価を各 2 回ずつ行った. 視覚刺 邀：6 秒間隔でランダムに 5 つの LED のうち 1 つが光 るという視覚刺激を用いた。 LED の配置は, 球面ディ スプレイ上の中心視野に LED を1つ (ORT), 周辺視野 に 1RT，2RT，3RT，4RT の 4 つの LED を配置した (Figure.1).被験者の目の位置と各LED の距離は $105 \mathrm{~cm}$, $1 \mathrm{RT}$ と $4 \mathrm{RT}$ 間は $181 \mathrm{~cm} ， 1 \mathrm{RT}$ と $3 \mathrm{RT}$ 間は $105 \mathrm{~cm}$ とした。 反応課題 : LED に対応した 5 つのスイッチを設置し, 被験者には LED 点 灯後できるだけ早 く該当スイッチを 利き手拇指で押す 選択反応課題をさ せた・則定項 且:LED 点灯から スイッチが押され

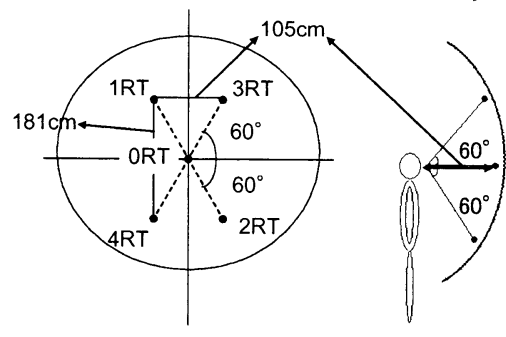

Figure.1 LED の位置
るまでを反応時間として計測し, 心電図, 眼球運動, 拇指球よりスイッチ押しに関する筋電図を測定した。 プレ・ポスト評価: 被験者はエルゴメータに座り安静 状態で 50 回（5 分）の反応課題を行い(安静時プレ), その後 3 分休憩した後,運動時に反応課題を 150 回(15 分）行った(運動時プレ). 運動はエルゴメー夕を用い て被験者の最大心拍数の 45 ～85\%に相当するランプ負 荷で行った。ポスト評価もプレ評価と同様に行った。

\section{3. 結果}

安静時における中心視野と周辺視野の反応時間に ついてみると(Figure.2 左図), 中心視野(ORT)ではプ レ・ポストともに, 周辺視野よりも反応時間が短いこ とが示された $(p<0.05)$. プレとポストを比べてみると
トレーニングによってプレよりポストの方が，45〜 $83 \mathrm{msec}$ 程度反応時間が短縮される傾向があった。

運動時では(Figure.2 右図), 中心視野(ORT)では周 辺視野の 1RT, 2RT より反応時間が短いことが示された ( $\mathrm{p}<0.05) .3 \mathrm{RT} ， 4 \mathrm{RT}$ では短縮傾向があるが有意差には 至らなかった.プレとポストを比べると，1RT，2RT で はポストにおける反応時間の短縮がみられなかったが， ORT，3RT，4RTでは短縮する傾向が示された.

Figure. 3 はある被験者の安静時の中心視野(ORT)に おける全試行のスイッチ反応と積分筋電図を重ねて示 している.反応時間がポストにおいて短縮した場合は， 筋放電潜時が短縮されるという傾向が示された。
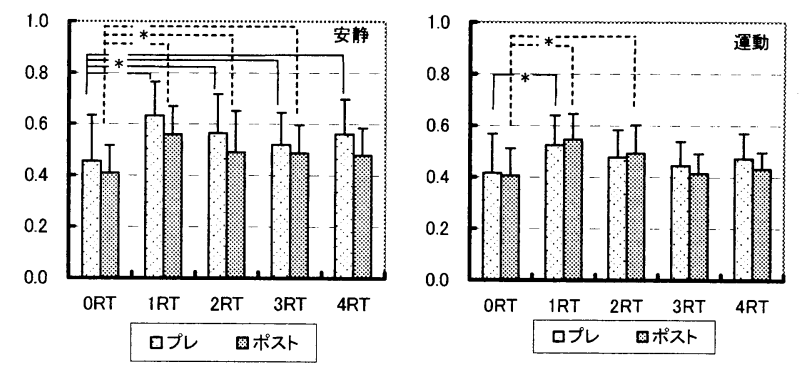

Figure.2 プレ・ポスト評価の反応時間

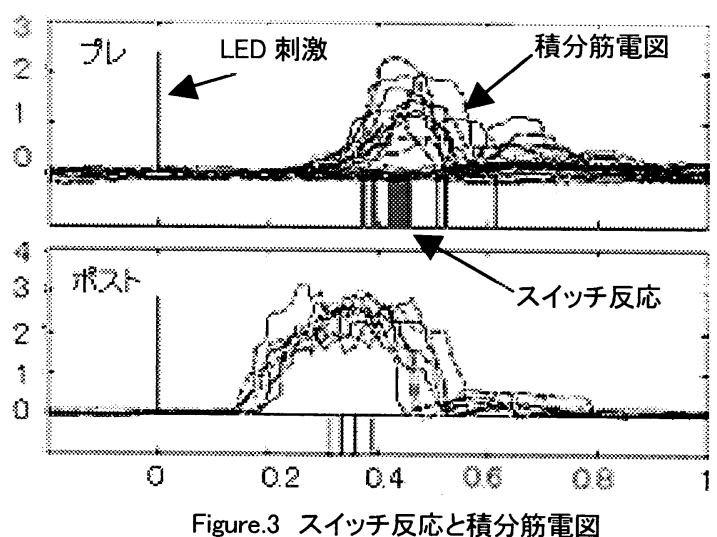

\section{4. 考察}

安静時における反応時間は,中心視野より周辺視野 のほうが遅いことが示された。また安静時ではトレー ニング効果がみられ，反応時間がポストで短縮される 傾向があった，反応時間が短縮された場合，筋放電潜 時が短縮する傾向があり，中枢における判断処理が速 くなり反応時間が短縮するのではないかと推察される. 運動時にトレーニング効果が低かった理由や中心視 野より周辺視野の方が反応時間が遅れる仕組みについ ては，今後トレーニング回数や被験者数を増やし更に 検討したい. 


\section{エラーの重要性を知るタイミングが \\ 行動モニタリングシステムに与える影響}

○村田 明日香・片山 順一

(北海道大学大学院教育学研究科)

行動モニタリングは我々の行動を常にモニタし，エ ラーが生じればそれを検出・修正する脳内システムで ある。このシステムの検討に有効な指標であるエラー 関連陰性電位(ERN) は課題遂行中の誤反応後に生じ, エラー検出とエラーの重要性の評価を反映すると考え られている。本研究は個々の行動の重要性とそれを認 識するタイミングが行動モニタリングシステムに与え る影響について，ERNを用いて検討した。

\section{方 法}

【被験者】12 名（男性 9 名・女性 3 名）

【課題および手続き】一致刺激 (〉》〉》, 《〈〈〈く; 各 10\%) と不一致刺激 $(\langle\langle\rangle\langle\langle\rangle\rangle\langle\rangle$, ; 各 40\%) から成る 4 種 類の反応刺激の中央に提示されたターゲットの向きと 同側の手による反応を求めるフランカー課題を実施し た。凝視点はモニタ中央に常に提示した。Cue1 提示の 1200-1400 ms 後にCue2 を提示し, その 200-400 ms 後 に反応刺激を提示した。刺激提示時間は各 Cue が 200 $\mathrm{ms}$, 反応刺激が $150 \mathrm{~ms}$ であった。被験者にとってのエ ラーの重要性とその認識タイミングを操作するため, 特定の試行における正しく素早い反応に対して金銭報 酬を与えた。さらにその中で被験者が Cue1によって報 酬の有無を知る試行を Long 試行, Cue2 によって知る 試行を Short 試行とし，金銭報酬を伴わない Control 試行と比較した。各試行は等確率でランダム順に提示 した。また被験者毎に RT 基準を設け, それを超えた反 応 (遅延反応) は正誤に関わらず報酬は与えなかった。 被験者にはできるだけ多くの報酬獲得を目指して課題 を遂行するように教示した。

【記録·処理】EEG はバンドパス 0.05-30 Hz で頭皮上 28 部位から鼻尖基準で記録し, 両耳梁基準で再計算した。 各試行の反応正誤毎に反応前 $100 \mathrm{~ms}$ から反応後 $600 \mathrm{~ms}$ 間で加算平均した。なお遅延試行は分析から除外した。 ERN 振幅は前の陽性ピークからの変化量とし, 正反応 ERP は反応後 50-200 ms 間の平均振幅で評価した。

\section{結果及ひ考察}

【行動指標】Controlよりも Long, Short 試行で正反応率 が高く, 全試行タイプにおいてエラーの尚早反応が見
られた。また干渉効果が生じ，一致刺激よりも不一致 刺激の方が正反応率が低く, RT が延長した。

【ERP】 $\mathrm{Cz}$ における総加算平均波形と $\mathrm{Fz}, \mathrm{Cz}, \mathrm{Pz}$ から 得た ERN 振幅をFig. 1 に示した。全てのエラ一試行で 明瞭な ERN が観察され，ERN は Short, Control 試行 よりも Long 試行で有意に増大した。正反応 ERP では Control よりも Long 試行, また $\mathrm{Pz} よ り も \mathrm{Cz}$ で有意な 振幅の増大が見られた。

行動指標の結果は, 被験者が報酬の有無によって反 応方略を変化させたことを示している。ERP の結果は, 反応刺激提示の直前に報酬の有無を認識するときのエ ラーと比べ, 予め報酬が与えられることを認識してい たときのエラーのみが重要なエラーとして評価される こと，また報酬が与えられないときと予め報酬が与え られることを認識しているときでは，正反応処理が異 なることを示している。

報酬が与えられないときのエラー処理と比較して， 被験者が予め報酬関与を認識している場合は行動遂行 直後のエラ一検出と同時に, その重要性も評価される。 一方, 行動遂行の直前に報酬関与を認識する場合は行 動遂行直後にはエラーの重要性が評価されず, エラー 検出のみが行われる。このことから, 行動モニタリン グシステムは行動の重要性をいつ認識するかに関わら ず，より重要なエラーを犯さぬように行動を制御する が，エラーの重要性を知るタイミングが行動開始時点 に近いとき, 行動遂行直後の正誤判断と同時並列的に は評価されないことが示唆された。さらに, 正反応処 理は行動の重要性によって変化しないと考えられてい たのに反し, 本研究では行動の重要性が正反応処理に 影響を与える可能性が示唆された。
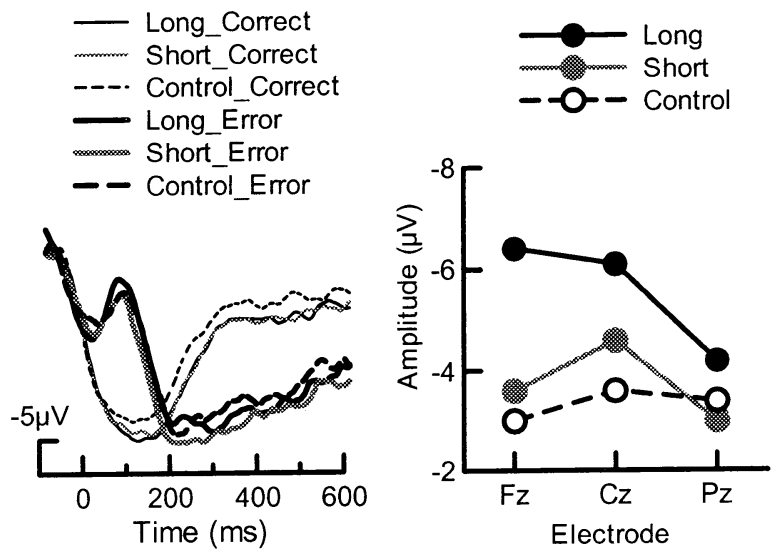

Fig. 1. 総加算平均波形 $(C z)$ および ERN 振幅(右) 
誤反応認知が次試行のパフォーマンスに与える影䈏 : 反応時およびフィードバック時の ERPによる検討

$\mathrm{O}$ 板垣 俊・片山順一

(北海道大学大学院教育学研究科)

選択反応課題での誤反応時に反応 ERN が惹起され, 誤反応情報や悪い事象がフィードバック（FB）され た時に FB-ERN あるいは FRN が惹起される。いずれ も誤反応認知に感度を持ち, 課題遂行時のモニタリン グ機能と関わる ERPである。本研究では，FB 呈示を 伴う制限時間付きのフランカー課題を行い, 誤反応認 知が次の試行のパフォーマンスに与える効果について ERPを用いて検討した。

\section{方 法}

【被験者】視力または矯正視力の正常な大学生 12 名。 【課題】 FB 刺激を伴う制限時間付きのフランカー課 題を行った。中心に呈示された矢印の向きの手で, 制 限時間内に早く正確に反応することを要求した。

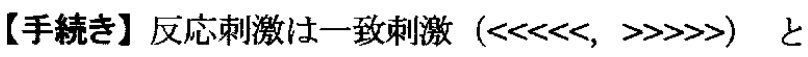
不一致刺激 (〉>>, 《く<) を等確率で呈示し, 中心を標的刺激とした。また FB 刺激は，被験者ごと に設定された制限時閒内の正反応には “correct！”, 制限時間内の誤反応に “incorrect”，制限時間を超過 して反応した場合は左右の正誤に関わらず，“too late!!”を呈示した。反応刺激を $150 \mathrm{~ms}$ 間呈示し，ボ タン押し反応の $1200 \mathrm{~ms}$ 後に FB 刺激を $500 \mathrm{~ms}$ 間呈 示した。1000-1750 ms 間のブランクの後, 次試行を 開始した。制限時間は被験者ごとに練習試行での平均 反応時間とした。左右の選択を誤った場合も制限時間 超過した場合もエラーとなることを教示した。1 ブロ ックは 48 試行から成り, 18 ブロック実施した。

【記録および処理】制限時間内の正反応 (CR) と誤反 応 (IC)，制限時間超過時の正しい反応 (TLCR) と誤 反応 (TLC) の 4 つの反応カテゴリに分けた。EEG はバンドパス 0.05-30 Hz, サンプリング周波数 $250 \mathrm{~Hz}$ で，両耳氺を基淮として，頭皮上の 30 部位から記録 した。加算平均区間は, 反応前 $100 \mathrm{~ms}$ 加反応後 500 $\mathrm{ms}$ と FB刺激呈示前 $200 \mathrm{~ms}$ 加刺激呈示後 $700 \mathrm{~ms}$ までとした. 反応時の ERP は反応後 0-100 $\mathrm{ms}$ 間, $\mathrm{FB}$ 時の ERP は刺激呈示後 250-350 $\mathrm{ms}$ 間の平均振幅 として評価した。CR，IC，TLCR のカテゴリについ
て, 次試行のパフォーマンス (CR, IC, TLCR) ごと に再分類し，反応時および FB 時の ERP を比較した。

\section{結果および考察}

【行動指標】制限時間内の唄反応に尚早反応が見られ た。一致刺激よりも不一致刺激で RT が延長し, 誤反 応が増加した。この結果は従来のフランカー課題の結 果と一致している。

【ERP】次試行のパフォーマンスごとに分類した 3 つ の反応カテゴリのうち，IC と TLCR の ERP 波形を Figure 1 に示す。それぞれ平均振幅について, 次試行 (CR, IC, TLCR) と電極部位 $(\mathrm{Fz}, \mathrm{FCz}, \mathrm{Cz}, \mathrm{Pz})$ の 2 要因分散分析を行ったところ, いずれの波形にも有意 な効果は見られなかった。この課題では, 被験者が反 応時に選択の正誤を認識でき，制限時間内に反応でき たかについては，FB 刺激を手がかりにして認識でき る。誤反応時に生じる ERN が即座に次試行の反応の 調整に寄与するのであれば，次試行が正反応である場 合の ERP 振幅が大きくなると予想できるが，反応時 および FB 時の ERP 振幅に差がなかった。また, 制 限時間超過時においても，次試行の反応時間が短縮さ れた場合と，それ以外の場合でも，反応時および FB 時の ERP 振幅に明暸な差を検出できなかった。これ らのことは ERN を惹起させる誤反応認知が，直接的 には次試行に影響しないかもしれないことを示してお り, 呮反応認知と直後の反応の調整が分離している可 能性が示唆された。

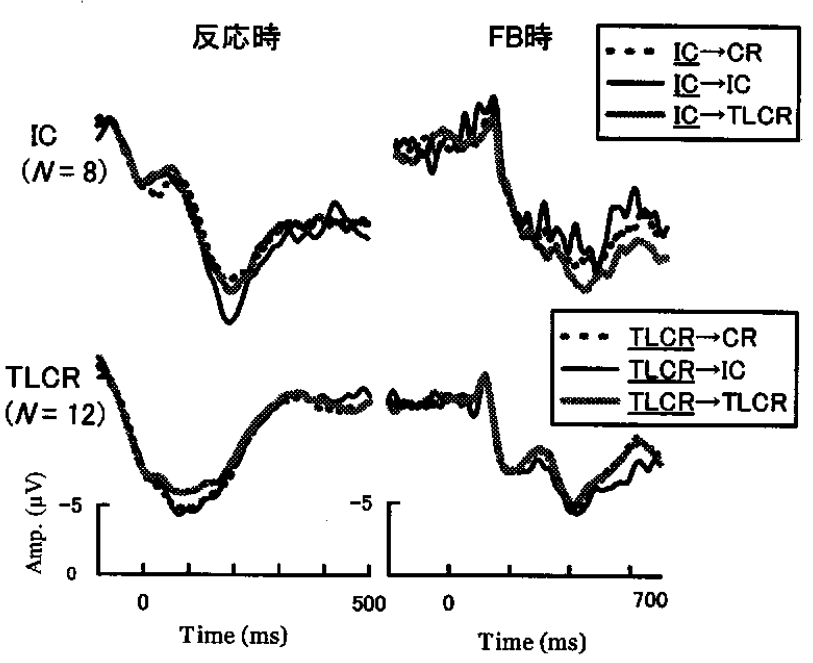

Figure 1. 反応時と FB 時における FCz での IC と TLCR の総加算平均波形 
視覚と固有受容感賞を矛盾させた状態での運動適応 に対する前頭前野の関与

- 到達運動中の近赤外分光法による検討 -

\section{○後藤 広太郎 (北海道大学大学院教育学研究科) \\ 星詳子 (東京都精神医学釉合研究所) \\ 高橋 誠 (北海道大学工学部) \\ 室橋 春光 (北海道大学大学院教育学研究科)}

本研究では, 空間的に視覚と固有受容感覚を矛盾さ せた（左右反転）状態における運動適応の推移と， それに対する背外側前頭前野（主にブロードマン $9,10,46$ 野）の関与について, 近赤外分光法（Nearinfrared spectroscopy：NIRS）を用いて検討した。

\section{【方法】}

右利きの大学生・院生計 8 名 (男性 4 名, 女性 4 名: 18 歳〜30 歳, 平均年齢 23 。4 歳) 被検者とした。 被検者には, 頭部に装着されたプロジェクターを通 して平面上に投映されるターゲット（スタート地点 の前方 45 度の方位, 距離 $15 \mathrm{~cm}$ に位置を設定) に向 けて，できる限り正確に素早く手を移動するように 指示した。課題遂行中, 被検者は自身の指先を見る ことはできず，その代わりに指先位置を示すカーソ ルから視覚的フィードバックを得ていた。左右反転 課題を 6 試行ずつ 6 ブロック（36 試行）行ったが, 左右反転とは, カーソルの進行方向を左右に反転さ せ, 視覚と指先位置感覚の関係を矛盾させた状態で ある。赤外線酸素モニ夕装置（浜松ホトニクス製 NIR0-300)のプローブを被検者の前額部左右 2 箇所 に装着し，oxy-Hb deoxy-Hb total-Hb を計測した (照射一受光部間距離, $3 \mathrm{~cm}$; 波長， $775 ， 810,850$, $910 \mathrm{~nm})$ 。なお, 学習の度合いを計測する行動指標と して「到達運動軌跡の誤差」と「運動反応時間」を 設定した。

\section{【結果】}

行動指標: 一要因分散分析の結果, 運動軌跡の誤差・ 運動反応時間において，ブロック間平均值にそれぞ れ有意な差がみられた（p<.05, p<.01）。全体の傾向 としては第 1 ブロックで最も軌跡の誤差が大きく, 第 6 ブロックにおいて最も軌跡の誤差が小さかった。 反応時間においても同様の傾向が確認された(図 1)。 $\mathrm{Hb}$ 相対濃度変化： 8 人の被検者全員に第 1 ブロック
において最も顕著に oxy一Hb の増加がみられた。こ の現象は左右 2 箇所の部位両方において確認された

(図 2)。deoxy-Hb に関しては，被検者によって変 化の度合いが小さい場合があり, ブロックごとの変 化に一定の傾向は認められなかった。第 1 ブロック における $\mathrm{oxy}-\mathrm{Hb}$ の変化パターンは先行研究(後藤ら, 2004）と一致していた。

【考察】

結果から, 運動適応の推移と $\mathrm{oxy}-\mathrm{Hb}$ 相対濃度変化の 対応が明らかにされた。このことは，背外側前頭前 野が運動適応に関与することを示唆している。 Quintana ら (1999) は, 背外側前頭前野が実行系機能 を担っていることを報告しており，視覚と固有受容 感覚の空間的矛盾（左右反転）状態時における到達 運動の制御をおこなっているものと推測された。ま た Fuster (2000) は, 前頭前野が知覚一行為循環の頂 点に立ち，不測の事態等に対する方略形成に関わる としており，左右反転という日常生活では体験しな い不測の事態に対応するため，第 1 ブロック時に前 頭前野の左右 2 箇所がより賦活したものと考えられ た。今後の課題として多チャンネル装置を用いて計 測を行い, 前頭前野における複数領域の関与の検討 が挙げられる。

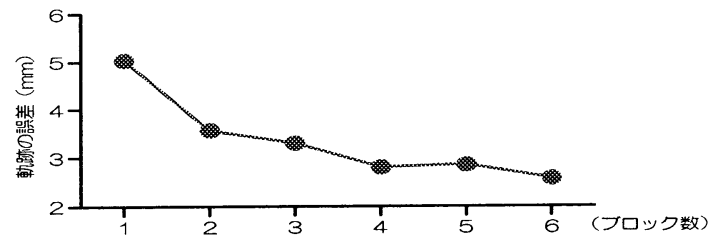

図 1: 到達運動課題遂行時の運動反応時間の変化
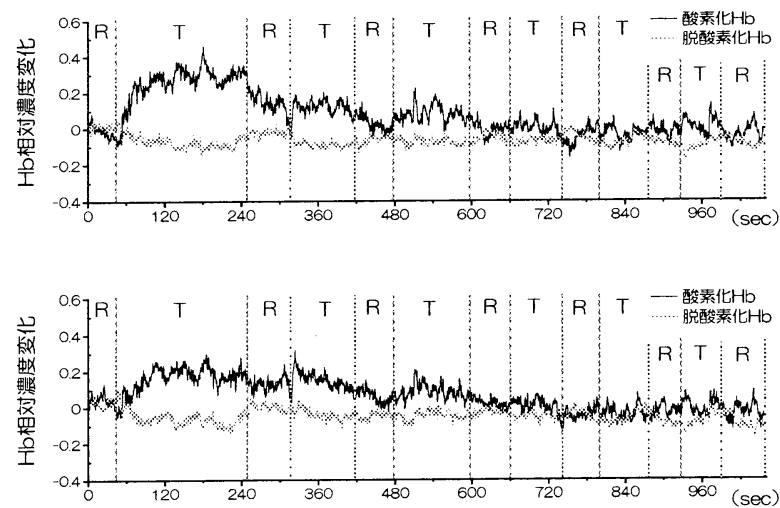

図 2: 到達運動課題遂行時の $\mathrm{Hb}$ 相対濃度変化の 1 例 (18 歳女性 : 上が右部位で下が左部位。 R一安静, $T$ 一課題) 


\section{手指の運功方向の決定過程に関する 生理心理学的検鄟（2） \\ 一一過性心拍反纯を中心に -}

\section{○水田 敏郎（仁学人䦥学部）}

宮地弘一郎（金沢大学 21 世紀 COE (革新朕科学) 技術員) 吉田 和典 (仁受大学人間学部)

藤澤 清 (仁大学人間学部)

\section{1. 目的}

予告刺激 $\left(\mathrm{S}_{1}\right)$ と命令刺激 $\left(\mathrm{S}_{2}\right)$ からなる二種一対の 刺激提示下 $\left(\mathrm{S}_{1}-\mathrm{S}_{2}\right.$ パラダイム)において，命令刺激 到来に対する構えが形成される際，二刺激閒の一過性 心拍反応は第 1 减速（the first decelerative component；D1）一加速 (accelerative component ; A) 一第 2 减速（the second decelerative component; D2) の三相からなるとされる。本研究では手指の運動方向 の決定過程について検討するために， $\mathrm{S}_{2}$ 提示後に水平 面四方位に配置したスイッチ（SW）を常用手第二指で 押すといら課題を設けた。さらに，あらかじめ決めら れた位置の SW を押す場合と被験者の自由意思により 決められた SW を押す場合の異なる条件下で心拍を記 録し，刺激間間隔（ISI）において生じる一過性反応に ついて比較検討することを目的とした。

2. 方法

(1)被験者 : 大学生 12 名（男女各6名）を対象とした。 平均年齢は 21.3 歳（範囲 20-22 歳) で, 常用手は全 員右手であった。

(2)課題：予告刺激として $1000 \mathrm{~Hz}$ 純音 (65dBHL, dur. $100 \mathrm{~ms}: \mathrm{S}_{1}$ ) を提示し， 4 秒後に命令刺激として $2000 \mathrm{~Hz}$ 純音 $\left(65 \mathrm{dBHL}\right.$, dur. $100 \mathrm{~ms}: \mathrm{S}_{2}$ ) を提示した。被 験者は $\mathrm{S}_{2}$ 後, 手元を見ずに水平面上四方向に配置され た 4 つの SW のうち 1つを常用手第二指で押した。 4 つ のSW は, 被験者の指先を中心とした $5 \mathrm{~cm}$ 四方内に水平 面上の前後左右四方向に配置された。

(3)条件： $\mathrm{S}_{2}$ 後にあらかじめ指定した位置の SW を押す 条件 $\mathrm{A}$, 自分が決定した位置の $\mathrm{SW}$ を押す条件 $\mathrm{B}$, 同じ く自分が決定した位置の SW を左右交互に押す条件C を設けた。いずれも被験者は座位姿勢で，SWを押した 後は 4 つのSW の中央に指を戻すよう指示した。

(4)記録 : SW を押したときのタイミングマークと心電図 を記録した。心電図は，修正第 II誘導法にもとづき胸 部より導出し TC 1.5 秒, $\mathrm{Hi}$-cut $30 \mathrm{~Hz}$ で増愊後, 磁気
記録した。

(5)手続き : $\mathrm{S}_{1}, \mathrm{~S}_{2}$ のセットを 1 trial とし, 各条件 30 trial を連続して行った。条件間に約 3 分の休憩をは さみ，条件の提示順序はカウンターバランスした。 (6)分析方法 : SW のタイミングマークから, 各条件で選 択された SW 位置の平均割合および平均反応時間を求 めた。心電図は $R$ 波を検出後, $R-R$ 間隔を求め $S_{1}$ 前 2 秒から $\mathrm{S}_{2}$ 後 5 秒の計 7 秒間について second by second 分析により 0.5 秒毎の心拍值を求め条件毎に加算平均 した。

\section{3. 結果と考察}

(1)SW の選択と反応時間 : 各 SW の選択される割合につ いてみると条件Bではいずれの位置の SW もほぼ等し い割合で選択されていたのに対し，条件Cでは常用手 において常用手とは対側の SW を選択する傾向が認め られた。このことは，運動する方位の選択などを企図 する意識が常用手において薄れやすいことの表れでは ないかと推測される。また, 反応時間は全試行の平均 からみると条件 $\mathrm{A}$, 条件 $\mathrm{B}$, 条件 Cの順で延長したが， 前半と後半では後半に短縮した。この結果から, 運動方位決定の過程が $\mathrm{S}_{2}$ 提示直後まで影響するが, 後 半慣れが生じたことが示唆される。

(2)一過性心拍反応 : ISI における心拍値の時間経過 (図 $1:$ 全試行の平均) から条件Aが最も早く $\mathrm{S}_{1}$ 後に減速 し，他の 2 条件に比べると刺激前水準に対する有意差 が生じる時間帯も早いことがわかった。このことから， 条件Aでは「D1（定位的減速）-D2（予期的诚速）」の 出現が優勢なのに対し，他の 2 条件は $\mathrm{S}_{1}$ 後に加速方向 に推移し，この反応が運動方位決定の過程に関与して いる可能性が示唆された。

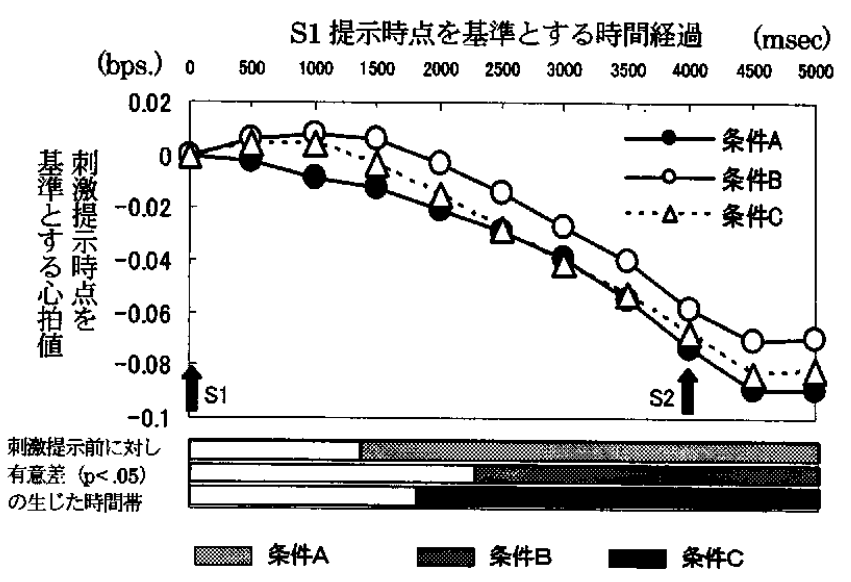

図 1. 条件別の心拍值の時間経過と検定結果（全言衍）. 


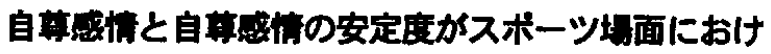 るパフォーマンスに及ぼす影}

○堀川雅美 (関西学院大学大学院文学研究科)

八木昭宏 (関西学院大学文学部)

\section{【目的】}

不安定で高い自尊感情を持つ人は安定的で高い自尊 感情を持つ人より, 失敗に対して自信丧失感情を持つ。 また, 安定的で高い自尊感情を持つ人は失敗に対して 回復力を持っている。

課題を行う時, 個人内での要求と対処の関係から課 題を挑戦か脅威のいずれかに評価する。評価が挑戦で も劦威でも，心臓活動は増加するが，妿威では挑戦ほ ど增加しない。そして, パフォーマンスは挑戦のほう が妿威より良い結果になる。

本実験では自尊感情がスポーツ競技場面におけるパ フォーマンス, 不安, 心臓活動や課題に対する認知的 評価にどのような影響を与えるかについて検討する。

\section{【方法】}

被䠝者 : K 大学体育会サッカー部員 23 名(平均年齢 20.3 歳, 平均サッカー歴 13.1 年)

锞題：直径 $1 \mathrm{~m}$ の円の中で, 様から下を使用し，左右 交互にリフティングを行った。

武行：リフティングを継続できなくなるまでを 1 試行 とし, 約 10 日間の間隔をあけて 2 試行行った。

行動指桖：リフティングの回数と時間を測定した。

心理指標 : 状態一特性不安尺度(State-Trait Anxiety Inventory ; STAI), 自尊感情尺度, これから行う課題 に対する認知的評価，今行った課題に対する認知的評 価を測定した。

生理指標：ハートレイトモニターPOLAR ELECTRO 社)により， 5 秒間隔で心拍数を測定した。

手綍き：ハートレイトモニターを装着し，ベースライ ンとなる心拍数と状態不安得点, 自尊感情尺度を測定 した。その後教示を行い, 心拍数と状態不安得点, こ れから行う課題に対する認知的評価を測定して, 課題 を行った。課題終了後, 今行った課題に対する認知的 評価を測定した。

結果の処理 : 1 回目と 2 回目の自尊感情得点の平均値 および変化量を求め, 各平均点を基準として, 被験者 を自尊感情が安定的で高い群, 不安定で高い群, 安定
的で低い群，不安定で低い群の 4 群に分けた。

1 回目と 2 回目のリフティング回数, 状態不安得点, 課題に対する認知的評価得点, 心拍数の変化量につい て検剖した。

\section{【結果】}

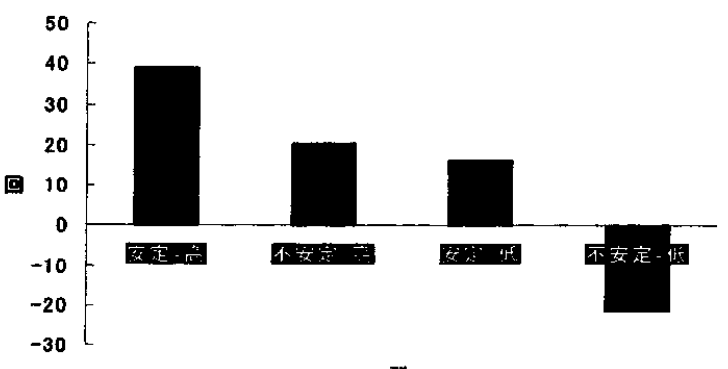

Figure 1. 各群のリフティング回数の表化量。

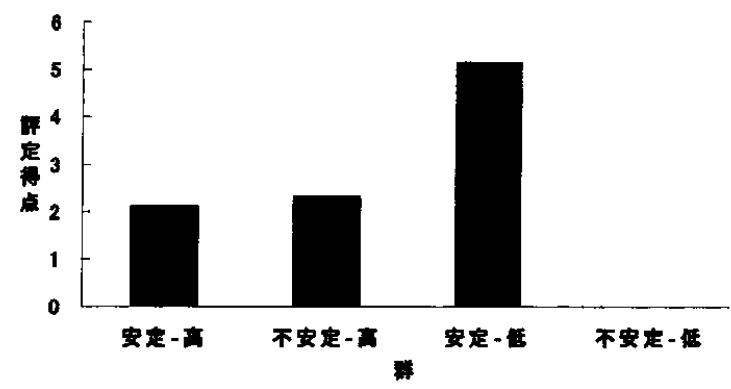

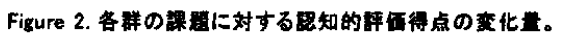

1回目と2回目のリフティング回数の変化量につい て, 安定的で高い群では有意な差が見られた $(t=2.11$, $d f=7, p<10)$ 。つまり，1回目より2回目のほうがリ フティング回数は増えた。

1回目と2回目の課題についての認知的評価得点に ついて, 安定的で高い群は有意な傾向が見られた $(t=4.34, d f=7, p<.01)$ 。つまり，1回目より 2 回目の ほうが課題を妿威と捉えた。

1回目と2回目の間で不安と心拍数については有意 な差は見られなかった。

\section{【考察】}

安定的で高い自尊心を持つ人は, 1回目より2回目の パフォーマンスが上がったことから，失敗に対して回 復力を持っていると言える。これは課題を弈威亡捉え た場合，パフォーマンスが下がるというBlascovichら (2004)の結果とは一致しなかった。

(HORIKAWA Masami, YAGI Akihiro) 
反応タイミングに及ぼす試行間間隔の影響

-CNV と LRP による検討-

\section{○望月 芳子 (早稲田大学大学院人間科学研究科)

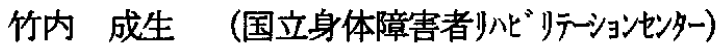 \\ 正木 宏明（早稲田大学スポーツ科学学術院） \\ 高澤 則美 (江戸川大学社会学部) \\ 山崎 勝男（早稲田大学スポーツ科学学術院）}

\section{【目的】}

随伴陰性変動(CNV)パラダイムでは，S2に対して速 く正確な反応が要求され, foreperiod(FP)では時間的 情報処理と反応淮備が行われる 本研究では, 試行間間 隔(ITI)を操作し(3 s/10 s)，タイミングがとり易い条 件と, とり難い条件における時間情報処理と反応準備 との関係を調べた. 反応時間 (RT)，CNV，偏側性準備電 位 (LRP)を指標とした．長 ITI 条件では，RT の相対的 遅延, 前期 CNV の振幅増大，FP-LRP の振幅増大遅延が 予測された。

また, 反応タイミングの相違が運動プログラミング に及ぼす影響を調べた。時間的情報処理は運動実行段 階に影響する(Sanders, 1980).

\section{【方 法】}

被験者：成人 12 名（男子 8 名, 女子 4 名）を被験者 とした. 年齢は $24.7 \pm 2.8$ 歳であった.

条件，刺激，手続き： CNV パラダイムに基づく単純 反応課題 2 条件 [短 ITI 条件 (ISI $3 \mathrm{~s} /$ ITI $3 \mathrm{~s}$ ), 長 ITI 条件(ISI 3 s/ITI $10 \mathrm{~s}$ )] を実施した. 2 条件とも 警告刺激 $(+)(\mathrm{S} 1$; ピンク/ブルー: $3 \mathrm{~s})$ の呈示後に, 命 令刺激として円図形(S2；ピンク/ブルー)を画面に呈示 した. 被験者は，円に対して速やかに，右手第 3 指ま たは左手第 3 指の伸展運動によるキー上げを行った. 円図形(ピンク/ブルー) と反応指(右手第 3 指/左手第 3 指)との対応， 2 条件呈示順序は被験者間でカウンタバ ランスした. 条件 1 (40試行 $\times 5$ ブロック), 条件 2(20 試行 $\times 10$ ブロック)を行った.

記録および分析方法：EEG は 23 部位から左耳垂を基 準に時定数 $10 \mathrm{~s}$ ，高域遮断周波数 $100 \mathrm{H} \mathrm{z}$ で, EOG は 時定数 $10 \mathrm{~s}$, 高域遮断周波数 $100 \mathrm{~Hz}$ で導出した. 反 応指の EMG は時定数 $0.03 \mathrm{~s}$, 高域遮断周波数 $1500 \mathrm{~Hz}$ で導出した. EEG は S1 呈示をトリガとして加算平均し た. RT が $800 \mathrm{~ms}$ 以上の試行は分析対象から除外した. LRPは, C3, C4 から算出した。

$\mathrm{CNV}$ は，23 部位で $\mathrm{S} 1-\mathrm{S} 2$ 間を $200 \mathrm{~ms}$ 毎に分け，各区
間の平均振幅值について, 部位 $(23) \times$ 条件(短 ITI 条件 /長 ITI 条件)の 2 要因分散分析を行った. FP-LRP は, $\mathrm{CNV}$ の統計対象区間に順じ, 平均振幅值について片側 $\mathrm{t}$ 検定を行った. S1-locked-LRP(SLRP) と responselocked-LRP(RLRP) は, regression 法 (Mordkoff, \& Gianaros, 2000) で onset 潜時を決定し, Jackknife 法 (Miller et al., 1998)を適用した.

\section{【結果および考察】}

RT は短 ITI 条件 $(235 \mathrm{~ms})$ のほうが長 ITI 条件 $(250 \mathrm{~ms})$ より有意に早期化した $(\mathrm{t}(11)=2.27, \mathrm{p}<.05)$. CNV 振幅 は部位 $\times$ 条件で交互作用があった. 多重比較の結果, $\mathrm{FCz}$ (800-1000 ms) で短 ITI <長 ITI の傾向があり，Fz, $\mathrm{Cz}, \mathrm{CPz}, \mathrm{Pz}$ (2400-2600 ms), Cz, CPz, Pz (2600-2800 ms), $\mathrm{Cz}$ (2800-3000 ms) で長 ITI<短 ITI であった $(\mathrm{ps}<.05)$. また, FP-LRP 振幅は 400-600 ms, 1400-1600 ms, 22002400 ms， 2800-3000 ms で, 長 ITI<短 ITI であった (psく.05). SLRPの onset は長 ITI より短 ITI の方が早 かった $(\mathrm{t}(11)=2.19, \mathrm{p}<.05$, 片側)，RLRP には差がなか った $(\mathrm{t}(11)=0.19, \mathrm{n} . \mathrm{s}$, , 片側 $)$.

長 ITI 条件の FP-LRP 振幅增大が遅延したことから, FP 中における反応準備遅延が RT 遅延に影響を及ぼし たことが示唆された. また, 長 ITI 条件では CNV 前期 成分の増大が観察された.この増大は $\mathrm{S} 1-\mathrm{S} 2$ 時間間隔 検索に起因し，反応準備の遅延に影響したことが考え られた．また，図 1 はSLRP と RLRP の波形である. ITI 操作による反応タイミングの相違は，運動プログラム における運動実行段階には影響を及ぼさず，実行段階 前に影響を及ぼすことが示唆された。
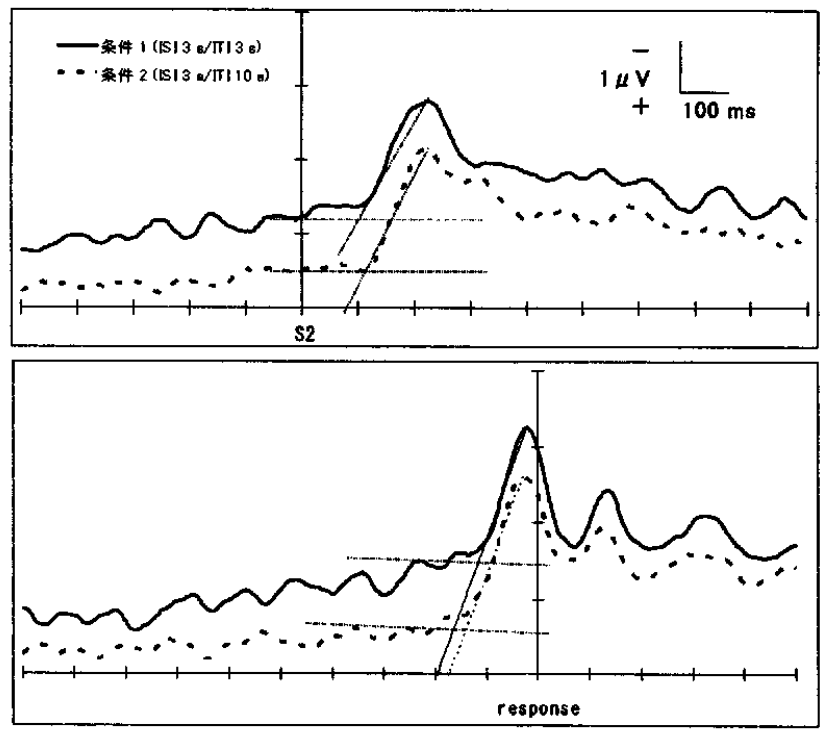

図 1 S1-locked LRP, response-locked LRP 波形 
Event-related fMRI を用いた刺激先行陰性電位 (SPN) の発生源に関する研究

○小谷泰則 (東京工業大学大学院・社会理工学研究科), 大上淑美 (東京工業大学大学院・社会理工学研究科), 塚元鉄二 (GE 横河メディカルシステム (株) ・研究開発室), 中山実 (東京工業大学大学院・社会理工学研究科), 井上優介 (東京大学・医科学研究所)

\section{【目 的】}

統合失調症などの患者では視床における情報の Gating 機能に障害があるといわれている（Gogos et al., 2005)。刺激先行陰性電位（Stimulus-Preceding Negativity; SPN)は,フィードバック刺激といった 情報を持った刺激の前に出現する陰性緩電位であり， 知覚予期 (perceptual anticipation) や情動予期 (emotional anticipation) と関連していると考えられ ている (Ohgami et al., 2004)。この SPN は刺激の出 現を予期した場合に発生することから，視床におい て行われている Gating と関連した脳電位であると考 えられている(Brunia, 2001)。

SPN の発生源に関する研究としては, (1) 脳 波 dipole modeling (Böcker et al., 1994), (2) PET (Brunia et al., 2000)を用いた研究がある。また我々は Block 解析を用いた fMRI の研究を行い, SPN の発生 源として Insula などが発生源ではないかと推定した (Tsukamoto et al., 2006)。しかし,この研究では Block 解析を用いたために観察された眇活動が刺激 呈示直前の予期を反映した活動であるか確認するこ とはできなかった。そこで, 本研究では時間分解能 の優れた Event-related fMRI 用いて SPN の発生源 についてより詳しい検討を加えることを目的とした。

\section{【方 法】}

被験者：成人男女 24 名

課題 : 時間評価課題

被験者は足下のスクリーンに投影された指示刺激 $(-, 1,+)$ が消えた時点から 4 秒，6秒，もしく は 8 秒が経過したと思ったならば右手人差し指でボ タンを押すよう求められた。指示刺激が「 -」の

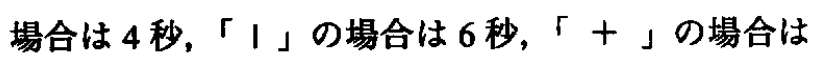

8 秒経過したと思ったならば, 被験者は右手人差し 指でボタンを押すよう指示された。ボタン押しから 3 秒後に時間評価が指定された秒数より早かったか (-), 指定された秒数であったか（１），指定され た秒数よりも遅かったか (+)という FB 刺激が与え られた。被験者は可能な限り正解を出すように要求 された。

実験条件

（1） Fixed 条件（高予期条件）： ボタン押しから FBまでの間隔が 3 秒に固定さ れた条件

（2） Random 条件（低予期条件）:

ボタン押しから FB までの間隔がランダムに 設定されている条件

\section{（3） No FB 条件（統制条件）：}

FB 刺激が呈示されない条件

$<$ MRI 湘定 $>$

MRI 装置: 1.5-T GE scanner (echo planar imaging, 30 slices, $5 \mathrm{~mm}$ thickness, $\mathrm{TR}=3 \mathrm{~s}, \mathrm{TE}=40 \mathrm{~ms}$,)

分析：SPM2 を使用

1) Preprocessing (SPM2)

Realignment, Slice timing correction, Normalization

\section{2) Regressor}

a) ボタン押し後 $1000 \mathrm{~ms}-3000 \mathrm{~ms}$ b) ボタン 押しの時点 c) 指示刺激呈示の時点

\section{【結果と考察】}

刺激予期が容易な（Fix 条件 - No FB 条件）の比 較では, 視床, 下頭頂小葉(BA40)の活動が観察され た。視床が Gating（Brunia, 2000）を行い, 視覚刺激 の呈示を予期したために下頭頂小葉と視床の活動が 観察されたのではないかと考えられる。

SPN の発生源を最も反映していると考えられる (Fix 条件 - Random 条件) の比較では, わずかな活 動しか認められなかったが, 右半球 (下頭頂小葉, operculum, 中前頭回)において活動がみられた。こ れらの活動領域は, SPNの右半球優位性と一致する。 視覚刺激を用いた場合, これらの領域がSPNの発生 源になっているのではないかと考えられる。 
刺激先行陰性電位（SPN）に対する 刺激様式の影響 ーコヒーレンス解析を用いて-

○大上淑美 (東京工業大学大学院・社会理工学研究科) 小谷泰則 (東京工業大学大学院・社会理工学研究科)

塚元鉄二 (GE 横河メディカルシステム (株) ・研究開発室) 井上優介 (東京大学・医科学研究所)

【目 的】

中山実 (東京工業大学大学院・社会理工学研究科)

課題に関するフィードバック（FB）刺激を反応の 2〜3 秒後に被験者に提示すると FB が出るまでの間 に刺激先行陰性電位（SPN）と呼ばれる陰性の緩電 位が出現する。SPN は，FB 刺激などの前に出現す るということから予期に関連していると言われてい る（Brunia \& Damen, 1988)。SPN は異なる刺激様式 により,皮質に局在した活動の高まりが観察できる。 例えば,視覚刺激呈示の場合には後頭部の活動が高 まり,聴賞刺激呈示の場合には前頭部の活動が高ま る (Brunia \& Van Boxtel (2004); Ohgami et al. (2004))。 また,SPN は賞金を用いた場合に振幅がより高まる という結果から(Kotani et al. 2001, 2003; Ohgami et al., 2004)，情動と動機づけに樑く関与した脳波であると も示唆されている。デー夕分析は, 通常,全被験者を まとめて,FB が呈示される $200 \mathrm{~ms}$ 間の平均電位を分 散分析を用いて異なる条件間を比較する方法での検 討が行われる。そのため,各試行ごとの周波数パワー 值とSPN との関連性についての研究は少ない (Bastiaansen et al., 2002)。本研究では,異なる FB 刺 激を呈示された脳波データを BESA を用いて, コヒ ーレンス分析を行い,刺激様式の違いがあるのかど うかを検討する。

\section{【方 法】}

被験者: 成人男女 20 名（男性 17 名、女性 3 名） 脳波記録：時定数 10 秒で,脳波は頭皮上 25 ヶ所 (Fp1, Fp2, F3, F4, F7, F8, FC3, FC4, C3, C4, CP3, CP4, P3, P4, T3, T4, T5, T6, O1, O2, Fz, FCz, Cz, CPz, $\mathrm{Pz}$ ) 加,眼球電位（左右）と筋電位（右手第 1 骨間 筋）も測定した。

課題 : 時間評価課題 (SPN 測定); 指定された時 間が経過したと思ったならば, 右手人差し指でボタ ンを押す (Kotani \& Aihara, 1999)。ボタン押し（BP） の 3 秒後に時間評価のパフォーマンスに関する FB
情報 (BPが指定された時間内であったか否か) を視 覚 FB 刺激（LED の点灯パターン）と聴覚 FB 刺激 $(500,1000,2000 \mathrm{~Hz})$ を用いて呈示する。

分析 : 条件毎に BP 前 $2.5 \sim 1.75$ 秒間の平均電位を 基線とし, BP 前 2.5 秒から BP 後 4.5 秒間の脳波デ 一夕を $4-35 \mathrm{~Hz}$ の周波数帯域を時間周波数分析後, ボ タン押し後と FB 前の 3 秒間のアルファ波帯域(8-13 $\mathrm{Hz})$ とベータ波帯域 $(14-30 \mathrm{~Hz})$ 対して, 指定した 時間幅と周波数帯からの信号源の推定を行った (Beamformer 分析)。分析するデータには、ハイカッ トフィルター $(30 \mathrm{~Hz})$ と EOG コレクションをかけ た。実験に参加してもらった 20 名の被験者のうち, アーチファクトの混入が少なく 50 回以上加算でき る被験者のデータを分析に使用した。

\section{【結果と考察】}

時間周波数分析の結果は, BP と FB の区間を中心 に観察する。聴覚 FB 刺激条件では, 前頭と側頭と 後頭エリアでの $\alpha$ 帯域の脱同期があった。前頭エリ アでの $\beta$ 帯域での同期が見られ, また左半球に多く その活動があった。一方、視覚 FB 刺激条件では, 聴賞 FB 刺激と比べ， $\alpha$ 帯域の抑制は少なく, 頭部 の全体に渡り， $\beta$ 帯域での同期が多く観察された。

この分析後, Beamformer を用い, FB 前 $700 \sim 800 \mathrm{~ms}$ 区間の指定された周波数帯域からの信号源の再構成 を行った。SPN は FB 前に出現するため, 信号源の 推定は FB 前の区間に限定した。聴覚 FB 刺激条件で は, $8-12 \mathrm{~Hz}$ 帯域（抑制）の信号源は右の下後頭回 （BA8）付近, 22-30Hz 帯域（活動）の信号源は, 右の下前頭回（BA46）, 左の中前頭回（BA46）付近 と推定された。視覚 FB 刺激条件では, 8-13Hz 帯域

（抑制）の信号源は左の舌状回（BA18）付近に, 24-30Hz 帯域（活動）の信号源は両側の下頭頂小葉 （BA40）付近に推定された。時間周波数解析の結果 が聴覚FB 刺激と視覚FB 刺激条件で一致しなかった ことは, 異なる刺激様式での SPN の電位分布に違い が見られたこと (Ohgami et al., 2004; Brunia et al., 2004）と関係づけられる。聴覚 FB 刺激での両側前 頭部、視覚 FB 刺激での両側後頭部に信号源が推定 されたことは, 聴覚 FB 刺激時には後頭部と比べ前 頭部が有意に活動していたという Ohgami et al. (2004)の結果と一致する。 
ギャンブル課題遂行時の動機付けと SPN

○竹内成生 (国立身体障害者川ハビリテーションセンター)

正木宏明 (早稲田大学スポーツ科学学術院)

望月芳子 (早稲田大学大学院人間科学研究科)

高澤則美 (江戸川大学社会学部)

山崎勝男 (早稲田大学スポーツ科学学術院)

\section{【目的】}

感情一動機的な変化が, ギャンブル課題遂行時の刺激前 陰性電位 (SPN) に与える影響を検討した。

\section{【方法】}

被験者: 右手を常用手とする成人18名 (23.8 3.4.歳)。

課題: 被験者は2000円の所持金を元にコンピュータを相手と した対戦型ギャンブル課題を遂行した。被験者は注視点の $300 \mathrm{~ms}$ 間呈示後に, 右手示指と中指のボタン押しで賭け金 額を選択した(示指: 10円賭け, 中指:50円賭け)。ボタン押し に伴い選択した金額が白枠内に $2500 \mathrm{~ms}$ 表示された。相手 カードの種類が枠内に3000 ms表示された後, 勝敗を決定 する自身のカードが枠内に $700 \mathrm{~ms}$ 表示された。使用したカ 一ドの種類し強さは, Jack < Queen < King < Ace < Joker で あり, 対戦相手のみがJokerを所有することとした。手持ち力 一ドが相手カード以上であった場合を勝ちとし, 相手カード を下回った場合を負けとした。総試行回数は32試行 $\times 207 ゙$ ロックの計640回とした。統制条件として, 相手, 自身のカー ドが常に引き分けとなり, 金銭報酬が与えられない試行を64

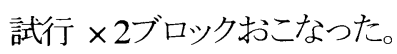

記録方法:脳波 (EEG) は, 国際10\%法に準拠した28部位 (FP1, Fpz, Fp2, F7, F3, Fz, F4, F4, F8, FC5, FCz, FC6, T7, C3, Cz, C4, T8, CP5, CPz, CP6, P7, P3, Pz, P4, P8, O1, Oz, O2) か ら左耳垂 (A1) を基淮に, 時定数 $10 \mathrm{~s}$, 高域遮断周波数 100 $\mathrm{Hz}$ で導出した。測定事象はサンプリング周波数 $250 \mathrm{~Hz}$ で保 存し, オフライン処理に供した。

分析方法: 行動指標は, 先行試行の結果と当該試行での選 択金額による反応時間, および先行試行の結果とリスク選択 率とした。心理指標は, 選択金額とその結果による主観的評 価とした。SPN は, ボタン押し反応をトリガとして, 直前試行 の結果と当該試行の選択によって加算処理した。加算波形 は, $10 \mathrm{~Hz}$ の low-passフィルタに供し, 統制条件を減じた。ボ タン押しの-200 ms から $0 \mathrm{~ms}$ をベースラインとし, 先行試行 の結果(4: Won50, Won10, Lost10, Lost50) ×当該試行での 選択金額 $(2 ;$ Choice50, Choice10) $\times$ 左右 $(2 ; \mathrm{L}, \mathrm{R}) \times$ 部位 (6; F, FC, C, T, P, O) を要因配置とした分散分析に供した。

\section{【結果】}

行動指標: 反応時間, リスク選択 (50 円を賭ける)率ともに有 意差は認められなかった。

心理指標: 先行試行が当該試行へ与える動機づけを検討す るために, 主観的評価(嬉しい一悔しい)について選択金額 と先行試行の結果を要因とした分散分析をおこなった結果, 50 円獲得した場合は他の損得結果と比較して有意に評価 が高まった( $\mathrm{F}(3,51)=20.78, \mathrm{p}<.001)$ 。

$\underline{\mathrm{SPN}}$ : 相手カード呈示直前の SPN 振幅值を検討した結果, 電極部位と選択金額に交互作用が認められ( $\mathrm{F}(5,85)=3.69$, $\mathrm{p}<.05), 50$ 円選択時に $\mathrm{F}>\mathrm{FC}, \mathrm{T}$ および $\mathrm{C}>\mathrm{P}(\mathrm{ps}<.05)$ の 関係を示した。Frontal で10 円選択時に比べ50 円選択時に 増大した(p<.05)。また, 先行試行の結果と選択金額にも交 互作用が認められた $(\mathrm{F}(3,51)=3.89, \mathrm{p}<.05)$ 。当該試行 50 円選 択時, 先行試行の結果が 50 円獲得した場合の SPN は, 他 の先行試行結果の場合より増大した(ps<.05)。さらに先行試 行で50円獲得した場合のみ, 当該試行選択金額によるSPN 振幅值に差が認められた(50yen > 10yen)。次に勝敗決定直 前のSPNについて検討した結果, 振幅值は Central で最大 を示 $(F(5,85)=5.68, p<.001)$, 電極部位と選択金額との交互 作用が認められた $(\mathrm{F}(5,85)=7.80, \mathrm{p}<.001) 。 10$ 円選択時と比 べ, Frontal で50 円選択時に振幅が増大し, 反対に Occipital では低下した(ps<.05)。また先行試行の影響も認められ $(F(3,51)=3.01, p<.05)$, 先行試行で10 円損失した場合に比べ, 50 円獲得した場合に振幅値は上昇した $(\mathrm{p}<.05)$ 。

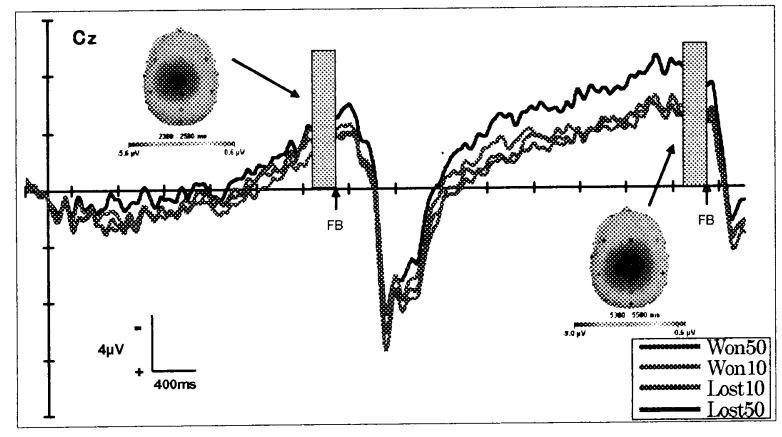

図 50 円選択時の先行試行結果ごとの波形推移

\section{【考察】}

50 円獲得後に主観的評価は高まり, 反応時間, リスク選択 率の回避的行動が生じていないことから, 次試行において 接近一動機づけが高まることが推察された。また, 先行試行 で50 円獲得かつ 50 円選択時, 相手カード呈示直前および 勝敗決定直前のSPN は上昇した。高額選択時に SPN は Frontal で上昇した。以上から, SPN は前頭を中心として, 接 近一動機づけの高まりを反映することが示唆された。 
他者エラーの観察に伴うエラー関連陰性電位の機能的 意義

○正木宏明 (早稲田大学スポーツ科学学術院)

入戸野宏 (広島大学大学院総合科学研究科)

高澤則美（江戸川大学社会学部）

山崎勝男（早稲田大学スポーツ科学学術院）

\section{【目的】}

エラー関連陰性電位(error-related negativity: ERN)は, 他 者のエラーを観察したときにも生起する。ERN の機能的意 義については, 包括的エラー検出仮説 (generic error-detection hypothesis:ED 仮説)之, その発展型の強化学 習仮説(Reinforcement-Learning hypothesis: RL 仮説分が提足昌 されてきた。両者の概念は類似しているものの，他者エラー が自分に正の報酬をもたらし，他者の正反応が自分に負の 報酬をもたらす事態下では，両仮説の予測結果は異なる。 ここでは，他者エラーが自分にとって不利益(金銭損失)とな る条件(WinWin 条件)と, 他者エラーが自分に利益(金錢獲 得)となる条件(WinLose 条件)を比較することで，他者エラ 一に惹起される ERN の機能的意義を検討した。

ED 仮説は, WinWin, WinLose の両条件ともに, 他者エラ 一の観察によって ERN が茩起されると予測する。一方，RL 仮説は, WinLose 条件では，他者の正反応時によって ERN が惹起されると予測する。

\section{【方法】}

被験者:大学生および大学院生14名 (平均年齢:20.6歳)。 フランカー課題: 注視点 $(+)$ 呈示後に, 一致(》》》》, 《《くく)または不一致刺激(》邓く》, 《くくく)が等確率でラン ダム呈示された。課題は，中央刺激の方向に対して反応寸 ることだった。制限時間400msをオーバーした場合には“Too Late!"が表示された。

Self条件: 被験者自らがフランカー課題を遂行した。正反応 毎に10円の報酬を獲得し，エラー毎に30円が減゙られた。

WinWin·WinLose条件:別室でフランカー課題を遂行してい る他者のパフォーマンス(コンピュータによるシミュレーショ ン)を被験者にモニタ上で観察させた。その際, 正誤結果が 容易に判別できるよう，中央刺激(く, >)だけを表示した。他 者の反応は刺激の左右に表示される青色正方形によって示 された。inWin 条件では，他者の正反応毎に 10 円の坏酬 を得たが(WinWin-Gain), 他者エラーによって30円減算され た(WinWin-Lose)。一方, WinLose 条件では, 他者の正反応 によって 10 円が減算され(WinLose-Loss), エラーによって
30 円の報酬艺得た(WinLose-Gain)。被験者は他者のエラー をカウントた。他者のエラー率は25\%に制御た。

条件の順序はSelf条件遂行後に, WinWin条件とWinLose 条件を行った(2条件は被験者間でカウンターバランス)。各 条件とも，40試行×10ブロック遂行された。

記録方法:EEGは頭皮上128筫所からDC 記録した(Biosemi, Active Two)。垂直·水平EOGも同様に導出した。Self条件で は被験者のエラー反応時点で脑波を加算平均して反応 ERNを算出した。WinWin, WinLose条件では, 他者の反応 時点を小川ガに脳波を加算平均した。 ERP波形には時定数 $1 \mathrm{~s}$, ローパスフイルタ10Hzを適用した。ERP振幅は刺激前200ms 電位を基楾に200ms-240msの区間平均電位を計浿した。

Self条件: 平均反応時 間は, 一致刺激 $<$ 不 一致刺激だった $(t$ (13) $=9.66, p<.001)$ 。 エラー率は, IC $>\mathrm{Cだ}$ った $(t(13)=8.77$, $p<.001)$ 。エラー反応 時にFCZ最大のERN が観察された。右図は WinWin, WinLose 条 件でのERP総加算平 均波形 $(\mathrm{FCZ}, \mathrm{N}=11)$ で ある。WinWin-Gainに 比較して, 他条件では 潜時200-250msで陰性 【結果】

成分が観察された。FCzとC2の振幅值について1要因分散 分析を行った結果, FCZでは差はなかったが, C2に有意差 がみられた $(\mathrm{F}(3,30)=4.91, \varepsilon=.46, p<.05:$ WinWin-Loss > WinLose-Loss $(p=08)$,WinLose-Gain $>$ WinWin-Gain $(p<.05)$, WinLose-Gain $>$ WinLose-Loss $(p<.01)$ )。

\section{【考察】}

FCz では WinWin-Gain を除く条件で, 潜時 200-250msに 陰性成分が観察され，ED 仮説，RL 仮説のいずれの予測と も合致しなかった。しかしながら，WinLose-Gain， WinWin-Loss の陰性成分は, WinLose-Loss と頭皮上分布が 異なったことから，ERN ではなく標的検出処理に関連した $\mathrm{N} 2 \mathrm{c}$ 成分の可能性が高い。統計的に支持されなか力たもの の, WinLose-Loss (他者の正反応) の陰性成分惹起は, RL 仮説の予測に反しないと考えられる。 
記憶課題における锶察者の存在が課題遂行および ERP に 及ぼす影罍について

\section{○平工志穂 (東京大学大学院棇合文化研究科) \\ 織田弥生 (東京工業大学大学院社会理工学研究科) \\ 小谷泰則 (東京工業大学大学院社会理工学研究科) \\ 石井源信 (東京工業大学大学院社会理工学研究科)}

他者の存在がパフォーマンスに与える影響について 様々な研究が行われているが，課題実施時の脳機能に与 える影響はまだ不明な点が多い。本研究では記憶課題を 用いて, 観察者の存在の効果について ERP を指標に検討 を行う。

方法

被験者: 男子大学生及び大学院生 (全員右利き) 20 名。 課題 (図 1): 実験用ソフトE-prime を用いて, 参加者 の前方約 $1.5 \mathrm{~m}$ に設置した 15 インチの液晶ディスプレイ 上に記憶課題を呈示した。被験者は画面上に 5 秒間呈示 される 3 文字の英単語とアルファベット 1 文字の組み合 わせ 5 組を記憶する。呈示終了の 3 秒後に英単語が呈示 される (3秒間) ので, どのアルファベットとペアであっ たかを 3 択で手元のボタンを押し回答する。回答 3 秒後 に回答の正誤と反応時間が画面上でフィードバックされ る。以上を 1 試行とし， 1 セット 30 試行行う。なお， 3 択の呈示時間は, 実験前に行なった練習課題の成績によ り, 参加者ごとに $3000 \mathrm{msec}$ から増減させて決定した。

生理指標 : 電気生理指標（脳波, 眼球運動, 筋電図, 心電図）を脳波計（SYNAFIT 5800）を用いて同時記録 した。

脳波は電極キャップ (Electro-Cap International, Inc.) を用い，拡張 10-20 法により 25 部位（Fp1，Fp2，F3， $\mathrm{F} 4, \mathrm{C} 3, \mathrm{C} 4, \mathrm{P} 3, \mathrm{P} 4, \mathrm{O} 1, \mathrm{O} 2, \mathrm{~F} 7, \mathrm{~F} 8, \mathrm{~T} 3, \mathrm{~T} 4$, T5, T6, Cz, Fz, Pz, FCz, CPz, CP3, CP4, FC3, FC4）より時定数 10 秒，ハイカットフィルタ $30 \mathrm{~Hz}$ で測 定した。筋電図（EMG）は右前腕（尺側手根屈筋）から 時定数 0.03 秒で導出した。

条件:単独条件(Alone) と被観察条件(Observed) を設け

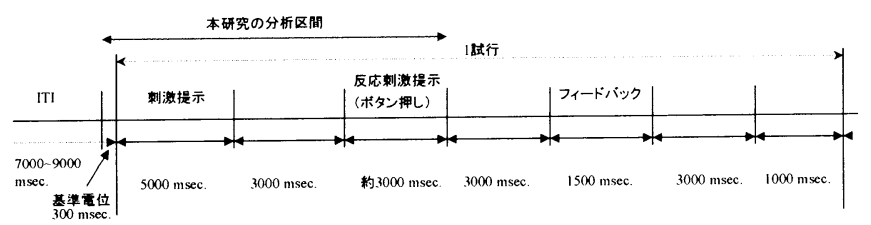

困 1 記憶課題
た。単独条件では被験者が一人きりで課題を遂行した。 被観察条件では 2 名の観察者が注意深く観察している中 で課題をおこなった。観察者は被験者の面識の無い異性 (女性)で，白衣を着用し，バインダーを持ち，被験者前方 で静かに観察を行った。各条件とも課題を 2 セットずっ 行った。試行順序は被験者間でカウンターバランスを取 つた。

手続き：(1)質問紙記入，練習，電極貼付(約 90 分)，(2) 安静 (10 分), (2)1 つ目の条件 2 セット(30 分), (3)休喆(30 分), (3) 2 つ目の条件 2 セット(30 分)の順で実施した。各 条件の前後（合計 4 回), 情動・覚醒質問紙への記入を求 めた。

分析 : EEG 等はVital Tracer、EPLYZE II を用いて分 析, 加算平均等の処理をした。今回はF3, F4, C3, C4, P3, $\mathrm{P} 4, \mathrm{Fz}, \mathrm{Cz}, \mathrm{Pz}$ 部の $\mathrm{EEG}$ について, 記憶課題提示前 $300 \mathrm{msec}$ より呈示後 $12000 \mathrm{msec}$ までを分析の対象とし た。 ERP の基線は記憶課題呈示前の $300 \mathrm{msec}$ 間の平均 電位とした。

結果と考察

単独条件と被観察条件の $\mathrm{C} 3, \mathrm{Cz}, \mathrm{C} 4$ 部における, $\mathrm{EEG}$ 分析可能な 18 名の被験者の加算平均波形を図 2 に示寸。

中心部に限らず，全頭的に記憶課題呈示時は被観察条 件のほうが陰性方向への電位水準が高い傾向が見られた。 反応刺激呈示までの CNVについては左右差が観察され, $\mathrm{C} 3$ などの左半球測定部位では単独条件で，C4 などの右 半球測定部位では被観察条件で高い陰性電位が観察され た。

\section{観察者の存} 在が記憶課題 実施時の脳機 能に影響を与 えることが示 唆された。

今後, 他の $\mathrm{ERP}$ ○影響, 脳波や心理検 查等との関係 を検討してい く予定である。

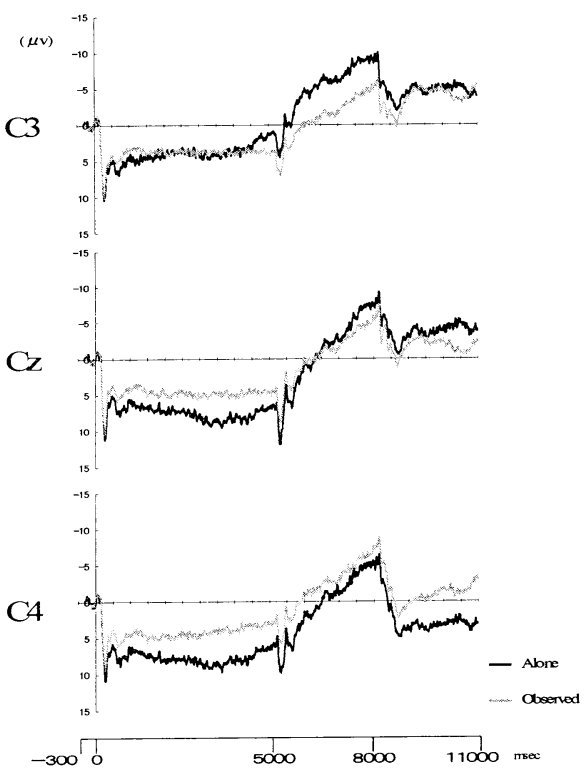

図 2

$\mathrm{C} 3, \mathrm{Cz}, \mathrm{C} 4$ 部の各条件の加算波形 


\section{反社会性人格㑯向と事象関臬而位の特徽}

○福田 一彦 (福島大学共生システム理工学類)

殺人罪で告訴されている被疑者では対照群より前頭葉 外側、内側での脳糖代謝が有意に低下しているという報 告 (Raine et al., 1994) や、反社会性人格障害 (ASPD) の患者の前頭葉内での脳血流量が低下しているとする報 告 (Kuruogle et al., 1996) や、ASPD 患者において前頭 葉の事象関連電位 (P300) の振幅が有意に減少している とする報告 (Costa et al., 2000) など、反社会的もしくは攻 撃的な行動と前頭葉の機能不全との関係を示唆する研究 が多く存在する。本研究は事象関連電位を用いて上記と 同様の傾向が健常若年成人を対象としても認められるか 否かを確認することを目的とした。

\section{研究 1 (反社会的行功尺度の潇成):}

方法：大学生 264 名を対象として調査を行った。調査項 目は、DSM-III-R 及びDSM-IV の反社会性人格障害の診 断基準加 22 項目、ICD-10 の反社会性人格障害の診断 基準から 8 項目、MMPI の Pd(精神病質性偏倚) 尺度より 50 項目、日本版 Buss-Perry 攻撃性検査より 24 項目を選び これらに対して 5 件法により回答させた。質問には不快感 を感じさせる項目が含まれることから、回答は任意とした。

結果：以上のうち日本版 Buss-Perry 攻撃性検査を除く全 ての項目を対象に、回答に不備のあった 27 名を除く 237 名のデータを用いて因子分析（主因子法、Varimax 回転） を行い、最終的に 2 因子を抽出した。項目の内容などから、 第 1 因子を攻撃性 (Aggressiveness)、第 2 因子を情緒性 の希薄さ (Emotional Detachment) と命名した。この2因子 は Blonigen et al. (2002) が PCL-R (The Psychopathy Checklist-Revised / 精神病質チェツクリス卜) を因子分析 した結果導き出された 2 因子と類似しており、このことから も ASPD の症状の 2 因子構造はある程度、普遍性を持つ と考えることが出来、かつ、それは、一般健常者を対象と した今回の研究でも同様の構造を示すことが明らかとなっ た。従来、ASPD と前頭部機能不全とが関連しているとさ れてきたが、この結果より、「攻撃性」と「情緒の希薄さ」の いずれが、もしくは両方が関与しているのかを検討する必 要があると考えられた。

\section{研究 2(反社会的行動と事象関連而位)：}

方法：研究 1 により構成された「攻撃性」尺度と「情緒性 の希薄さ」尺度の得点により以下に述べる特徵を持つ大 学生 20 名(各群 5 名)を被験者とした。1) 高攻撃性·高情
緒性希薄群 (男性 2名、平均年齡 19.9歳)、2) 低攻撃性・ 高情緒性希薄群(男性 0 名、平均年齢 19.8 歳)、3) 高攻 撃性·低情緒性希薄群（男性 3 名、平均年齢 18.7 歳）、4) 低攻擊性·低情緒性希薄群 (男性 2 名、平均年齢 18.5 歳)。 前頭部優位のP3 を誘発するため、通常の Oddball 課題に、 標的に類似した非標的刺激を追加し、3 種類の視覚刺激 （target：出現率 0.15, 赤い円、non target frequent: 出現 率 0.7, 黒い円、non target rare: 出現率 0.15 , 赤い正三角 形・または赤い正方形)を用いた。刺激の呈示時間は 60 $\mathrm{ms}$ 、刺激間間隔は $1600 \mathrm{~ms}$ で無作為な順序で呈示した。 脳波は両耳架を短絡したものを、基準電極とし、国際式 10-20 法に従い、Fz, Cz, Pz, F3, F4, C3, C4, P3, P4, O1, O2, F7, F8, T5, T6 の 15 部位から記録した（帯域フィルター： $0.05 \sim 30 \mathrm{~Hz}$ )。さらに、垂直眼球運動を監視するため、左 眼窩上下より垂直眼球運動を記録した。脳波と垂直眼球 運動は、サンプリング周波数 $200 \mathrm{~Hz}$ で A/D 変換を行った。 結果：「攻撃性」の高い被験者は、前頭部から中心部の 特に右半球において P3 の振幅が低下している傾向が認 められ、nontarget frequent 刺激に対して、F8においては、 P3 の面積に攻撃性の低い被験者との間に有意差が認め られた(Fig. 1)。この傾向は、標的刺激においても非標的 刺激においてもほぼ同様であった。多くの研究が攻撃性 と右半球の機能不全との関係を報告している (Raine, 2002) が、今回の結果はこれらの報告を支持する内容で あると考えられた。一方、反応時間や正反応率などの行動 指標には、統計的に有意な差が認められなかったが、反 応時間の分散(標準偏差)に関して攻撃性の高い被験者 で小さい傾向が認められた $(t(18)=1.758, \mathrm{p}<0.1)$ 。
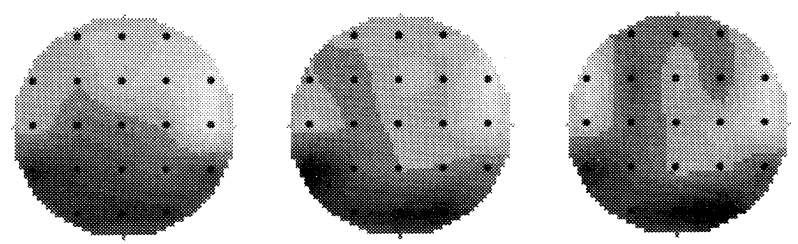

Fig. 1 Topography of P300 and aggressiveness: Relative suppression of P300 amplitude was greater in right anterior region. Responses to target, non target rare, and non target frequent were presented from left to right, respectively. 
Tsukuba 低㑲動系ラットの多到烦向と嵒内の形態学 的変容との関連について

O吉田 和典 (仁愛大学人間学部心理学科)

目的

これまで Tsukuba 情動系ラットの中で特に, 低情動 系ラットの多動傾向が指摘されてきた。しかしながら， 発達過程と多動性との関連に関しては未だ不明な点 が多い。またこれらの多動傾向の背景となる脳内の メカニズムに関しても明らかとなっていない。そこで, 本研究では, 様々な発達段階での Tsukuba 低情動系ラ ットのオープンフィールド行動を詳細に観察すると 同時に, 脳内特に黒質ニューロンの動態を形態学的に 険索し, Tsukuba 高情動系ラットと比較検討すること を目的とした。

\section{方法}

被験体は, $12: 12$ 時間の明暗条件下（午前 8 時よ り午後 8 時までが明期) で飼青された $30 ， 60 ， 90$ 日 齢の Tsukuba 低情動系（L系）及び高情動系（H系） ラットで, 雨群の各日龄各々雄 6 匹, 雌 6 匹の㖕 72 匹を用いた。これらの情動系ラットは，82 世代目の ものを筑波大学心理学系よりに譲り受け, 仁愛大学で 兄妹交配し 86 世代目となったものを用いた。装置は, 内径 $80 \mathrm{~cm} \times 80 \mathrm{~cm}$, 高さ $30 \mathrm{~cm}$ の自製のオープンフィ ールドを用いた。内側は $20 \mathrm{~cm} \times 20 \mathrm{~cm}$ の正方形 16 区画で区切られている。この区画の中心をスタート地 点とした。オープンフィールドの中央にラットを置き, 5 分間の通過区画数, Rearing, Sniffing, Grooming,

Face washing, 脱亚, 脱尿の回数を記録するととも に, ビデオ録画した。なお, 通過区画数は尻尾の付け 根部分の通過を基淮とした。 Rearingについては，壁 に前足をかけ立ち上がっている状態のものも含めた。 Sniffingにおいては, 走行中のものは省き, 完全に止 まった状態でのみ記録した。ビデオ録画に基づき，す ベてのラットのオープンフィールド内での走行軌跡 から走行距離を算出した。実験終了後, ネンブタール 深麻酔下で, 脳を灌流固定し, $30 \mu \mathrm{m}$ の連続凍結薄切 片を作製し，一枚每にニッスル染色とチロシンハイド ロキシラーゼ $(\mathrm{TH})$ 免疫染色を行なった。TH 免疫抗体 法は，作製した㵝切片を TH 抗体(10000 倍希䣋)溶液 内で 3 日間浸し $\left(4^{\circ} \mathrm{C}\right)$, 次に, 二次抗体のビオチン
化 anti-rabbit IgG 溶液内で 12 時間浸した $\left(4^{\circ} \mathrm{C}\right)$ 。 その後, $\mathrm{ABC}$ キットを加えた溶液内で 2 時間浸し(室 温)，最後に，DABによる HRP 反忘を行った。

\section{結果及び考察}

図 1 はオープンフィールド内での 5 分間の走行軌 跡から平均走行距離を算出したものである。図から明 らかなように，L系ラットはH系ラットに比べて有意 に活動量が多く（数倍以上），従来から言われている 明瞭な多動性が確認された。その中でも特に 30 日齢 L 系ラットが 60 日齢や 90 日齢 L 系ラットより多動傾 向が有意に高く，L 系ラットにおいても発達に伴い多 動性の減少が認められた。すなわち，90 日齢 L 系ラ

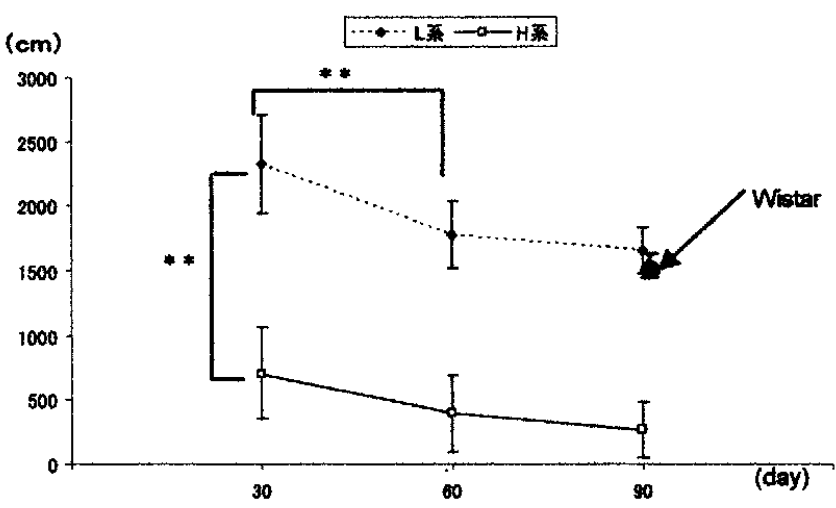

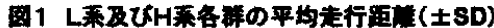

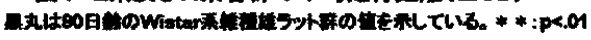

ットは，同日齢のWistar 系雑種ラットとほぼ同じ值 であったことから, 成熟に伴いL 系ラットの多動性は 改善してくるものと考えられる。そこで，これらのL 系ラットの多動性と脳内の形態学的変容との関連を 詳細に調べた結果, 30 日跲 $\mathrm{L}$ 系ラットにおいて, 吻 側部の黒質繳密部領域の萎縖が顕著に生じていた。ま た, 黒質緻密部ニューロン群の减少と共に, TH 免疫 染色法により TH 陽性ニューロンの堿少㑯向も認めら れた。従って，黑質繳密部一線条体系ドーパミンニュ 一ロンが，30 日齢 $\mathrm{L}$ 系ラットにおいて特異的に减少 していることが判明した。これらのし系ラットの黒質 部位での形態学的変容は, その後成熟するにつれて回 復傾向が認められた。以上のことから，30 日跉 L 系 ラットは，ヒトの幼児期にみられる $\mathrm{ADHD}$ の特性と類 似しており，動物モデルになりうると考えられる。

本研究の実施にあたり, 仁曼大学大学院生の梅田亜 沙子さんと梶本尚江さんに多大なるご協力いただい た。両氏に厚く感謝いたします。 


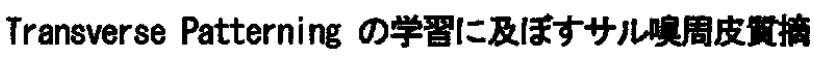

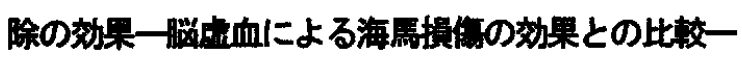

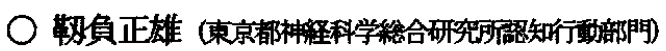

\section{I. 目的}

Transverse patterning 課題 (TPT) の学習は, 単純な 弁別課題のように正刺激そのものに報䊼や反忘との連合 を形成すれば解決する（要素連合）ものではなく，対呈 示される刺激の要素の複合に対して反応を形成する（構 成連合：configural association）とか対呈示される相 手の刺激によって柔軟に正刺激要素と反応を形成する (関係連合: relational association) と考えられ, ラ ットによる研究では海馬あるいは嗅周皮質が関与すると 報告されていた。しかし，昨年度本大会で報告したよう に，サル淨虚血による海馬損稘は TPT の学習に障害を与 えなかった。そこで，今回順周皮質を掊除したサルでTPT 学習に及ぼす効果を検討し，海馬損傷の効果と比較した。

\section{II. 力法}

被験体:ニホンザル4頭とアカゲザル2頭を使用した。 このうちニホンザル 3 頭は, 術前の遅延見本合わせ課題 の訓練の後，衡周皮質摘除(PRC)の手術を受けた。残り 3 頭は非摘除健常 (N) 群として同じ課題の訓練を受けた。 摘除ザルは手術後術前と同じ課題を再学習し，その後遅 延テストを受けた（統制群も同じ行動課題を同じ手順で 経験)。その後，両群のサルは本検討課題の TPT 学習の訓 練を受けた。うち統制群のアカゲザル1頭が実験途中で 死亡したため，前年度䋞虚血研究で $\mathrm{N}$ 群として使用した 3 頭のサルを今回の N 群に加え 5 頭とした。

実験装置 : 防音室に㯰かれた改良型ウィスコンシン式 一般テス卜装置 (WGTA) を使用した。

TPT 課題: これは, 3 枚の写真カード刺撽 $(6 \mathrm{~cm} \times 6 \mathrm{~cm})$ を1セットとし, 2 セット6枚 (セット $1: A, B, C$, セット $2: \mathrm{D}, \mathrm{E}, \mathrm{F})$ かららな 6 対の二者択一并別学習 $(\mathrm{A}+\mathrm{B}$ -, $\mathrm{B}$ $+/ \mathrm{C}-, \mathrm{C}+/ \mathrm{A}-, \mathrm{D}+/ \mathrm{E}-, \mathrm{E}+/ \mathrm{F}-, \mathrm{F}+/ \mathrm{D}-)$ で, 同じ刺 激が対となる刺激によって異なる刺激価を持つ。表 1 に 示すように，課題は 3 つの phase に分け段階的にサルに 与えた。各phase で12試行を 1 ブロックとしてそのphase の問題を等しい試行数を擬似ランダムに与え, 1 日4ブロ ック計 48 試行を訓練した。学習基淮は各 phase で各問題 連続 12 試行中 11 正反応以上をとることとし, 各対の成 績がその基淮に同時に達成することとした。学習基淮に 達すると次の phase に進んだ（昨年度抄録図参照）。
統制課題:TPT 課題の終了後, 統制課題として 12 枚の刺 激からなる 6 対の同時複式弁別課題 (CDT: Concurrent Discrimination Task）をTPP 課題と同様の手続きで与え た。

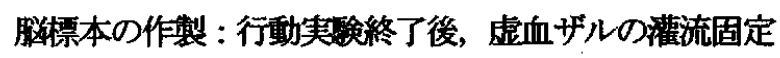
を深麻势 $(40 \mathrm{mg} / \mathrm{kg}$, 静注) 下で行い, $50 \mu \mathrm{m}$ の厚さの前 額断切片を作成し，ニッスル染色を施し，搝周皮質のお よび周囲の皮質の損賃域を調べた。

\section{III. 結果と考察}

組織学的結果 : 摘除ザル3頭において嗅周皮質の前端 部に取り残しを認めたが，概ね損甥されていた。他に一 部嗅内皮質, 後部海馬傍回, 下部側頭回 TE 野腹側部に損 傷が及んだ。

行動学的結果 : N 群柱, TPT の Phase1, 2, 3 をそれぞれ 平均 6.8,39.2,231 試行 (1 問題あたり) で学習基淮に達 したが, PRC 群はPhase 1 が 26, Phase 2 が 67.5 試行で 学習したのに, Phase 3 では全ての摘除ザルは600試行以 内で学習基淮に達しなかった。統計学的に群間と Phase の主効果と交互作用について有意差を示した [ANOVA, 群 閒 $F(1,18)=15.38, p<0.01$; Phase, $F(2,18)=84.81$, $\mathrm{p}<0.001$; 交互作用, $\mathrm{F}(2,18)=17.39, \mathrm{p}<0.001]$ 。群間で は Phase 3 のみで PRC 群の有意な成䋶の悪化が示され (Mann-Whitney のUテスト, $\mathrm{U}=0, \mathrm{p}<0.02)$, 他の Phase では有意差は無かった (Phase 1, U=2, p>0.07; Phase 2, $\mathrm{U}=3, \mathrm{p}>0.12)$ 。Tukey 法による Phase 間の成績の検定は, Phase 3 が他の二つの Phase との間に有意差を示した (p<0.01)。

CDT 課題ではN 群が各 Phase について平均 2.6, 6, 4.4 試行で学習基準に達したのに対して PRC 群はそれぞれ 17.6，10.3，21 試行で学習基淮に達成した。ANOVAによる 検定は群間に有意差を示した $[\mathrm{F}(1,18)=4.41, \mathrm{p}<0.05]$ が,UテストではいずれのPhaseにおいても群間に有意差 は喼められなかった $N$ 群のPhase 3 における TPT 学習の 過程は, Phase 1，2 において学習した問道の成績が低下 しないままに, 新たな問題の成績が最初の一定の期間の0 正反応から急速に上がるという特徴を示した。

本結果は, TPT 課題の学習に嗅周皮質が密接に関与する ことを示唆した。 N 群のPhase 3 における学習の特徽は関 係連合よりはむしろ構成連合による課題解決を反映して いると考えられる。従って，嚊周皮質は構成連合による TPT 課題の解决に関与しており，海馬は構成連合に関係し ないと考えられる。 


\section{ラットの遅延挿入放射状迷路課題の遂行に及ぼす 蛋白質合成阻害薬脳室内投与の効果 \\ ○中野 雅之一谷 幸男 \\ (筑波大学大学院人間総合科学研究科)}

先行研究において, ラット脳内における蛋白質合成 は, 記憶の固定・保持などの過程に関与することが, 受動的回避学習や恐怖条件づけを用いた実験で報告さ れている (Quartermain et al., 1970; Schefe \& LeDoux, 2000)。しかし, 空間的作業記憶については不明な点が 多い。本研究は, 空間的作業記憶のどの過程に蛋白質 合成が関与しているのか, 遅延挿入放射状迷路課題を 用いて検討することを目的とした。

\section{方 法}

被踰体:Wistar-Imamichi 系雄ラット42 匹を用いた。 峦 膡: 灰色塩化ビニル製の高架式 8 万向放射状迷路 を用いた。

薬 物：蛋白質合成阻害薬 Anisomycin (ANI)を, リン

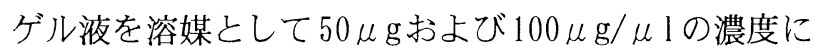
溶解した。薬物テストでは, 被験体の右側脳室内に 1 $\mu \mathrm{l} / \mathrm{min}$ で 2 分間, 計 $2 \mu \mathrm{l}$ 投与した。なお, ANI 200 $\mu \mathrm{g}$ 脳室投与による脳内各部位の蛋白質合成阻害を測 定した先行研究（Meiri \& Rosenblum，1998）では，投 与 15 分 45 分後, 海馬で $85 \%$ 以上の蛋白質合成の抑制 を示した。

群構成：薬物投与の夕イミングを課題前半開始の 30 分前 ( I 群), 前半終了值後 (II a 群), 前半終了から 2 時間後 (II b 群), および後半開始の 30 分前 (III群) とし, 被験体を各群にランダムに振り分けた。

手䌇き：1）ハンドリングと装置馴化を行い, 被験体 に標準的な放射状迷路課題を訓練した。次に，第 4 正 選択の後に遅延時間を㨂入し, 待機ケージで待機させ た後に第 5 選択以降を行わせるという手続きで遅延課 題を訓練した。遅延時間 0 分, 10 分, 6 時間の遅延課 題を順番に訓練した。2）麻酔下で脳定位固定装置を 用いて被験体を固定し，インジェクションカニューレ の先端が側脳室に達するようにガイドカニューレ埋め 込み手術を行った。3）術後 7 日間の回復期間をおき, 6 時間の遅延課題を再訓練した後, ANI 投与下で遅延課 題を行う薬物テストを行った。薬物条件は (1) 溶媒 2 $\mu \mathrm{l}$, (2) ANI $100 \mu \mathrm{g}$, (3) ANI $200 \mu \mathrm{g}$ とし, 各群の被 験体がランダムな順番で 3 条件全てを行った。4）薬
物テストを終えた被験体の脳を灌流固定し，インジェ クションカニューレの位置を組織学的に確認した。

\section{結 果}

最終的に 40 匹の結果を分析した。課題後半の平均 誤選択数をFigure 1 に示す。二要因分散分析の結果, 薬物投与のタイミング $\left(\mathrm{F}_{(3,36)}=7.99, p<.01\right)$ と薬物用 量 $\left(\mathrm{F}_{(3,108)}=2.85, p<.05\right)$ の主効果, および交互作用 $\left(\mathrm{F}_{(9,}\right.$, $\left.{ }_{108)}=2.00, p<.05\right)$ が有意であった。下位検定の結果,

I 群と群においてのみ, ANI 投与により誤選択数が 有意に増加した。誤選択は, 課題前半で選択したアー ムへの進入が大半で, 課題後半の中での重複選択はほ とんどなかった。

\section{考 察}

ANI 投与により, I 群とIII群において遅延課題後半 の誤選択数が増加した。また, 後半での重複選択によ る誤選択はほとんどなかった。よって, ラットの遅延 課題の遂行に必要な空間的作業記憶は，短時間ならば 蛋白質合成に依存しないが，長時間に渡る場合は蛋白 質合成に依存することが示唆される。また，I群は空 間的作業記憶の記銘または固定の過程で，III群は，検 索の過程で蛋白質合成を阻害したと考えられる。よっ て，長時間に渡る空間的作業記憶の記銘または固定, および検索の過程に蛋白質合成が関与することが示唆 される。

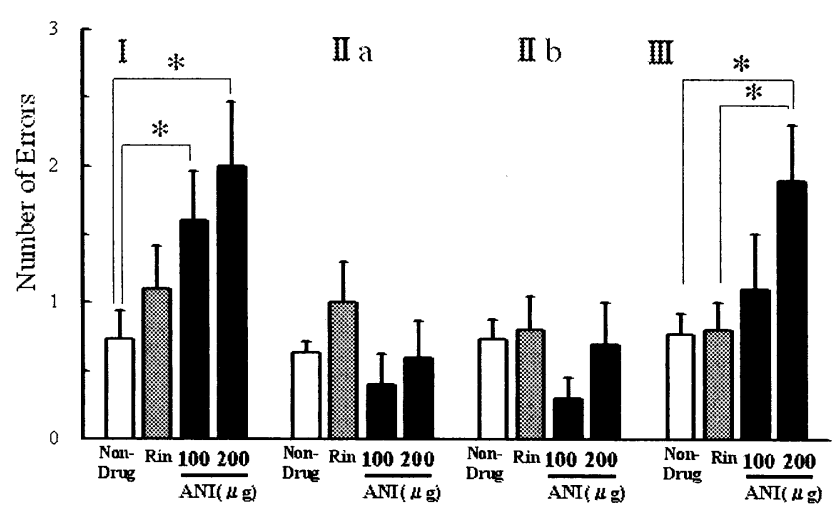

Figure 1 Mean number of errors ( \pm SEM) in the sec ond-half perforinance of delay-in terposed task. Rom an num erals indicate drug in jection timings. * in dicates significant difference $(y<05)$.

\section{引用文献}

Meiri \& Rosenblum 1998 Brain Res., 789, 48-55. Quartermain et al. 1970 Science, 169, 683-686. Schefe \& LeDoux 2000 J. Neurosci., 20, 1-5. 


\section{脳損傷者の認知機能評価に関するpsychometrics の再考}

(9)

\author{
一症例報告を中心にした脳画像併用による \\ 神経心理学的診断の試み一 \\ ○富永 大介 (琉球大学 教育学部)
}

脳損傷者の認知機能評価の方法として, 琉大式評価方 法を作成し，約15年ほど前から現在まで約3000名の脳損 傷者等の患者の検査データを得ている。この琉大式簡易 神経心理検査バッテリーは, 新しい認知機能検査を独自 に作成したものではなく，既存の検査を組み合わせて琉 大式ということで活用しているものである(富永，2005)。

このバッテリーの下位検查にStroop Test(ST)やTrail Making Test(TMT)がある。両検査とも前頭前野の実行機 能の成分を反映するとされる, これらの検査は脳損傷者 の認知機能障害等の評価にしばしば用いられる。しかし， これらの検查による遂行測度の評価で, 前頭葉性の認知 機能障害を正確に評価することが可能かどうか疑問で ある。なぜならば，その遂行速度とその程度が，認知障 害のどの成分を反映しているのか曖昧であり, 前頭葉性 の検査としても，その検查には前頭葉機能以外の知覚， 記憶機能の関与が当然考えられる。

本研究では, STとTMTの課題を脳損傷者患者に実施し, 遂行測度を含む遂行過程と損傷部位との関係を吟味す ることにより，両検査の臨床上での有効な活用法につい て論じる。

以下に, 脳損傷者に実施したTMTとSTの検查の特徵と 被験者群について述べる。

\section{[TMTとSPの特徴と検査結果の分析］}

TMT検査の特徵と検查結果の分析:

-3枚の図版加ら構成(数字図版, 仮名図版, 混合図版)

・非言語性の視覚探索課題の関与

- 各図版の遂行測度と注意指標(attention effect)の算出 $\mathrm{ST}$ 検査の特徵之検查結果の分析

・3枚の図版から構成(文字図版, 色図版,ストループ図版)

·言語性, 色の言語化

・各図版の遂行測度と抑制指標 (Stroop effect)の算出 [被験者群の特徴]

・琉大式簡易神経心理検査バッテリー検査を受けた脳腫 瘍，脳血管障害の患者群である。

以上の被験者群にTMT\&STを実施し, 症例をもとに両検査 の認知機能評価を報告する。
[結果及び考察］

1. TMTで右頭頂葉障害を示唆する所見 症例1381 女性59 右内頸動脈狭窄，右頭頂脳梗塞 神経心理検查 modified MMSE:94/100 MMSE:28/30

\begin{tabular}{|r|c|c|c|c|}
\hline TMT S-TMT & Num 61s & Kana 61s & Mixed 95s & 注意指標 34s \\
\hline 評価点 & $5 / 10$ & $6 / 10$ & $5 / 10$ & $8 / 10$ \\
\hline \hline Stroop & Kana 27s & Color 40s & Stroop 61s & 抑制指標 27s \\
\hline 評価点 & $7 / 10$ & $7 / 10$ & $9 / 10$ & $10 / 10$ \\
\hline
\end{tabular}

この症例のADL十分保たれている。TMT\&STの評点の結果 では，前頭葉性の注意指標 (TMT) と抑制指標 (ST) は同年 齢健常者水準を保っている。また, Stroop検査でのKana, Color，Stroopの反応速度は健常者レベルかそれに近い。 しかし，TMTの成績の低下が特徵的である。視覚探索空 間操作に困難を示す。画像では, 右頭頂葉に脳梗塞巣が みられる。

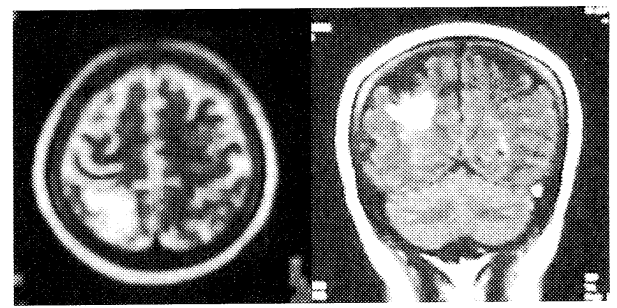

2. TMTで前頭葉障害を示唆する所見

症例1128 男性69 右内頸動脈狭窄 陳旧性脳梗塞(前頭頭頂葉)

神経心理検查 modified MMSE:90/100 MMSE:26/30

\begin{tabular}{|r|c|c|c|c|}
\hline TMT S-TMT & Num 74s & Kana 67s & Mixed 不能 & 注意指標 不能 \\
\hline \hline 評価点 & $6 / 10$ & $8 / 10$ & 不能 & 不能 \\
\hline Stroop & Kana 33s & Color 38s & Stroop 79s & 抑制指標 43s \\
\hline 評価点 & $8 / 10$ & $10 / 10$ & $7 / 10$ & $8 / 10$ \\
\hline
\end{tabular}

この症例のADLは十分保たれている。TMTの混合図版の 不能である。これは前頭葉性のattention shiftingの機能 欠損を示唆する。Num, Kanaの遂行が可能であることか ら，TMTでは，前頭葉性の機能低下が特徵であることを 示唆する。TMTとStroopの結果に乘離があることから， 非言語性の視空間が関与する右前頭葉性の障害といえ るか，今後の検討課題である。

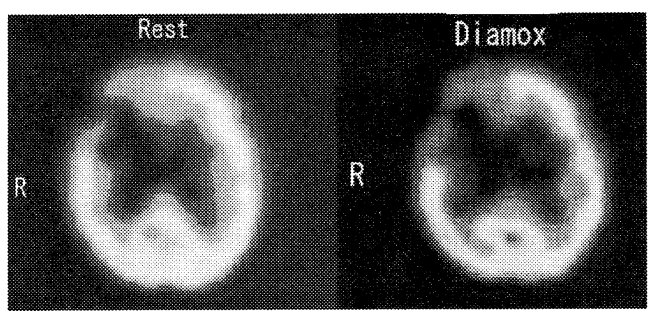

[本研究は H18 年度科学研究補助金 (課題番号 18530537)の助成を受けて 行われた]

富永大介 2005 脳障害者の認知機能評価に関するサイコメトリックス の再考 科学研究成果報告書 (15530457 平成 15 16 年度) 
情報の更新を必要とする視覚的作業記憶の保持と変化 検出に関わる神経基盤 - event-related fMRI 研究-

○高濱 祥子 (科学技術振貼機構)

宮内 哲 (情垠通信研究機構)

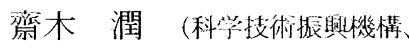

京都大学大学院人間・噮境学研究科)

視覚的作業記憶として脳内に保持された物体の特 徵に関する記憶表象と, 眼前の物体の知覚表象と照合 することによって，我々は一時的に物体が眼前から消 えたとさにも物体の同一性を判断することができる。 視覚的作業記憶の容量を検討するために考案された多 物体恒常性追跡（MOPT）課題（Saiki, 2003）では, 遮蔽により見え暚れする複数の物体が呈示され，実験 参加者は，遮蔽時に変化した属性の組み合わせの入れ 替えの検出, あるいは入れ替えタイプの同定を行った。 その結果, 視覚的作業記憶の容量は 1〜2 個であり,

色, 形などの特徵に基づく表象を必要に応じて結合さ せている可能性が示唆された。本研究では，単一属性

（色）情報と位置情報の結合の必要の有無に注目して 3 条件の MOPT 課題を用い, 動的な情報の更新を必要 とする状況における視覚的作業記憶の保持と変化検出 に関わる脳部位の特定を機能的 MRIにより試みた。

MOPT 課題のうち，4つのうち 2 つのターゲットが 灰色に替わるコントロール条件では，実験参加者は色 のリストやターゲットの位置情報を記憶しなくても課 題を遂行できる。それに対し，4つのターゲットのう ち 1 つが新奇な色と入れ替和る属性条件では，実験参 加者は色のリストを記憶しその情報を更新寸る必要が あるが, 位置情報の記憶と情報の更新は必要としない。

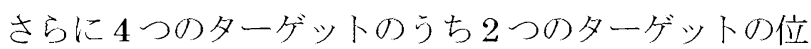
置が入れ替わる属性-位置結合条件では, 色のリストに 加えてターゲットの位置情報を記憶, 更新する必要が ある。

\section{【方法】}

実験参加者: 成人 13 名(21-42 歳, 男性 10 名, 女性 3 名)であった。

刺激: 7 色のうち，4 色の扇形ターゲットが放射状に配 置された。ターゲットが一定の角速度で（反）時計回 りに回転し, 静止した黒色の遮蔽板により遮蔽された。 刺激の中心に灰色のアルファベットが呈示され， 1 試 行のうち，1 可視期閒のみに生じる色の入れ替わりを
示した：コントロール条件(2つのターゲットが灰色に 替和る)，属性-位置結合条件(2つのターゲット間で色 が入れ替わる), 属性条件(1つのターゲットが新奇な色 に替わる）。実験参加者は色の入れ替わりを，ボタンを 押して報告するよら求められた。

手続き: MR スキャナの外で練習を行い実験参加者の 正答率がプラトーに達したことを確認した後, fMRI 実験を 10 セッション（16 試行/セッション）行った。 撮像と解析: 3T-MRI スキャナー (Siemens 社製 Trio) を用いて 1 セッションあたり 256 スキャン撮像した。 撮像条件は，TR=2000ms, FOV=192mm2，34axial slices, 解像度 $3^{*} 3^{\star} 4 \mathrm{~mm}$ であった。脳機能画像解析 にはSPM2 を用いた。

\section{【結果と考察】}

行動デー夕: $\mathrm{fMRI}$ 実験中の MOPT 課題の平均正答率 について分散分析を行った結果，条件の主効果が有意 であった $(\mathrm{F}(2 / 24)=31.56, \mathrm{p}<.01)$ 。さらに下位検定を 行った結果, 属性-位置結合条件の正答率が最も低かっ た $(\mathrm{p}<.05)$ 。

fMRI データ：トラッキングや変化検出に関する先行 研究(Culham et al., 1998; Pessoa \& Ungerleider, 2004) と同様，前頭葉-頭頂葉の広範な神経基盤が関与 することが示唆された。動的な更新を必要としない場 合と比較すると, 右半球に加え左半球にも賦活部位が 観察された。右半球の関心領域の信号值について分散 分析を行い，以下の結果が得られた。

<保持期間 $>$ 属性-位置結合条件では, 視覚的作業記憶 課題の符号化，固定に関与することが報告されてきた

(Druzgal \& D'Esposito, 2003; Leung et al., 2002;

Marois et al., 2000; Todd \& Marois, 2004）外側前頭 前野，上側頭回，頭頂閒溝，下頭頂小葉などにコント ロール条件と比較して有意な賦活がみられた。属性条 件では, コントロール条件と比較すると外側前頭前野, 上側頭回，頭頂閒溝に有意な賦活がみられた。

<変化検出 > 属性-位置結合条件で, 外側前頭前野上側 頭回，下頭頂小葉に加え，前頭前野前部でコントロー ル条件よりも有意な賦活がみられた。

以上のことから, 視覚的作業記憶内の情報を動的に 更新寸る必要がある状況では，上側頭回，下頭頂小葉 において属性と位置の情報を維持し, 変化の検出には， 維持に関わる脳部位に加えて前頭前野前部が重要な役 割を果たすことが示唆された。 


\section{脸血流からみた視覚性連続遂行課題 (CPT) 時の 前頭前野活動}

$\begin{array}{rll}\text { O水谷 } & \text { 勉 } & \text { (茨城大学教育学研究科) } \\ \text { 篠田 } & \text { 晴男 } & \text { (立正大学心理学部) } \\ \text { 軍司 } & \text { 敦子 } & \text { (国立精神・神経センター) } \\ \text { 尾崎 } & \text { 久記 } & \text { (茨城大学教育学部) }\end{array}$

\section{I . 問題}

連続遂行課題 (Continuous Performance Test) 遂行 には前頭前野が関与しているが，標的刺激の呈示確率 を変えると前頭前野の活性化領域が変化することが報 告されている（Casey et al. ，2001）。このことは, 反応制御を担う前頭前野の活動が，CPT に含まれる認 知的課題条件によって左右されることを示唆している。 そこで本研究では, 標的刺激の呈示確率が高い条件 (Frequent 条件) と低い条件（Rare 条件）での CPT 課題下での 脳活動を NIRS (Near infrared-spectroscopy) を用いて計測し, 反応制御と 関わる前頭前野の機能状態について検討した。

II. 方法

対象者: 右利き健常成人 11 名と左利き健常成人 1 名 (平 均 22.2 歳）。視覚刺激 : 眼前 $60 \mathrm{~cm}$ のノートパソコ ン画面中央に, 黒色を背景として縦 $4 \mathrm{~cm} \times$ 縦 $3 \mathrm{~cm}$ の数 字“1”または“2”を緑字で $200 \mathrm{~ms}$ 間呈示。課題 :

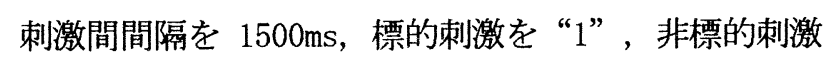
を“2”とする CPT-X 課題で，呈示された刺激が標的の ときには素早くボタン押しをするよう求めた。実験で は，(1)標的刺激の呈示確率が 84\%（Frequent 条件）, (2)標的刺激の呈示確率が 16\% (Rare 条件) を設定。い ずれの条件とも 100 刺激からなり,所要時間は $172 \mathrm{sec}^{\circ}$ NIRS 計測：NIM 社製 COGNOSCOPE（米国）のプローブフ オルダーを，国際 10-20 法の Fp1 が下段の L2 に，Fp2 が下段の R2 になるよう前頭部左右水平方向 8 箇所から 計測。正中線から L4 ならびに R4 までの距離は $8 \mathrm{~cm} 。$ 課題前 $30 \mathrm{sec}$ をベースラインとして課題中の $0 \mathrm{xy}-\mathrm{Hb}$ および Deoxy-Hb を計測。分析 : Frequent 条件およ び Rare 条件における課題前 $30 \mathrm{sec}$ から課題開始後 $165 \mathrm{sec}$ までの各 $15 \mathrm{sec}$ 間の平均 $0 \mathrm{xy}-\mathrm{Hb}$ 量を算出し, 各時間帯で 2 要因分散分析。

\section{III. 結果}

Frequent 条件と Rare 条件での $0 x y-H b$ を比較するた
め, 各計測箇所における $15 \mathrm{sec} こ ゙ と の$ 平均 $0 \mathrm{xy}-\mathrm{Hb}$ 量を 算出し，条件（2）×計測简所（8）の2 要因分散分析 を実施した（Fig. 1)。その結果，課題開始後 45-75sec の時間帯では $1 \%$ 水準で，また 15-45sec ならびに 75-90sec の時間帯では 5\%水準で条件間の主効果が求

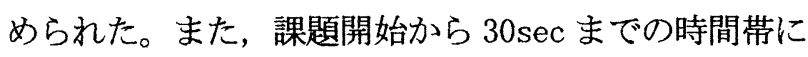
ついては，1\%水準で部位間の主効果が認められた。 IV. 考察

本研究では, 標的刺激の呈示確率が異なる CPT 課題 下での, 前頭前野の機能状態について NIRS データにも とづいてから検討した。その結果, 課題開始後 $15 \mathrm{sec}-90 \mathrm{sec}$ の時間帯の平均 $0 x y-H b$ 量に条件間で有意 差が認められた。このことは, Frequent 条件と Rare 条件では課題遂行に必要な認知処理が異なり, Frequent 条件ではその認知処理が早い段階から行わ れていることを示唆している。しかし, 課題開始後 $90 \mathrm{sec}$ 以降の時間帯では条件間に有意差がみられなか ったことから，課題が進むにつれて Rare 条件でも Frequent 条件と共通した認知処理が進行しているも のと考えられる。

このようにCPT の条件間で必要とされる認知処理が 課題開始後の早い段階で異なることは, Frequent 条件 と Rare 条件の課題方略の違いによるものと考えられ る。先行研究では, 標的刺激の呈示確率が高い条件で は非標的刺激に対する反応制御が求められることが指 摘されている (Bekker et al. , 2004 ; Silverstein et a1. ，2004）。このことから，本研究の Frequent 条件 で CPT 課題中を通して認められた前頭前野の活動は, 非標的刺激への反応制御が関係していると推察された。

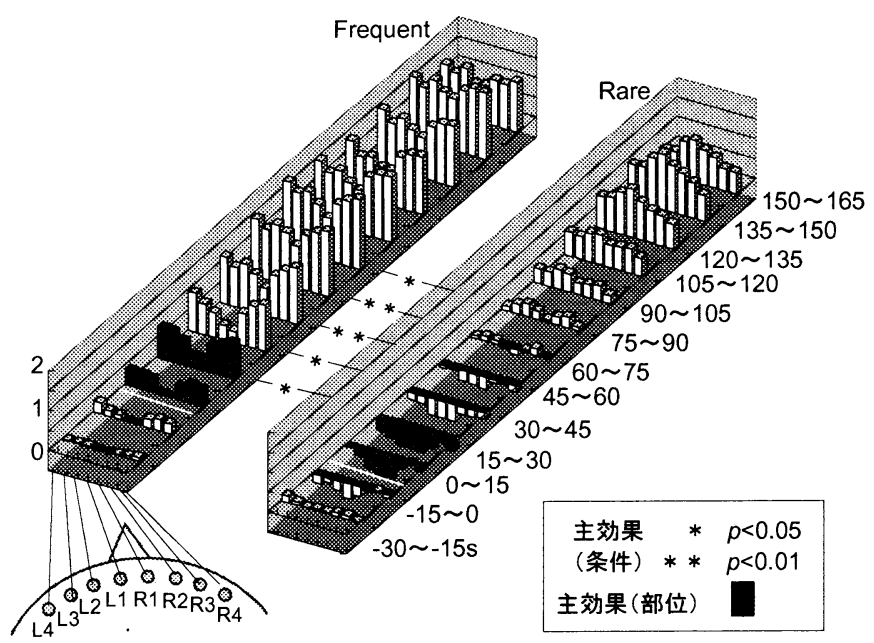

Fig.1 15secごとのCPT課題におけるOxy-Hbの推移 


\section{NIRS 実験における安静期画像呈示の効果}

○平石博敏 ${ }^{1,2}$ 脇田真清 ${ }^{1,2}$

\section{( ${ }^{1}$ 京都大学霊長類研究所) ( ${ }^{2}$ 日本科学技術振興機構)}

「はじめに」

- 課題に随伴する脳活動は, 課題間間隔(ITI) 中の活動と の対比として表されるため, ITI 中の活動を安定させるこ とで，信頼性の高い課題に関連した脳活動を記録するこ とができる。そこで，課題に非関連な画像を呈示し，ITI 中に認知的負荷を積極的に操作することによって, 課題 関連の脳活動が安定的に記録できると予想できる。

「方法」

被験者 : 20 歳代の健常成人 8 名（男性 4 名・女性 4 名） 手続き：(図 1)

試行間間隔に呈示される画像が異なる 2 条件を行った。 各条件とも 4 試行ずつ行ったが, 条件の順序は被験者ご とにカウンターバランスさせた。

課題 : モニター上に 3 桁と 1 桁の 1 対の数字を 30 秒間呈 示した。1 試行中に呈示される数字は同一であった。 3 桁マイナス 1 析の数の引き算を連続して行わせ, 計算結 果を口頭で報告させた。

ITI :ブランク条件 一様な暗画面が 30 秒間呈示される。 画像呈示条件 画面全体に花の写真が 30 秒間呈示される。
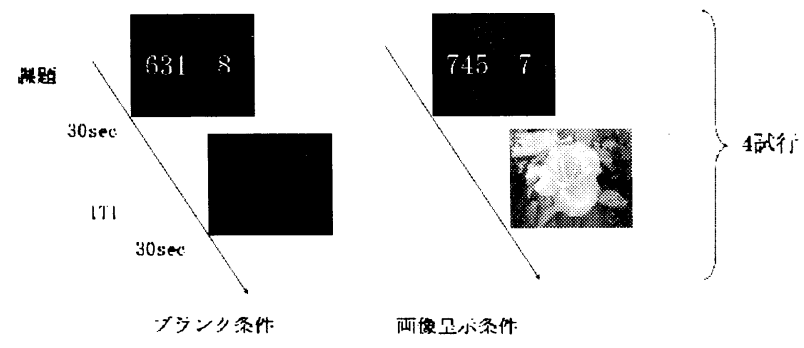

図 1 手続き

測定部位： $3 \times 5$ プローブ (22 チャンネル)を左右対称か つ国際 10-20 法のFP1, FP2 が最下列にくるように配置し た。計算結果を言語報告させたことから，ブロカ領域近 傍の $8,9,13,17,18$ の 5 チャンネルを分析対象とした。時 間分解能は $10 \mathrm{~Hz}$ で計測し，刺激前 5 秒間，ITI 終了前 5 秒間の平均值を通る一次関数で試行ごとに補正したもの を 5 チャンネル・4 試行分で平均した時系列データを以下 の分析に用いた。

分析 : 1 試行あたり平均 10 回以上回答した被験者 6 名の データについて分析を行った。計算結果を言語報告させ たことから, 左半球の $8,9 ， 13 ， 17 １ 8$ の 5 チャンネル を分析対象とした。時系列データにおける 5 秒間 $(50$
ポイント）を1ウィンドウとし, 課題前の 5 秒間（ベー スライン) での平均活動強度と, 1 ポイントずつ移動させ たウィンドウの平均活動強度を比較した（t-test）。有意 水淮は $\mathrm{p}<0.01$ とした。この比較により, 以下の 2 指標を 条件間で比較した。 ベースラインと比較し, 試行開始後に連続して 1 秒以上 有意差が現れたウィンドウの第一ポイントの時点を賦活 潜時, ベースラインと比較し, 試行終了後に連続して 1 秒以上有意差が消えたウィンドウの第一ポイントの時点 を賦活終了潜時として，これらの指標を条件間で比較し (Wilcoxon signed-rank test)た。このとき，有意水準を $\mathrm{p}<0.05$ とした。

「結果と考察」

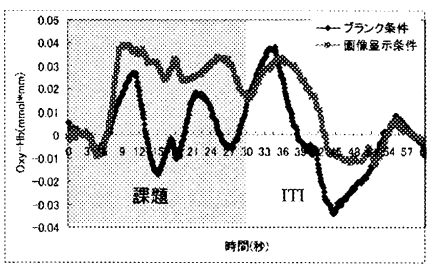

図 2 時采列データ

課題中, 画像呈示条件ではブランク条件より信号が安定 していた。

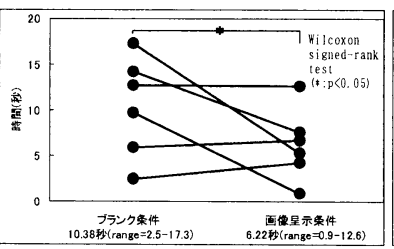

図 3 賦活反空潜時

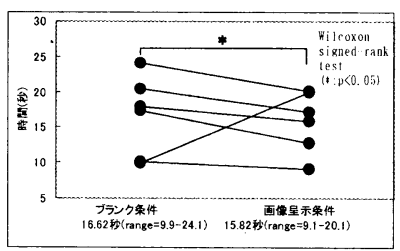

図4 賦活終了潜時
反応潜時はブランク条件で 10.38 秒 (range=2. 5-17.3), 画像呈示条件で 6.22 秒 (range=0.9-12.6)であり, 有意差 があった ( 10.05$)$ (図 3)。賦活終了潜時はブランク条件で 16. 62 秒 (range=9.9-19.1), 画像呈示条件で 10.82 秒 (range=4.1-15.1)であり, 有意差があった ( $\mathrm{p}<0.05)$ (図 4)。 ITI に視覚刺激を呈示すると, 試行中の賦活に課題関連性 が高まった。これは風景画像や注視点によって前頭前野 での血流减少(Shulman et al. (1997) J. Cogn. Neurosci. 9，648-663)が見られたことより，ITI における賦活が安 定して低く抑えられたためだと考えられる。これらのこ とから, ITI での積極的な認知操作によって安定かつ効率 的な脳活動を記録できる可能性が示唆された。

今後は, 課題・刺激の種類, 測定部位の違いによって ITI の画像呈示効果の有効性に違いがあるかを検討する必要 がある。 
脳酸素交換機能マッピング (COE)の認知計測への応用 -CBF の限界と COE の有効性一

○吉野加容子 (慶応義塾大学後期博士課程政策メディア研究科) 加藤 俊徳(株式会社脳の学校 $\left.{ }^{m}\right)$

\section{1. はじめに}

ヒトの認知機能計測において信頼性に足る指標は 何だろうか? 脳血流 (CBF)の強い影響を検出する PET や fMRI では, 血液の運搬を行うだけで神経活動を直接 反映しない静脈信号によって機能誤診が引き起こされ ることが指摘されている。

我々は，毛細血管内での外生じる酸素交換機能（図 1) に着目した。脳酸素交換機能マッピング (COE) は, 毛細血管内で生じる酸素消費反応 (=FORCE 効果 : $\mathrm{Oxy}-\mathrm{Hb} \rightarrow$ Deoxy-Hb $+\mathrm{O}_{2}$ ) と酸素供給反応 (素通り反応 : $\mathrm{Oxy}-\mathrm{Hb} \rightarrow \mathrm{Oxy}-\mathrm{Hb}$ )を区別できる唯一の方法である。こ の方法を用いて毛細血管内の酸素交換機能を検出し, 酸素消費反応と酸素の素通り反応とを区別することに より，語彙の認知などのわずかな信号を捉えることを 試みた。具体的には，単語を受動的に聴取させ応答を 求めずとも, 単語の意味を知っているかどうかに応じ て酸素交換機能が変化するかを調べた。

\section{2. 方法}

対象：健常成人 13 名（平均年齢 23.5 歳, 男性 3 名/ 女性 10 名, 全対象者とも右利き）とした。測定と発表 に際して文書で了承を得た。記録：Hb 測定は近赤外線 分光測定法を利用した装置（ETG-100）を使用した。 $\mathrm{Hb}$ 取得のサンプリング間隔は $100 \mathrm{~ms}$ であった。

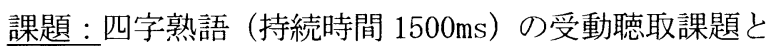
した(21 単語を 1 回ずつ聴取/Rest20sec)。また統制群 として純音 $(1000 \mathrm{~Hz} / 1500 \mathrm{~ms})$ の聴取も行った。測定後に, 聴取させた単語の意味を知っているかどうかを報告さ せ，それに応じて「理解語」「非理解語」に分離して解 析を行った。測定部位は, 高密度プローブを採用し(加 藤, 2004), 左右半球の BA45〜BA22 後部までとした。 解析：(1)空間解析：理解語と非理解語で反応が異なる 部位を求めるため, 聴取時間 $1500 \mathrm{~ms}$ における 0-D 值の 積分值を算出し, T 検定を行った。(2)時間解析 : 理解 語と非理解語で反応が異なる時間を求めるため，0-D 值とTotal-Hbについて各時点で語群間T検定を行った。

\section{3. 結果 (1)理解語と非理解語間の空間的差異}

単語聴取中における語群間の差異は, 右半球と左半 球前部にはなく, 左側頭葉後部で認められた $(\mathrm{p}<0.05)$ 。 この部位では, 理解語で酸素消費反応が生じ, 非理解 語で素通り反応を示した。一方, 聴覚野では, 両群で 酸素消費反応が観察された。

\section{(2)理解語と非理解語間の時間的差異}

左半球後部における理解語と非理解語の差異は, 聴 取後に $0 \mathrm{xy}-\mathrm{Hb}$ が増加する脳血流 (CBF) の時間帯には無 く, 単語聴取に同期して有意差が検出された $(\mathrm{p}<0.05)$ 。

\section{(3)語音と非語音聴取における酸素交換機能の差異}

語音に対寸る意味理解の有無は左半球後部で判別 可能であったが，語音か非語音かの判別は対称部位の 右半球後部で可能であった（p<0.05）（図 1)。ラテラ リティは脳血流量の差でなく, 酸素消費反応と素通り 反応の差異であった。

\section{4. 考察}

聴取単語の意味理解の有無に応じて，酸素交換機能 が変化することが明らかとなった。従来，脳機能の指 標とされてきた遅れて生じる脳血流 (CBF) では, わずか な認知機能が捉えられず，脳機能のパラメータとして 精度がないことが示された。認知機能計測には，酸素 交換機能 (COE) の適用が有効である。理解語の酸素交換 機能は, 左側頭葉後部での聴取時間中の酸素消費反応 であった。一方，非理解語では素通り反応が生じた。

本研究で行ったように，単語を 1 度聞かせるだけの 精度であれば，教育やリハビリなどの臨床的な応用が 可能であると考えられる。今後, 酸素消費反忘に着目 し，様々な課題と酸素交換機能との対応を研究する。

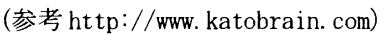

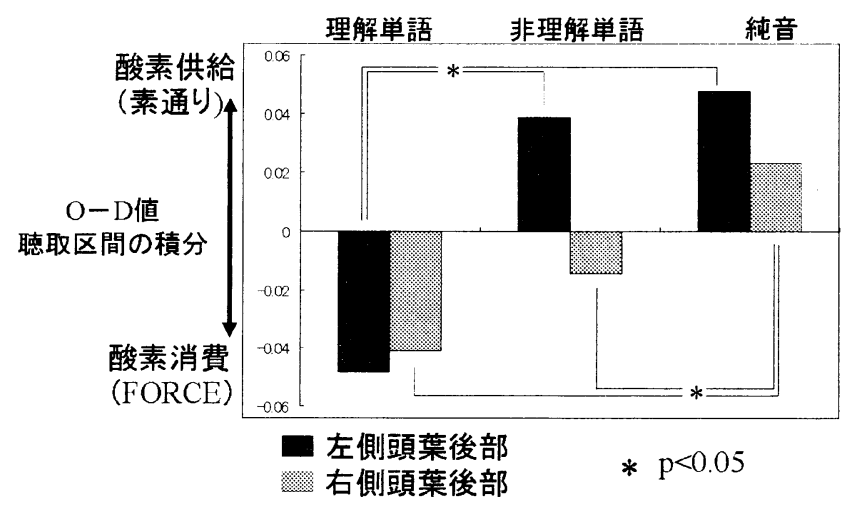

Figure 1．聴取中 $(1500 \mathrm{~ms})$ における酸素交換機能の差異 


\section{高龄者の $\alpha$ 帯域成分に関する検討} ースペクトル構造を中心にー

$\bigcirc$ 水上 喜美子・藤澤 清 (仁愛大学人間学部) 寺田 信一 (高知大学教育学部)

堅田 明義 (中部学院大学人間福祉学部)

\section{1.はじめに}

基礎活動の徐波化（ $\theta$ 帯域周波数の出現量の増加およ び $\alpha$ 帯域周波数の減少）は，高齢者脳波の最も重要な特 徵の一つであると言われている。しかし, 基礎律動の周 波数は, 加㱓にともない漸次減少していくのか（周波数 の連続的変化)， $\theta$ 帯域成分， $\alpha$ 帯域成分がそれぞれ独 立に変化しているのか（周波数の非連続的変化）につい て明確にされていない。そこで本研究では，加齢による 基礎活動の徐波化について検討するために， $\alpha$ 帯域成分 の周波数とそのスペクトル構造との関係を明らかにする ことを目的とした。そのために, 脳波の変動性に着目し, 脳波の変動性について $\alpha$ 帯域のパワの変動係数 $(\mathrm{CV}$ : coefficient of variation）によりその定量化を試みた。ま た, 平均パワスペクトルの時間経過（スペクトルアレ イ）と平均パワスペクトルからの検討も行った。

2. 方 法

1）対象者：対象は，脳血管障害などの既往歴が認めら れない高齢者 50 名 (61 91 歳, 平均 75.98 7.13 歳) であった。

2）調查場所：調査は $O$ 市の老人福祉センターで行った。

3）記録指標: 脳波は, 両耳架を基準部位として, 国際 10-20 法に基づく 10 部位 $\left(\mathrm{F}_{3}, \mathrm{~F}_{4}, \mathrm{C}_{3}, \mathrm{C}_{4}, \mathrm{P}_{3}, \mathrm{P}_{4}, \mathrm{~T}_{5}, \mathrm{~T}_{6}, \mathrm{O}_{1}\right.$,

$\left.\mathrm{O}_{2}\right)$ から測定した。座位，安静閉眼の状態で記録をした. 脳波の記録には，多用途テレメータサイナアウト MT11

（NEC 製）を用いた。信号はVital Recorder (KISSEI COMTEC 社製) によりサンプリング頻度を $500 \mathrm{~Hz}$ として A/D 変換し, ノート型パソコンのディス クに収録した。

4) 結果の処理法: 脳波の分析は, 周波数の分解能を $0.25 \mathrm{~Hz}, 2048$ 点 (約 4 秒)を 1 エポックとし, ハニン グ空による平滑化処理を行った。次に，FFT解析をおこ なうオートパワスペクトルを求め, 15 エポックのオー トパワスペクトルから平均パワスペクトルを算出した。 さらに, $\alpha$ 帯域のパワの変動性を定量化するために, 変 動係数を求めた. 変動係数を $\mathrm{CV}=\sigma / \mu$ の公式により算 出した。ここで, パワの変動係数はピーク周波数 $(\mathrm{n})$
及び隣り合う周波数 $(\mathrm{n}+1, \mathrm{n}+2, \mathrm{n}-1, \mathrm{n}-2)$ の平均值とし た。その後, 分析区間を 512 ポイントとし重複で約 256 ポイントずらしとした約 15 秒間のスペクトルアレイを 求めた。

3. 結 果

1）高齢者の安静時脳波の特徴 : 後頭部 $\left(\mathrm{O}_{1}\right)$ の脳波に ついて, 暦年齢と優勢周波数成分との関係を検討したと ころ，関連性は認められなかった $(r=-.10$, n.s. $)$ 。

2） $\alpha$ 帯域のパワの変動係数（以下 CV）について:暦 年齢と CV との相関関係を検討したが，関連性は認めら れなかった（ $r=-.19$, n.s. $)$ 。

ここで, 安静閉眼時における脳波の優勢周波数の変動 性に注目し，徐波化が認められた高齢者群（12 名：8.0 $\sim 8.75 \mathrm{~Hz}$ ) と認められない高歯者群（13 名 : 10.25〜 $13.0 \mathrm{~Hz})$ について比較した。この結果, 徐波化が認めら れる高齢者数と徐波化が認められない高齢者の変動係数 に相違は認められなかった $(t \quad(23)=0.96$, n.s. $)$ 。

3 ) 平均パワスペクトルの時間経過（スペクトルアレ 1）と平均パワスペクトルについて: 徐波化が認められ た高齢者と認められない高齡者のスペクトルアレイと平 均パワスペクトルについて検討したところ, その出現様 式に大きな相違は認められなかった。平均パワスペクト ルにおいて, 単峯性のスペクトル構造を示寸例もみられ たが， $\theta$ と $\alpha$ の両成分が同時に出現する 2 峯性のスペク トル構造を示す例も認められた。ここで，高齢者と若年 者のスペクトル構造について比較すると, 平均パワスペ クトルにおいて差異は認められないが，スペクトルアレ イでは出現様式は異なっていた。高齿者に比べ若年者で は，持続した単峯性のスペクトルアレイがみられた。

4. まとめ

徐波化が認められる高齢者と認められない高齢者の CV に相違が認められなかったことから，加歯にともな い脳波が複数の周波数成分から構成されるようになるこ とが推察された．さらに，平均パワスペクトルの時間経 過と平均パワスペクトルについて検討した結果, 高齿者 では, 複数の周波数成分への分峰化やピーク周波数の摇 らぎが示唆された。 $\alpha$ 帯域成分には，広汎性成分と局所 性成分という複数の成分の存在が認められ，スペクトル 構造は各成分から構成されていることが考えられる。

以上のことより，加齢により $\alpha$ 律動の形成に関与する 複数のネットワーク間の結合が弱まることに由来するこ とが推定される。 
脳波コヒーレンスによる情報の符号化に関わる脳内処 理過程の検討

\author{
○田中 志帆 \\ 岡崎 慎治 \\ 前川 久男 (筑波大学人間総合科学研究科)
}

知能とは何か, またどのように評価するのかについ て科学的なアプローチが試みられてきた。 K-ABC (Kaufman Assessment Battery for Children: 1983) やDN-CAS (Das-Nagrieli Cognitive Assessment System：Naglieri \& Das, 1997)等の認知検査は, 臨床観 察から提唱された Luria（1973）の符号化様式として の同時・継次統合の概念を導入している。

同時・継次処理という符号化様式の存在について, 因子分析的妥当性は示されている。一方高次脳機能は 複数の脳皮質部位間の協働により成立している (Luria, 1973）と考えられている。このことから脳の 2 部位間の電気活動の相関から脳機能を概観できる脳 波コヒーレンス（coh）による分析が有用であろう。

本研究の目的は, 同時一継次処理課題を受動・能動 条件で遂行中の coh パターンの検証から 2 つ符号化 様式の差を検討することである。さらにこの前提とし て知能の処理様式仮説に対し生理学的な検討を行う。

<方法 > 対象者 事前に説明を受け, 実験参加に同意 した健常成人男性 8 名, 女性 6 名, 計 14 名 (平均 23.9 歳). 手続き 課題は DN-CAS の同時・継次処理の下位 検查を脳波测定に適するよう改変し, 受動的知覚条 件・能動的処理条件の 2 条件で呈示した。Figure Memory (FM) 受動条件:画面上に呈示される単純/複雑な 幾何学図形を見る。FM 能動条件 : 呈示される単純図形 を記憶後,より複雑な図形の中から記憶した単純図形 を探す。Word Series (WS) 受動条件 : 音声で呈示される 単語系列を聞く。WS 能動条件 : 音声で呈示される単語 系列を記憶し再生する。脳波記録と処理 脳波は EOG とともに 30 部位から両耳梁を基準とし, サンプリング 周波数 $500 \mathrm{~Hz}$ で記録した。0.05〜 $50 \mathrm{~Hz}$ のバンドパスフ イルタ処理後, $\pm 100 \mu \mathrm{V}$ 以上のアーチファクト混入試 行は分析対象から除外した。刺激呈示前 $100 \mathrm{~ms}$ から刺 激呈示後 $1948 \mathrm{~ms}$ の 2.048 秒間を分析対象区間とし高速 フーリエ変換後, $\theta$ 帯域 3.9-6.8 Hz, Lower $\alpha$ 帯域 6. 8-9.8Hz の coh 值を算出した。coh 值 confidence limits (Otones \& Enochson, 1972) より coh 值の Fisher
Z 值が 0.355 より大きいとき, 有意に大きいとした。 <結果と考察 $>$ 同時・継次処理課題を受動・能動条件で 呈示し,coh の変化のパターンを検討した。運動反応を伴 わない記憶条件において FM では受動条件と記憶条件 間の coh の変化に有意差がなかった一方でWS では coh が有意に低下するコネクションの存在が確かめられた (Fig.1)。このことから同時処理・継次処理という符号化様 式の差が coh に反映された可能性が示唆された。今後感 覚モダリティや課題の難易度の要因の検討と複数の同時 課題・継次課題を用いての検討が必要である。また,coh 值の変動が課題負荷の影響によるものであるかを検討す るため次の検討を行った。

FM 受動・能動条件において 2 種類の刺激呈示中の coh を比較した。受動条件においては単純・複雑という 2 種類の刺激間で Lower $\alpha \cdot \theta$ 帯域における coh 值に有意 差が生じたコネクションはなかったが,能動条件において は刺激間で coh 值に有意差が生じたコネクションがあった (Fig.2)。このことから coh 值における変動は刺激の複雑 性といった要因ではなく,課題に関連する処理が要求され た際の処理 負荷の違い がより影響 する可能性 が示唆され た。今後は 他の同時課 題, 運動反 応を伴わな い課題を用 いての同様 の検討が必
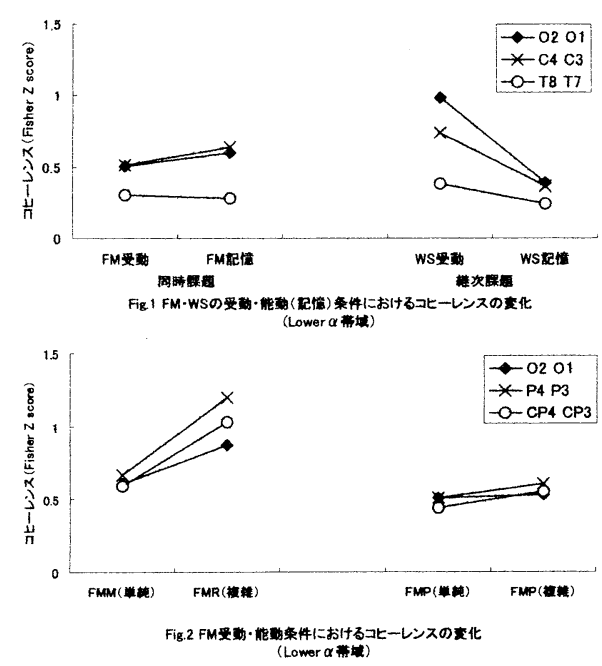
要である。

<参考文献>

Kaufman, A. S. \& Kaufman, N. L. (1983) Kaufman Assessment Battery for Children ( $\mathrm{K}-\mathrm{ABC})$ Administration and scoring manua1.

Luria, A. R. (1973) The working brain: An introduction to Neuropsychology.

Naglieri, J. A. \& Das, J. P. (1997) Cognitive Assessment System.

Otones, R. K. \& Enochson, L. (1972) Digital time series analysis. 
脳波基礎律動 6-10Hz 带域パワの事象関連性同期化(3)

○角 愛鹿 (高知大学大学院教育学研究科)

寺田 信一 (高知大学教育学部)

\section{1. 研究の目的}

人間の視覚的処理を 2 段階に分けると，低次な処理 では絵を分析・統合する視知覚の体制化が行われ, 高次 な処理では多くの人において右半球で形態認知が，左 半球で言語化が行われる。

本研究では，健常成人と発達障害児を対象に，主観 的輪郭を生じる形態図版と具体的事物の形態図版と具 体一抽象の形態図版を呈示して,脳波上の局所的覚醒過 程の違いについて検討し, 発達障害児の視知覚の体制 化と形態認知，言語化について考察する。

\section{2. 方法}

1) 対象者: 発達障害児 11 例 ( $\mathrm{CA}: 5$ 歳 4 力月-14 歳 2 力月, $\mathrm{DA}: 4$ 歳 3 力月 -16 歳 7 力月)。健常成人 20 例(男 女 10 名ずつ, 年齢 19 歳 -22 歳)。

2)課題 : (1)picture 課題では, 名称のみを想起させる 形態として，「犬」の絵を慣化刺激，「魚」の絵を脱慣 化刺激とした。(2)subjective contour 課題では，主観 的輪郭を生じさせる形態として，パックマンの絵を慣 化刺激，三角形が出現する絵を脱慣化刺激とした。(3) pictogram 課題では，言語化を想起させる具体的 - 抽 象的な形態として，「山」の絵を慣化刺激,「山」の漢 字に近似した絵を脱慣化刺激とした。

3) 手続き：慣化刺激を 3 回呈示したのち, 脱慣化刺激 を 1 回呈示し,その後, 再び慣化刺激を 1 回呈示した。 課題(1)(2)(3)をランダムに計 60 セット呈示した。刺激呈 示時間は $300 \mathrm{~ms}$ とした。刺激間間隔はオフセットで $700 \mathrm{~ms}$ とした。課題間間隔は約 3 秒とし，実験者がボ タン押しで呈示した。呈示画面は被験者から前方 $65 \mathrm{~cm}$ に設置した。

4)脳波：国際 10-20 法に準じ Fp1, Fp2, F3，F4，C3, C4, P3, P4, 01, 02, F7, F8, T5, T6 の 14 部位から右耳架を 基準電極として導出した。また，眼球運動と心電図の モニターのために，右眼窩上下より垂直眼電図を，左 右鎖骨中点より心電図をそれぞれ導出した。脳波記録 は $200 \mathrm{~Hz}$ で $\mathrm{A} / \mathrm{D}$ 変換した後パーソナルコンピューター のハードディスクに記録した。

5) 分析方法 : 脳波データに対し，14ch のうち刺激前 $0.28 \mathrm{~s}$ から刺激後 $1 \mathrm{~s}$ の区間で $150 \mu \mathrm{V}$ 以上の電位を示 した場合，その epoch は分析対象から外した。 rest 脳 波については，5.12s×4epoch について $8 \mathrm{~Hz} \pm 2 \mathrm{~Hz}$ で envelope を算出した。envelope に基づきパワーの平均 と SD を算出した。 task 時については, 刺激前 $0.28 \mathrm{~s}$ から刺激後 $1 \mathrm{~s}$ の区間について $8 \mathrm{~Hz} \pm 2 \mathrm{~Hz}$ で envelope を算出した。task 時の envelope 波形に対して, rest のパワーの平均と SD に基づいて正規化した。得られた envelope 波形は刺激の立ち上がり時間でそろえ, 加算 平均した。各加算回数は, 健常成人では各刺激 7 回-15 回，対象児では各刺激 9 回-15 回であった。その後, 刺激前 $0.28 \mathrm{~s}$ 区間と刺激後の各時点 $\pm 0.14 \mathrm{~s}$ との paired- $\mathrm{t}$ 值を算出した。 $\mathrm{p}=0.01$ に相当する $\mathrm{t}$ 值を超 えて peak を形成する点を分析の対象とした。

3. 結果

subjective contour 課題(視知覚の体制化をみる課 題)についてのみ, 脱慣化がほとんどみられなかった発 達障害児は 3 名 (高機能自閉症，自閉症，ADHD)であっ た。低次な視覚的処理である, 視知覚の体制化に関わ る脳活動が明瞭でなかったと推測された。

subjective contour 課題や pictogram 課題において, 左半球に脱慣化が明瞭にみられ，右半球では脱慣化が わずかであった発達障害児は 3 名 (高機能自閉症, ADHD, 乳児重症ミオクロニーてんかん)であった。subjective contour 課題や pictogram 課題での形態認知に弱さが 認められると推測された。

pictogram 課題 (言語化を想起させる課題)について, 右半球側頭葉に脱慣化がみられ，左半球頭頂部に脱慣 化がみられなかった健常成人と同様の反応を示した発 達障害児は 2 名 (アスペルガー症候群, 自閉症)であっ た。健常成人においては，形態としては異なるものと して認知し，言語としては同じものとして認知する効 率化がみられたのではないかと推測された。発達障害 児の 2 名においては，発達年齢から考え，健常成人と 同様の効率化を行った可能性あるいは言語化がなされ なかった可能性が推測された。

各課題において，第 1 成分が健常成人に比べ潜時が 早く, ピーク $\mathrm{z}$ 值が 2 を超える発達障害児は 3 名 (アス ペルガー症候群, 自閉症, 聴覚障害)であった。この過 剩反応は過敏性によると推測された。

4.まとめ

発達障害児を対象に，事象関連性変動を指標として 大脳の局所的覚醒過程に着目したところ, 視知覚の体 制化の弱さ，過敏性による事例を示唆した。 


\section{EEG を指標とした聴覚情報処理における 時間一周波数的検討}

○越 勢治 ${ }^{1}$ 八木 昭宏 ${ }^{2}$

(1 関西学院大学大学院文学研究科)

(2 関西学院大学文学部)

【序論】聴覚情報処理におけるバッファとして temporal window of integration (TWI) が仮 定されている。TWI を研究する指標として MMN (mismatch negativity) とSSR (steady-state response) がある。Ross \& Pantev (2002) は 定常的に呈示される刺激（AM 変調 $40 \mathrm{~Hz}$ ) が変 化した後, SSR は一度消失し, 復帰に $200 \mathrm{~ms}$ 必要とすることを報告した。彼らは，この潜時 が TWI のdurationであると結論付けた。一方, 潜時 $200 \mathrm{~ms}$ は変化検出に対して自動的に惹起 する, MMN 成分のピーク潜時と一致する。そこ で本研究は SSR の振る舞いと, MMN の振る舞い を比較し, TWI を検討することを目的とした。

【方法】参加者は健康な聴力を有する大学生, 及び大学院生 8 名。平均年齢 22.5 歳 (21-26) であった。参加者はインフォームドコンセント を通じ，実験参加に同意した。

実験に用いた刺激は $500 \mathrm{~Hz}$ （duration12.5 $\mathrm{ms}$ ) の tone burst (rise \& fall $1.2 \mathrm{~ms}$ ) であ った。刺激は $40 / 1 \mathrm{~s}(40 \mathrm{~Hz}=\mathrm{S} 0 \mathrm{~A} 25 \mathrm{~ms})$ の 頻度で $80 \mathrm{dBSL}$ でヘッドホンにより呈示された。 刺激は $1000 \sim 3000 \mathrm{~ms}$ に一度, ランダムなタイ ミングで逸脱した。逸脱には周波数変化（450 $\mathrm{Hz}$ ：f Change）と刺激欠落（Gap）の 2 条件が あった。条件はブロック間で異なった。参加者 は実験中, 無音映画を鑑賞した（非注意状態）。

脳波は頭皮上 30 箇所より基準電極を鼻尖と して記録された（High-cut $100 \mathrm{~Hz}$, Low-cut $0.05 \mathrm{~Hz}$, sampling rate $500 \mathrm{~Hz})$ 。頭皮上電位 は条件別に加算平均され, 時間一周波数解析さ れた。統計的処理にはF 2 の電位が用いられた。

【結果】両条件とも刺激潜時 100-200 ms に F Z 最大振幅の MMN が観察された（Fig. 1)。ERP の 時間一周波数解析 (zero-phase shift の bad pass filter (32-48 Hz) による evoked event-related desynchronization) で得られ た SSR は, 両条件とも逸脱から潜時 $200 \mathrm{~ms} に$
かけて低下が見られた（Fig，2）。そこで逸脱

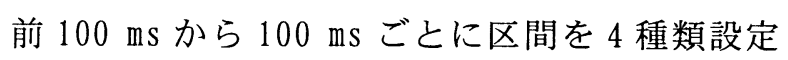
し，それぞれの区間で SSR とERP の平均電位を 算出した (Base, Post(1), Post(2), Post(3))。 SSR とERP の電位にそれぞれ条件（2）×潜時 （4）の ANOVA（Huynh-Feldt 法により修正）を 実施した。下位検定はBonferroni 法を適用し た。SSR の ANOVA の結果, 潜時の要因に主効果 が認められた $(F(3,21)=5.4, p<.01) 。$ 下位検定の結果 Base とPost(1)において有意差 が認められた。ERPの ANOVAの結果, 潜時の要 因に主効果が認められ $(F(1.8,12.3)=19.4$, $p<.01)$, 交互作用が認められた（F（1.8, $12.5)=12.1, p<.01)$ 。下位検定の結果, Base とPost(2), Base とPost(3)有意差が認められ た。また, 潜時ごとの単純主効果による条件間 での比較を行ったところ, Post(2)区間における Gap 条件の MMN が顕著であったことが示された。

【考察】以上の結果より, 定常状態の変化によ るSSR の減少はMMN に先行していることが明ら かとなった。しかしながら, SSR の減少は MMN 振幅の增大には直接的に影響しないことが明 らかとなった。SSR の復帰過程とMMN 潜時との 関連が示唆された。

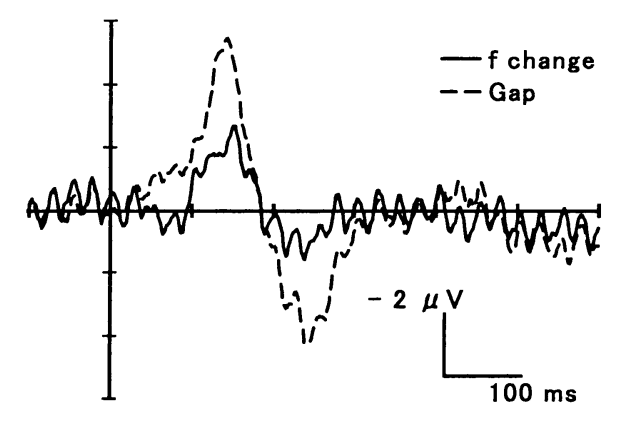

Figure 1. 条件別総加算平均波形 $(\mathrm{Fz})$ 。

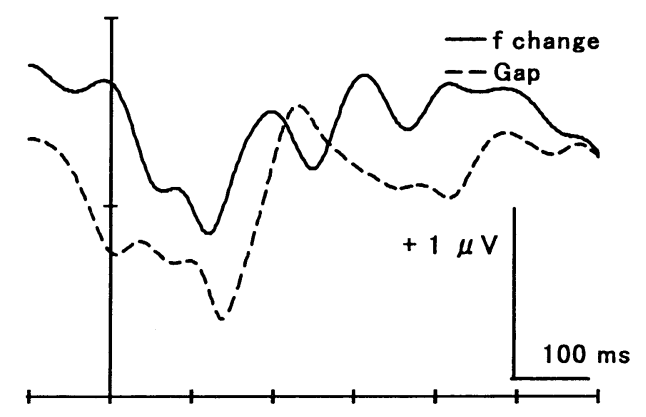

Figure 2. $40 \mathrm{~Hz}$ 帯域総加算平均波形 $(\mathrm{Fz})$ 。 


\section{時間一周波数解析と独立成分分析を用いた エラ一関連脳波成分の検討 \\ 松本 敦 \\ (名古屋大学環境学研究科・日本学術振興会)}

\section{【目 的】}

独立成分分析はデー夕の統計的な独立性に基づいて， 混合されたデー夕を空間的に固定した時間的に独立な成 分に分離する。また, 時間一周波数解析は各試行毎の周 波数パワ一，位相情報を抽出し，ERPでは解析不可能な 高周波成分や位相が試行毎に揃わない成分などの検討を 可能にする. 本研究ではこれらの手法とエリクソン型の フランカー課題を用いて近年注目を浴びているエラ一関 連成分の詳細な検討を試みる.

\section{【方 法】}

被験者 健康な右利きの大学生, 大学院生 13 名.

刺激 フランカ一刺激の一致条件 (SSSSS) と不一致条件 (SSHSS)の 2 つの刺激を用意した.

手続き 注視点 $1000 \mathrm{~ms}$ のあとにフランカーが $100 \mathrm{~ms}$ 呈示 された. 被験者は呈示された刺激の中央の文字に注目し, あらかじめ決められたボ夕ンを押すように教示された.

脳波は 32 極から鼻尖を基準として計測された. Lowpass filter は $120 \mathrm{~Hz}$ であり, 時定数は $10 \mathrm{~s}$ だった. サンプリ ング周波数は $250 \mathrm{~Hz}$ だった. 独立成分分析 (ICA) はEEGLAB を用いて全ての被験者に対して single-trial で行った. 全員のデータに ICA を行った後, 抽出された全ての成分 の頭皮上分布と spectral パワーに関して ICA clus tering を行い, これらの変数が似ている成分を分類した. これ ら分類された成分に対して時間-周波数解析を行った. 時 間一周波数解析は 5-cycle の Morlet の複素ウェーブレッ 卜を用いて連続ウェーブレット変換を行ってパワ一值と 位相情報を抽出した. 各試行のパワ一值の平均值を算出 するのと同時に各試行間での位相の同期の程度を調べる ためにInter Trial Coherency (ITC) を計算した.

\section{【結果・考察】}

反応をトリガーとした ERP の結果に関しては先行研究 と一致した結果が見られた. すなわち, 反応直後に頭頂 部を中心とした陽性成分が観察された。誤試行では正試 行と比べて前頭中心部で振幅がネガティブに振れ，この 成分がERN (Ne) であると考えられる. 正試行ではネガテ イブ方向への振幅の振れは観察されず, Correct Response Negativity（CRN）は観察されなかつた. このデー夕に対 して ICA を行い，すべての得られた独立成分に関してク ラスター分析を行なって 20 個のクラスターに分類した. 図 1 に示したクラスターは Ne に一致すると考えられる成 分である. 左上がこのクラスターのトポグラフィー右上 は ERP である. 中段は時間一周波数解析のパワー值の結
果を表わしている. 左側か誤試行で右側が正試行である. 下段は試行間での位相の一致の程度を表わすITCである. この結果から，前頭中心部の独立成分において反応直後 に陰性の成分が若起していることが見てとれる. 正試行 でも陰性の成分（CRN）は見てとれるが誤試行でその成分

(Ne）は大きい. 次に ITC に注目してみると, 反応後 0 -200ms 区間で 5-7Hz 帯域で正試行と比較して誤試行で ITC が大きい.このこととERP に対する時間一周波数解析 の結果から $\mathrm{Ne}$ に対応する成分は5-7Hz 帯域の活動である ことがわかる. 次にパワ一值に注目してみると, Ne の出 現に対応する時間帯 (0-100ms), 周波数帯 (5-7Hz) で誤 試行では大きなパワーの上昇がみられるのに対して正試 行ではパワーの上昇のピークは反応直前に起こっており, CRN 出現時間帯ではパワーの上昇が見られなかった.この ことから, CRN の生起には試行間の位相の同期だけ (Pure Phase Resetting) が関わっており, Ne の生起には位相の 同期と共にパワー (振幅) の上昇が起こっている (Phase reset ting and Power Enhancement）と考えられる. また, Ne を反映していると考えられる成分のほかに ICA によっ て反応に関わると考えられる 2 つ成分が抽出された. 一つは頭頂中心部優位の陽性成分 (Pe), もう一つは $\mathrm{Ne}$ よりも前頭部を中心とした頭皮上分布を持つ成分で, 正 試行に比べて誤試行で反応後 $200 \mathrm{~ms}$ ほどでより大きな陰 性の成分が見て取れた.これらの成分がお互いに関連し あい反応モ二タリングや行動修正などの処理が行われて いると考えられる。
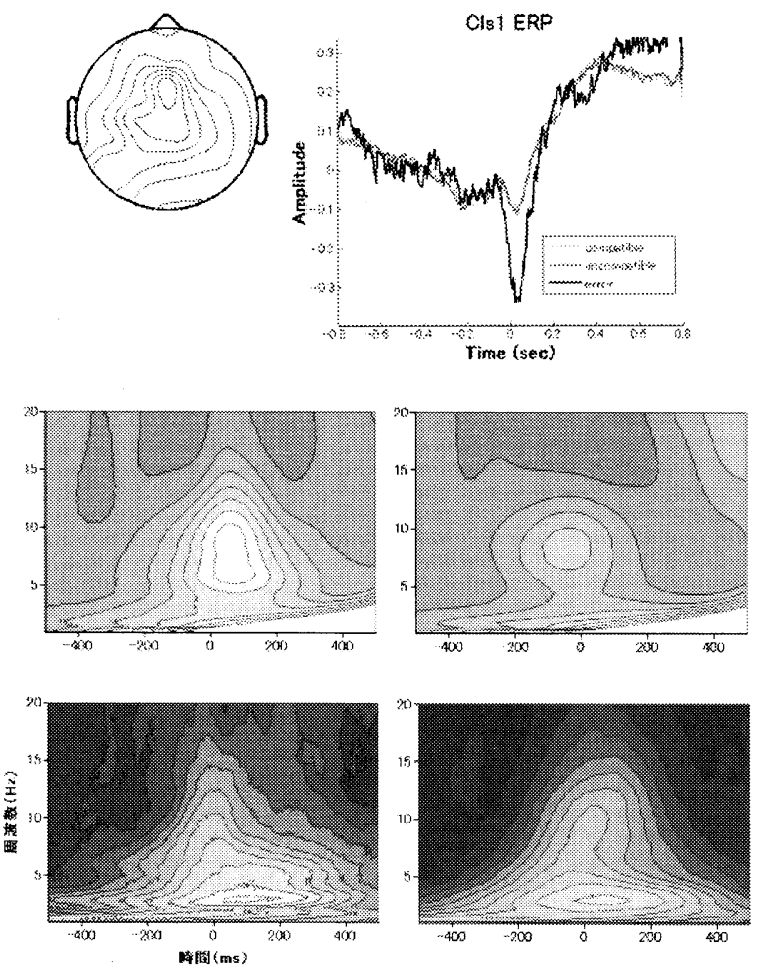

図 1 ICA Cluster1 のERP,TF プロット,ITC 
聴覚 oddball paradigmにおけるP300 の時系列変化に 関する検討

$\begin{array}{rll}\text { ○中尾 } & \text { 繁史 } & \text { (筑波大学人間総合科学研究科) } \\ \text { 宮地 } & \text { 弘一郎 } & \text { (金沢大学大学院社会環境科学研究科) } \\ \text { 藤澤 } & \text { 清 } & \text { (仁愛大学人間学部) }\end{array}$

\section{1. 問題と目的}

持続的に何かに注意を向ける必要がある場面でも， 覚醒水準や疲労などで注意は変動する。oddball paradigm 遂行時の 1 課題で ERP を求めると, その課題 での注意の変動は観察出来ない。注意の変動を詳しく 見るためには単一波形からの検討など，様々な方法が 考案されているが, テンプレートとして加算平均した ERP 波形を用いる事が多い。そこで，基本的な加算平 均法で， 1 課題をいくつかの区間に分けて加算平均寸 る事で変動を見る事ができないかを検討した。本研究 では, 聴覚 oddbal1 課題における低頻度刺激に対する 注意の変動を, 通常の加算方法の他に, いくつかに分 けて加算した P300 波形で検討する事を目的とした。 2. 方法

被験者: 大学生 12 人 (男性 6 名, 女性 6 名) を対象とし た。平均年齢は 21.3 歳 (年齢範囲 20-22) であった。 刺激 : $750 \mathrm{~Hz}$ と $1.5 \mathrm{kHz}, 1 \mathrm{kHz}$ と $2 \mathrm{kHz}$ の純音をそれぞ れ用いた。 4 音とも約 $65 \mathrm{~dB}$ で統一した。各セット 300 刺激を 50 刺激ずっ 6 ブロックに分け，低頻度刺激 (高 音刺激) と高頻度刺激の呈示頻度を各ブロックで $2: 8$ とした。刺激持続時間は $200 \mathrm{msec} と し ，$ 刺激間間隔は $1 \mathrm{sec}, 1.2 \mathrm{sec}, 1.4 \mathrm{sec}$ の 3 種類でランダムとした。

実験手続: 被験者は電極装着後, シールドルーム内の, スピーカ及び注視点から $2 \mathrm{~m}$ 離れた位置に配置したイ スに座り, 低頻度刺激にボタン押しを求める能動課題 もしくは被験者に何も求めない受動課題を行なった。 記録指標 : 脳電図及び眼電図を記録した. 脳電図は, $\mathrm{Fz}, \mathrm{Cz}, \mathrm{Pz}$ の 3 部位を両耳梁結合を基準として導出し た. 眼電図は右眼窩上下外側約 $1 \mathrm{~cm}$ に電極を装着した. 分析方法: 刺激呈示前 $100 \mathrm{~ms}$ から呈示後 $900 \mathrm{~ms}$ を切り 出しアーチファクトを含む波形を除き以下の方法で加 算した。(1)課題全体から波形を選択し加算, (2)課題を 前半 3 ブロックと後半 3 ブロックで 2 分割して加算し た。(3)ブロック 1-2，2-3，3-4，4-5，5-6 と 5 分割し 区間 2 - 5 を一部重複させ加算した。各課題ともに平均 加算回数は 16ー20 回の範囲であった。刺激呈示後

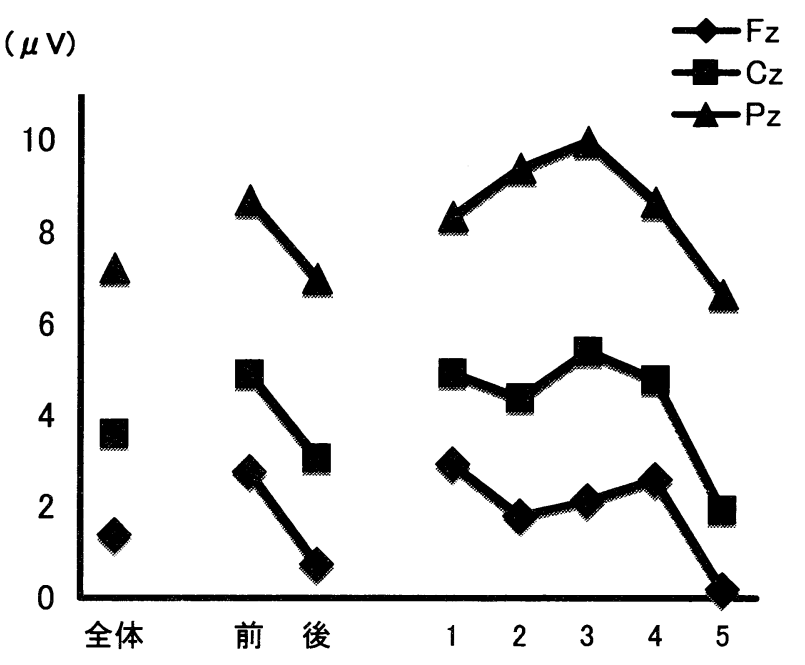

Figure 1. 能動課題の低頻度刺激呈示時の P300 振幅

250msー500ms 間の最大陽性ピークをP300 とした。 3 . 結果

能動課題での平均反応時間は $374 \mathrm{~ms}(\mathrm{SD}=79.1)$, 平均 誤答数 2 , 平均無反応数 0.6 であった。両課題とも低 頻度刺激に対する P300 波形に条件間で変化を認めた。 どちらの課題も低頻度刺激呈示時の P 300 振幅は, 2 分 割加算では前半から後半にかけて減少し, 重複 5 区間 加算では, 振幅が加算区間 1 - 5 にかけて減少する傾 向があった(Figure 1)。受動課題での低頻度刺激呈示 時の P300 潜時は一貫して減少していたが, 能動課題で は変動に一貫性は認められなかった。高頻度刺激呈示 時の加算波形は, 各課題ともに大きな变化は見られな かった。

4. 考察及びまとめ

重複 5 区間それぞれでの反応時間のばらつきが小さ い事から, 参加者の覚醒水準はある程度で一定してい たと考えられる。P300 振幅が, 前半から後半にかけて 減少したのは, 標的刺激に対して, 徐々に注意が払わ れなくなっている可能性を示している。P300 潜時は刺 激の処理時間を反映する事から, 受動課題の低頻度刺 激呈示時の P 300 潜時の減少は, 課題遂行中に低頻度刺 激の処理にかかる時間が減少していく事が要因として 考えられる。

本研究では聴覚oddball paradigm遂行時の注意の変 動を, 通常の加算方法の他に, 全体を 2 分割して加算 した P300 波形，一部重複させ 5 分割し加算した P 300 波形により観察する事ができた。 
障害児の休息-活動リズムと終夜睡眠時脳波 (1): 自閉症児の場合

\author{
○藤田 大慶 (鳥取大学大学院教育学研究科) \\ 広重 佳治（鳥取大学地域学部）
}

リズムある生活の形成は養護学校に通学し始めた障 害児において重要な学習目標であり, かつ保護者の願 いでもある。本研究は小学部在籍の自閉症児の生活リ ズムの実態解明を目的として,休息-活動りズムの記録 と在宅睡眠ポリグラフを実施した。

\section{方法}

被験者とインフォームドコンセント：養護学校小学部 に在学する自閉症児 7 歳 2 ケ月男子, 治療薬の常用な し)が本研究に参加した。本研究の説明を行い, 書面に よる同意を保護者より得た。記録： 3 軸方式のピアゾ 素子圧センサにより加速度圧を正確に計測する腕時計 型アクチグラフ (マイクロミニ RR 型) を非利き手に装 着し, $\mathrm{ZC}$ モードで 1 分毎の活動量を記録した(標本化 周波数 $16 \mathrm{~Hz}$, 分解能 $0.01 \mathrm{G} / \mathrm{Rad} / \mathrm{Sec})$ 。睡眠ポリグラフ は, 左右中心部脳波 (C3P3, C4P4), 水平眼球運動(左右 眼窩外側縁部)，オトガイ筋電位および心電図を標本 化周波数 $100 \mathrm{~Hz}$ で $\mathrm{AD}$ 変換し,ペーパレス脳波計で同時 記録した (BIOPAC 社)。手続き : アクチグラフは保護者 と教師の協力を得てセンサの着脱を行い, 通学日と休 日を含む連続 7 日間記録した。その期間中と期間後に 3 夜の在宅睡眠ポリグラフを実施した。睡眠中は母親 が添い寝をし，本児が就眠した後に脳波などの電極を 装着した。データ整理 : 第 3 夜の睡眠ポリグラフ記録 を 10 秒区画ごとに 4 つの状態 (STATE) に分類した：覚 醒，NREM 睡眠，REM 睡眠，運動時間。脳波パワスペク トルを最大エントロピー法により 10 秒区画毎に推定 した後, 帯域別にパワを算出した $(\delta: 1-4 \mathrm{~Hz}, \theta 1: 4-6 \mathrm{~Hz}$, $\theta 2: 6-8 \mathrm{~Hz}, \alpha 1: 8-10 \mathrm{~Hz}, \alpha 2: 10-13 \mathrm{~Hz}, \sigma: 13-15 \mathrm{~Hz}, \beta$ $15-20 \mathrm{~Hz})$ 。

\section{結果・考察}

本児の休息-活動リズムは約 24 時間周期を示し，昼 夜の交代に対応した (Fig. 1)。日中は起床時刻が午前 8 時過ぎとやや遅いが，その直後から活動量は急増し比 較的高い水準で維持された。就床時刻は午後 9 時-12 時の間であり，日によって必ずしも一定していなかっ た。夜間の活動量は全般に低いが，体動や寝返りがし ばしば記録された。午前 0 時前後に生じた 2 時間近い
覚醒（活動量の増加）は第 4 夜の嘔吐による。1 日の 累積活動量度には通学日に高く, 休日に低下寸る週間 動があった。

睡眠状態と帯域別パワの時間変動を Fig. 2 に示した。 本坚はNREM 睡眠と REM 睡眠を 1 セットとする睡眠周期 を平均 94.6 24.7 分で 4 回くり返した。 $\delta \cdot \theta$ 帯域 パワの出現は NREM 睡眠相に対応したが, 高いパワ值 (第 1 , 第 3 周期) と低いパワ值（第 2 , 第 4 周期）が 1 周おきに交互に現れた。これは睡眠のホメオスタシス 性調節の発達に関連した現象と考えられる。睡眠のホ メオスタシス性調節の脳波的特徵は成人では $\delta$ 帯域パ ワの消長（周期的減衰）とされるが (Borbély, 1984), 乳児では $\theta$ 帯域パワにその消長が現れ， $\delta$ 帯域につい ては本結果と同様に高いパワ值と低いパワ值の隔周交 替が生じるという(Jenni ら, 2002)。

$\alpha$ 活動には解離があった。一つは $\alpha 1$ 帯域の覚醒脳 波で(矢印), 生活年齢相応の周波数水準にあった。他 の一つは $\alpha 2$ 帯域で, NREM 睡眠相のみでパワが増加し, 睡眠紡鍾 $(\sigma)$ に相応すると考えられた。

本児の休息一活動リズムの休息相は生理的な睡眠周 期が存在するものの，ホメオスタシス性調節の発達の 未熟さが示唆された。

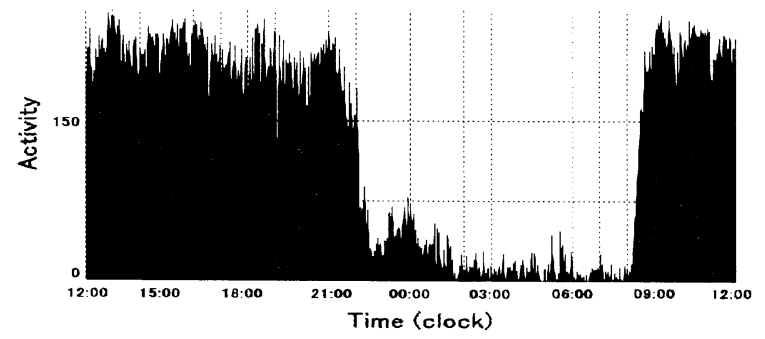

Fig.1 自閉症児の休息-活動リズム (1 週間の平均)

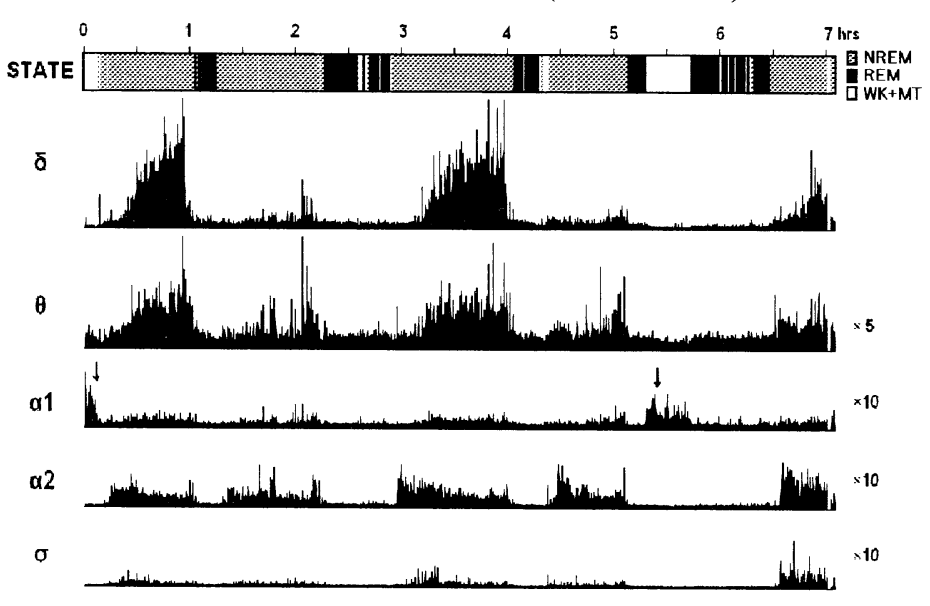

Fig.2 在宅睡眠における脳波帯域パワの時間変動 NREM:ノンレム睡眠，REM:レム睡眠，WK+MT:覚醒+運動時間 
障害児の休息-活動リズムと終夜睡眠時脳波 (2) : てんかん児の場合

○広重 佳治（鳥取大学地域学部）

藤田 大慶（鳥取大学大学院教育学研究科）

生活リズムの形成は養護学校に通学する障害児にお いて重要な学習目標であり, かつ保護者の願いでもあ る。本研究は高等部在籍のてんかん児の生活リズムの 実態解明を目的として休息一活動りズムの記録と終夜 睡眠ポリグラフを実施した。

\section{方法}

被験者とインフォームドコンセント : 養護学校高等部 に在学するてんかん児(15 歳 10 ケ月女子, 1 歳の頃に 発症し, 抗てんかん薬を朝夕服用)が本研究に参加した。 本研究の説明を行い，書面による同意を保護者より得 た。記録： 3 軸方式のピアゾ素子圧センサにより加速 度圧を正確に計測する腕時計型アクチグラフ(マイク ロミニ RR 型)を非利き手に装着し， $\mathrm{ZC}$ モードで 1 分毎 の活動量を計測した(標本化周波数 $16 \mathrm{~Hz}$, 分解能 $0.01 \mathrm{G} / \mathrm{Rad} / \mathrm{Sec})$ 。終夜睡眠は左右中心部脳波 $(\mathrm{C} 3, \mathrm{C} 4)$, 水平眼球運動 (左右眼窩外側縁部), オトガイ筋電位お よび心電図を標本化周波数 $100 \mathrm{~Hz}$ で $\mathrm{AD}$ 変換し,ペーパ レス脳波計で同時記録した(BIOPAC 社)。手続き:アク チグラフ記録は通学日と休日を含む連続 7 日間実施し た。その間の 2 夜, 本児は睡眠ラボの半防音の電気遮 蔽室内のベッドにて母親と一緒に睡眠をとった。消灯 後, 8 時間の睡眠ポリグラフ記録を開始した。OSA 睡眠 調査票に母親の援助を得て記入した。データ整理 : 第 2 夜の睡眠ポリグラフ記録を 10 秒区画毎に 5 つの状態 (STATE) に分類した：覚醒, NREM 睡眠, REM 睡眠, 運動 時間, 不明 (低筋緊張で速い眼球運動が不明瞭な状態, てんかん鋭波が区画の 50\%以上を占める状態)。脳波パ ワスペクトルを最大エントロピー法により 10 秒区画 毎に推定し, 7 帯域 $(\delta: 1-4 \mathrm{~Hz}, \theta: 4-8 \mathrm{~Hz}, \alpha: 8-13 \mathrm{~Hz}$, $\sigma: 13-15 \mathrm{~Hz}, \beta 15-20 \mathrm{~Hz})$ のパワを算出した。てんかん鋭 波 (三相性波形)を移動式直線回帰法により区画単位で 検出した (Hirosige, 1999)。

\section{結果・考察}

本児の休息活動リズムは約 24 時間周期を示し, 昼夜 の交代に対応した(Fig. 1)。活動量は午前 7 時台に目覚 めた直後から増え, 日中には約 2,3 時間の間隔で減少 する摇らぎが生じた。夜間は午後 11 時前後の 1 時間の
間に就床し，活動量は全般に低い值で経過した。睡眠 時てんかんに関連した異常行動は記録されなかった。 1 日の累積活動度が通学日に高く, 休日に低くなる週 間変動を認めた。

睡眠状態，てんかん鋭波並びに脳波帯域別パワの時 間変動を Fig. 2 に示した。睡眠前半 3 時間は REM 睡眠 が明瞭でなく、「不明」状態が多かった。NREM 睡眠相 の開始から次の開始までを睡眠周期として計測した結 果, 本児の睡眠は平均 $102.3 \pm 16.7$ 分の周期を 4 回く り返した。起床時の睡眠感(寝つき, 気がかり, 眠気) は比較的良好であった。

てんかん鋭波は平均出現数が 6.0 個/10 秒/周期で, NREM 睡眠相に頻発し, 覚醒と REM 睡眠相でほぼ沈黙し た。脳波 $\delta$ 帯域は第 1 睡眠周期でパワが影著に増加し た後, 睡眠周期の時間経過とともに漸减した。 $\delta$ 帯域 パワの周期的減衰過程は睡眠のホメオスタシス性調節 の脳波的特徽(Borbély, 1984) と考えられている。脳波 パワとてんかん鋭波の相関はいずれの周期でも $\delta$ 帯域 が最小となり $(=0.01-0.26), \theta$ 帯域と $\alpha$ 帯域では比較 的高い正相関を得た $(r=0.27-0.52)$ 。

本児の休息-活動リズムの休息相は, てんかん波の出 現を背景に, 睡眠ポリグラフで特徴づけられる睡眠周 期が存在し，ホメオスタシス性の睡眠調節を示唆する $\delta$ 活動が観察された。

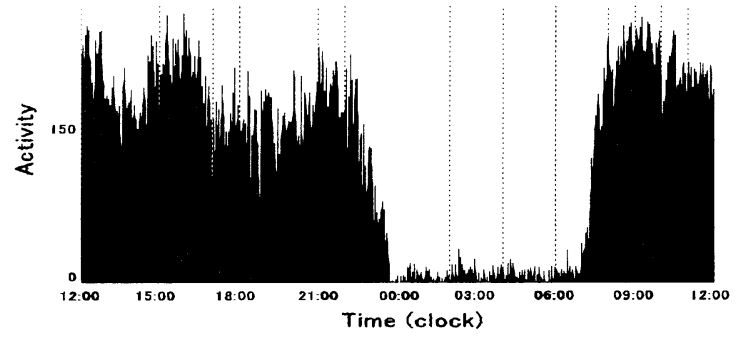

Fig.1. てんかん児の休息-活動リズム ( 1 週間の平均)

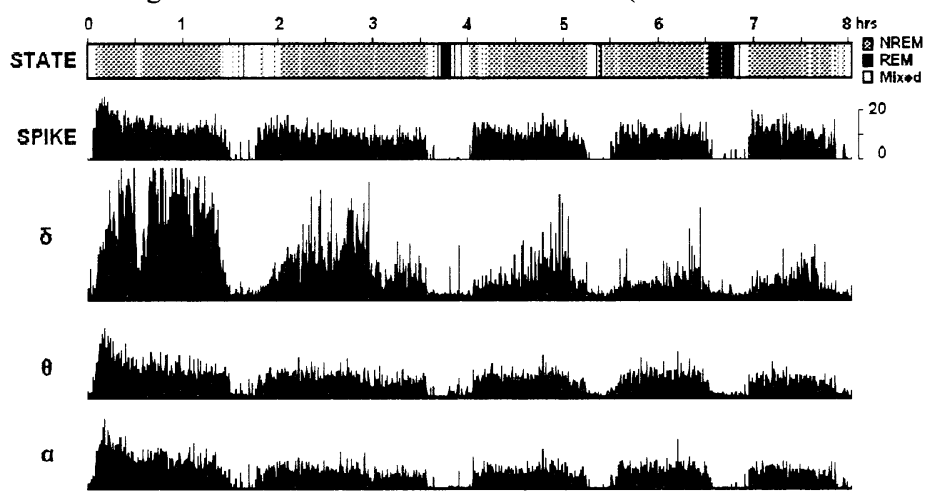

Fig.2 睡眠時の脳波帯域パワとてんかん鋭波の時間変動 NREM: ノンレム睡眠, REM:レム睡眠, Mixed:覚醒十運動時間十不明, SPIKE:てんかん鋭波の検出数 


\section{日中におけるリスク選択行動の時刻による変化}

○鈴木 博之（国立精神·神経センター）

田ヶ谷浩邦 (国立精神·神経センター)

内山 真 (日本大学医学部)

久我 隆一（日本大学文理学部）

\section{序論}

眠気を催しているときは冷静な判断力を失い、非合 理的な選択を行ってしまうことがある。選択行動は潜 在的・曊在的な意思決定過程によって行われる高次認 知機能であり、リスク選択という指標を用いて多くの 研究が行われている。リスク選択とはギャンブル、株 式投資など、どのような結果が得られるか分からない (不確実) 状況で、低リスク低配当よりも、高リスク 高配当の選択肢を選ぶことである。リスク選択行動は 前頭葉機能と関連することが近年の生理心理学的、神 経科学的研究により明らかになってきている。前頭葉 機能が日内変動し、眠気の影響を受けることが報告さ れているが(Cajochen et al., 2002)、リスク選択行動の 日内変動、眠気との関係を詳細に検討した研究はこれ まで行われていない。今回ギャンブル課題(Gehring \& Willoughby,2002)を用いて、日中におけるリスク選択 率の日内変動と、眠気との関係を検討した。

\section{方法}

16 名の健康な成人が実験に参加した。11,13,15,17 時にギャンブル課題を 96 試行ずつ行った。ギャンブ ル課題は、パソコン画面上に同時に呈示される[10]と [50]のどちらかを参加者に選択させた。選択した数が 当たりの時にはその数を獲得し、外れるとその数を損 失した。[50]の選択をリスク選択と定義し、リスク選 択率を時刻毎に算出した。先行研究により、前試行の 選択結果が獲得か損失かによって、リスク選択率が変 化することが示されているので (Gehring \& Willoughby,2002)、前試行の選択結果から大獲得後 (50 獲得)、小獲得後 $(10$ 獲得)、小損失後 $(10$ 損失)、大 損失後(50 損失)に分類し、それぞれのリスク選択率を 時刻毎に求めた。10、12、14、16、18 時には光点灯 に対するボタン押し反応により客観的眠気を測定する OSLER(Oxford Sleep Resistance test)を行い、課題前 にはVisual Analogue Scale による自覚的眠気の評定 を行い、それぞれリスク選択率との関係を検討した。 結果
前施行の選択結果と課題実施時刻を独立変数、リス ク選択率を従属変数とする 2 要因の繰り返しのある分 散分析を行った。リスク選択率は大損失後:61.1\%、小 損失後: $60.8 \%$ 、小獲得後: $59.6 \%$ 、大獲得後: $43.0 \%$ と、 前施行で大きく損失した後に最も高かった $(\mathrm{F}(3,45)=12.947, \mathrm{p}<.0001, \mathrm{H}-\mathrm{F}$ Epsilon=.995)。リスク 選択率の時刻による変化を検討したところ、11 時:54.0\%, 13 時:57.4\%, 15 時:57.0\%, 17 時:55.9\%であ り、有意な差は認められなかった。前施行の結果毎に リスク選択率の時刻変化を検討したところ、大獲得後、 小獲得後、小損失後に時刻による変化は見られなかっ たが、大損失後では 11 時:53.6\%,13 時:59.6\%,15 時: $65.7 \%, 17$ 時: $65.3 \%$ と時間経過による増加を示した (Figure.1)。対比による時刻間の比較を行ったところ、 11 時と 15 時、 11 時と 17 時の間に有意な差が認めら れた。眠気とリスク選択率の関係を検討するため、課 題前の OSLER test の成績および自覚的眠気と、リス ク選択率との相関を求めた。その結果、全体、前試行 の選択結果に関わらず有意な相関は得られなかった。

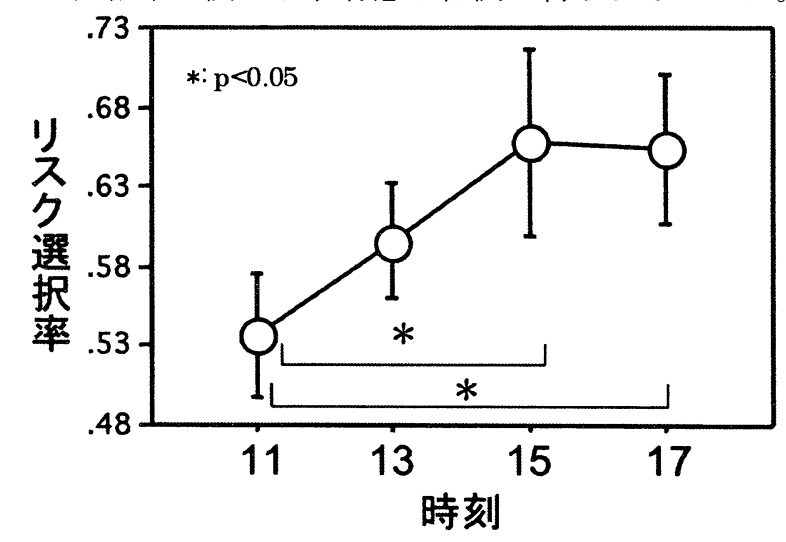

考察

Figure1. 大損失後のリスク選択率

ギャンブル課題におけるリスク選択率は、前試行の 選択結果に伴い変動するという先行研究と同様の結果 が得られた。負債を持った状態を嫌い、リスクを負っ てでも負債の解消を求めるリスク回避性が表れたもの と考えられる。リスク選択率に日内変動は認められず、 眠気との関係は自覚的、客観的ともに関連が見られな かった。しかし、前試行の選択結果毎に分析を行った ところ、大損失後のリスク選択率は、時刻の経過また は課題試行回数の累積に従って増加することが示され たため、リスク選択行動に何らかの日内変動が存在す ることが示唆された。今後、一日を通じた実験を行い リスク選択率の変動をさらに検討する必要がある。 


\section{アクチグラムによる睡眠判定の試み}

黒田 稔 (日本体育大学)

1. はじめに 最近, 睡眠障害の判定にアクチグラム (以下Act)が用いられ，保険適用されるようになった。Act は携帯性に優れ生体リズムの周期解析法としてペリオドグ ラムやオートコリログラム, FFT や MEM などを用いた睡眠 一覚醒リズム障害の判定にはかなり有効な手法である。睡 眠一覚醒や睡眠段階の判定には，一般的に睡眠ポリグラ フ(PSG)が用いられているが, PSG とAct との睡眠覚醒判 定の一致率は $95.5 \%$ で，その有効性は高いとの報告もあ る。しかし, PSGとAct との研究は主として, 睡眠効率や睡 眠潜時あるいは起床・就寝時刻と睡眠時間などである。 PSG は被験者のみならず実験者も負担が多く, 記録や判 定にも専門性が要求される。

著者はAct の無体動時間(silent time:以下 ST)の変動 経過を検討し, 睡眠の前半に持続時間の長い現象が多く, 後半にかけて漸減現象を示寸傾向を見出したことから， 今回は, 睡眠 stage をより簡易的な方法で判定する一手 段として活用するために, 睡眠時の Act から ST の変動経 過と PSG による睡眠段階の変動経過から, 入眠潜時と中 途覚醒等と睡眠段階 3 ・4との関係について検討した。

2. 方法 1) 被験者: 男子の成人 (60 歳) と大学生 $(20$ 歳)の計2名。2)調查内容:(1)Act は(ア师力AMI社製:XYZ 方向の $0.01 \mathrm{~g} / \mathrm{rad} / \mathrm{sec}$ 以上の加速度の頻度を $1 \mathrm{~min}$.毎に 計測: ZCA モード) 非利き手に装着し, 睡眠判定は actionW を用い, Cole らに基づき判定した。(2)PSG:脳波 の導出部位は $\mathrm{C} 3, \mathrm{C} 4, \mathrm{O} 1, \mathrm{O} 2$ と左右耳架(A1, A2)との 単極導出, 眼球運動 (左右眼瞼)・筋電図 (下顎筋)を記 録した。脳波判定は sleep sing(キッセイコムテック社製)を用い RechtschaffenによりC3を分析，視察判定を加えた。

\section{3. 結果と考察 1)Act による睡眠指標とST}

睡眠中のSTの持続時間は, Act から睡眠と判定された 期間の測定值「0」が持続する時間を求めた。(1)アーチフ アクトの除去:Act の測定器が腹部の上や身体の下にある 時(呼吸性等)のアーチファクトと考えられる「5」以下の数 值と, 実測值に「1・3・5」回が記録されていないこととから， 「5」以下の数值をアーチファクトとして削除した。(2)ST の 持続時間: 入眠時刻から計測值「0」が連続する回数とし た。今回の Ku は睡眠の前・中・後期に多いが, Tu では睡 眠中盤と後半に見られる。PSG の経過から深睡眠期と ST
の関係は, Ku においてはやや時間的なずれが認められ るが, Tu は, PSG の睡眠後半は stage $1 \cdot 2 か ゙$ 多く, 深睡眠 期と ST と必ずしも対応しているとは言えず, 今後, さらに 検討を加える (Figure 1)。2) PSG による睡眠様相と睡眠指 標の判定:(1)睡眠時間は 6.2-7.4hである。PSG の各 stage の出現率は stage 3 ・4が Ku(18.4\%)> Tu (12.4\%) と Kuは 平均的であるが Tu はやや少ない。 stage 2 は $\mathrm{Ku}(22.7 \%)$ $>\mathrm{Tu}(9.7 \%), \mathrm{MT}$ が $\mathrm{Ku}(6.2 \%)>\mathrm{Tu}(19.0 \%)$ と差が大で ある。しかし，両者とも stage1(約 35\%)が多く, REM が 7\% 以下と極端に少ない。特に Tu は起床後の内省から実験 室効果の影響や REM の判定基準によるものと考えられる。 (2)入眠潜時の判定:Act は actionW により睡眠指標による Sleep Latency 值とし, PSG は stage1が $5 \mathrm{~min}$.以上持続し た開始時刻とした。Act では $\mathrm{Tu}(31.0 \mathrm{~min})>.\mathrm{Ku}$ (7.0min.) であるが, PSG では Tu が 40.0min.と長く, Ku は 9.0min.と 短く, 両者とも両現象で類似した傾向を示した。(3)中途覚 醒の判定:Act は睡眠指標によるWE( Wake Episodes)值と Act 值「0」が5min. 以上持続した場合とし, PSG は MT の 回数とした。Act では Ku の WE は8回 (max.8min) $5 \mathrm{mn}$. が5回で, TuのWE は 14 回(max.10min) 5mn.が 11 回で ある。PSG での MT は Ku(25 回) < Tu(49 回)で, 両現象 の差は判定エポックタイムの差が考えられる。(4)睡眠効率 はAct では\%sleep 值を用い, Ku (93.03\%)> Tu (88.54\%) である。PSG では $\mathrm{Ku}(81.8 \%)>\mathrm{Tu}(64.7 \%)$ と差が大で, 中途覚醒時間の判定基準差も影響すると考えられる。

4. まとめ Act とPSG から睡眠 stage との関係を検討し， 入眠潜時は一致傾向を示したが，中途覚醒や深睡眠期と ST との出現時間にはずれが認められ, 今後, 諸現象の判 定規準や分析の設定条件などについて検討を加える。

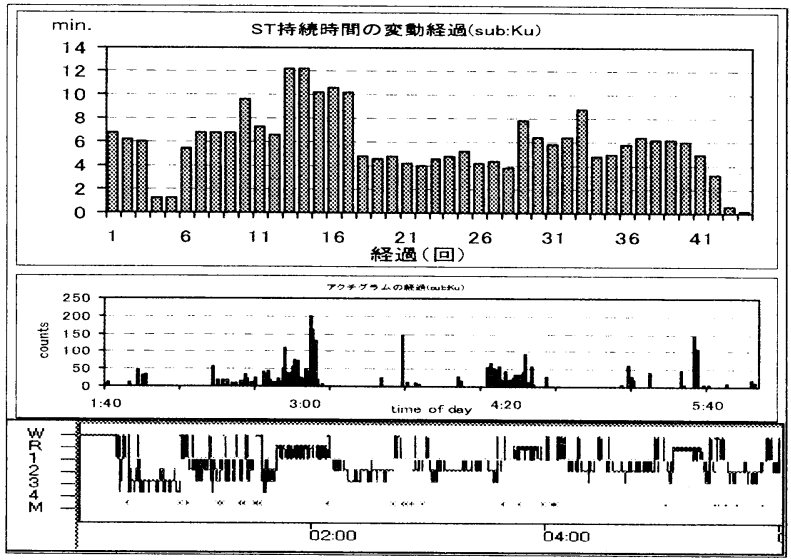

Figure 1．ST の持続時間の経過(上段:5point smoothing) Act の睡眠経過(中段)・PSG の睡眠段階(下段) 


\section{大学生における睡眠改善メニュの開発 \\ 〜日常生活下で睡眠健康教育と \\ 温熱湿布を用いた検討〜 \\ $\bigcirc$ 松尾藍(広島国際大学大学院総合人間科学研究科) \\ 田中秀樹(広島国際大学心理科学部) \\ 矢田幸博 鈴木敏幸(花王(株)東京研究所)}

\section{【はじめに】}

私達現代人の生活は大きく夜型に変わってきてい る. 夜型化は睡眠にも大きく影響を及ぼしている．30 年前には，7時間以下の睡眠をとる者が全体の $25 \%$ か ら最近では約 $50 \%$ にも増加している. 睡眠時間の短縮 化はどの世代にも見られることであるが, 16〜19歳の 思春期後半から青年期前半の世代がもつとも顕著であ り，高校時代に培われた習慣が大学に入学した後も持 続，あるい悪化するとも考えられる.

睡眠時間の短縮による睡眠不足は，注意集中の困難 化，記憶力の低下や気分の悪化という悪影響を及ぼす ことも報告されている。

また睡眠は，その量だけでなくリズムとしての側面 が重要であり，昼間に覚醒を保ち，夜にはぐっすり眠 るというリズムのメリハリが無くなると，夜更かし， 日中の眠気等の様々な問題が起こるとされている.

よって，本研究では，睡眠時間の規則性に焦点を当 て，睡眠問題を改善するための生活習慣メ二ュを開発 することを目的とする.また，乙のメ二ュを用いた睡 眠健康教育と併せて温熱湿布を用いて，日常生活下に おける睡眠の状態について検討を行うことを目的とす る.

\section{【方法】}

大学生 299 名を対象に, 睡眠・生活習慣に関寸る項 目で構成した質問紙を用いて調査を行った。睡眠時間 が規則的な者を規則群(66名)，不規則な者を不規則群 (66名)とした. 生活習慣項目について「すでに出来て いる」，「頑張れば出来そら」，「出来ない」の3件法で 記入を求め, 2 群(規則群と不規則群)を比較し, 睡眠を 規則的にするための生活習慣について検討した。

大学生 6 名を対象に, 質問紙調査で検討した睡眠改 善メニュを用いた睡眠健康教育と温熱湿布を併せた睡 眠改善効果を検討するため日常生活下で実験を行った. 実験期間中は，睡眠改善メ二ュの実践を行わせるとと もに，実験期間であった 6 日間のうち，2 日間は温熱
湿布を使用させた。 また，実験期間中はアクチグラフ の装着，睡眠日誌八の記入を求め, 活動量の測定を行 った．起床時には，OSA 睡眠感調査票（MA版）を用 いて，睡眠感についても調査した。

\section{【結果・考察】}

“睡眠の状態”について規則群と不規則群の両群を比 較した結果，規則群で「よく眠れる」という項目が， 不規則群で「朝起きられないという項目に回答する 割合が有意に多かった。

次に, “自覚疲労症状”についても両群で比較した結 果，「体がだるいり，「足元が頼りない」，「考えがまとま らない,「物事がやたら気になる」、「根気がなくなる」 の項目において不規則群で有意に回答した者の割合が 多汃た。

生活習慣の各項目について，“すでに出来ている”, “頑張れば出来そうだ”,“出来ない”に回答した者の割合 を両群で比較した. その結果, 規則正しい起床・就床時 刻・睡眠時間, 太陽の光, 夜食をとらない, といら項目に おいて, 規則群が不規則群に比ベて“すでに出来てい る”と回答した割合が多く, 不規則群よりも生活リズムが規 則正しいことが分かった。のことから，生活りズムの規則 性が睡眠時間の規則性につながっていると考えられる.

また，不規則群で規則群より“頑張れば出来そうだ” 上回答した割合が多かった項目は，「太陽の光を女び る」，「就床前の喫煙をしない」「ぬるめのお風吕につ かる」，「寝酒をしない」，「睡眠時間帯を不規則にしな いり 5 項目であった。睡眠が不規則な者に対して， これらの生活習慣項目を用いて，行動的アプローチを 行うこ上で，生活リズムが規則的になり，それが睡眠 の規則性につながっていくと考えられる.

日常生活下で上記の項目を用いて，睡眠健康教育と 併せて，温熱湿布を使用したアクチの一例を図 1 に示 した。 入眠が減少していることが分かり，今後，例数 を増やすとともに，睡眠改善メ二ュを用いた自己管理 法と温熱湿布の効果を検討する必要性が示唆された。

温熱湿布無し日

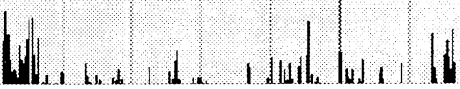

温熱湿布有り日

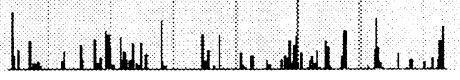

図 1 健康教育と温熱湿布を用いた夜間睡眠の改善例 


\section{高校生を対象とした睡眠改善プログラムに関する研究 〜教育現場での実践へ向けて〜}

○出下 嘉代 (広島国際大学総合人間科学研究科)

田中 秀樹 (広島国際大学心理科学部臨床心理学科)

\section{【目的】}

「24 時間社会」といわれる休息を知らない社会への変 化は, 大人だけでなく子どものライフスタイルの夜型化 をも促している。夜型化によって睡眠時間が短縮される のみならず，慢性的に生体リズムに反する不規則な生活 を送ることになる。

また，睡眠健康の悪化は，学習・記憶機能の低下

(Bonnet, 1994)，注意・集中力の低下 (Drake et al., 2001) につながり，不眠を主とする睡眠問題が健康を損ない， さらには行動や気分に悪影響を及ぼすことが指摘されて いる (Wolfson\&Carskadon, 1998)。

したがって，児童生徒の睡眠健康の悪化は，学校教育 にかかわる重要な問題とも関連するような健康管理上の 重要な課題であり, 思春期の心身の健康保全のために適 正な睡眠健康を確保寸ることが重要であると考えられる。 そこで，本研究では高校生を対象に(1)不規則な睡眠習 慣が心身の健康に及ぼす影響を検討し，(2)睡眠時間の規 則性に有効な生活習慣メニューを作成することを目的と する。

\section{【方法】}

調查期間 : 2004 年 12 月中旬 2005 年 1 月 対象 : 広島県内A地区 (17 校) の高等学校の生徒 アンケート：睡眠に関わる生活習慣（以下，睡眠習慣） や睡眠の状態，その他の生活習慣に対応した質問項目 (19 項目), 疲労自覚症状に対応した質問項目 (20 項目) から なる「高校生の生活リズムと睡眠に関する調查票」と， 睡眠に良好な生活習慣のポイントをまとめて作成した 「睡眠生活習慣行動調查票」を用いた。

分析 : 通常の家庭生活を送っている広島県 $\mathrm{A}$ 地区の高等 学校に在籍する生徒 4,665 名回答が得られた。的うち, 基本的睡眠習慣である起床時刻，就床時刻，睡眠時間に 記入漏れのない 4, 544 名を分析対象とした。規則性別比 較では,「睡眠時間は規則的ですか」という質問に対して, 「かなり規則的」であると回答した生徒 300 名を規則群, 「かなり不規則」であると回答した 606 名を不規則群と した。

統計的検定 : 数量化可能なものは $\mathrm{t}$ 検定を行い, その他 の項目についてはクロス集計表により出現頻度を算出し， $\chi^{2}$ 検定を行った。 $\mathrm{p}<0.05$ を有意水準とした。

\section{【結果・考察】}

高校生の $61.8 \%$ \% 24 時以降に就寝しており，66.7\% が 6〜8 時間睡眠であった。睡眠時間が「かなり不規則で ある」と回答した高校生は $13.5 \%$ ，「やや不規則」である と回答した生徒と合わせると, 高校生の $47.1 \%$ は睡眠時 間が不規則であった。睡眠時間が不規則な高校生は規則 的な高校生に比へ，就床時刻が遅く，睡眠時間が短いこ とが判明した。これらの結果より，睡眠時間が不規則な 高校生の方が夜型で, 睡眠の状態も悪く, 「熟眠感欠如」,

「入眠困難」,「中途覚醒」,「起床困難」,「起床時の疲労 感」を訴える割合が有意に高いことが判明した。睡眠時 間が不規則な高校生は睡眠の状態が悪く，質的にも量的 にも十分な睡眠が取れていないことが示唆された。

また，睡眠時間が不規則な高校生は疲労自覚症状を訴 える割合が有意に高いことが判明した。本研究において, 疲労自覚症状を 3 つの下位因子（「眠気とだるさ」,「注意 集中の困難」「「身体への疲労の投射」）に分類し検討した 結果，高校生は心身共に疲れており，「眠気とだるさ」は 授業を受ける体勢を整えることを困難にすることが示唆 された。ストレス対処法について，睡眠時間が規則的な 高校生は積極的な対処法をとっているのに対し，睡眠時 間が不規則な高校生は逃避・回避的な対処法をとってい ることが判明した。このことから，睡眠健康を改善する ことにより, 精神健康も改善される可能性が示唆された。

このような睡眠時間の不規則性による睡眠健康の悪化 を改善するため, 本研究においては, 睡眠改善に効果的 であると思われる生活習慣(21 項目)を挙げ，学校現場で 簡便な行動療法を用いてスリープ・マネージメントを行 うという観点から, 実際に指導可能な項目を絞り込むこ とを目的とし，各項目について規則群，不規則群の群間 比較を行った。

その結果，(1)生体リズムの規則性の確保のためには, 「毎朝ほぼ決まった時間に起きる」，「朝食を規則正しく 毎日とる」,「夜 9 時以降, コンビニなど明るいところへ 外出しない, 「就寝の 2 時間前までに食事を終わらせる」, 「夕食後に夜食をとらない, (2)日中や就床前の良好な覚 醒状態の確保のためには，「日中はできるだけ人と接触し て活動的に過ごす」，「趣味や部活動などを楽しみ，活動 的に過ごす」，「帰宅後は仮眠をしない」，(3)良好な睡眠環 境の整備のためには，「寝室を静かで適温にする」，(4)就 床前のリラックスと睡眠への脳の準備のためには「眠く なってから寝床に入る」という生活習慣が有効であるこ とが明らかになった。

以上の結果を踏まえ, 学校現場では行動変容を促しや すいと考えられる項目を挙げ (10 項目程度), スリープ・ マネージメントを進行している。 


\section{短時間昼梫·夕方の軽運動による 生活指導介入による睡眠改善 〜自律神経系活動の検討〜}

○井手原 千恵 (広島国際大学大学院総合人間科学研究科) 田中 秀樹 (広島国際大学 心理科学部)

荒川 雅志 (琉球大学 長寿科学健康ブロジェクト) 平良一彦 (琉球大学 長寿科学健康プロジェクト) 白川 修一郎 (国立精神·神経センター精神保健研究所)

\section{1. 問題と目的}

超高齢社会となりつつある我が国では，高齢者の3 人に 1 人が持つといら睡眠障害に対する取り組みは社 会的急務であると言える。また，らつの予測因子とも 言われることの多い不眠が改善することにより，精神 健康度が向上すること, さらには認知機能の低下を妨 げ，認知症予防に関する影響もあることが示唆されて いる。不眠の頻度が高いことを反映して，高㱓者にお いては睡眠薬学常用するものが多く，睡眠薬八の而性 低下の問題，また他の疾患の治療薬との併用などの問 題から，睡眠薬の投与が困難な場合も多い。したがっ て，高歯者の睡眠健康の為に性生活習慣の改善が重要 になってくる。近年の睡眠研究により，高齢者の睡眠 健康に関する生活習慣を改善させる方法として, 「適 切な時間に取る短時間の昼寝」や，「夕方の居眠りを しないこと」なよ゙，生活習慣指導による方法論の有用 性が明らかになってきている。実際に地域高齢者を対 象にアクチグラムを用い検討した研究では，「短時間 の昼寝」と「夕方の軽運動」による生活指導介入が, 睡眠効率や入眠潜時, 中途覚醒時間等が定量的に改善 することが報告されている。そこで今回，心電図によ り心臓血管系自律神経活動を測定することにより，睡 眠の重要な機能の1つである自律神経系の評価を行う ことを目的とした。

2. 対象と方法

A 県 B 町在住の高齢者を対象にし，地方自治体を通 じて睡眠の問題で困っている人の為の睡眠健康教室を 開催した。全 13 回の健康教室 (1 ケ月間)に 10 回以上 参加したものの内，心電図データに久損の無い 9 名の 高歯者 (平均年龄 $71.67 \pm 3.04$ 歳, 女性 8 名男性 1 名) を対象とした。介入前の 7 日間と, 教室最終日までの 7 日間それぞれで，対象者の非利き手に装着させたア クチグラフを用いて活動量測定を行った。得られた結
果より睡眠効率，中途覚醒時間などの睡眠健康度を介 入前後で評価した。心電龱測定は対象者の承諾が得ら れた後，教室開始 1 週間の間で 1 夜，第 4 週目の間で 1 夜ずつ測定した。得られた心電図 R-R 間隔から, MemCalc 法による心拍変動周波数解析を行った。

4. 結果と考察

定量的評価の可能なアクチグラフを用いて介入指 導の効果を検討した結果, 睡眠効率が増加しているこ とが確認できた。また，睡眠の前半では，介入後で中 途覚醒時間が減少していた。心電図 $R-R$ 間隔による心 臟血管系自律神経系活動は, 睡眠中の HF(副交感神経 活動)が増加した対象者は 9 名中 5 名いた。また, 睡眠 の前半では，9名中 6 名に HF の増加が見られた。さ らに, 個人内の特徵的な変化として, 介入後では睡眠 の前半で急激にHF が増加し，入眠に伴い副交感神経 活動が亢進し優位に切り替わる傾向が見られた (figure 1)。また, LF/HF(交感神経活動)においても, 介入後では，睡眠中に交感神経活動が抑制されること が認められた(figure 2)。これらのことより, 生活習慣 改善がもたらす睡眠に伴ら自律神経活動の入れ替え に関する影響が示唆された。

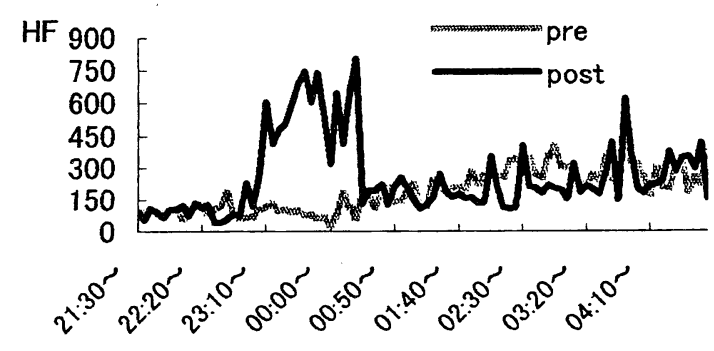

figure 1. 睡眠中HF(副交感神経活動)の変化 の1事例(71歳,女性)

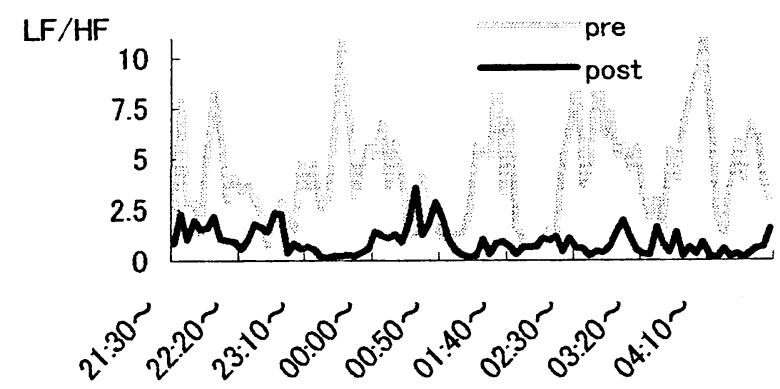

figure 2. 睡眠中LF/HF(交感神経系活動)の 変化の1事例(71歳,女性) 


\section{女性交替勤務者への香気成分セドロールを用いた スリープマネージメントの効果}

○原田恵美子 田中秀樹(広島国際大学 心理科学部

臨床心理学科 精神生理学研究室)

矢田幸博＼cjkstart鈴木敏幸（花王侏）東京研究所）

\section{【目的】}

交替勤務者は，サ一カディアンリズムの位相からず れたまま, 数年から数十年にわたって働かなければい けない。交替勤務に関連して起こるヒューマンェラー や事故の多くは，サーカディアンリズムに逆らつて作 業を続けることにより生じる, 疲労・作業能力の低下 によっておこる。それに伴い, 呼吸器や運動器などの 罹患が多いこと, 精神状態を悪化させやすいことが指 摘されている。この精神状態の悪化は, 燃え尽き（Burn -Out）, 勤労意欲の低下, 離職, うつ状態などをもたら す要因となる。夜勤・交替勤務は社会的に避けること ができないが，その勤務自体が通常の健康問題とは明 らかに異なった特異な問題を抱えている。交替勤務を 何年続けていても，精神健康を良好に保つためには， 慢性的な疲労の増大・休息不足を軽減する必要がある と考える。そこで, 本研究では，女性交替勤務者に， 香気成分セドロールを用いたスリープマネージメント を行い, 睡眠の状態, うつ状態, Burn-Out, お肌の状態, ストレス反応に対する効果の検討を目的とした。

\section{【対象・方法】}

広島県 $\mathrm{A}$ 病院の看護師 176 名の中から, 参加に同意 の得られた 11 名を対象とした。測定時期は，2004 年 11 月にスリープマネージメントを行い, 12 月までの 4 週間を測定期間とし，12月にフィードバックを行った。 スリープマネージメントの内容は，生体リズム・睡眠 のメカニズムについて, 交替勤務障害を中心とした睡 眠障害について, 簡便な行動療法を用いた睡眠の自己 管理方法についての説明を行い, その後, 実践可能で 継続できる生活習慣を, 相談のもと選択し立案した。 調査票は, 睡眠健康調査票（田中, 2004), エップワー ス眠気尺度 (Epworth Sleepiness Scale 睡眠健康力゙ イドブック, 2001), 自覚疲労症状 (Tanaka・Shirakawa, 2004 ; 田中, 2002), GHQ28, 看護婦・士の意欲 (今川, 2000), 睡眠生活自己評価票を, 一部, 看護師用に修正
したもの, SCL30 (ストレス反応尺度), お肌の状態調 査表を使用した。スリープマネージメントの効果を定 量的に評価するために, 血圧・心拍測定, お肌の水分 量測定 (SEKISUI Sittorisan 販売元 : 積水化学工業 株式会社）を行った。介入中は，4週間の活動量を客 観的に測定するために，昼夜活動量测定（アクチグラ ム AMI 社 マイクロ・ミニ 以下，アクチグラムと 略す）を, 非利き腕の手首または足首に装着するとと もに，睡眠日誌および，意欲・日中の眠気の記入を行 い, 希望者の 8 名には, 香気成分のセドロール揮散器 の貸し出しを行った。

\section{【結果】}

スリープマネージメント後, 平日の入眠潜時が 32 分から 12.5 分に減少 $(\mathrm{p}<.001)$, 熟眠感, 自覚疲労 症状「眠気とだるさ」においても, 有意に改善が認め られた。また, セドロール使用者は, 夜勤明けの仮眠 の入眠潜時が 125 分から 18.4 分に減少し, 準夜後の睡 眠では 162 分から 17 分に有意に減少が認められた。 れらのことより,夜間, 質の良い睡眠がとれることで, 日中の「眠気とだるさ」が減少していると考えられる。 さらに，入眠潜時・中途覚醒を，アクチグラムを用い 客観的に検討した結果, スリープマネージメント後は, 夜間の中途覚醒の減少や十分な睡眠量が確保できてい るとことが定量的にも確認できた。

睡眠の質的改善に伴って,「入眠潜時の満足度」は $60 \%$ 人に，「熟眠感の満足度」は $90 \%$ のに，「日中の スッキリ度」は $90 \%$ のに, 有意に改善が認められた。

また「顔がほてる」は $80 \%$ の人に「顔が青白い」 は 80\%の人に，など肌の改善も認められた。ストレス 反応においては，「立ちくらみ」は $66 \%$ 人に，「疲れ がとれない」は $62.5 \%$ 人に，「朝起きられない」は 57. $1 \%$ の人, GHQ「うつ状態」は $100 \%$ のに, Burn-Out 得点は $90.9 \%$ のに，有意な改善が認められた。

身体と心は切り離して考えることは難しく, 睡眠不 足から疲労が改善されず, それが慢性的な疲労の増大, イライラ感・活気の低下などの要因となると考えられ る。生活習慣の改善から精神健康の改善が認められた ことにより, 看護師の Burn-Outには, 心理的な不適応 だけから生じるのではなく, 生活習慣（交替勤務）が 精神健康に与える影響は大きいと考える。 
夜間における異なる波長での光照射が、主観的睡眠感 および睡眠覚醒リズムに与える影響

○田中 睦如 (福島大学大学院教骨学研究科)

福田 一彦 (福島大学共生システム理工学類)

\section{1. 目的}

夜間に目から入る光の波長と、メラトニンや梁部体温リズ ムの関係についての研究から、短波長の光の方が生物り ズムの位相に強く影響を与えることが分かっている。

Lockley ら(2003)は、長波長 $(555 \mathrm{~nm})$ の光に比へ、短波長 $(460 \mathrm{~nm})$ の光がメラトニンリズムの位相を2倍以上後退さ せることを示した。しかし、社会的要因など他の要因と比 較して、光暴露の挿入がどれほどの影響力を持っている かどうか、検討は少ない。また、Burgessら(2004)は、固定 的な睡眠習慣をもった人において、DLMO（薄暮光の条 件の下でメラトニン分泌が開始する時刻) と就床時刻との 間に、 $\mathrm{r}=0.49$ の相関があることを示した。これらのことは、 マスターペースメーカー $(\mathrm{SCN})$ が短波長の光に強く反応 することを示唆する一方、その影響が通常生活を行って いる人の睡眠覚醒リズムにおいても同様であるか、結論を 出せる状況ではないことを示している。

本研究では、睡眠覚醒リズムと主観的睡眠感を指標と し、できる限り通常の生活を保持した状態、つまり社会的 要因などの干渉があると考えられる状況において、夜間 の光暴露が睡眠覚醒リズムに与える影響と、その波長の 違いによる効果の差について検討寸ることを目的とした。

\section{2. 方法}

睡眠覚醒リズムが大きな乱れがなく、健常な大学生 3 名 (男性1名)を被験者とした。光源は、松下電工の FL20S・ $\mathrm{R}$ 及び FL20S・B を使用し、約 $660 \mathrm{~nm}$ の波長を最も多く含 む長波長の光を赤色光条件、約 $440 \mathrm{~nm}$ の波長老最も多く 含む短波長の光を青色光条件とした。照度は前額面でそ れぞれ 10001x に固定した。実験手続きは、各被験者とも に、照射第1セッション (7日間)、ウォシシュアウト期間 $(7$ 日間)、照射第2セッションの順に行った。第1セッションと 第2セッションで波長の条件をかえ、また被験者ごとに条 件の順番を入れ替える被験者内計画とした。被験者の睡 眠覚醒リズムは睡眠表及び actiwatch®で、主観的睡眠感 はOSAをもとに作成した質問紙により測定した。分析にあ たり、7日目をダミーとし6日分のデータを使用した。
3.結果

主観的睡眠感に関する因子ごとに6日間の平均值を比 較したところ、「入眠の因子小において青色光条件の得点 が低い傾向がみられた。点数は高得点なほど睡眠感が良 好であるとなっており、青色光条件において入眠、つまり 寝つきが悪いと判定されたと言い換えられる。また、青色 光条件下では就床時刻がやや遅くなり、赤色光条件下で は早まる傾向が見られた。それに伴って、行動量のリズム において青色光条件期間の前半から後半にかけ、就床 時刻付近での位相が後退し、逆に赤色光条件下では同 じく就床時刻付近で前進する傾向が見られた。しかし、被 験者が少ないため、すべての分析において統計的な分 析をかけることはできなかった。

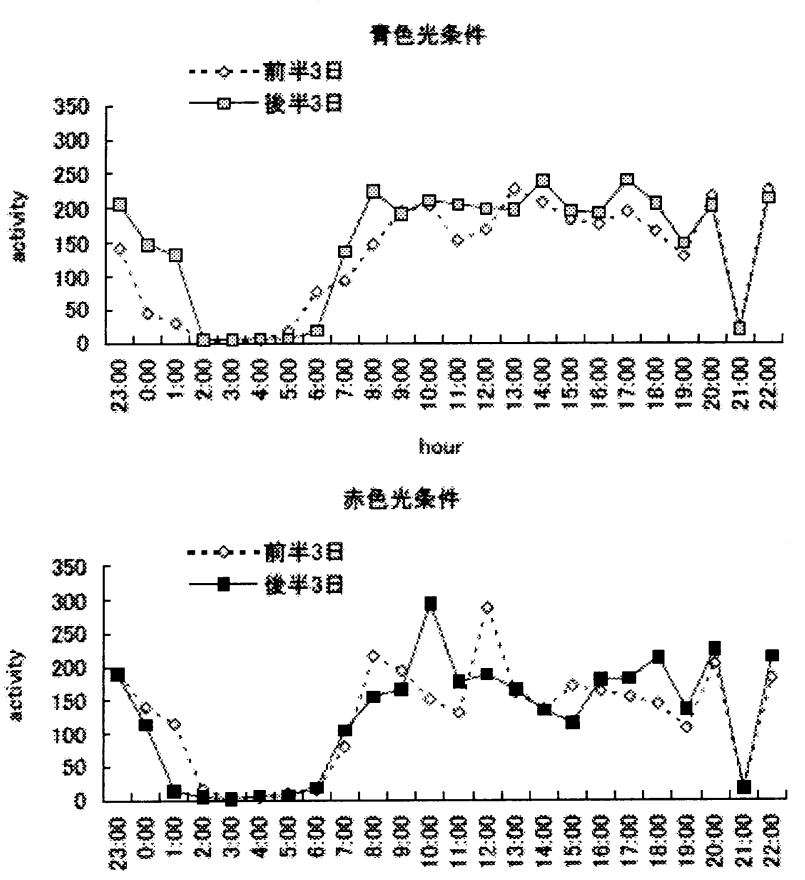

Figure 1. 活動量少ズムの推移

\section{4. 考察}

多くの先行研究から、ホルモンや体温における短波長 光の影響力の強さが示されてきた。今回は、夜間におい て目から入る短波長光が通常の生活に挿入された場合 においても、睡眠覚醒リズムに影響する可能性が示唆さ れ、さらに短波長光によって後退させる影響力が強いこと が示された。しかし、被験者が少ないため偶然である可能 性も否定できず、さらに赤色光条件での位相前進など、 説明の難しい結果を含んでいる為、被験者を増やしての 更なる検討が課題となった。 


\section{自律訓練法が夜間睡眠に及ぼす効果（1） 睡眠段階潜時への影響}

佐藤 俊彦（東北文化学園大学医療福祉学部）

本研究の目的は, 自律訓練法が夜間睡眠に及ぼす影 響について，脳波などの客観的な生理指標の測定を通 して明らかにすることである。

自律訓練法を実施することの効果として，脳波の徐 波化が挙げられており（松岡洋一・松岡素子, 1999）, これに関連して, 自律訓練法の適用によって夜間睡眠 が改善するとの知見も少なからず報告されている（例 えば，村上他，2000）。だが，自律訓練が夜間睡眠に与 える影響についての過去の報告の多くは, 研究協力者 の主観的な評価に基づく知見であり，脳波などの客観 的生理指標を用いて, 自律訓練法の夜間睡眠への効果 を検討した研究は少ない。そうした中で, Coursey ら

（1980）は，慢性的に入眠に困難のある患者を対象に 脳波を指標とした実験を行い，一定期間練習して自律 訓練法を習得することによって，入眠潜時に顕著な影 響があったことを報告した。

そこで本研究では, 大学生が入眠前に自律訓練法を 実施した場合にも，入眠を促す効果があるかどうかを 検証するとともに, より深い睡眠段階への移行の速さ に与える影響ついても明らかにしたいと考えた。今回 の発表では，睡眠段階潜時に関する結果を中心に報告 する。

\section{方 法}

実験参加者 大学生の男子 3 名, 女子 3 名, 合わせ て 6 名であった。今回の参加者として, 自律訓練法を 習得するための日常的な練習を 4 週間以上経験した者 のみを対象とした。したがって，いずれの参加者も， 本研究に参加して自律訓練法の練習を開始した時点で, 自律訓練法に関する基本的な知識と経験を有していた。

装置と手続き 睡眠ポリグラフ検査には, 脳波計 (日 本光電 Neurofax EEG-1714） とその睡眠検査用オプ ション（スリープアプニアユニット JE-912A），なら びに寝具一式を用いた。測定指標は, 脳波 $4 \mathrm{ch}\left(\mathrm{C}_{3}\right.$, $\mathrm{C}_{4}, \mathrm{O}_{1}, \mathrm{O}_{2}$ ) の他に, 眼球運動（EOG）, 下顎部筋電 図, 心電図,ならびに上肢と下肢の運動などであった。 各参加者につき, 3 回の終夜睡眠測定に協力を依頼し た。1 回目の測定では, すべての参加者で順応夜とし
た。2 回目と 3 回目のいずれか一方をポリグラフ測定 開始直前に自律訓練法を実施する条件 (AT 条件), も う一方は暗算を行う条件（MA 条件）とし, 実施順序 はランダムに割り当てた。実験当日には, 各参加者に 電極の装着などを行った後, 深夜 0 時に消灯して終夜 睡眠の測定を開始し，午前 8 時に測定を終了した。終 夜睡眠の測定開始 10 分前から, AT 条件では, 自律訓 練の重感および温感練習を自分のペースで 5 分間行う よう依頼した。他方, MA 条件では, 暗算の課題を 5 分間行うよう依頼した。

データ分析 脳波解析には，睡眠脳波解析プログラ ムである Polysmith（Neurotronics 社）を利用した。 このソフトによるステージ判定結果を参照しながら, 睡眠段階判定国際基準 [Rechtschaffen \& Kales (Eds.), 1968）と，これに対する補足定義と修正（日本睡眠学 会, 2001）に従って, 最終的な視察判定を行った。そ こで得られた睡眠段階潜時の結果を, SPSS Ver13.0J を用いて, 対応のある $t$ 検定により条件間で比較した。

\section{結果 と考寀}

ここでは各睡眠段階潜時への影響について報告する。 睡眠前に自律訓練法を行った AT 条件では，同じ時間 帯に暗算を行った MA 条件に比べて, 段階 REM を除 く他のすべての睡眠段階潜時がいずれも有意に短縮し ていた。(ps<0.05, Figure 参照)。

今回の実験結果は, 入眠前の自律訓練法実施によっ て，一般の大学生でも入眠が促されるだけでなく，よ り深い睡眠段階への移行が比較的速やかに進む効果が ある可能性を強く示唆している。

\section{Latency to sleep stages ( $\mathrm{min}$ )}

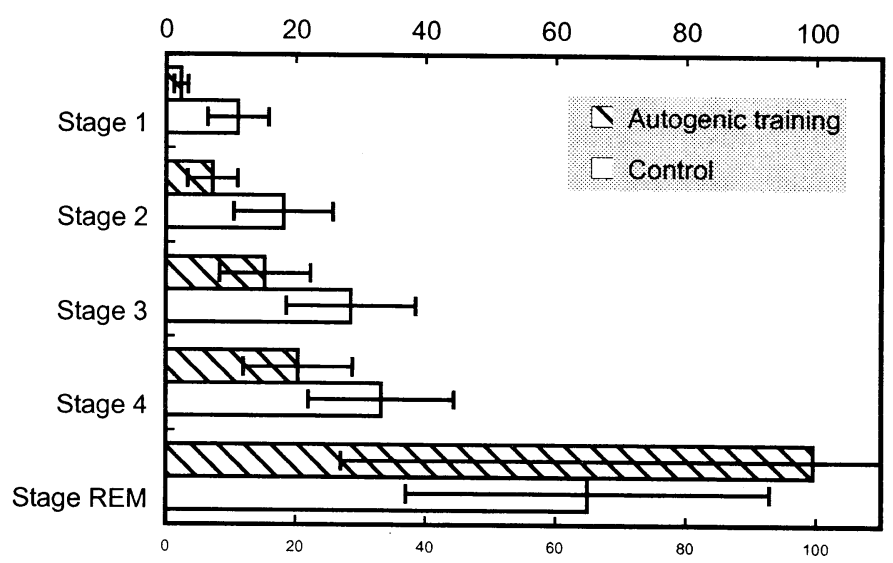

Figure．条件間の各睡眠段階潜時の差異。 
就床前のストレスと自律神経活動との関連

○古谷 真樹・田中 秀樹

(広島国際大学心理科学部)

\section{【目的】}

最高体温時点（消灯約 3 時間前）で一過性に体温を 上昇させる夜の運動や入浴は, 入眠潜時の短縮や徐波 睡眠の増加を導くことが明らかにされている(Yoshida, et al., 1999)。また，不安をはじめとする心理的スト レスと入眠潜時の延長との関連も示されており（古谷 ら, 2006), 就床前の過ごし方が睡眠の質に影響するこ とが指摘されている。本研究では, 日常生活における 就床前のストレスと睡眠の質との関連について自律神 経活動から検討した。

\section{【方法】}

対象者: 大学生 22 名（男女各 11 名, 平均 $20.4 \pm 0.79$ 歳）を対象とした。被験者には, 事前に研究の主旨と 方法などを説明し，実験参加の同意を書面で得た。

手続き: 被験者には, 1 週間睡眠・ストレス日誌の記 入とアクチグラムの装着を求めた。さらに, 消灯前後 の心身の状態を客観的に測定するために，携帯型心電 図を用いて自律神経系の活動を測定した。

質問紙: 睡眠・ストレス日誌では, 睡眠関連事項とし て, コード化した 1 日の行動および就床時刻, 起床時 刻, 中途覚醒回数, 入眠潜時の記録を求めた。 1 日の 状態評価 (快, 緊張, 怒り, 興奮, 眠気, 集中, 不安, 疲労）について 100 点満点での評価および各状態を経 験した時点においても 100 点満点で評価を求めた。

生理指標 : アクチグラム (Micro-Mini R 型，サニタ製） および心電図 (AC-301，GMS 社製）を用いた。心電図 データについては，R-R 間隔から，心拍数と高周波成 分 $(\mathrm{HF}: 0.15-0.4 \mathrm{~Hz})$ ，低周波成分 ( $\mathrm{LF}: 0.04-0.15 \mathrm{~Hz})$ および $\mathrm{HF}$ の比（LF/HF）について 5 分ごとの平均値を 算出した。

分析と統計：消灯前後の自律神経系の変化について, 心電図装着日におけるストレスの程度と時間経過によ る二元配置分散分析を行った。また, 両群でこの日の 夜の睡眠健康に違いがあるか，さらに，1 日を日中と 就床 2 時間前に分けて, 各時点のストレス経験頻度の 程度から睡眠健康について $t$ 検定を行った。

\section{【結果と考察】}

消灯前後の自律神経系の活動について，ストレスの 程度による違いを検討した。その結果, 消灯 25 分から 10 分前は, ストレス高群の方が低群よりも LF/HF の值 が高く, 消灯に近づくにつれて LF/HF の值の低下が示 された (Fig. 1 上)。消灯後は, 両群とも時間経過と ともに LF/HF の值が低下した（Fig. 1 下）。これらの 結果から，1 日のストレス評価が高かった者は，消灯 前の緊張が高いことが確認された。

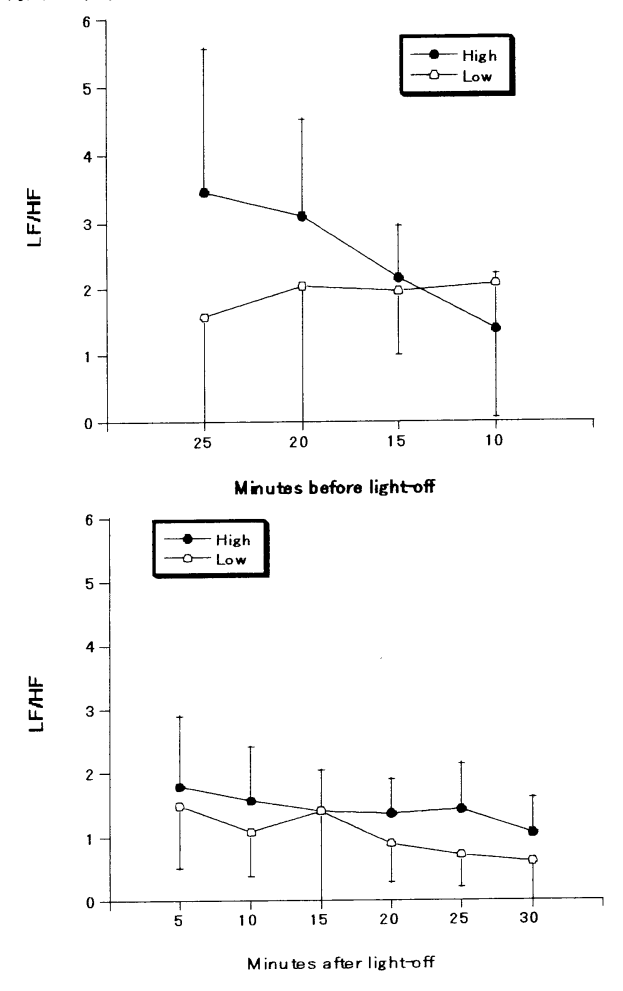

Fig. 1 ストレスの程度による消灯前後の LF/HF の推移

次に，心電図装着日の夜の睡眠健康を検討した。その 結果, ストレス高群は低群よりも入眠潜時が長く $(t=2.48, d f=4, p<.10)$, 中途覚醒も多い $(t=2.10$, $d f=14, p<.10)$ 傾向があった。さらに, 睡眠健康 と関連するストレスは，日中か就床 2 時間前かを検討 した。その結果，1 日全体及び日中では，ストレス経 験の程度で違いは見られなかったが, 就床 2 時間前の ストレス経験が多かった群は少なかった群よりも，入 眠潜時が長かった $(t=2.36, d f=7, p<.05)$ 。

これらの結果から，質の良い睡眠を得るためには， 就床 2 時間前から心身ともにリラックスをして, 睡眠 を導入しやすい環境を整えることが必要であることが 示唆された。 
大学生の試験ストレスが睡眠中の呼吸性不整脈に及 ぼす影響

○榊原雅人(東海学園大学人文学部)

早野順一郎(名古屋市立大学大学院医学研究科)

\section{目的}

吸気時に心拍数が増加し、呼気時に心拍数が低下 する現象は呼吸性不整脈 (respiratory sinus arrhythmia: RSA)と呼ばれ、肺のガス交換効率を高 める働き(生理的死空や肺内シャントの低下)をもつ ている (Hayano et al., 1996)。一般に、安静時・ 睡眠時では心拍数や呼吸数が減り、生体機能はエネ ルギー消費を抑制する方向にあると考えられる。こ の際、RSA はガス交換に有効な心拍を残す(逆に無 効なものを減らす)ことによって、ガス交換を犠牲 にすることなくエネルギ一節約に貢献しているとい える。さらに、RSA は安静状態(仰臥、リラクセー ション、睡眠)で増大する事実などから、生体の休 息に関わる機能であることが示唆されている (Hayano \& Yasuma, 2003)。本研究は大学生の定期 試験における睡眠中の RSA を測定し、日常的なス トレスが生体の休息機能に及ぼす影響を検討したの で報告する。本検討は睡眠中の脈波を記録し、脈波 間隔の変動から RSA を推定する方法を採った。

方法

被験者: 健常な大学生 17 名(男性 8 名、女性 9 名、平均年齢 $20.6 \pm 1.06$ 歳)を対象とした。手続 き: ベースラインとして定期試験開始約 1 週間 前、試験(初日)前夜、試験(初日)当夜の睡眠中の 脈波を自宅にて测定した。脈波測定の直前に、そ の日の行動概要、状態不安尺度、入眠感調査票(山 本ら，2003) への記入を求めた(入眠感調査票の一 部は起床後にも記入)。なお、試験第二日目には すべての被験者が受験予定のないことを予め確認 した。8 名の被験者(男性 4 名、女性 4 名)は春学 期試験(7月)において、9 名の被験者(男性 4 名、 女性 5 名)は秋学期試験(1月)において測定した。 装置および測定：脈波測定、脈波間隔計測、データ 保存の機能を搭載した小型脈波センサ([株]DENSO) を用いた。データ処理 : 脈拍間隔データは専用ソフ トウェアによってセンサからパソコンヘダウンロー ドし、FFTによるスペクトル分析を行った。

\section{結果}

3 名の被験者は試験前夜の睡眠時間が極端に短 かったことから、これらのデータを分析から除い た。各測定日のデータ計測時間、除外データ数(ア 一チファクト数)に差はみられず、測定データの 97\%程度を分析に使用した。試験前夜では、状態 不安得点が有意に増加し $(p<.01)$ 、入眠感尺度の 第一因子得点が有意に上昇した $(p<.01)$ 。また、 同尺度の第二因子得点は減少する傾向をみせた $(p<1)$ 。 Fig.1 は、ベースライン、試験前夜、試 験当夜における脈波間隔変動 LF 成分、HF 成分 のパワーの変化を示している。LF 成分には変化 がみられなかったものの、HF 成分は試験前夜に おいて有意に低下した $(p<.05)$ 。

\section{考察}

試験前夜の状態不安得点の増加および入眠感尺度 第二因子(就眠環境に関する因子)得点の低下傾向 は、試験に関わる心理的ストレスを反映したものと 考えられた。また、入眠感尺度第一因子(日中の精 神的・身体的状態に関する因子)得点は試験前夜で 増加しており、このことは試験前日の精神・身体的 負担が他に比して明らかに少ないことを示してい る。脈波間隔変動の結果からは、呼吸性不整脈を反 映する HF 成分の低下がみられ、試験前夜の睡眠 中は概水副交感神経活動が低下し、かつ生体の休 息機能が阻害されていることが示唆された。試験 当夜、HF 成分のパワーは回復する傾向にあり、 このような睡眠中の自律系の振る舞いは、日中の 精神的・身体的負担よりも、むしろ翌日に控えた ストレス状況に反応しているようにみえた。

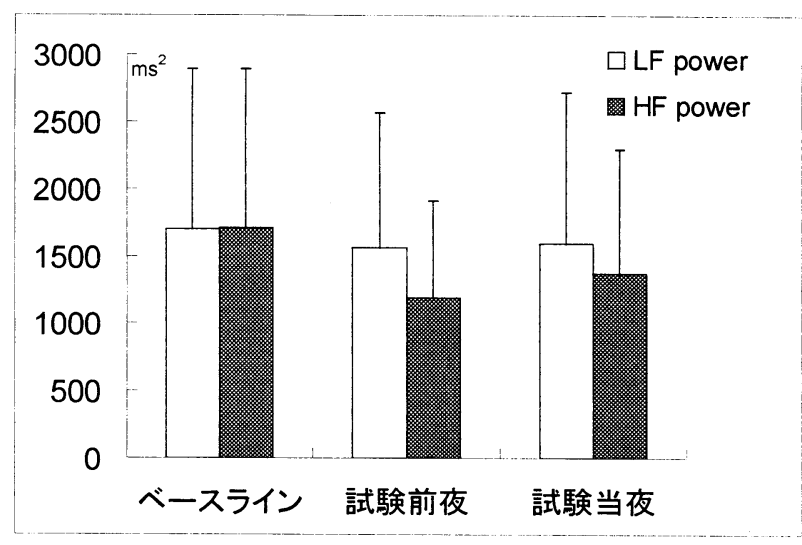

Fig. 1 定期試験 (初日) 前後の脈波間隔変動 


\section{薄明視状況における眼球停留関連電位 ○澤 友輝 (関西学院大学大学院文学研究科)}

藤本 清 (関西学院大学大学院文学研究科)

八木 昭宏 (関西学院大学文学部)

\section{研究の目的}

薄明視とは，明所視よりも暗く，暗所視よりも明る い見えのことである。薄明視状況の日常例として, 日 没前後の野外や, 夜間照明された道路環境が挙げられ る。眼球停留関連電位 (eye fixation-related potential：EFRP) における潜時が約 $100 \mathrm{~ms}$ で, 後頭 部で優位に出現する正の成分をラムダ反応という。ラ ムダ反応は, 刺激面が明るくなるにつれ潜時が減少し, 振幅が増大する (Gaader et al., 1964：Billings, 1989)。

薄明視では，錐体と桿体がともに働いている。錐体 は桿体よりも, 短い時間で照度への順応を終える。錐 体が順応し, 桿体が順応を終えていない条件（順応前 条件）と，錐体と桿体が順応を終えている条件（順応 後条件）とを比較することで, 桿体の順応の影響が見 られると考えられる。本研究では, 薄明視状況でのラ ムダ反応の検出を試みるとともに, ラムダ反応が照度 への順応の影響をうけているか否かを検討した。

方法

被験者は大学生 10 名であった。被験者はインフォー ムドコンセントを通じ，実験参加に同意した。

照度 $1401 \mathrm{x}$ を統制条件とし，41x と $11 \mathrm{x}$ の薄明視 を実験条件とした。薄明視には順応の前後を比較する

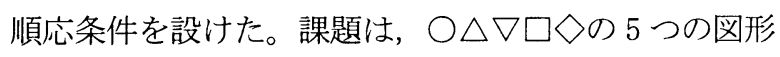
を用いた図形照合を行うことであった。

$140 \mathrm{~lx}$ 条件を行った後に, $4 \mathrm{~lx}$ 条件と $1 \mathrm{~lx}$ 条件を 行った。4 lx 条件と $1 \mathrm{~lx}$ 条件の順序は, 被験者ごと にカウンターバランスを行った。

EEG の導出部位は Pz と $0 z$ であった。基準電極は両 耳架結合で行った。EOG は両眼眼裂外に 1 対, 右眼眼 窩上下縁部に 1 対装着して双極導出を行った。EEG, EOG ともに，時定数は $2.0 \mathrm{~s}$, 高域遮断周波は $100 \mathrm{~Hz}$ ，八 ムフィルタを使用し, サンプリング周波数 $500 \mathrm{~Hz}$ で記 録した。サッケードの終了時点を基準とし, 基準前 100 $\mathrm{ms}$, 基準後 $250 \mathrm{~ms}$ において加算平均処理し, EFRP を 算出した。サッケード距離が 15 。に達しないものと アーティファクトが混入しているものを加算平均処理
から除外した。

結果

Fig. 1 で照度条件における EFRP 波形を示した。繸軸 は振幅を，横軸は潜時をあらわしている。ラムダ反応 の潜時について, 照度条件 (3) の 1 要因分散分析を行 ったところ，照度条件の効果は有意であった（F $(2,18)=15.74, p<.001)$ 。

ラムダ反応の振幅について, 照度条件（3）の 1 要因 分散分析を行ったところ, 照度の効果は有意であった $(F(2,18)=7.26, p<.005)$ 。

順応の影響は, ラムダ反応の潜時にも振幅にも見ら れなかった。

\section{考察}

すべての条件において，ラムダ反応を検出すること ができた。照度が低いほど，ラムダ反応の潜時が増加 し，振幅が減少することが確認され，Gaader et al. （1964）やBillings（1989）の報告が支持された。

順応の影響が現れなかったことから, 順応が照度変 更直後に完了していたことが示唆された。また、桿体 の影響が少ない照度条件であった可能性や，ラムダ反 応では順応の影響が出現しない可能性も示された。

今後は，さらに照度を下げて実験を行い，ラムダ反 応の潜時が増加し続けるのか一定の潜時でとどまるの かを，検証する必要がある。また，順応の影響を調べ るには, 順応時間を短く設定し, 暗所視に近い照度で, 実験を行う必要がある。

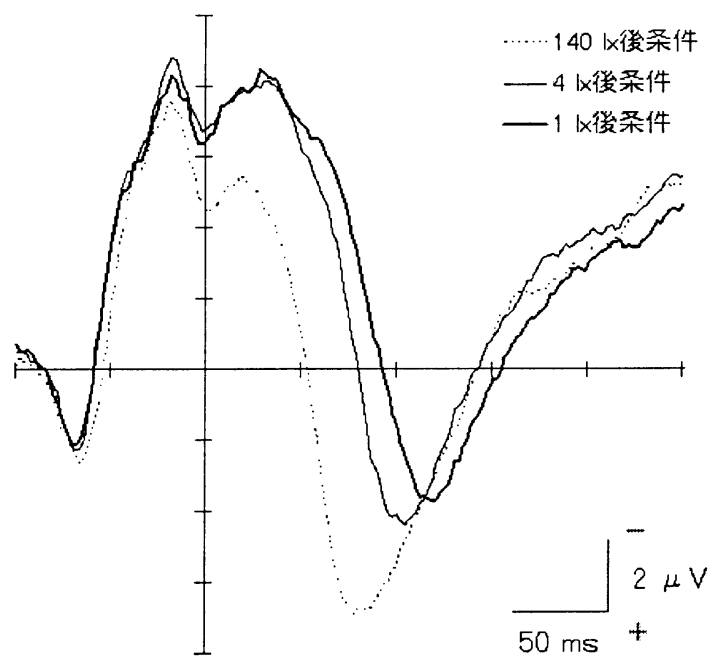

Figure 1．照度条件における EFRP 波形。 


\section{レム睡眠中の急速眼球運動開始点に同期した陽性電位}

○小川景子 (早稲田大学スポーツ科学学術院・日本学術振興会)

入戸野 宏 (広島大学大学院紿合科学研究科)

山崎勝男 (早稲田大学スポーツ科学学術院)

堀 忠雄 (広島大学大学院総合科学研究科)

睡眠中の夢は，ハンレム睡眠中よりもレム睡眠中で よくみることが知られている。また，レム睡眠中には 急速眼球運動が生じることから, 夢と急速眼球運動の 関連が指摘されている。本研究では，急速眼球運動に 伴う大脳皮質活動(事象関連電位)を検討することで, レ ム睡眠中(夢見体験中)の脳内活動について検討を行う。

先行研究により, レム睡眠中の急速眼球運動に関連 して，覚醒中の視覚情報処理活動を反映するラムダ反 态[1]と出現形態が類似したラムダ様反応が後頭部優勢 に出現することが観察され，レム睡眠中に何らかの視 覚情報処理活動が生じる可能性が示されている[2,3]。 また,発表者らはレム睡眠中のラムダ様反応が覚醒中 と同様に，急速眼球運動が止まった時点に関連するこ とを報告した $[3]$ 。他方，急速眼球運動の開始点に関し ても特有の脳電位活動が生じることが報告されている [2]。本研究では, 急速眼球運動の開始点と終了点に伴 う脳電位を直接比較することで，特に眼球運動の開始 に同期した大脳皮質活動に注目してレム睡眠中の脳内 活動を検討する。

\section{方法}

実験参加者 健康な大学生 9 名(男性 5 名, 女性 4 名)。 手続き 実験参加者の通常就床時刻から通常起床時刻 までの終夜ポリグラフ記録を行った。レム睡眠中のラ ムダ様反応の記録に充分な加算回数が得られるまで睡 眠実験を行った．参加者は 1-3 晚の実験に参加した。

記録・分析 脳波は 26 部位から $\mathrm{C} 3-\mathrm{C} 4$ の平均電位を 基準電極として記録し，分析時には両耳架連結

（A1-A2）に再基準化を行った。時定数は $5 \mathrm{~s}$ とした. 水平眼電図は両眼角外から，垂直眼電図は左眼窩上下 から時定数 $5 \mathrm{~s}$ と $0.03 \mathrm{~s}$ で双極導出した。八イカット フィルターは $300 \mathrm{~Hz}$, サンプリング周波数は $1000 \mathrm{~Hz}$ とした。レム睡眠中の急速眼球運動は覚醒中のサッカ 一ドをもとに個人ごとに，4段階(-5, 6-10, 11-15, 16-20 度に分類した。基準となる覚醒中のサッカードは，就
床前, 暗室内で, 刺激呈示ボード上の左右ランダムな 位置に点灯する発光ダイオード光点を追跡する課題を 行うことで記録した。光点の間隔(眼球運動幅)は, $5,10,15,20$ 度の 4 種類設けた。脳電位は, 視角度ごと に眼球運動開始・終了前 $400 \mathrm{~ms}$ から後 $400 \mathrm{~ms}$ を開始 点・終了点でそれぞれ揃えて加算平均して求めた。べ ースラインは加算平均区間の最初の $300 \mathrm{~ms}$ 間とした。

\section{結果・考察}

レム睡眠中のラムダ様反応について，急速眼球運動 の開始点に揃えて算出した場合, 潜時は視角度が大き くなるほど長くなったが，終了点に揃えた場合は有意 な差はなく一定であった。従って，レム睡眠中には覚 醒中と同様, 急速眼球運動の終了点に関連してラムダ 様反応が出現することが確かめられた。

急速眼球運動の開始点に伴う脳電位について検討し たところ，開始点から潜時約 $200 \mathrm{~ms}$ に頂点もつ陽性電 位 (P200r)が中心部優勢に出現し, 潜時は視角度に関係 なく一定を示した。終了点で加算した場合の陽性電位 潜時は視角度が大きくなるのに伴って小さくなった。 この結果は，P200r が開始点に関連することを示す。 また, P200r 振幅は視角度が大きくなるにつれて有意に 大きくなった $(p \times .01)$ 。この結果は, 急速眼球運動の開 始時点に急速眼球運動の振幅に関する情報がすでに存 在することを示しており，その情報が大脳皮質活動に も反映されている可能性を示す。P200r に相当する陽 性電位は覚醒中には観察されなかった。

本研究結果より,レム睡眠中には急速眼球運動の開 始に同期して特有の脳内活動(P200r)が生じ, 振幅は急 速眼球運動情報を反映していることが示された。レム 睡眠中の急速眼球運動が脳幹由来の発生機構をもつと する知見が報告されていることから 4$] ，$ レム睡眠中に は, 脳幹の㗢きによって急速眼球運動が出現し, 同時に 脳幹由来の大脳皮質活動も生じていることが考えられ る。この一連の活動過程は，レム睡眠中の夢の生成過 程と密接に関連すると考えられる。

\section{引用文献}

[1]Yagi, et al. 1979 Biological Psychology, 8 235-238

[2]Miyauchi, et al. 1987 Electroencephalography and Clinical Neurophysiology, 66.383-390

[3] Ogawa, et al. 2005 Sleep, 28 1077-1082

[4]Baghodoyan, et al. 1985 Sleep: neurotransmitters and Neuromodulators, 15-27 


\section{心的視覚イメージの生成及び走查過程に関わる} 脳活動の時間的側面からの検討

○山崎 圭子 片山 順一

(北海道大学大学院教育学研究科)

心的イメージは刺激入力の無い状態での知覚的体験と 定義される. 視覚イメージに関わる過程として「生成」 は視覚的記憶を引き出して表象を形成する働き，「走 查」はその表象を検索する働きであると考えられてい る. 本実験ではこの生成と走查の時間的な関係, 及び それに関わる脳活動について検討した.

\section{方 法}

被験者 大学生, 大学院生 12 名（男 6 名, 女 6 名)

刺激 Cue 刺激は $5 \times 5$ のマス目の中央にアルファベッ トの小文字があるもの, Probe 刺激は同様のマス目の 一つにメ印がついたものを使用した，小文字は，大文 字をイメージしたときに単純な形のもの（t, 1), 複雑 なもの $(\mathrm{g}, \mathrm{s})$, 更に記憶による反応を防ぐため 2 文字 (c，u）を用いた.

手続き Cue 刺激を $100 \mathrm{~ms}$ 呈示後すぐに Probe 刺激を 呈示し, 小文字に対応した大文字をマス目の中にイメ 一ジさせた．被験者は×印がイメージした大文字と重 なるかどうかについてできるだけ早く正確に選択反応 を行った. 重なる場合 (ON), 重ならない場合 ( $\mathrm{OFF}$ ), さらにその中で $\times$ 印の位置がアルファベットの描き 順の最初にある場合 (early), 最後にある場合 (late) は等確率であった. Cue が単純な文字の試行 (Simple), 複雑な試行 (Complex), 及び他の 2 文字を呈示する試 行は同数ずつであった. 48 試行を 1 ブロックとし, 各 条件 15 ブロックずつ行った. 刺激の呈示順は全てラン ダムであり, 反応手は被験者ごとにランダマイズした。 記録・分析 各被験者の反応時間の代表値としては中 央值を用いた.脳波は頭皮上 25 部位から両耳架の平均 電位を基準としてサンプリング周波数 $200 \mathrm{~Hz}$ で導出し た. 垂直眼球運動は左目上下から，水平眼球運動は左 右眼角から双極導出した。 $0.05-30 \mathrm{~Hz}$ のバンドパスフ イルタをかけ, Probe 刺激呈示前 $200 \mathrm{~ms}$ をベースライ ンとして $1200 \mathrm{~ms}$ 区間を加算平均した．行動指標につ いて複雑さ $($ Simple $/$ Complex $) \times$ 反応 $(\mathrm{ON} / \mathrm{OFF}) \times$ Probe 位置 (early/late) の分散分析を行った. 波形の分岐 はデータポイントごとの $\mathrm{t}$ 検定を行って評価した。

\section{結果と考察}

行動指標 反応時間では 3 要因の交互作用が有意であ った（Fig. 1)。ONにおいてはLateの場合に反応時間 が遅延し, 複雑さの効果は Late でEarly よりも大きか った。一方，OFF ではそのような効果は見られず，

Simpleよりも Complex で, また Early よりも Late で 反応時間が遅延したのみであった，もし生成完了後に 走査を行っているのであれば, Early においても複雑 さの効果が現れるはずである.このことから ONにおい ては心的イメージの生成と走査が同時に行われ，OFF では生成・走査が完了後, 再度走査が行われていたこ とが示された。

ERP Early とLate 波形の分岐を, Probe 位置による 脳活動の違いと捉え, 分析を行った (Fig. 2). 反応時 間から ON では生成及び走查, OFF では再走查の結果と して波形が異なると考えられる. 結果, ON ではSimple での分岐が観察されなかったが，Complex では潜時約 $250 \mathrm{~ms}$ 付近及び $500 \mathrm{~ms}$ 付近で分岐した. Complex では Probe が Early であった場合には，ON であることを認 識した時点で処理を中断したと考えられる.一方, OFF では $250 \mathrm{~ms}$ 付近での分岐はほぼ同時であったが， 500 $\mathrm{ms}$ 付近では Simple の方が Complex よりも早く分岐し た. 文字の複雑さによる生成時間の違いが持ち越され て走査時間の遅延を引き起こした可能性がある.また, 潜時約 $250 \mathrm{~ms}$ で左後部優勢に惹起された陰性電位に関 して, 電極 P07 での振幅を比較した (Fig. 3). 複雑さ $\times$ 反応 $\times$ Probe 位置の分散分析の結果, 反応之 Probe 位置の交互作用および複雑さの主効果が見られた。従 って, 視覚イメージの生成及び走査の過程が視覚に関 わる比較的初期の ERP 成分を変動させたことが示され た.
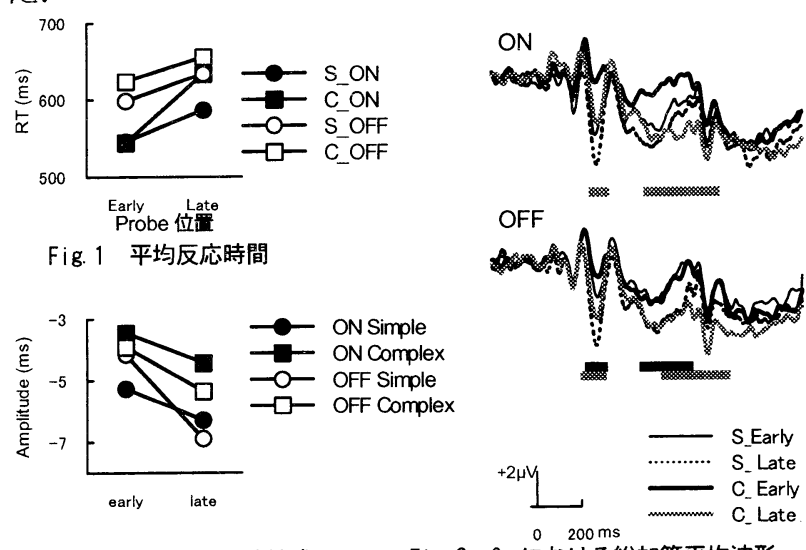

Fig. 3 P07 における陰性成分の $250 \mathrm{~ms}$ 付近における平均振幅
Fig. $20 z$ における総加算平均波形 黒の下線がSimple, 灰色が Complex で有意差があった区間. 
生 理 心 理

\section{映像視聴中の体性感覚 3 刺激才ドボール課題に おける事象関連電位}

○重光 ゆみ・入戸野 宏・堀 忠雄

(広島大学大学院総合科学研究科)

ヒトは，面白く興味を感じる対象に対して自発的に 向ける。面白い映像に対して, 退屈な映像よりも多く の注意が配分されることが，プローブ法を用いた研究 から示されている。プローブ法とは，注意資源の量が 一定であるという理論に基づいて，ひとつのことに向 いている注意の量を, 他の物理刺激(プローブ刺激に対 する反応を測定することによって間接的に評価する方 法である。面白い映像を見ているときは，残っている 注意量が少なく，プローブに対する反応は小さいが， 退屈な映像を見ているときは, 残っている注意量が多 く,プローブに対する反応が大きくなる(Suzuki et al., 2005)。

事象関連電位 (event-related potential: ERP)の P300 の振幅は, 注意資源の配分を反映する指標である。 本研究では, 視聴覚の複合的体験に対寸る注意の配分 量を測定するため, 感覚モダリティの異なる体性感覚 (振動)プローブを用いて， ERP を測定する。

\section{方 法}

実験参加者 右利きの大学生・大学院生(男性 5 名, 女 性 7 名，平均年齢 24.1( 22.1 )歳)が実験に参加した。

課題 振動モ一ターを用いて標準刺激(中指, $p=.70$ ), 標的刺激(小指, $p=.15$ ), 非標的刺激(母指, $p=.15$ ) をランダムな順序で指掌に呈示した(持続時間 $200 \mathrm{~ms}$ )。 コメディ映画から 2 つのシンを選出し, 動画のみ条 件では音声なしで, 動画十音声条件では音声ととも呈 示した。

手続き 最初に参加者は静止画を見ながら体性感覚 3 刺激オドボール課題を行った(静止画条件 1)。次に音声 なし映像を見ながら課題を行ってもらう動画のみ条件 と, 音声付映像を視聴しながら課題を行ってもらう動 画十音声条件を, 順序をカウンタバランスして実施し た。最後にもう一度, 静止画を見ながら課題を行った (静止画条件 2)。参加者には，標的刺激が呈示された時 に刺激呈示手と反対の手でボタンを押して反応するよ う求めた。刺激呈示手と反応手は参加者間でカウンタ バランスをとった。映像を呈示したブロックの後には, 映像の面白さを 9 件法で評定させた(1 退屈-9 面白い)。
記録·分析 脳波は国際 $10 \%$ 法に基づく頭皮上 32 部位 より鼻尖を基準として記録した。バンドパスフィルタ $0.05-100 \mathrm{~Hz}$ で増幅し，サンプリング周波数 $500 \mathrm{~Hz}$ で $\mathrm{A} / \mathrm{D}$ 変換した。条件・刺激・部位ごとに加算平均波形を 求めた。静止画条件 1 と 2 は, 加算平均して分析に用い た。加算平均区間は刺激呈示前 $200 \mathrm{~ms}$ から呈示後 1000 $\mathrm{ms}$ までとした。刺激呈示後 $350-600 \mathrm{~ms}$ に生じた最大 の陽性波をP300 として頂点潜時と振幅を測定した。

\section{結果亡考察}

面白さの平均評定値(士標準偏差) は，動画のみ条件で 6.8(土1.64)，動画十音声条件で $7.5( \pm 1.31)$ であり，動画 十音声条件のほうが有意に高かった $(p<.05)$ 。

標的刺激に対して頭頂部優位の P300(標的 P300)が, 非標的刺激に対して中心-頭頂部優位の P300(非標的 P300)が惹起された。非標的 P300 は標的 P300より有意 に潜時が短かった $(444 \mathrm{~ms}$ vs. $503 \mathrm{~ms}, p<.05)$ 。Figure 1 に $\mathrm{Cz}$ における $\mathrm{ERP}$ 総加算平均波形を示した。標的 $\mathrm{P} 300$ と非標的 P300 の振幅は, 静止画条件で小さくなった。 振幅の減衰は動画のみ条件より動画十音声条件のほうが 顕著であった。どちらの刺激に対する P300 振幅值も, 条件の主効果が有意であった $(p s<.05)$ 。標的 P300 振幅 は, 静止画条件より動画のみ条件と動画十音声条件で振 幅值が有意に減衰していた $(p s<.05)$ 。他方, 非標的 P300 は動画十音声条件で他の 2 条件より有意に減衰しており, さらに静止画条件より動画のみ条件で有意に減衰してい た $(p s<.05) 。 つ ま り ，$ 動画に音声を付加したことによる 条件差は，非標的 P300についてのみ有意になった。

結果より，振動刺激を用いた 3 刺激オドボール課題の 非標的刺激に対して惹起された P300 が，視聴覚体験の 注意配分量を反映する指標となることが示された。
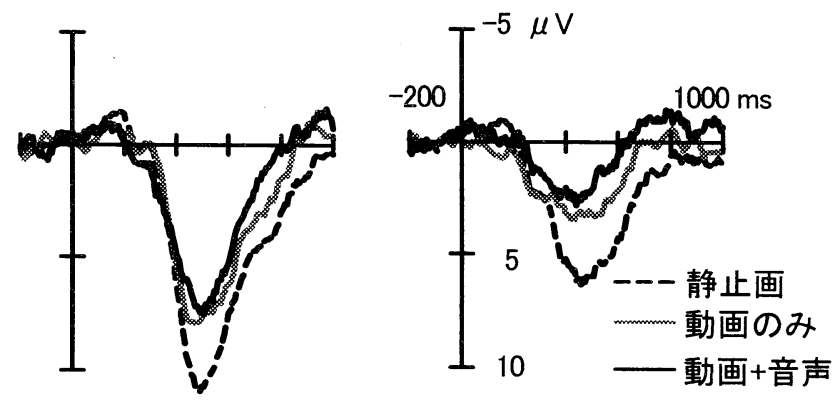

Figure 1. Cz におけるERP 総加算平均波形 $(N=12)$

\section{引用文献}

Suzuki, J., Nittono, H., \& Hori, T. (2005). Level of interest in video clips modulates event-related potentials to auditory probes. International Journal of Psychophysiology, 55, 35-43. 
感情状態が初期視覚過程における空間的注意の 範囲に及ぼす影響

○守谷 大樹·河西 哲子.室橋 春光

(北海道大学大学院教育学研究科)

\section{1. 目的}

感情が初期視鸴過程における空間的注意の範囲に関連 するトップダウンバイアスを生じさせる可能性が示唆 されている。しかし，それが情報処理のどの段階で起 こる注意選択に影響するかは明らかにされていない。 本研究では, 感情状態が初期の視覚過程における空間 的注意の範囲に与える影響について，事象関連電位を 用いて検討した。

\section{2. 方法}

【被験者】裸眼もしくは矯正で正常視力の大学生・大 学院生 12 名（女性 7 名, 男性 5 名, 平均 22.8 歳）。

【刺激・手続き】感情誘引刺激は複数の映画から数分 間のシーンを, 否定的 $(\mathrm{Ne})$, 中性 $(\mathrm{Nu})$, 肯定的 $(\mathrm{Ps})$ 感情条件毎にそれぞれ 2 つずつ選び出し用いた。1つ の感情条件は 2 ブロックで構成された。感情誘引は毎 ブロック，実験課題開始直前に行った．実験課題はフ ランカー課題で, 課題刺激は一致 $(\langle\langle\langle\langle, \gg \gg\rangle)$ と 不一致 $(\gg\rangle\langle\rangle,\langle\langle\rangle\langle\langle)$ から構成された。課題中, プ ローブとしてアスタリスク (*) が呈示された。プロー ブの呈示位置は左一遠（中心から左に $3.1^{\circ}$ ）, 左一 近（同 $1.55^{\circ}$ ), 右一近（中心から右に $1.55^{\circ}$ ）， 右一遠（同 $3.1^{\circ}$ ）の 4 籄所だった。それぞれの位置 が課題刺激のディストラクタの位置に対応寸るように 呈示した（課題刺激とプローブの呈示順はランダム, 呈示頻度は 1:2)。刺激の呈示時間は課題刺激が $200 \mathrm{ms,}$ プローブが $50 \mathrm{~ms}$ で，刺激間間隔は課題刺激後が 1000

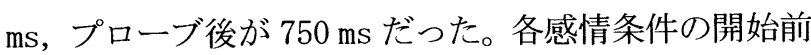
と終了後に，一般感情尺度（小川ら，2001）による感 情評価を行った。

【記録及び処理】課題刺激に対する RT 及び誤答率は刺 激後 200-800 ms 以内の反応について, 刺激の一致性, 感情条件毎に算出した。EEG は国際 10-20 法に基づく 頭皮上 25 筒所から，鼻尖を基準として，サンプリング 周波数 $200 \mathrm{~Hz}$ ，バンドパス $0.3 \sim 30 \mathrm{~Hz}$ ，電極間抵抗 $10 \mathrm{k} \Omega$ 未満で記録した。HEOG は左眼窩下と Fp 1 から, VEOG は両眼窩外から双極導出して記録，モニタした。 プローブに対する ERP は, 感情条件と呈示位置每に誤
反応及び $\pm 80 \mu \mathrm{V}$ 以上の振幅を含まない試行を加算平 均して算出した。刺激前 $200 \mathrm{~ms}$ の区間を基準にベース ライン補正した。

\section{3. 結果・考察}

【感情評価】各感情条件において，それぞれの感情状 態を反映する項目の得点が条件後に有意に増大，又は 低下した。このことは，標的とした感情状態を操作で きたことを示す。

【行動遂行】課題刺激に対する RT，誤答率は一致刺激 よりも不一致刺激で遅延，増大した。感情による影響 はなかった。

【プローブに対する ERP】後頭側頭部（T5，P07，T6， P08）の，P1 潜時帯（80-130ms）と N1 潜時帯（150$190 \mathrm{~ms}$ ）平均振幅に対し，感情（3）×距離（2）×視 野（2）×半球（2）×電極（2）の ANOVA を行った。 P1 潜時帯では, Ne 条件で遠位置と近位置の刺激に対す る振幅の差がなかった。Ps 条件と $\mathrm{Nu}$ 条件では, 刺激 呈示位置が近位置の時に，遠位置に呈示された時より も振幅が大きかった。P1 振幅は，空間的注意が覆って いる範囲に出現した刺激に対して増大寸る。従って, Ps 及び $\mathrm{Nu}$ 条件では空間的注意の範囲が視野の中心近 くに集中し，それに対して $\mathrm{Ne}$ 条件では空間的注意の範 囲が，視野の中心から離れた位置まで覆っていたと考 えられる。一方 $\mathrm{N} 1$ 潜時帯では, $\mathrm{Ne}$ 条件と $\mathrm{Nu}$ 条件で遠 位置と近位置の差がなかったが, Ps 条件では遠位置の 時に，近位置の時よりも振幅が増大した。これは，P1 における距離の効果が $\mathrm{N} 1$ 潜時帯に重なったものだろ う。以上の結果は，感情状態が初期視覚過程における 空間的注意の焦点化にトップダウンバイアスを生じさ せることを示唆する。

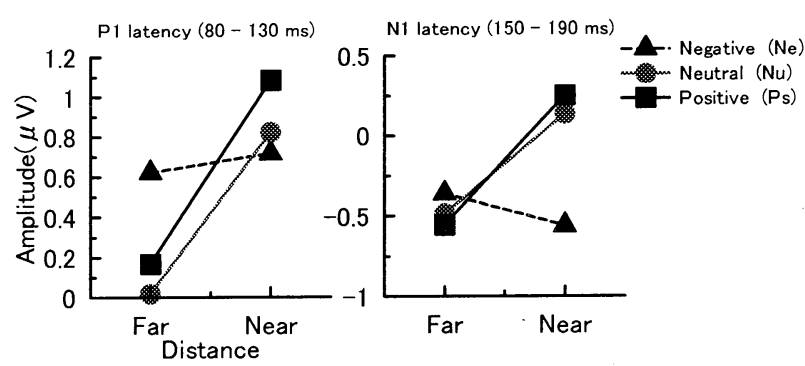

図 1. 感情条件と距離毎のプローブに対するP1 潜時 帯（左）と N1 潜時帯（右）における平均振幅 
生 理 心 理

\section{感情喚起スライドの注視か聴覚刺激に対する 事象関連電位に及ぼす影響 \\ $\bigcirc$ 杉本 紗耶加・ 入戸野 宏・堀 忠雄 (広島大学大学院倊合科学研究科)}

ひとは気分が良いときには細かなことは気にならな いが，苛立っているときや不安なときには小さな物音 にも過敏に反応してしまう。このように感情状態によ って外界の刺激に対寸る処理は異なると考えられる。 刺激に対する情報処理過程を反映する事象関連電位 (event-related potential：ERP)を測定することにより， 感情状態による情報処理の変化が検討されてきた。

Cuthbert et al. (1998)は, 感情喚起スライド注視中 の実験参加者に驚愕音を呈示し，ERP を測定した。そ の結果, 不快スライド注視中に潜時約 $100 \mathrm{~ms}$ で生じ る陰性波 N1 の振幅が減衰した。このような N1 振幅 の変化は驚愕音に対してのみ認められ, 純音に対する ERPには認められなかった。さらに驚愕音に対しても， 音を無視するよう教示したときには認められなかった と彼らは報告している。

また, Mercado et al. (2006)において, 状態不安の高 い人，純音に対して潜時約 $200 \mathrm{~ms}$ に生じる陽性波 P2 の振幅が不快スライド注視中に増大寸ることが報 告されている。このことから P2 振幅にスライドよって 喚起された感情状態が反映される可能性が示唆された。

さらに Surakka et al. (1998)は, 快スライド注視中 に, 逸脱音に対して潜時約 $100-200 \mathrm{~ms}$ に生じるミス マッチ陰性電位(mismatch negativity: MMN)の振幅 が減衰したと報告している。

本研究では，スライドによって喚起された感情状態 が聴覚刺激に対する ERPに及ぼす影響について, 3 種 類の純音を用いて検討した。

\section{方法}

実験参加者 13 名 (男性 5 名・女性 8 名: 平均 22.8 歳) 視覚刺激 感情喚起スライド(International Affective Picture System; Lang et al., 1999)より, 標準評定值に 基づいて, 快・中性・不快スライドを各 40 枚選定した。 聴覚刺激 高逸脱音 $(2000 \mathrm{~Hz}, p=.08) \cdot$ 低逸脱音(1050 $\mathrm{Hz}, p=.08)$ ・標準音 $(1000 \mathrm{~Hz}, p=.84)$ をスライド注視 中の参加者に対してヘッドフォンから呈示した(刺激 オンセット間間隔 $600 \pm 50 \mathrm{~ms}, 60 \mathrm{~dB} / \mathrm{SPL})$ 。
手続き 実験は 3 ブロック行った。1 ブロックにつき， 快・中性・不快スライドが各 $13 \sim 14$ 枚含まれた計 40 枚 のスライドを，1枚ずつランダムに呈示した。各スライ ドの呈示時間は 16 秒間で，スライド呈示 1 秒後から音 刺激の呈示を開始した。音刺激は無視するよう教示した。 各スライド呈示終了ごとに，スライドの感情価・覚醒度 について9件法で評定を行ってもらった。

ERP 測定 頭皮上 32 部位より鼻尖を基淮として, サンプ リング周波数 $500 \mathrm{~Hz}$ で記録した。1-30 Hz のデジタルフ イルタをかけた後, 刺激呈示前 $100 \mathrm{~ms}$ から後 $500 \mathrm{~ms}$ の 区間を加算平均した。MMN 振幅は，高逸脱音・低冕脱 音に対する ERP波形から，標準音に対する ERP 波形を 引いた引算波形上で 100-200 ms の区間平均電位として 算出した。

\section{結 果・考察}

主観指標 参加者によるスライドの平均評定值は感情価 が快(6.7) > 中性 $(5.0)>$ 不快(3.1)，覚醒度が快(4.7) ・ 不快 (4.8)> 中性(3.0)となり, 選出したスライドの妥当性が確 認された。

ERP Figure 1にERP 波形を示した。潜時約 $100 \mathrm{~ms}$ に N1 が生じ，高冕脱音に対するN1 は不快スライド注視中 に増大した $(p<.01)$ 。また, 高逸脱音に対しては潜時約 $210 \mathrm{~ms}$, 標準音に対しては潜時約 $170 \mathrm{~ms}$ に 2 が生じ た。P2は快スライド注視中に減衰がみられた $(p<.01)$ 。 高逸脱音・低冕脱音に対して生じた $M M N$ には，スライ ドの条件による有意な効果は認められなかった。

Cuthbert et al. (1998)が示した不快スライド注視中の $\mathrm{N} 1$ 振幅の増大が，驚㗁音を使わず，音刺激を無視した本 実験においても確認された。また状態不安の高低に関わ らず，感情状態が P2 振幅に反映されることが示された。 MMN 振幅にはSurakka et al. (1998)によって示された ような快スライド注視中の有意な減衰が認められなかっ た。音刺激の属性や感情喚起法のわずかな違いが研究結 果に影響する可能性が示された。

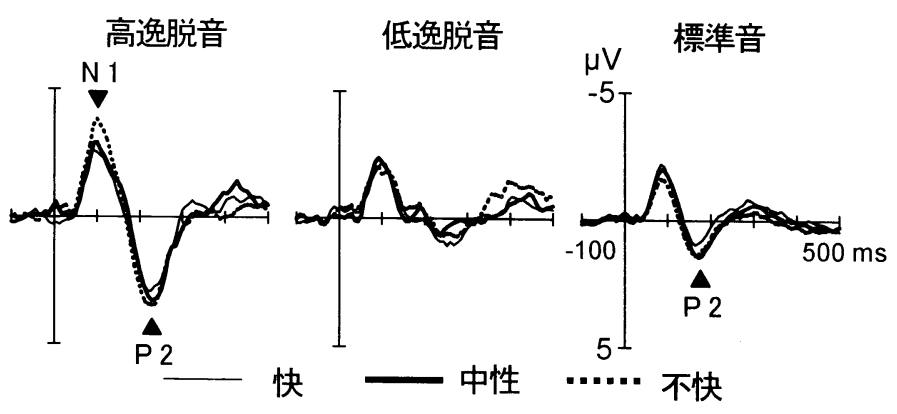

Figure 1. スライド注視中に呈示される音刺激に対する $\mathrm{ERP}$ 総加算平均波形 $(N=13, \mathrm{Cz}$ 記録 $)$ 
感情価がワーキングメモリ課題中の睬内活動

\section{に及ほす影警}

一NIRSを用いた検討一

○渡辺早紀（東海女子大学心理学科）

柏野牧夫（NTTコミュニケーション科学基 整研究所 - 科学技術振興機構 ERAT0下條潜在脳機能 プロジェクト)

野村 理朗 (束海女子大学心理学科)

Go/NoGo 課題におけるNogo 反心時の前頭 前野腹外側部, 特に右側での活動が活発にな ることが f MRI やPETを用いた神経イメージ ング研究に拈いて報告されている(e.g. , Horn, 2003)。Go/NoGo 課題江、刺激表象の保 持と操作を要する課題として広く知られてい るが、とくに刺激の感情価がポジティブであ る場合には、前頭前野背外側部が活発化する のに対して，感情価がネガティブである場合 には同領域の活動が低下することが報告され ている（William et a1., 2002)。本研究で は, この Go/NoGo 課題における視覚刺激の感 情価を操作し, 課題遂行中の脳血流量を NIRSにより計測することにより，行動指標 の結果と併せて、感情価がワーキングメモリ 課題中の脳内活動に及ぼす影響について総合 的に検討与る。

$$
\text { 方 法 }
$$

右利きの女子大学生 23 人(平均午齢 20.6 \pm 1.4 歳)に対し, 多チャンネル NIRS(浜松ホ トニクス社製，NIR0-200）を用いて中枢神経 活動を観測した。装着部位は両耳上を $4 \mathrm{ch}$ (左), $8 \mathrm{ch}$ (右)と定め, 課題遂行中の酸化 へモグロビン $(\mathrm{oxy}-\mathrm{Hb})$ と脱酸化へモグロビン (deoxy-Hb) の変化量を計測した。本実験で用 いた Go/NoGo 課題は, 本試行前にコンピュー タ・ディスプレイ上に提示された 10 枚の 3 カテゴリーの感情（快, 不快, 中性）を喚起 させる刺激画像を記憶し，課題において $800 \mathrm{~ms}$ 呈示された画像が, 記憶した画像との
同異判断を早く，正確に反応キ一押させるも のであった。画像刺激の Pleasant 条件, Unpleasant 条件, Neutral 条件の 3 条件の 各々について 80 試行を行った。

\section{結 果}

全条件内での各チャンネル $\mathrm{axy}-\mathrm{Hb}$, deoxy-Hb の増加量と行動指標（RT，CFR, OER）についての相関分析を行つた結果, Pleasant 条件での比率 2:8の $7 \mathrm{ch}$ の oxy-Hb 増加量と RT 間に負の相関 $(r=-0.405$, $p<.10)$, Unpleasant 条件での比率 $2: 8$ の, $5 \mathrm{ch} \quad(r=0.581, p<.01), 6 \mathrm{ch} \quad(r=0.374$, $p<.10), 7 \mathrm{ch} \quad(r=0.488, \quad p<.05), 8 \mathrm{ch}$ $(r=0.529, \quad p<.01)$ の deoxy-Hb 増加量と RT 間に正の相関, 比率 $8: 2$ の, 8ch の deoxy-Hb 增加量と RT 間に正の相関 $(r=0.535$, $p<.01)$, 比率 $8: 2$ の, $3 \mathrm{ch} \quad(r=-0.415$, $p<.05), 5 \mathrm{ch}(r=-0.430, p<.05), 7 \mathrm{ch} \quad(r=-$ $0.360, p<.10), 8 \mathrm{ch}(r=-0.560, p<.01)$ の oxy-Hb 増加量とRT間に負の相関がみられた。 相関が見られたのは主に, 比率 $2: 8$ であり, 測定部位も $\mathrm{oxy}-\mathrm{Hb}$, deoxy-Hb ともに, 頭部 の右側に集中していた（㥵関図）。

\section{考察}

NIRS 計測により、Nogo 反态時の右腹外側 前頚前野の活動が確認されるとともに，右背 外側前頭前野にあたる $7 \mathrm{ch}$ から観測された神 経活動が，ポジティブ条件では六進し，ネガ ティブ条件で抑制されることがわかった。今 後は、ワーキングメモリ一課題時の右前頭前 野における調整機能，ならびに腹外側前頭前 野の反応抑制機能の両者の関係性についての 検討を実施する予定である。

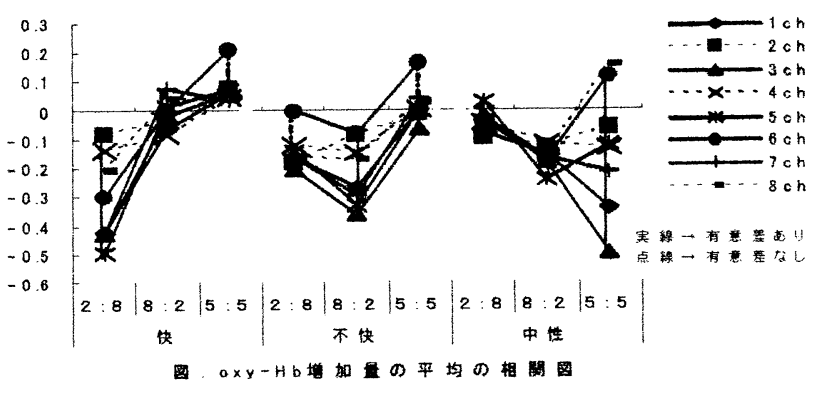


感情喚起刺激の呈示方法が主観的評価と心拍数に 及ぼす影響

○本多 麻子 (川村学園女子大学文学部)

山崎 勝男 (早稲田大学スポーツ科学学術院)

\section{目的}

感情には文脈依存の性質があると指摘されてきた。 たとえば闘争か逃走の場面における恐怖の場合, 闘争, 逃走あるいは凍結に伴う恐怖であるのかを区別する必 要がある。その理由は, 体性系や心蔵血管系の活動が 異なるからである。本研究では, 感情喚起の文脈を操 作した刺激の呈示方法が主観的評価と心拍数 (HR) に及ぼす影響を検討した。同一の感情価の刺激を連続 的に呈示する場合と, ランダムな順番で呈示する場合 を設定することによって,感情喚起の文脈を操作した。 方法

参加者: 大学生と大学院生 24 名 (平均 $23.6 \pm 1.9$ 歳) で あった。参加者を block 群と random 群に割り当てた。 実験刺激 : 感情喚起刺激 LAPS (Lang et al., 1999) から, 快・中性・不快刺激を各 6 枚ずつ選択した。block 群で は同一の感情価の刺激を連続的に呈示し, random 群で は刺激をランダムな順番で呈示した。刺激呈示時間は, block 群では $50 \mathrm{~s}$, random 群では $30 \mathrm{~s}$ であった。 質問紙: 刺激呈示終了毎に, 感情状態 (楽しみ, 満足, 幸福, 怒り, 悲しみ, 恐怖, 嫌悪, 不安) の程度を VAS (visual analog scale) によって評定させた。また，SAM (self-assessment manikin) によって感情価, 覚醒, 支配 性をそれぞれ9段階で評定させた。

記録方法 : 心電図 (ECG) は T. C. 0.01 s, H. C. $100 \mathrm{~Hz}$ で導出し，磁気記録後，オフライン処理に供した。 手続き: 電極装着後, 実験の概要や質問紙の記入方法 などを教示した。6枚の刺激呈示毎に 3 min 休欯した。 分析方法: 群と感情価に基づいて分析した。VASは最 小值から参加者のプロット位置までを $\mathrm{mm}$ 単位で計測 し, 評定値とした (最大值 10)。VAS と SAM の項目毎 の評定值について，それぞれ群 (2) ×感情価 (3) の2 要因分散分析を行った。ECGについて，サンプリング データから $1 \mathrm{~s}$ 毎の平均 $\mathrm{HR}$ を求めた後, 標準化を行 い, $1 \mathrm{~s}$ 毎の標準得点を算出した。刺激呈示時点から $25 \mathrm{~s}$ 間を $5 \mathrm{~s}$ 毎の 5 区間 (interval) に分けた後, 各区間 の平均 HR (z-score) を求めた。HRについて, 群 (2) × 感情価 (3) × 区間 (5) の 3 要因分散分析を行った。
結果

質問紙について, 全項目の感情価要因の主効果が認 められ, 標的感情が喚起された $(p<.01)$ 。群要因の主 効果は不安で認められ, block 群と比較して, random 群の不安が高かった $(p<.05)$ 。恐怖と嫌悪はそれぞれ 交互作用が有意であった $(p<.05)$ 。 block 群と比較して， 不快刺激に対する random 群の恐怖と嫌悪は高かった。 刺激呈示中の HR 推移を Figure 1 に示した。分散分析 の結果, 群 $\times$ 感情価と, 感情価 $\times$ 区間の交互作用がそ れぞれ認められた $(p<.05)$ 。 block 群と比較して, 不快 刺激呈示中の random 群の HR 推移は低かった。感情価 に関わらず,刺激呈示から $5 \mathrm{~s}$ 以降に HR が低下した。

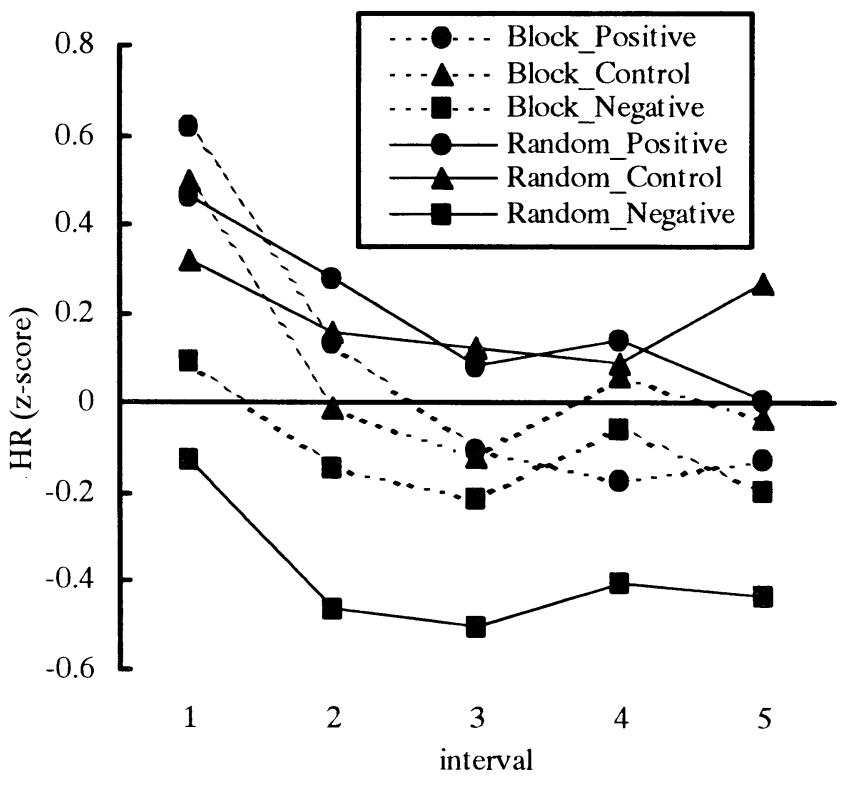

Figure 1 Change in HR (z-score) after stimulus onset.

\section{考察}

感情喚起の文脈を操作した刺激の呈示方法は，不快 刺激に対する主観的評価と HR に影響を及ぼした。 block 群と比較して random 群では，不快刺激に対する 恐怖と嫌悪の評定值が高く, 不快刺激呈示中の HR は 低い水準で推移した。IAPS の不快刺激に対する HR の 低下は, 注意資源の増加に起因する定位反応の増大で あると報告されてきた。Defense cascade model (Lang et al., 1997) は，受動的注意による定位反応から，行動の 遂行を伴う防衛反応に至る段階において，覚醒水準と 生理反応の出現様相を対応づけたものである。このモ デルを考慮すると, 本研究の random 群でみられた不 快刺激に対する HR の定位反応の増大は, より適応的 な反応である可能性が考えられる。 
Go/NoGo 課題と Stop/NoStop 課題における事象関連脳電位 : 不快束激の提示が予想される事態のNOGo 電位とStop 電位の 比較

○赤嶺 亜紀 (愛知学院大学大学院心身科学研究科) 木田 光郎 （愛知学院大学心身科学部）

画像の弁別反応課題, Go/NoGo 課題や Stop/NoStop 課題の反応しない刺激, NoGo 刺激と Stop 刺激に対し てP3の 2 つの下位成分が生じた (赤嶺・木田, 2004)。 刺激後 $300 \mathrm{~ms}$ 近傍の, Pz 優勢な初期 P3 の振幅は課題 間に差がなかったが, 刺激後 $500 \mathrm{~ms}$ 近傍の, Cz から Pz に分布する後期 P3 は Stop 刺激に対して顕しく増大し た。また Stop 刺激の後期 P3 は初期 P3 より増大した。

ヒトの情報処理機構には刺激処理系と反応処理系の 2 つが並列すると想定されるが，課題を効率よく遂行 するためには，標的刺激の速やかな処理だけでなく， 非標的刺激の処理を抑制することも重要である。通常 の弁別反応課題, Go/NoGo 課題の非標的·NoGo 刺激も刺 激処理系を始動させる。しかし NoGo 刺激の場合, 比較 的初期に標的テンプレートとのずれが生じるため, 情 報処理機構の賦活は Go 刺激の場合ほど強くない。した がって NoGo 刺激の処理は強い抑制を必要としないで 終結すると考えられる。一方, Stop/NoStop 課題は, 例えば，自動車刺激にはボタンを押さない(Stop)，そ れ以外の刺激全てに反応する (NoStop) よう求める弁別 反応課題である。この場合, 自動車, Stop 刺激は課題 の手がかりであり, 被験者の注意捕捉 (attention capturing)刺激である。Stop 刺激は情報処理機構を強 く賦活するが，被験者はこの刺激にボタンを押しては ならないため, 処理機構のはたらきを抑制し，運動反 応を制止しなければならない。したがって Stop 刺激の 後期 P3 増大は, 賦活された反応処理系の積極的な抑制 を反映するものと考えられた。

本研究では情動刺激を用いた Go/NoGo 課題の NoGo 刺激と Stop/NoStop 課題のStop 刺激(いずれも通常の 自動車画像）に対する ERP を記録し，2 種の課題の処
理過程を再検討した。

【方法】被験者: 学生 31 名。刺激: 人物中性, 人物不快, 自動車, 電化製品, 花, 風景のカラー画像 が無作為順に, 被験者の前方 $1 \mathrm{~m}$ のディスプレイに $500 \mathrm{~ms}$ 提示された。刺激の提示比は, Go/NoGo 課題では 人物中性: 人物不快: 自動車: 電化製品: 花: 風景 $=2$ : $2: 3: 1: 1: 1$, Go 刺激 : NoGo 刺激=4:6 であった。 一方, Stop/NoStop 課題では人物中性: 人物不快: 自 動車: 電化製品: 花: 風景=1.5:1.5:4:1:1:1, Stop 刺激 : NoStop 刺激=4:6 であった。課題 : Go/NoGo 課題は人物中性および不快刺激に対するボタン押し (Go) 課題であり, Stop/NoStop 課題は自動車刺激に反 応しない(Stop), 自動車以外の刺激全てにボタンを押 す(NoStop)課題であった。手続き：全ての被験者が 各課題を 300 試行ずつ行った。実験は 2 日にわけて行 われ，1日にいずれか一方の課題が実施された。

【結果と考察】誤反応数 : いずれの被験者も誤反応 は少なかったが, NoGo 刺激 (90 試行中 0.8 回, SD=1.1) より Stop 刺激（120 試行中 6.3 回， $\mathrm{SD}=4.4 ）$ に対する 誤りが多かった。 ERP：NoGo 刺激と Stop 刺激に対し て初期 P3 と後期 P3 が生起した。これらの電位の出現 タイミングや頭皮上分布, 課題間の振幅の大小の関傜 は先行研究と同様であった (Table. 参照)。NoGo 電位 やStop 電位には不快刺激の提示の影響は認められな かったが, Stop 刺激に対する反応処理系の積極的な抑 制が再び示唆された。Stop 刺激の後期 P3 の著しい増 大は反応抑制に投入された処理資源の多さを表わすも のと推察されるが, Stop 刺激に対して誤反応が多いこ とから，一旦賦活された処理機構の抑制は容易ではな いことが示唆された。これまでのところ後期 P3 は反応 処理の抑制を反映するものと考えられるが，反応準備 状態の打ち消しに関わるのか, 運動反応出力の制止に 関わるのか，その心理的機能は十分明らかでない。こ れまでの実験では Go 刺激や NoStop 刺激に対して運動 反応を求めているが, mental count を求めた場合など, 反応様式の影響を観察することが必要と思われる。

Table. NoGo刺激とStop刺激に対するP3. 全被験者の平均(上段)とSD(下段).

\begin{tabular}{cccccccc}
\hline & \multicolumn{3}{c}{ NoGo刺激 } & \multicolumn{3}{c}{ Stop刺激 } \\
\cline { 3 - 7 } & $\mathrm{Fz}$ & $\mathrm{Cz}$ & $\mathrm{Pz}$ & $\mathrm{Fz}$ & $\mathrm{Cz}$ & $\mathrm{Pz}$ \\
\hline 初期P3 & $290-340 \mathrm{~ms}$ 区間の平均電位 & -0.92 & 4.13 & 7.48 & 0.03 & 3.85 & 8.42 \\
& $(4.05)$ & $(5.80)$ & $(4.31)$ & $(3.85)$ & $(5.45)$ & $(3.99)$ \\
& & 2.94 & 5.30 & 6.82 & 8.31 & 14.49 & 14.25 \\
後期P3 & $460-510 \mathrm{~ms}$ 区間の平均電位 & $(3.73)$ & $(4.80)$ & $(4.38)$ & $(5.37)$ & $(7.53)$ & $(6.11)$ \\
\hline
\end{tabular}




\section{情動予期に関する脳機能:MEG 及び fMRIによる検討}

○小野田慶一 (広島大学大学院医歯薬学総合研究科)

岡本 泰昌 (広島大学大学院医歯薬学総合研究科)

\section{【目的】}

不快な事象の予期は，嫌悪的な結果に対する準備や 防止のために，行動的及び生理的な修正を導き適応一 つながる. 本研究では，MEG 及びfMRI を用いて不快事 象の予期における神経生理学的な基盤と予期が実際の 不快事象の処理に与える影響に関して検討した。

\section{【MEGによる検討】}

予告刺激 $(\mathrm{S} 1)$ と警告刺激 $(\mathrm{S} 2)$ を対呈示する実験を行 った。 S1 には幾何学図形を，S2 には IAPS (international affective picture system)から選抜した 画像を用いた．S1 が S2 の情動価の情報を含む予期可 能条件, S1 が S2 の情動価の情報を含まない予期不可 能条件, $\mathrm{S} 1$ なしで $\mathrm{S} 2$ が提示される予告なし条件を設 定した。このような実験において，S1-S2 間隔におけ る随伴性磁気変動 (contingent negative variation: CMV)は，不快事象の予期，快事象の予期，どちらが 呈示されるか分からない時で異なるかを検討した。ま た，S2 に対する視覚誘発磁界(visual evoked field:

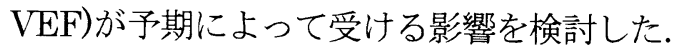

$\mathrm{S} 1-\mathrm{S} 2$ 間隔において前頭中心部の総加算平均波形を みると, S1 が呈示される条件ではすべて緩やかな磁気 変動(CMV)が観察されたが，その振幅に情動価の影響 を認められなかった。

$\mathrm{S} 2$ に対する後頭領域の総加算平均波形より, 全ての 条件で潜時 $120 \mathrm{~ms}$ にピークを持つVEF が認められた. 予期可能-不快条件における VEF 振幅は，予期可能快条件及び予期不可能-不快条件よりも小さくなって いた.

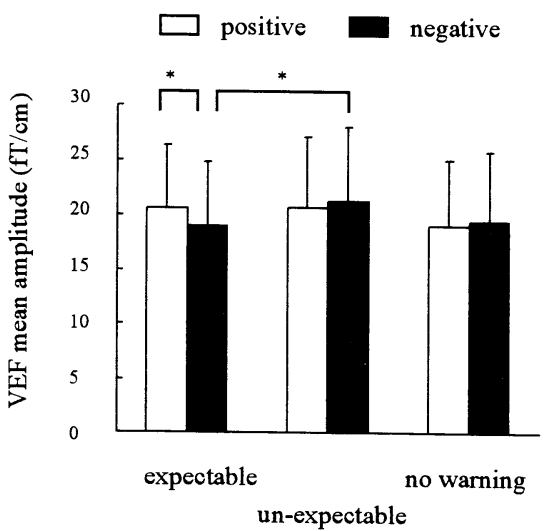

$\mathrm{VEF}$ の平均振幅
この結果は，不快事象の予期により，実際の不快事 象に対する視覚処理が抑制されていることを示す。

\section{【fMRIによる検討】}

MEG 実験と同様に，S1 と S2 を対呈示する実験を 行った. S1 に持続時間 4s の純音を，S2 には快・不快 の情動画像を用いた. $\mathrm{S} 1$ 終了と同時に $\mathrm{S} 2$ が 2 秒間呈 示された. S1 が高音の場合，S2 には必ず不快画像が 呈示され(Negative 条件)，S1 が低音の場合，S2には 必ず快画像が提示された(Positive 条件)。両条件はラ ンダムに提示された. SPM5により解析を行い，FDR corrected $\mathrm{p}<0.005$ を有意な賦活の基準とした。

予期区間 (S1) において Positive 条件よりも Negative 条件で活動が大きかった領域は, 背外側前頭 前野 (R, $x=28 y=54 \mathrm{z}=22)$ ，被殸 (L, -20012$)$ ，島 (L, -34-10 18), 中心前回 (LR, $42-8$ 56) であった. Negative 条件よりも Positive 条件で活動が大きかっ た領域は，背外側前頭前野(左，-32 26 46)であった. これらの結果から，情動事象の予期では，その予期さ れる事象の感情価によって左右差が存在し, 前頭葉, 線条体，島などの神経ネットワークが関与寸ることが 示された.

知覚区間 (S2)において Positive 条件よりも Negative 条件で活動が大きかった領域は，帯状回 $(-12$ -38 48)，島(R, 3026 4)であった. Negative 条件よ りも Positive 条件で有意に活動が大きかった領域は なかった. ROI 解析では有意な差はみられなかったが 一次視覚野における信号変化の時系列を比較したとこ ろ, Positive 条件よりも Negative 条件の方がピーク の立ち上がりが有意に早くなっていた。予期に関与す るネットワークからの制御により視覚野が影響を受け る可能性が示唆される.

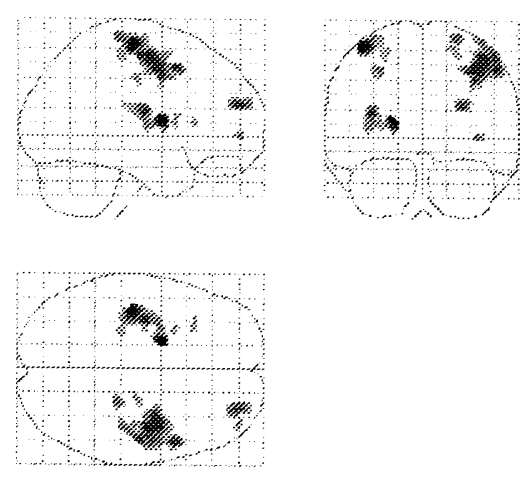

予期区間における Negative $>$ Positive 条件の領域 
確率学習における脳・自律神経系・内分泌系・免疫系 の機能的関連

○大平 英樹 (名古屋大学大学院環境学研究科) 市川 奈穂 (名古屋大学大学院環境学研究科)

磯和 勅子 (三重県立看護大学看護学部)

野村 理朗 (東海女子大学人間関係学部)

木村 健太 (名古屋大学大学院環境学研究科)

金山 範明 (名古屋大学大学院環境学研究科)

\section{目 的}

報酬を伴う学習事態において，脳の線条体や前頭前 野の内側部，眼窩部が関与することが知られている。 一方, 前頭前野の内側部, 眼窩部は, 視床下部や中脳 水道灰白質などにも直接的な神経投射を持つことから， 学習に伴い身体的反応が惹起されることが推測される。 また, ソマティック・マーカー仮説が提唱するように, 䒩起した末梢の身体的反応は脳にフィードバックされ， 爾後の情報処理や意思決定に影響を与える可能性も考 えられる。このような学習に伴う脳と身体の機能的関 連を探索するため, 随伴性を操作した典型的なオぺラ ント型の確率学習課題遂行時における, PET による脳 血流観測と, 各種生理的反応の同時記録を行った。

\section{方 法}

被験者：健常な男子大学生・大学院生 10 名。 課題と実験デザイン：無意味な線画図形が 2 同時に 提示され， $500 \mathrm{~ms}$ 以内に一方を選択することが求めら れた。70\%強化条件では，一方の図形は70\%, 他方の 図形は 30\%の確率で 100 円の金銭的報酬が与えられた。

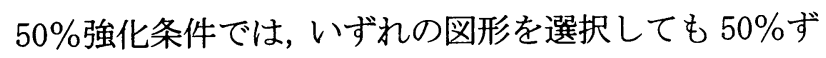
つの確率で同額の報酬が与えられた。各条件は被験者 内で操作され，40 試行を 4 分の 1 ブロックとし, 11 分の休憩を挟んで 3 ブロックずつ合計 120 試行が連続 して行われた。70\%強化条件と $50 \%$ 強化条件の順序は 被験者間でカウンタ・バランスされた。また，コンピ ユータが選択する側を指示する統制条件が各条件の開 始前に 2 ブロック配置された。

PET データの獲得と解析：局所脳血流量（rCBF）が PET により計測された。被験者は，各ブロックにおい て $370 \mathrm{MBq}$ の ${ }^{15} 0$ 水を静注された。画像は $2 \mathrm{~mm}$ x $2 \mathrm{~mm}$ の空間解像度で 32 枚取得された。

生理的指標 : 心臟血管系: 心拍 (ECG), 血圧, 心拍変 動性。免疫系: CD3+ T 細胞, CD3+CD4+ ヘルパーT
細胞, CD3+CD8+細胞障害性 $\mathrm{T}$ 細胞, CD3+CD19+ B 細胞, CD16+CD56+ NK 細胞。生理的指標は, 各ブロ ックにおける後-前の変化量が, PET 画像の相関解析 に用いられた。

\section{結果と考察}

行動：いずれの条件においても，多くの被験者では典 型的なマッチング則に基づいた選択行動が獲得され, 2 つ図形の選択確率は，70\%強化条件では 7：3, 50\%強化条件では5：5に分化した。

PET 差分画像: $70 \%$ 強化条件-統制条件の差分，50\%強 化条件-統制条件の差分の両方で, 内側前頭前野, 前部 帯状皮質背側部 (BA32，24）が共通に賦活した。この部 位は課題遂行のモニタリングやエラーの検出に関わる と推測される。50\%強化条件では, 眼窩野内側部 (BA10, 11）に顕著な賦活が生じたのに対し，70\%強化条件で は左外側前頭前野 (BA10，47）に賦活が生じた（Figure 1)。眼窩野はドーパミン神経の投射が密であり教化学 習に基づく学習の獲得に, 外側前頭前野は獲得された ルールの表象と維持に, 関与していると考えられる。 PET 相関画像 : 両条件とも, 心拍, NK 細胞比率の変化 量が, 前部帯状皮質, 眼窩野, 基底核群などの賦活と 有意な相関を示したが, その度合いは $50 \%$ 強化条件で より顕著であった。学習が困難な場合や学習が長く維 持される場合では，脳と身体の関連性がより強められ る可能性が推測される。

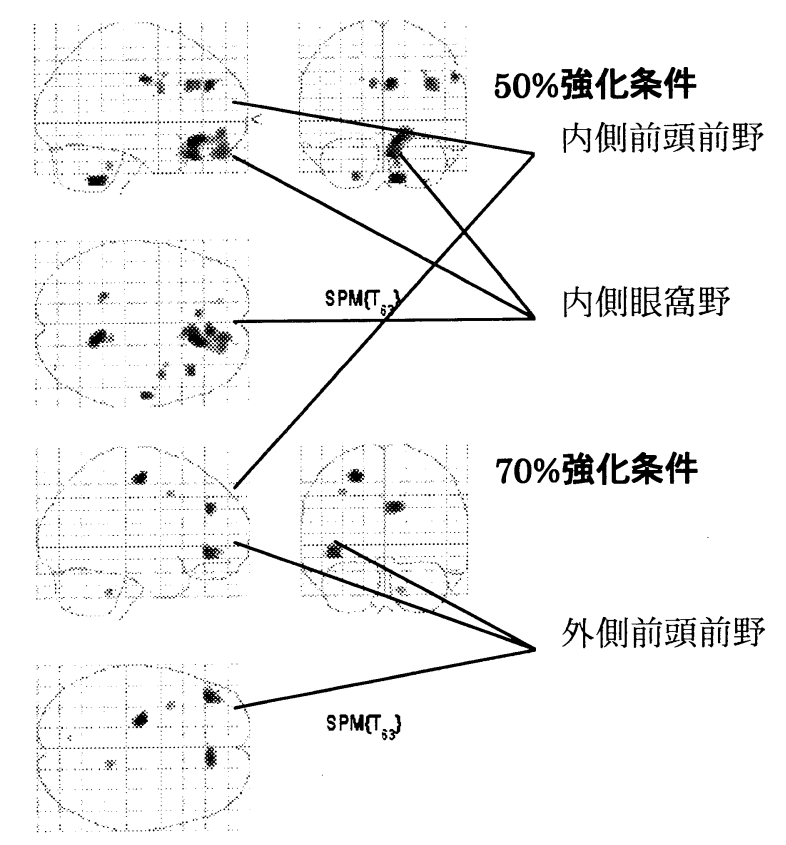

Figure 1. PET 差分解析の結果（ $\mathrm{p}<.001$, uncorrected $)$ 


\section{道応的・不道応的な自己注目が琶知・感情に与 える影零}

○村上裕樹 (名古屋大学大学院骤境学研究科)

大平 英樹 (名古屋大学大学院環境学研究科)

\section{【目的】}

Ingram（1990)は抑うつなどさまざまな感情障 害と自己注目傾向が相関することを明らかにし ている。同様に, Wells (1985)は自己注目の尺度 である私的自己意識と STAI の状態・特性不安と 主観的心配度が有意に相関することを示した。こ のように自己注目することによって抑うつ・不安 などの否定的な感情が引き起こされることにつ いて多くの知見が示されてきた。しかし，近年， 意図的な感情制御方略としてその有効性が注目 されているマインドフルネスでは自己に注目す ることによるポジティブな側面について言及さ れている(Teasdale，1999)。それは従来の否定的 な感情を引き起こす不適応的な自己注目は分析・ 熟慮などを伴うのに対し，マインドフルネスなど の適応的な自己注目では直接的・直感的・経験的 気づきを伴う自己注目を行うことによって否定 的な感情の生起を制御するというものである。本 研究では, 適応的・不適応的な自己注目が認知 · 感情に及ぼす影響について生理心理学的指標を 用いて検討した。

\section{【方法】}

形者: 大学生·大学院生 10 名。

刺激; 予備実験によって，覚醒度を統制した否定 的な画像と感情価を伴わない中性的な画像各 60 スライドを使用。

指挃：STAI-S, VAS (不安·緊張・快)，心拍(HR), 皮膚電気水隻 (SCL), 心拍変動性 (HRV：HF, LF/HF)。

手视き:シールドルームに掞いて電極装着後, べ ースラインとして 5 分間自律系指標を測定。その 後, 測定している心拍を音に変換しリアルタイム
でフィードバックし，注意操作を 5 分間行った。 適応的な自己注目の操作として心拍を 10 拍ずつ カウントさせ, 不適応的な自己注目の操作として, 心拍を抑制するよう教示し，10 拍ごとにどれく らい抑えることができたかを 10 段階で評価する よう教示した。その後, 認知課題を行った。認知 課題では黒注視点と赤注視点を各 $1000 \mathrm{~ms}$ 呈示 後, 画像をランダムに $500 \mathrm{~ms}$ 呈示。被験者には 画像の感情価を判断させた。また，500ms 以内 に判断できない時はその後に”TOO LATE”と表 示することで時間圧をかけた。ベースライン，注 意操作, 認知課題後に STAI-S と VAS を実施し た。数日後もう一方の注意操作を行った。

\section{【赫果と考察】}

STAI-S, VAS, 各生理指標において注意操作 2 (適応的・不適応的自己注目) $\times$ 測定時間 3 の 2 要 因分散分析を行った。その結果, VAS の緊張尺度 に交互作用が見られ $(F(2,18)=3.97, p<.05)$ ，

Ryan 法による下位検定の結果，注意插作後と認 知課題後に適応的な自己注目群は不適応的な自 己注目に対して緊張が低かった。また，HRVの LF/HF に交互作用が見られ $(F(2,18)=3.60, p$ $<.05)$, 下位検定の結果, 注意操作中に不適応的 な自己注目群は適応的自己注目に対して高い值 を示した。他の指標における主効果や交互作用は 見られなかった。認知課題における反応時間につ いて注意操作 $2 \times$ 画像の感情価 2 (中性的-否定的) の 2 要因分散分析を行った。その結果, 各群にお ける主効果や交互作用は見られなかった。

これらの結果から不適応的な自己注目によっ て注意操作中において交感神経活動が亢進し，そ の後の主観的な緊張感が持続した。また，その緊 張感は認知課題後も持続した。しかし, 認知課題 においては negativity biasはみられず，認知へ の影響は確認されなかった。本研究においては画 像の覚醒度を統制したので, 認知バイアスには覚 醒度が関与することも考えられる。
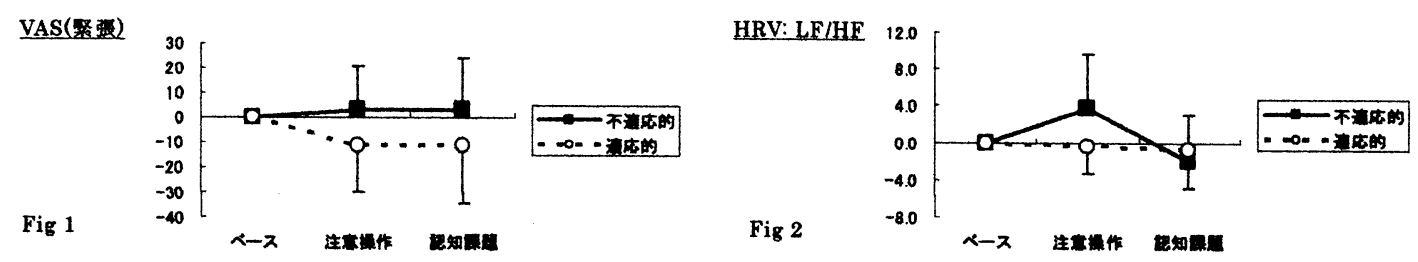


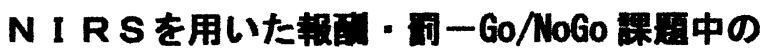 四内活到の湌討}

○野村 理朗（東海女子大学心理学科 NTT コミュニケーション 科学基磷研究所)

\#柏野牧夫 (NTTコミュニターション科学基碳研究所・科学 技術振興機構 ERATO 下條潜在脳機能プロジェクト)

衝動性は強迫性障害などの精神疾患との関連が示 されており, 近年は「キレる」行為の発生メカニズ 厶の解明人と向けて社会的要請も強く, 心理・脳機 能の両側面からの研究が行われている。実験室場面 においては, 例えば Go/NoGo 課題における Nogo 刺激 八の䛊反応数が, 衝動性の指標となることが知られ ている。同モデル実験系による fMRI やPET 等の神経 イメージング研究において, 衝動的反応の抑制には, おもに前頭前野腹外側部の右側が関与することが報 告されている(e.g. , Horn, 2003)。本研究では, NIRS を用いて Go/NoGo 課題時の脳機能測定を行うととも に, NEO-FFI, 刺激希求性尺度の 2 種の質問紙データ を収集することで, 中枢神経系指標, 行動指標, 質 問紙で得られた主観的指標との相関関係, すなわち 脳・行動・主観的心理状態の関係について総合的に 検討することを目的とする。

\section{方法}

右利きの女子大学生 23 人(平均年龄 $20.4 \pm 1.2$ 歳)に対し，多チャンネル NIRS(浜松ホトニクス社製， NIRO-200)を用いて中枢神経活動を観測した。装着 部位は両耳の上に $4 \mathrm{ch}$ (左), $8 \mathrm{ch}$ (右)が接するよう基 準を定め, Go/NoGo 課題遂行中の酸化へモグロビン $(0 x y-H b)$ と脱酸化へモグロビン $(\operatorname{deoxy}-\mathrm{Hb})$ の変化量 を計測した。本害験で用いた Go/NoGo 課題は、コ ンピューター・ディスプレイに提示される 2 析の数 字に応じて，ボタンを押すか押さないかの行動を選 択させるものであった。なお，キ一押しを正解とす る数字(Go 刺激), 反応抑制を正解とする数字(NoGo 刺激)についての明示的な教示は行わず, 個々の反応 にともなうフィードバックにもとづく行動修正を求 めた。実験条件は，正解すれば加点する RR 条件, 不正解であれば瑊点する PP 条件, キ一押しをした
場合に限り正解は加点, 不正解は减点する RP 条件, キー押し抑制した場合に正解ならば加点, 不正解で あれば減点する PR 条件からなる 4 条件の各々 108 試行を行った。課題終了後, 被験者に正答率に応じ た報酬を与え，また NEO-FFI 人格検査，ならびに 刺激希求尺度(木田，1993)への回答をもとめた。

\section{結果と考察}

\section{行動指標}

各条件の反応エラー・見逃しエラー，ならびに 反応時間の各々について 1 要因の被験者内分散分析 を行ったところ有意差は見られなかった。

\section{中枢神経系指標}

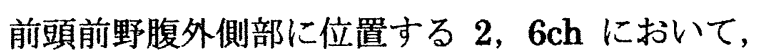
タスク開始にともなって脳血流量が増大し，タスク 終了より基線に復帰するという結果が得られた。こ れはf MRI·PET 実験において報告されている反応 抑制にともなう活性化領域と一致する。また, 前頭 腹外側部の左右に位置する $2,6 \mathrm{ch}$ 間の計測値の比 較を行った結果, RR 条件の oxy-Hb において右側と なる 6ch の有意な増加が確認された。さらには, 正 反応に報酬が伴う条件において，とくに $6 \mathrm{ch}$ の oxy-Hb の増加したことから, 報酬時における反応抑 制の機能元進が生じていることが予測される。

\section{主観的指標との相関}

主観的指標と行動指標間の相関分析の結果, NEO-FFI から得られた A(調和性)得点と PP 条件の RT 間で正相関が得られた。また，N(神経症傾向)得 点と PP 条件の CER 間での負相関, ならびに $\mathrm{A}$ (調 和性)得点と PR 条件の RT 間で正相関が確認される などの反応抑制時のメカニズムが明らかとなった。
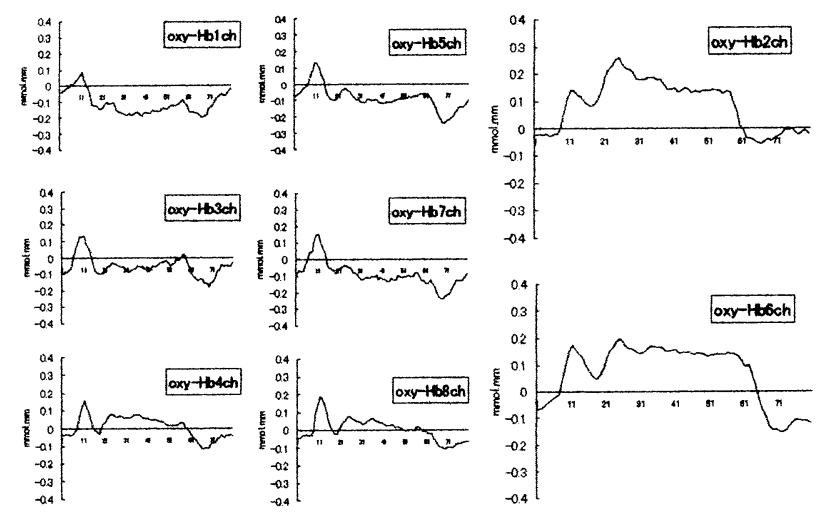

図 1. $\mathrm{oxy}-\mathrm{Hb}$ 变化量推移の加算平均結果 


\section{先行経験が後続する課題遂行時の課題成績・心理的反 応・心臟血管活動に与える影響

$\begin{array}{rll}\text { O齋藤 } & \text { 慶典 } & \text { (東海大学短期大学部[静岡] }) \\ \text { 市川 } & \text { 優一郎 } & \text { (日本大学大学院文学研究科) } \\ \text { 三村 } & \text { 覚 } & \text { (日本大学大学院文学研究科) } \\ \text { 政本 } & \text { 香 } & \text { (日本大学文理学部) } \\ \text { 依田 } & \text { 麻子 } & \text { (日本大学文理学部) } \\ \text { 久我 } & \text { 隆一 } & \text { (日本大学文理学部) } \\ \text { 山岡 } & \text { 淳 } & \text { (文京学院大学大学院) }\end{array}$

\section{緒言}

Saito\& Tomaka (2005)では, 課題遂行に対する否定 的な情報が常に提示される先行経験をした実験群は, その後の課題遂行場面において, 実際の成績を提示さ れる先行経験をした統制群に比べて動機が低く，遂行 成績も低いという結果であった。心臓血管反応につい ては，先行経験時に平均血圧において群間の差が見ら れたが, 後続する課題遂行時に差は見られなかった。 その理由として, 1. 否定的情報を受けている時点での み心臟血管活動が変化する可能性 と，2．否定的情報 を与えられながらの課題遂行期間が, 次の課題遂行期 間に影響を与えるほど十分な強度，または十分な時間 的長さを持っていなかった, ということが考えられた。 そこで本研究では，上記 2 点をふまえた検討を行なっ た。目標達成不可能条件, 目標達成可能条件, 目標な し条件を設定し，それらの条件の組み合わせによって， 達成不可能群, 達成可能群, 統制群に参加者を割り当 て, 先行経験がその後の課題遂行に与える影響につい て, 課題成績, 心理的反応, 心臟血管反応の 3 面から 検討した。

\section{方法}

【参加者】大学院学生および学部学生 15 名。参加者 は達成不可能群, 達成可能群, または統制群に無作為 に割り当てられた。

【課題】コンピュータを用いたストループ／逆ストル 一プ課題。色は赤・青・緑の 3 色を用い, 色名は漢字 で表示され，文字色または漢字の意味に対応するキー をできるだけ早く正確に押すよう教示した。目標達成 不可能・可能条件では, 課題遂行 1 分おきに目標を達 成したかどうかのフィードバックがディスプレイに表 示された。約 5 分間の課題遂行を 1 block とし, 各群 において, 条件を変え 5 blockずつ課題遂行を行った。
【目標達成不可能・可能条件の設定】実験の最初に練 習試行を約 5 分間行い(block1), 参加者の正答平均反 応時間と正答率を求め, その反応時間から $300 \mathrm{~ms}$ を引 いた值を目標正答反応時間, 目標正答率を $100 \%$ とし たものを, 目標達成不可能条件とした。目標達成可能 条件では，正答平均反応時間に $300 \mathrm{~ms}$ を足した値を目 標正答反応時間, 目標正答率を $70 \%$ とした。課題遂行 1 分おきに, 目標達成不可能条件では目標值と,「成績 がわるいです」という情報が表示された。目標達成可 能条件では, 1 分おきのフィードバック時に目標值が 表示されると同時に「よい成績です」という情報が表 示された。

【手続き】実験室に入室後, 安静記録を 5 分間行った。 練習試行を含む課題遂行期全 5 ブロックのうち, block2，block5 は全群について目標なし条件で，それ ぞれ課題を約 5 分間遂行した。Block2 での課題成績・ 主観的反応・心臟血管反応を分析のベースラインとし た。Block3 では, 全群とも目標達成不可能条件で課題 を遂行した。Block4では，達成不可能群は目標達成不 可能条件, 達成可能群は目標達成可能条件, 統制群は 目標なし条件で課題遂行を行った。各ブロックの後に 主観的課題難易度，動機などについての質問紙に記入 してもらった。

【測定指標】課題成績（正答率，正答反応時間)，心臟 血管反応 (心拍数: HR, 1 回拍出量: SV, 心拍出量: $\mathrm{C}$, 収縮期血圧：SBP, 平均血圧：MBP, 抁張期血圧：DBP, 全末梢抵抗：TPR), 課題遂行に関する質問項目得点。

\section{結果・考察}

Block4, block5 での各指標の群間比較を行った。 Block4において, 課題に関する質問項目の中の動機 に関する項目で有意傾向がみられ $(F(2,12)=3.12$, $p<.10)$, MBP において有意差 $(F(2,12)=4.41, p<.05)$, SBP，DBP において有意傾向 $(F(2,12)=3.25, p<.10$, $F(2,12)=3.83, p<.10)$ が見られたが, 課題成績に有 意差は認められなかった。また, block5においてす べての指標で有意差は認められなかった。このこと から, Saito\& Tomaka(2005)が用いた先行経験や, 本 研究で用いたような先行経験は, 後続する課題遂行 時の心臟血管反応に影響を与えない可能性が考えら れた。また, 本研究における先行経験時の血圧変化 の方向性は, Saito\& Tomaka (2005) と逆の方向性を示 した。この点については今後検討が必要である。 


\section{注意一感情モデルと能動的一受動的対処モデルの比較}

○松村 健太 (北海道大学大学院文学研究科. 日本学術振興会特別研究員)

澤田 幸展 （札幌医科大学医学部）

\section{【目的】}

精神的ストレス負荷時の血行力学的反応パターンを 決定する心理的要因については, Obrist(1981)の能動 的一受動的対処モデル(能動的対処で心臟優位反応パ ターン, 受動的対処で血管優位反応パターン)が現在に 至るまで有力な説明を提供してきた。しかしながら， このモデルでは説明のつかない状況が存在する (Waldstein et al., 1997)。そこで, この矛盾を解決する ため, Sawada et al.(2002, 2004)によって注意一感情 モデル(感情 $>$ 注意で心臟優位反応パターン, 注意 $>$ 感 情で血管優位反応パターン)が提唱された。本研究の目 的は, 注意一感情モデルと能動的一受動的対処モデル とを直接的に比較し，どちらのモデルの妥当性がより 高いかを調べることである。

\section{【方法】}

被験者 : 男子大学生 20 名(平均 $22.5 \pm 2.1$ 歳)。全ての 被験者からインフォームド・コンセントを得た。

課題と条件 : 感情>注意になると想定される課題とし て, 5000 から連続的に 13 を引き続ける暗算課題, 注 意>感情になると想定される課題として, 左右の動き が逆になる鏡映描写課題を用いた。そして，それぞれ の課題に, 能動的-受動的対処状況を, 松村・澤田(2004) の方法を用いて設定した。

装置 : 室温 $25^{\circ} \mathrm{C}$ の防音シールド室を使用した。外部と の連絡は，ヘッドフォンマイクを用いた。被験者は, 種々の測定装置を付けられた後, コンピュータのディ スプレイが備え付けられた机の前の椅子に座った。課 題のコントロールと刺激提示は, 全てコンピュータ (Power Mac G4)を用いて行った。

測定および算出した指標 : 画面に対する注意と喚起され た負の感情は，これらを直接尋ねる 2 項目の質問紙で 評価した。また, 前者については, 自発性瞬目数とし て客観的にも評価した。平均血圧は連続血圧計 (JENTOW-7700)から, 心拍出量は胸部アドミタンス 装置(NICOVIEW PA1100)から測定した。全末梢抵抗 は, TPR=MBP $/ \mathrm{CO}$ の式より算出した。

手続き: 7 分間の適応期間を設け, それに続く 3 分間
を安静状態とした。簡単な説明と練習の後, 課題を 5 分間実施した。その後, 5 分間の休顋をはさみ, これ をもう1セット繰り返した。

要因配置: 2 (課題: 暗算と鏡映描写, 被験者内) $\times 2$ (対 処: 能動的と受動的, 被験者間)であった。なお，1人 の被験者が行なったのは, 能動的と受動的対処のどち らか片方であり, 課題の提示順は, 被験者毎にカウン ターバランスした。

\section{【結果と考察】}

\section{1) 課題の性質}

注意 : 質問紙で測定した注意得点は，鏡映描写中>暗 算中であり，自発性瞬目数は，暗算中 $>$ 安静中 $>$ 鏡映 描写中であった。従って, 画面に対する注意は, 鏡映 描写中 $>$ 安静中 $>$ 暗算課題中であった。

感情 : 質問紙で測定した負の感情得点は，暗算中 鏡 映描写中であった。また, ストレス課題という性質上, 課題中>安静中であったはずである。従って, 喚起さ れた負の感情は，(鏡映描写中 $\fallingdotseq$ 暗算中) >安静中であ った。

まとめ : 以上より, 暗算中には感情 $>$ 注意, 鏡映描写中 には，暗算中と比較して相対的に注意 >感情となって いた，と判断することができる。

\section{2）心臟血管系の反応}

平均血圧は, 課題中 $>$ 安静中, 心拍出量は, 暗算中 $>$ (鏡映描写中 $\fallingdotseq$ 安静中), 能動的対処中 $>$ (受動的対処 中 $\doteqdot$ 安静中), 全末梢抵抗は, 鏡映描写中 $>$ (暗算中 $\fallingdotseq$ 安静中)であった。Figure 1 に, 各条件で誘発された 血行力学的反応パターンを示す。

\begin{tabular}{|c|c|c|}
\hline & 感情>注意 & 注意 >感情 \\
\hline 能動的対処 & 心茼優位反応 & 混合反応 \\
\hline 受動的対処 & 混合反応 & 血管優位反応 \\
\hline
\end{tabular}

Figure 1. 誘発された血行力学的反応パターン

\section{3）まとめと今後の展望}

本実験の結果は, 注意一感情モデルと能動的一受動 的対処モデルを，それぞれ支持するものであった。従 って, 本研究からだけでは, どちらのモデルの妥当性 がより高いかを決定することは不可能であった。今後, この問題をはっきりさせるためには, 条件設定方法の 工夫や, 負の感情を客観的に評価する指標（たとえば, 㱀眉筋活動）の導入などが必要であろう。 


\section{血行動態シフトと ERP P3a の慣れ}

$\bigcirc$ 加藤 有一 (札幌医科大学医学部)

松村 健太 (北海道大学大学院文学研究科・日本学術振興会 特別研究員)

澤田 幸展（札幌医科大学医学部）

中枢神経系が目標とする一過性ストレス時の血圧反 応性は、背景機序となる自律神経系の活動六進によっ て実現されている．ヒトにおける血行力学的研究は、 この血圧の上昇機序として、心拍出量の増加に特徵付 けられる心臟優位反応パターンと、主に全末梢抵抗の 増加による血管優位反応パターンがあることを示して きた。これによれば、同様な課題操作、そして同様な 血圧反応性下でも個人間で明暸に心臓血管系反応パ夕 ーンが異なる。

一方，持続的ストレス課題時には，血圧反応性とは 独立に血行動態シフト，すなわち時間経過に従った血 管優位型反応性元進が生じることが知られている。こ れは, 骨格筋への過剩血液潅流が原因となって生じる 非中枢性自動調節により引き起こされると考えられて きた。この自動調節による非中枢性血管収縮機能の立 進は，冠動脈疾患等のマーカーである血管内皮機能の 低下を生じさせると考えられており，心的ストレスと 心疾患との関連を考える上で重要な現象である. 事実, 血行動態プロフィールにより算出される自動調節の程 度と, 血流量依存性血管拡張度によって評価される血 管内皮機能の低下には密接な関連が示される.

本研究では, 持続的ストレス課題時の血管収縮機能 の交進に中枢制御機序が関与するのか否かを ERP P3a 成分の慣れの効果から議論してみたい.

[万法] 平均年齢 21.4 歳の男性 20 名が実験に参加し た。暗算時及び受動時に, 標準 $(1000 \mathrm{~Hz}$ 純音, $65 \mathrm{db})$ 及び逸脱（ホワイトノイズ, $85 \mathrm{db}$ ) 聴覚刺激を, それ ぞれ出現頻度 $90,10 \%$, ISI 1 秒で呈示した. 暗算時 には, 参加者に, 記憶した 4 つの数字を+, 一, ×を 用い自由に解答を求め, かつ, 事前の練習数以上の成 績を課した. 参加者は受動状態 3 分間, 及び暗算を 12 分間閉眼で試行した. Dinamap により平均血圧を 1 分間に 1 回の割合で測定した. 胸部インピーダンス電 極から得られる心電図 $R-R$ 間隔から心拍数を, 心電図 及び胸部インピーダンス変形波形を 1 分間毎に平均加
算した波形から 1 回拍出量を算出し, これらの積から 心拍出量を算出した。 また，平均血圧をこれで除した 全末梢血管抵抗を算出した.これらを基に, Gregg et al. (2000)に従い血行動態プロフィール $(\mathrm{HP})$ を算出した。 $\mathrm{ERP}$ は両耳架の平均を基準として $\mathrm{Fz}, \mathrm{Cz}, \mathrm{Pz}$ から記録 した $\mathrm{EEG}($ バンドパスフィルター1-30Hz)から加算平 均法により算出した. 分析は, 全ての指標に関して 3 分間の平均值で行った。そのため, 暗算時には， $1-4$ 期間のデータがあることになる。また, 暗算 1 期間目 の $\mathrm{HP}$ が被験者間平均值以上を示す個人を血管優位反 応者 $(\mathrm{N}=11)$, これ以外を心臓優位反応者 $(\mathrm{N}=9)$ と して分析した.

[結果及び考察] 暗算 4 期間目と 1 期間目の HP 值の 差を自動調節による血管収縮指標とすれば, 6 名が平 均值以上を示した。また，これを示す個人は全て心臓 優位反応者であった。

これまで，一過性ストレス課題に依存して出現する 前頭優勢な P3a 電位と血行動態プロフィールとの相関 関係 $(\mathrm{r}=.76)$ から, 中枢制御による心臓血管系調整 機序を提案してきた.この P3a-HP の相関関係は時間 経過に従い消失する $(\mathrm{r}=.10)$ ことから, 持続的スト レス時の血管抵抗の六進が非中枢性であることが示唆 される。しかしながら，一方、心蔵優位反応者は自動 調節が生じやすい傾向にあり、P3a は時間経過に従っ た慣れを示さなかった。また，血管優位反応者は時間 経過に従った血管収縮をほとんど示さず，P3a の慣れ が明瞭に観察できる（図 1)。これらの結果は，血管優 位者が，中枢制御により血管緊張度を弛緩することで 非中枢性血管収縮の充進を防いでいるのに対し，心臓 優位者は，持続的課題状況に慣れることが出来ないた めに末梢血管収縮の充進が促進されている可能性が示 唆される.

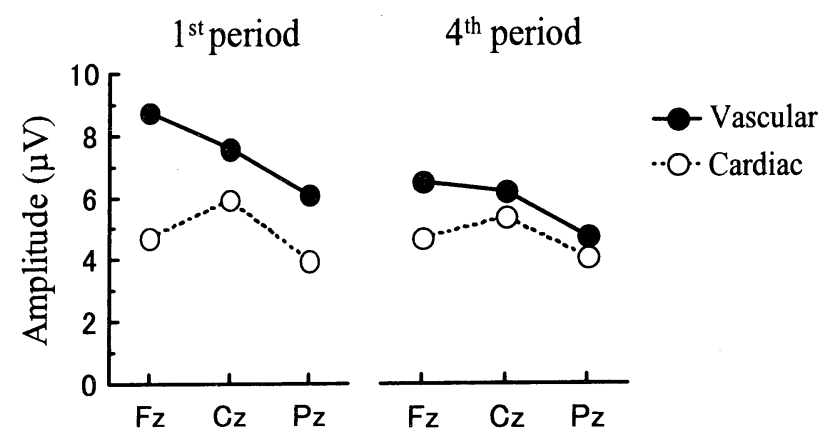

図 1. 暗算時の逸脱刺激に対して惹起された $\mathrm{P} 3 \mathrm{a}$ 振幅值を課題 期間，及び電極部位ごとに図示した. これを血管優位型反応者 (Vascular)と心蔵優位型反応者(Cardiac)に分けて図示した. 
ラットにおける事象関連電位 P3-like の

\section{下位成分検出の試み}

\author{
○服部稔広島大学大学院生物圈科学研究科) \\ 小野田 慶一（広島大学大学院医歯薬学総合研究科） \\ 坂田省吾 (広島大学大学院総合科学研究科)
}

\section{【序論】}

事象関連電位(event related potential: ERP) P3 は 注意資源と認知過程を反映していると考えられている。 しかし P3 の神経メカニズムは未だ解明されてはいな い。そのため近年 P3 の神経メカニズムを検討するた めのモデルとしてラットの P3-lik が注目されている (e.g., Yamaguchi et al.,1993; Shinba, 1997)。しかし ラット P3-like がヒト P3 と同様の成分かどうかにつ いては詳細に検討されていない。そこで本研究は P3 の下位成分である P3b に着目をし, P3-likeがヒト P3b と同様の成分かどうか， 3 音オドボール課題を用いて 検討した。

\section{【方法】}

被験体: Wistar 系アルビノラット（オス） 5 匹 装置:スピーカを装備したオペラント箱

課題: 3 音オドボール課題を用いた。標的刺激・非標的 刺激, 標淮刺激の刺激の周波数・提示確率はそれぞれ 標的刺激 $8 \mathrm{kHz} p=0.15$, 標淮刺激 $4 \mathrm{kHz} p=0.7$, 非標 的刺激 $2 \mathrm{kHz} p=0.15$ であった。音圧 $80 \mathrm{~dB}$ ，持続時 間 $50 \mathrm{~ms}$, 刺激間間隔 $4.5 \mathrm{sec}$ であった。標的刺激と 非標的刺激は被験体間でカウンタバランスをとった。 標的刺激提示後 $2.0 \mathrm{sec}$ 以内のレバー押し反応のみに 対して強化子を与えた。

手続き:被験体はレバー押し行動形成後, 単純反応課題 を行った。単純反応課題の学習成立後(正反応率 $85 \%$ 以上), 2 音オドボール課題を行った。 2 音オドボール課 題の学習成立後(正反応率 $85 \%$ 以上), 脳波測定用の手 術を行い, 3 日間の回復期間後 2 音オドボール課題 $(4$ セッション), 3 音オドボール課題(4セッション)遂行中 の脳波記録を行った。

記録・分析:前頭葉 (frontal cortex), 頭頂葉 (parietal cortex), 海馬 CA1, 海馬 CA3 の 4 部位から測定した。 時定数 $3.0 \mathrm{sec}$, サンプリング周波数 $1000 \mathrm{~Hz}$ で記録し, バンドパスフィルタ $0.5-60 \mathrm{~Hz}$ をかけ分析した。刺激 提示前 $200 \mathrm{~ms}$ から提示後 $500 \mathrm{~ms}$ 区間を加算平均し ERP を求め，それぞれの成分を同定した。

\section{【結果】}

行動指標: 学習獲得に要した期間は平均 $29.0 \pm 7.5$ セッション(Mean $\pm \mathrm{SE})$ であった。セッションによっ て課題成績に差がないか確認するため, 刺激メセッシ ヨンの 2 要因分散分析を行った。その結果, 刺激の主 効果が認められた $(p<0.001)$ 。セッションの主効果, 交互作用は認められなかった。このことから 4 セッシ ヨンを平均し, 課題成績の検討を行った。 4 セッショ ンの平均反応率は標的刺激 $79.6 \%$, 標淮刺激 $15.5 \%$, 非標的刺激 $16.0 \%$ であった。また平均正反応時間は $1.09 \pm 0.14 \mathrm{sec}$ であった。このことからラットでも 3 音オドボール課題が安定して遂行できることが示唆さ れた。

ERP: 3 音オドボール課題の総加算平均を求めた結果, 標的刺激に対しすべての部位で明瞭な P1，N1，P2 成 分が認められた(Figure 1)。標準・非標的刺激に対し ては認められなかった。P3-like は個体によって，標 的刺激に対し頭頂葉, 海馬 CA1 で認められた。

\section{【考察】}

個体によって課題に関連した刺激にのみ P3-like が 惹起された。このことから惹起された P3-like はヒト P3b と同様の成分であると考えられる。今後匹数を増 やして更なる検討を行う必要がある。またすべての被 験体で P3-like が惹起されているわけではなかった。 測定時の課題の安定性を重視し，長期の訓練を実施し たため馴化の影響が考えられる。このことを検討する ために訓練初期段階での脳波測定を行い馴化の影響を 検討する必要がある。

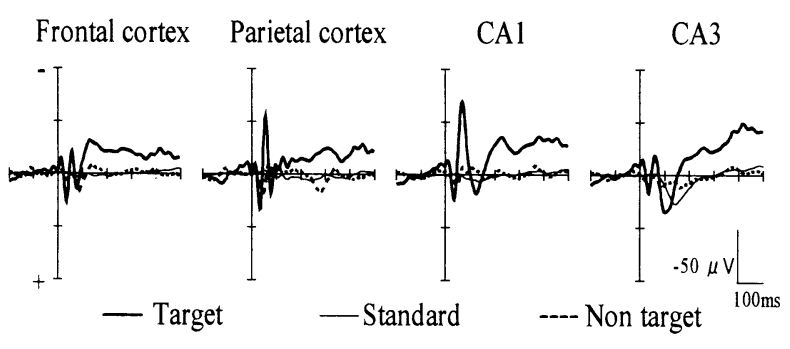

Figuer1. 4 セッションの総加算平均波形 $(5$ 匹)

\section{【引用文献】}

Shinba, T. (1997). Event-related potentials of the rat during active and passive auditory oddball paradigms.

Electroencephalogr Clin Neurophysiol. 104, 447-452.

Yamaguchi, S., Globus, H., Knight, R.T. (1993). P3-like potential in rats. Electroencephalogr Clin Neurophysiol. 84, 139-148. 


\section{日本剣道形にみられる注意と呼吸相の関係}

星野 聡子 (奈良女子大学文学部人間行動科学科)

\section{【目的】}

動作の正確性には，タイミングやポジショニング，グ レーディング, リプロダクションという出力面の能力 だけで決定されるのではなく，入力系に関わる状況把 握能力が問われる。これは、静的・動的視覚や運動感 覚に関わる認知能力や，対象物の動きに対する予測能 力を指す。随意性呼吸運動は，個人内の Locomotorrespiratory coupling だけでなく注意との関係が深く， 状況把握能力に少なからず影響を及ぼす最適な随意性 呼吸調節が必要であることも明らかにされてきた。

本研究では, 日本剣道形を課題とし, 対峙する相手 の動きに注意し素早く動作を起こすその運動状況から， 予測動作および反射的反応動作とに打突を区分し，双 方の打突時点の呼吸相に着目し，呼吸に反映される「準 備的構え」について検討することを目的とする.

【方法】

被験者：先手（打太刀）と後手（仕太刀）の 2 人一組 となり, 熟練者群 ( $\mathrm{H}$ 群), 非熟練者群 (L 群) の各 3 組, 計 12 名を被験者とした.

課題：日本剣道形の太刀の部（一〜七本目）を通して 10 セットを各組のペースで行わせた.

生理指標：マルチ・テレメータ（日本光電 WEB-5000） を用いて，呼吸曲線を鼻腔と口腔からサーミスタ式ピ ックアップセンサを用いて TC 5s で, EOG は, 垂直・ 水平方向を TC $1.5 \mathrm{~s}$ で導出し測定した.

\section{データの処理}

呼吸相の区分：呼吸（鼻腔）の呼吸位相から(1)吸気 相，(2)吸気相頂点，(3) “ため”呼吸相，(4)呼気相の 4 つに分類した. (3) “ため”呼吸相については，波形 から吸気後ポーズ期に極めて近い状態だが，いわゆる 止息した状態（息こらえの自発的無呼吸）ではなく, 的当て動作に先行するわずかな呼気を伴う準備段階で の“ため”を示すことからここう呼ぶこととする.

打突動作の区分：形七本目までを後手（仕太刀）の 打突方法によって，(1)「予測の打突」（一・二・三・五 本目）と(2)「反射の打突」（四・六・七本目）に分類し た. (1)は，先手（打太刀）が決意して掛かってくる技 を後手（仕太刀）が予測した上で，先手の技が功を奏 する前に後手が打突する勝負の機会である. (2)は，先
手の技の尽いた直後に，その技に応じて条件反射的に 打突する勝負の機会である.

打突場面ごとに先手および後手打突時の打ち手と 受け手の呼吸相について H 群と L 群の比較をした。

【結果と考察】

\section{1）「予測の打突」の呼吸相}

熟練群は，先手打突時から後手打突時にかけて，打 ち手・受け手ともに,ため呼吸相を多く示した (図 1). 熟練者には，相手の打突前から相手に対する注意を向 け，自分の打突の機会に対する「準備的構え」の持続 が，“ため”呼吸相に反映された。

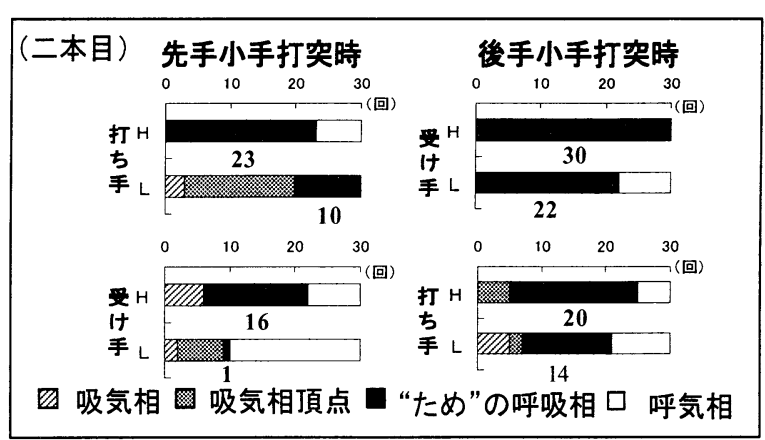

図 1 予測の打突時の呼吸相 (例 : 二本目)

\section{2)「反射の打突」の呼吸相}

先手打突時の打ち手に吸気相頂点が目立った。これ は剣の振り動作に伴う呼吸相である，後手打突時にお いては，非熟練群の打ち手は，先手の反射の打突と同 様に吸気相頂点が多く動作に伴う呼吸相であった。一 方, 熟練者後手の打突時はため呼吸相であった (図 2).

先手の動作は反射的になると, 動作に伴う吸気相に 変化した. しかし, 後手の打突時には, 熟練者では予 測の打突と同様に，ため”呼吸相がみらた，反射の打 突の機会においても, 熟練者には「準備的構え」が完 成されていることが呼吸相の変化から推察された.

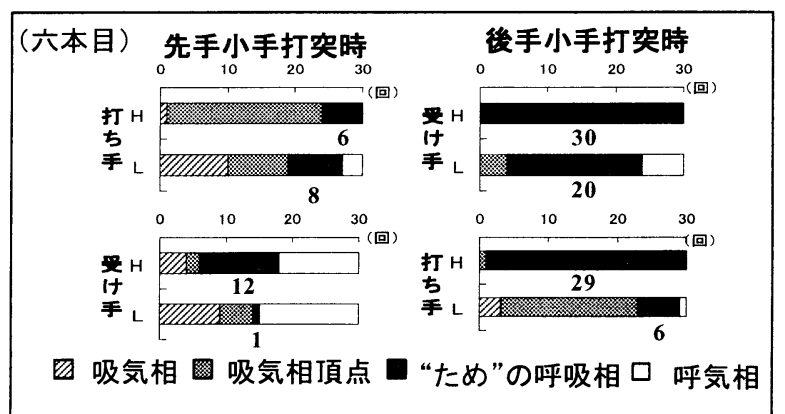

図 2. 反射の打突時の呼吸相（例 : 六本目） 


\section{腹式呼吸による不安低減効果・鎮静効果の検討} 吸気と呼気の比率による効果の比較を交えて

○松下 正輝

(広島国際大学大学院総合人間科学研究科)

佐野 友美 (広島国際大学心理科学部)

田中 秀樹 (広息国際大学心理科学部)

これまで, 就蔓前のリラクゼーションは運動やビジ ランス課題よりも入眠潜時を短縮させることが指摘さ れている(Browman \& Tepas, 1976)。一方，呼吸コン トロールは緊張・不安の低下など心理的なリラクゼ一 ションと関係しており(Clark \& Hirschman, 1990), さらに腹式呼吸時に呼気を長くすることでより副交感 神経活動が優位になることが示唆されている(片岡・渋 谷, 2002)。また脳の活動性の上昇が入眠期脳波段階 潜時を延長させ, 円滑な入眠過程を阻害することが阻 害することが報告されている(駒田ら，2000)。そこで 本研究では不安尺度やVAS, 脳波を指標とし, 腹式呼 吸による不安低减効果および鎮静効果を, 吸気と呼気 の比率による差を踏まえて検討することを目的とした。 方法

睡眠時間帯が規則的であり，心臟血管系に既往歴の ない健常な大学生 12 名(男性 6 名, 女性 6 名, 年齢 19.7 \pm 0.47 歳)を対象とした。また全ての実験参加者に目 的や方法を説明し, 書面で参加の同意を得た。

あらかじめ睡眠生活習慣に関する質問票と状態 - 特 性不安検査(STAI), 主観的な眠気の日内変動について 尋不るSSS(Stanford Sleepiness Scale)への記入を求 めた。実験は, 一日のうち, 最も覚醒度の高い時間帯 に実施した。つぎに実験参加者をSTAI の特性不安得 点がほぼ均一になるよう 2 条件 (吸気対呼気； 1 対 1 , 1 対 2)に割り当て, 実験順序は条件間でカウンターバ ランスをとった。腹式呼吸の前に 3 分間, 安静閉眼し てもらいこれをべースラインとし,ベースライン前と, 腹式呼吸後の安静の後, STAI, Visual Analog Scale(VAS)の記入を求めた。VAS は眠気と集中力, 疲労, 意欲の 4 つを設問した。生理指標として, 脳波 (EEG), 眼電図(EOG)，サーモグラフィによる皮膚温 を測定した。脳波は 10-20\%法に基づいた $\mathrm{Fz}, \mathrm{Cz}, \mathrm{Pz}$, O1，O2 の 5 部位より, 左右両耳梁を基準電極として 時定数 $0.3 \mathrm{~s}$ で導出した。分析には対応のある $\mathrm{t}$ 検定と 繰り返しのある 2 要因の分散分析を用いた。

\section{結果と考察}

状態不安について, 腹式呼吸後, 1 対 1 条件では 47.1 から 38.9 に有意な減少がみられた $(t(11)=5.57, p$ $<.001) 。 ま た ~ 1$ 対 2 条件は状態不安得点が 47.1 から 41.0 に腹式呼吸前に比べ有意に減少した $(t(11)=6.76$, $p<.001$ ) (図 1)。しかし，条件間においては有意な差は 見られなかった。さらに, 図 2 には, 腹式呼吸前後 3 分間の $\alpha, \beta, \theta$ 帯域活動の後頭部 $(\mathrm{O} 1, \mathrm{O} 2)$ のパワを 示した。 $\alpha$ 帯域活動の有意な上昇と $\beta, \theta$ 帯域活動の 有意な減少がみられた(図 2)。さらに腹式呼吸の終了直 後の 3 分間に比へ, 腹式呼吸終了 10 分後には $\theta$ 帯域 活動も有意に上昇し, VAS の眠気得点も有意に上昇し た。また左右手掌部の皮䖉温も有意に上昇した。以上， 本研究の結果から, 呼気比率による差異は認められな かったが，腹式呼吸による不安低減効果および，脳の 皮質活動に鎮静的に作用することが示唆された。

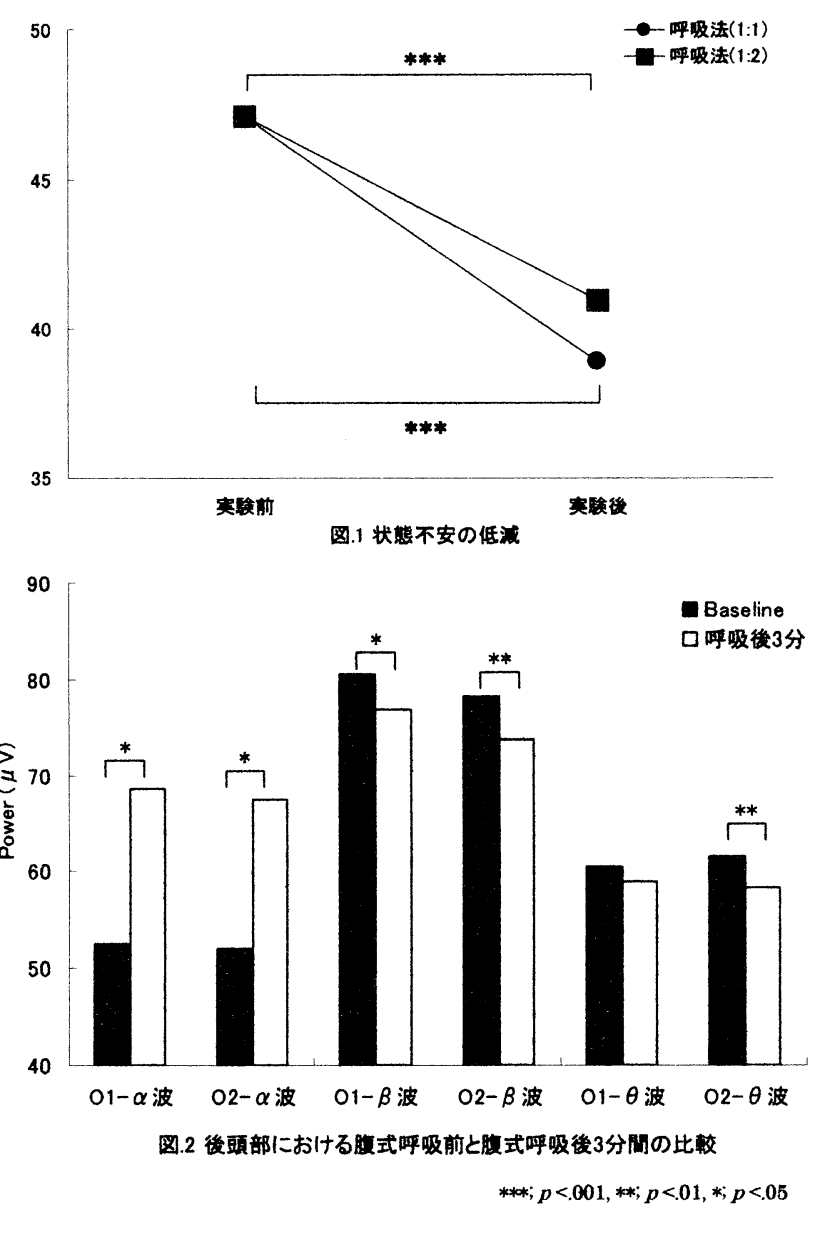

謝辞 実験に協力頂いた, 被験者の皆様及び広島国際大学 心理科学部, 板橋裕子さん・山本智子さんに感謝致します。 


\section{呼吸のセルフコントロール成樍と呼吸運動の関連性}

\section{$\bigcirc$ 寺井 堅祐 (福井赤十字病院・金沢大学大学院) \\ 梅沢 章男 (福井大学教育地域科学部)}

\section{1. 目的}

呼吸のセルフコントロール（SC）では，ストレスに より生じる換気の促進を抑えることが重要である.と ころが換気を抑えるのは初心者にとつて難しい課題で あり，ときとして過呼吸が引き起こされる危険性があ る.胸郭と腹部の呼吸運動変化が過呼吸をもたらす一 因になっていることが推察される. 本研究の目的は, 呼吸 $\mathrm{SC}$ の達成度と, 胸郭・腹部の呼吸運動変化との関 連性を明らかにすることである，具体的には，呼吸 SC の成功ケース, 失敗ケースで観察された呼吸運動変化 について比較検討した。

\section{2. 方法}

被験者：18〜26 歳の健康な男女 15 名.

刺激 : 暗室内のベッドに仰臥した被験者に対し, $20 \mathrm{~min}$ の安静時測定（pre-rest：PR）に続き, 3 min の暗算 課題と $2 \mathrm{~min}$ の寒冷昇圧課題をそれぞれ 2 試行ずつ実 施した。課題の呈示順は被験者間でカウンターバラン スした，また暗算と寒冷昇圧では，すべての被験者に 対して呼吸 SC 課題を併せて求めた.

呼吸 SC 課題: 分時換気量 (MV) を抑える呼吸 SC を求 めた．呼吸 SC の手がかりとして，呼吸サイクルごとの MV 変化を視覚的にフィードバックし, PR に比べて MV を低下させるように教示した。

測定指標 : 被験者の胸郭と腹部に RESPITRACE のトラン スデューサを巻きつけ，呼吸運動を連続記録した．測 定記録をもとに，胸部と腹部の呼吸運動振幅と両部位 の振幅比率 (胸郭 /腹部) を算出した. また, 胸郭と 腹部のずれ時間 (胸郭一腹部) を, 吸気開始時 $\left(\mathrm{LAG}_{\mathrm{INXP}}\right)$, 呼気開始時 $\left(\mathrm{LAG}_{\mathrm{EXP}}\right)$ について算出した.この值が正で あれば腹部の運動が胸郭に先行し，負であれば胸郭が 腹部に先行することを意味する。ささらに，呼吸流量計 により呼吸数, 1 回換気量, 分時換気量を求めた.

\section{3 . 結果と考察}

各課題における MV 変化を分析したところ, 呼吸 SC 成功者では，15名中 2 名の被験者が PRよりもMVを抑 えることができず，10 1/min を超える MV を示してい た. 2 名の呼吸を分析したところ, 一方は呼吸数が 1
分間に 15 回を上回っており,もう一方は 1 回換気量が 約 2L にまで増加していた，呼吸 SC の失敗には，呼吸 が過度に速くなる場合と，過度に深くなる場合がある ことを示唆する結果である. なお, 残る呼吸 SC 成功者 13 名では，呼吸数が 1 分間に 3-20回，1 回換気量が $0.3-1.3 \mathrm{~L}$ の範囲に分布していた.

次に, 呼吸 SC の達成度と呼吸運動との関連性につい て検討した。具体的には，呼吸 SC 時の MV と呼吸運動 5 測度の変化量との相関係数を求めたところ, 振幅比 率を除いて有意な相関を認めた。 FIG，1 には，MV と $\mathrm{LAG}_{\mathrm{INSP}} \cdot \mathrm{LAG}_{\mathrm{EXP}}$ 変化量との散布図を示した。被験者 15 名の全試行の結果である. 呼吸 SCに成功した試行につ いては○，呼吸数増加で呼吸 SC に失敗した試行を $\mathrm{O}$, 換気量増加で失敗した試行を $\triangle$ で示した. 呼吸 SC に失 敗した試行は， $\mathrm{LAG}_{\mathrm{INSP}} \cdot \mathrm{LAG}_{\mathrm{EXP}}$ がともに負の值であるの がわかる、これは胸郭が腹部に先立って動き始めて, 吸気と呼気が行われたことを示す結果である.さらに 胸郭・腹部の振幅, そして比率について同様の分析を 加えたが，呼吸 SC に成功した試行と失敗した試行の間 に明確な違いはなかった。

Fig. 1 に示した結果から，少なくとも腹部の動きが 先行している試行においては, 安静時を上回るMV 増加 は生じていないことが確認できる，従って，呼吸 SC で は, 腹部の動きが胸郭よりも先行した呼吸（腹式呼吸） を訓練することが過呼吸を回避する方法になると考え られる。また呼吸 SC 時の呼吸数と 1 回換気量は広い 範囲に分布したことから, 過呼吸が起こりにくい適正 な範囲にコントロールする必要性も指摘できる.

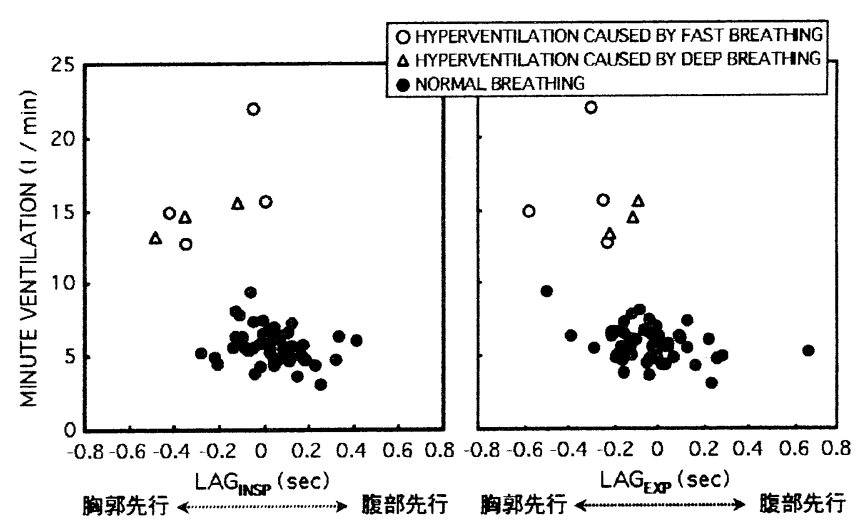

Fig. 1 呼吸 SC における, 分時換気量と吸気開始時 (左) ・呼気開始時 (右) の胸郭一腹部ずれ時間変化量 との関倸 
対人不安場面における自己呈示欲求および自己呈示効 力感の変化に伴う心臓血管活動と心理的反応

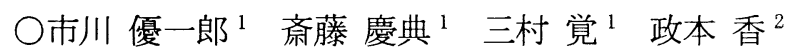

依田 麻子 $^{2}$ 久我 隆一 ${ }^{2}$ 山岡 淳 $^{3}$

(1 日本大学大学院文学研究科) ( ${ }^{2}$ 日本大学文理学部)

${ }^{3}$ 文京学院大学大学院)

\section{【目的】}

Leary（1983）は，対人不安レベルを規定する要因 として, “自己呈示欲求” と“自己呈示効力感” を挙 げ，それらの変数が，相乗的に影響し，対人不安レべ ルを上昇させると報告した。本研究では，それらの変 数が実験的対人不安場面における心臓血管活動および 心理的反応に及ぼす影響を検討した。

\section{【方法】}

害験参加者: 大学生 20 名（男性 10 名, 女性 10 名, 年齢 $20 。 0 \pm 0$ 。94 歳)

生理的指標 : 実験参加者の非利き手第 3 指中節部に 測定用カフを装着し, 携帯型連続指血圧測定装置 PORTAPRES（TNO-TPD BMI 製）にて測定した連続血圧波 形から，波形解析ソフト Beat Scope（TNO-TPD BMI 製) を用いて SBP, DBP, MBP, IBI， C0, TPR の拍動毎の值 を算出した。

心理的指標：Zuckerman（1960）による AACL の Anxiety Plus 項目 6 項目と Anxiety Minus 項目 3 項目 （米村・生和, 1990）を用いた。加えて, PANAS（Watson, Clark \& Tellegen, 1988) の日本語版（佐藤・安田, 2001), また, Spielberger（1966）による STAI-S の日 本語版（水口・下仲・中里，1991）を用いた。

実験手続き : 実験参加者は実験室に入室後, 実験参 加承諾書にサインを行なった。その後測定用のカフの 装着を行ない，実験を開始した。はじめに, ベースラ イン測定として開眼安静条件（5 分）の記録を行なっ た。その後, 実験参加者に対して, 大学 4 年生の評価 者（男女 1 名ずつ）からスピーチ能力についての評価 が行なわれることを教示した。そして，スピーチの準 備を行なう予期条件（3 分）と, 実際にスピーチを行な うスピーチ条件（3 分）, スピーチ後に安静状態である 回復条件（3 分）を行なった。スピーチのテーマに関し ては, 時事的なテーマ 10 題の中から実験参加者が選択 した。全条件を通して生理的指標を測定し，各条件終 了後に心理的指標として質問紙に回答を求めた。予期
条件終了後には, Visual Analog Scale（VAS）を用い て, スピーチの評価に対しての自己呈示欲求および自 己呈示効力感を測定した。評価者は参加者と同年齢ま たは年上の男女各 1 名であった。

\section{【結果と考察】}

VAS によって得られた自己呈示欲求および自己呈示 効力感の值から全実験参加者の中央值を算出し, 両変 数の高低で実験参加者を分類し, 従属変数とした。

生理的指標 : 自己呈示効力感の高低で分類し, 分散 分析を行なった結果, SBP, DBP, MBP の平均変化率にお いて群間の主効果が見られた（Figure 1)。この結果か ら, 自己呈示効力感の低い実験参加者は, スピーチ中 の血圧がより上昇する可能性が示唆された。自己呈示 欲求の高低との関係はいずれの生理的指標も統計的に 有意ではなかった。また, 自己呈示欲求の高低 $(\mathrm{H}, \mathrm{L})$ および自己呈示効力感の高低 $(\mathrm{H}, \mathrm{L})$ の両変数を合わせ て HL，HH，LL，LHに分類したところ，統計的に有意で はないが，HLが最も高く，LHが最も低い傾向が見られ た。以上の結果から, 対人不安場面において, 両変数 の相互作用が心臟血管活動に影響を及ぼしている可能 性が考えられる。

心理的指標 : 自己呈示効力感の高低で分類し, 分散 分析を行なった結果, PANAS ネガティブ感情得点の平均 変化值において群間の主効果が見られ，STAI-S におい て群間で有意傾向が見られた。この結果から，自己呈 示効力感の低い実験参加者は, スピーチ中のネガティ ブ感情および不安感がより上昇する可能性が示唆され た。また, 自己呈示欲求の高低で分類し, 分散分析を 行なった結果, ポジティブ感情得点で群間の有意傾向 が見られた。

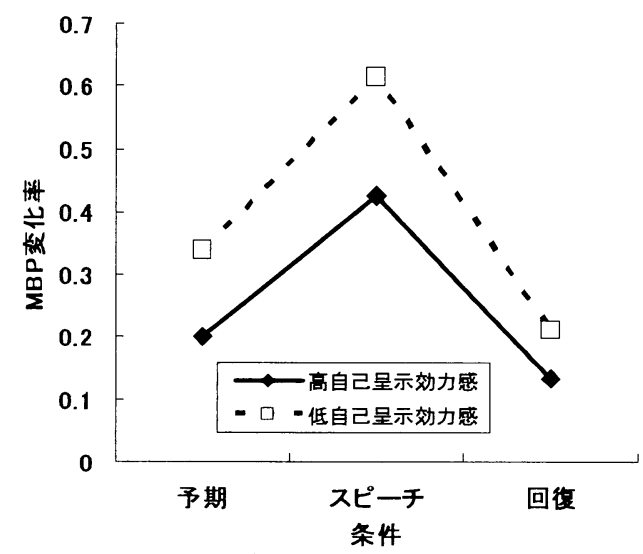

Figure 1. 自己呈示効力感の分類による MBP の平均变化率 
評価的状況下でのストレスに対する心臓血管反応

山田クリス孝介（日本大学大学院理工学研究科）

\section{1.はじめに}

従来，実験参加者の実験室内での行動を観察するた めにビデオカメラによる撮影が行われてきた。しかし， この手法は実験を実施する上での配慮に留まり，実験 参加者に与える影響が積極的に検討されることは少な かった。近年，評価的な状況が課題中の心臓血管反応 パターンに異なる影響を及ぼすことが言われ（長野， 2005），評価的な状況が心臟血管反応に少なからず影 響を及ぼすということ実証されている。そこで，本研 究では実験室実験において従来から頻繁に用いられて きたビデオカメラによる撮影を評価的状況に設定し， ストレス課題に対する心臓血管反応について検討した。

2. 方法

実験参加者 男子大学生および大学院生 38 名（20-29 歳）が参加した。全員からインフォームド・コンセン トを得た。参加者は心臟血管系に既往歴はなかった。 課題 プログラム化したクレペリン様課題を用いた。 参加者は，ディスプレイの中央部に表示された $2 つ の$ 1 析の数字を加算し，下一桁のみをテンキーを用いて 回答した。回答が終わるとすぐに次の数字が表示され， 終了の合図があるまで回答し続けた。

指標 収縮期および拡張期血圧（SBP および DBP）を 非侵襲的かつ連続的に測定した。心電図およびインピ ーダンスカーディオグラフィを用いて心臓活動を記録 した。レーザードップラー血流計により血流量（BF） を左手第 2 指指腹より測定した。上記 SBP, DBP, BF, および前駆出期 (PEP), 一回拍出量 (SV), 心拍数 (HR), 測定後にオフラインにて算出された心拍出量 $(\mathrm{CO})$, 全末梢抵抗（TPR），圧反射感度（BRS）を心臟血管指 標として用いた。

手続き 各種電極類の装着後, 安静状態を約 10 分間測 定した。その後, 課題の操作説明を行い，1 分間の練 習を行った。練習後, 参加者はビデオカメラによる撮 影を行う条件（評価条件：E）と行わない条件（非評 価条件 : NE）の両条件下で各 4 分間課題を行った。条 件の順序はランダムに提示された。条件 Eでは，撮影 後, 参加者の行動が数名の専門家によって評価される ことが伝えられた。また，課題はできるだけ早くかつ 正確に行うよう求められた。

\section{3. 結果と考察}

各指標について 1 分間の平均值を算出し，反応性得 点 (課題時一安静時) を求めた。指標ごとに2 (条件 : $\mathrm{NE} ， \mathrm{E} ） \times 4$ （ブロック：B）の反復測定による二元配 置分散分析を行った。有意水準は $5 \%$ とした。その結 果, $\operatorname{HR}(F(1.88,65.65)=4.58, p<.05)$ と BRS $(F(2.46$, $51.59)=3.23, p<.05 ）$ においてのみ交互作用が有意で あった。多重比較の結果，HRにおいて，NE 条件では B2，B3，B4 よりも B1 が高く，E 条件では B2，B3， B4 よりも B1 が高く, B3 よりも B4 が高かった。また, BRS において， NE 条件でのみ B1 よりも B3，B4 が高 く, ブロックでは B3 でのみ $\mathrm{NE}$ 条件よりも $\mathrm{E}$ 条件の ほうが低かった。その他すべての指標に有意な交互作 用および条件の主効果は認められず，ブロックの主効 果のみ有意であった $(p s<.05)$ 。各指標のブロックの 効果は概して, B1 で活性化し，時間が経過するにつれ てベースラインへ戻る傾向を示した。

HR は両条件ともに課題の初期に活性化し，徐々に ベースラインへと戻っていくということが示唆された。 しかし，BRS はNE 条件においてのみ変化が認められ たこと，また，B3において条件間に差が検出されたこ とから, 副交感神経の活動は $\mathrm{E}$ 条件よりも $\mathrm{NE}$ 条件で 活発であったと考えられる。さらに，HR で両条件と もに同様な変化を示し, BRS の $\mathrm{E}$ 条件で変化がなかっ たことは, NE 条件よりも $\mathrm{E}$ 条件で交感神経活動が大 きく働いていた可能性を示唆する。したがって，評価 的状況によって心臓交感神経が賦活されたと考えられ る。しかし, 血行力学的には両条件の違いが明確にさ れなかった。これは, ビデオカメラによる撮影が評価 状況として強度の低いものだったと考えられるため （長野，2005），より強度の高い評価状況での検討が 必要である。
HR

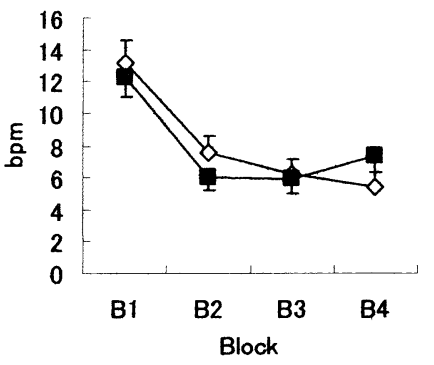

BRS

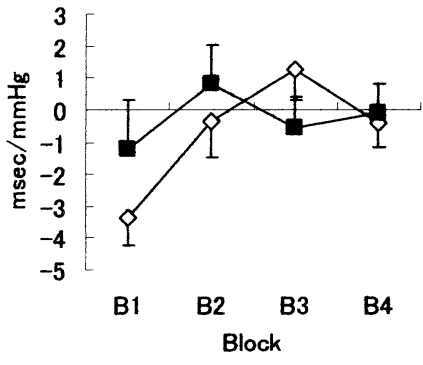

E条件〉NE条件
Fig. 1 HR と BRS の各条件の反応性得点の変化 


\section{リラクゼーション時における近赤外光を用いた脳血流 と脳波との関係について}

○内田誠也（財団法人厸・オー・エ-健康科学センター） 菅野久信（財団法人厸・オー・エ-健康科学センター） 山岡 淳（文京学院大学大学院、

財団法人厸・オー・エー健康科学センター)

\section{1.はじめに}

近年, NIRS（近赤外分光）法による脳機能のイメージ ングの研究が，盛んに行われている。非侵襲的にヒトの 脳血流の変化をマッピングできるために，様々な高次脳 機能の研究に応用されている。しかし，脳血流量と脳内 の電気活動の相関については，あまり研究されていない.

我々は、昨年音楽による脳血流量の変化と脳波の相関 関係を調べたが、本研究では、気功に類似したリラクゼ ーション法を使って脳血流量の変化と脳波の相関を調べ た。

\section{2 対象}

対象は、13 名の健康成人で、男性 8 名、女性 5 名で、 平均年齢は 35.3 歳（SD6.8）であった。しかし、脳波お よび rSO2、HbI の同時記録で、アーチファクトや被験者 の状態等によって、記録や解析できないケースがあった ため、解析された対象は8名であった。

リラクゼーションの方法として、外気功に類似した岡 田式浄化療法 (OPT) が用いられた。36 歳男性の施術者が、 すべての被験者に対して、背面より施術を行った。

\section{3 測定および方法}

脳波は、多用途生体アンプ（TEAC 電子計測(株)、 Polymate）を用いて、頭皮上の 13ch（Fp1、Fp2、F7、F8、 Fz、C3、C4、Cz、T5、T6、Pz、01、02 : 国際 10-20 法) から、両耳梁をリファレンスとする単極導出で計測され、 $\alpha 1$ 帯域および $\alpha 2$ 帯域のパワ一值を解析した。脳血流は、 脳内酸素飽和度モニター（トステック、TOS-96) を用いて、 左右前頭部酸素飽和度（rSO2） と総へモグロビンの変動 に対応するへモグロビンインデックス $(\mathrm{HbI})$ が計測され た。実験の前後で、気分プロフィールアンケート (POMS) を用いて、心理的な気分の変化も調べた。

施術実験について、被験者は椅子に座つて 5 分間閉眼 状態で安静した後、15 分間施術を受けた。このとき、被 験者は、30 秒おきに開閉眼を行った。対照実験について は、被験者は 5 分間の安静後、15 分間椅子に座るのみで
あった。施術実験と対照実験は別の日に行われた。

\section{4. 結果}

Fig. 1 は、 30 代男性における Fp1 の $\alpha 1$ と左前頭部の rS02 の相関を示す。の゙施術実験の相関を示し、 $\triangle$ が対 照実験の変化を示す。施術実験の $\alpha 1$ と rS02 の相関が、 対照実験の相関より高い結果が得られた。8名の被験者に ついて統言十的に調べても、施術実験の $\alpha 1$ と rSO2 の相関 係数が、対照実験より有意に高いことが分かった。特に 左前頭部の rSO2 と Fp1、Fp2、F7、F8、Fz、C4、T5、T6、 $\mathrm{Pz} 、 01 、 02 の \alpha 1$ と相関係数について、施術実験が対照 実験より有意に高かった。

\section{5. 考察およびまとめ}

Moosman らの研究によれば、閉眼安静時の自律性 $\alpha$ 波と 脱酸素化へモグロビンとの相関が高いという報告がある ${ }^{1)}$ 。 本研究の対照実験では負の相関が強く、 $\alpha 1$ と脱酸素化へ モグロビン相関が高いことが推測され、Moosman らの報告 に同意する結果である。施術実験では、酸素化へモグロ ビンとの相関が高いことから、リラクゼーション効果が 脳代謝機能と脳波との間に何らかの影響をあたえたと推 測される。それらの相関関係については、今後の研究課 題である。

これらの結果より、脳波と脳内酸素飽和度の相関は、

リラクゼーション効果を評価する方法として有効である ことが示唆された。今後は様々なリラクゼーション手法 による変化の違いを調へたい。

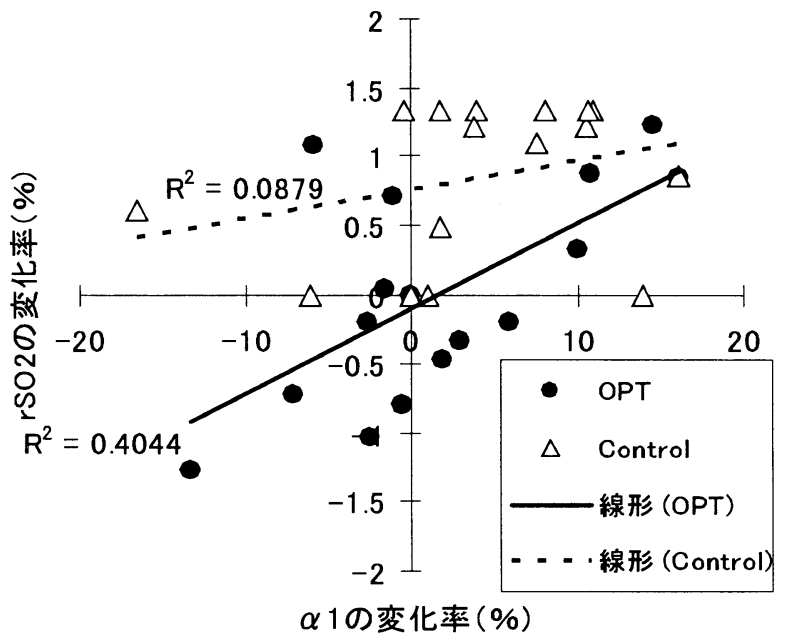

Fig.130代男性の $\alpha 1$ とrSO2の相関

1) Mbosmann M, et al: Neuroimage 20[1]: 145-58, 2003. 


\section{スピーチ不安喚起時の生理・心理的反応}

○小田原 幸 (川村学園女子大学大学院人文科学研究科)

田中 裕 (川村学園女子大学教育学部)

【目的】これまでのスピーチ不安研究において，他者の 存在と他者からの評価（他者要因）が検討されることが 少なく，使用される生理的指標は主に心臟血管系反応で あった。しかし，心臓血管系反応は呼吸の影響を受けや すい。そのため, スピーチ不安変動過程をより明確にす るには心臟血管系反応以外の生理的指標による検討が必 要不可欠である。本研究では, スピーチ不安の変動過程 における他者要因を再度検討対象とする。さらに，肉体 的・精神的なストレスによって上昇することが確認され ている唾夜から測定するアミラーゼ（以下アミラーゼと する）を使用することにより，スピーチ不安の変動過程 をより明確化することを目的とする。

[万法】 実験参加者: 女子大学生・女子大学院生 22 名 (平 均年齢 21.9 歳（ $\mathrm{SD}=2.4 ）$ 。生理指標: アミラーゼ及び 心拍数。心理指標 : スピーチ不安尺度（Slivken,K.E.,\& Buss,A.H.,1984），主観的不安感 AACL（米村 - 生和, 1992），およびあがり状態質問紙（有光・今田，1999a）。 行動指標：スピーチパフォーマンスを BCPA （Mulac,A\&Sherman,A.R.,1974）にて評定。

【手続き】実験参加者はスピーチ不安尺度得点によって 2 群に分けられた後, プレッシャー条件（評価プレッシャ 一の有／無）にランダムに振り分ける。全参加者は, ま ず AACL 記入・心拍数測定（3 分）・アミラーゼ測定 (baseline)。その後3 分間のスピーチを実施。スピーチ実 施前に, 評価プレッシャー有群には, (1)心理学を研究し ている2名がスピーチを評価する。(2)スピーチの構成や 内容の分かりやすさ, 声の大きさや流暢さを評価の対象 とする。(3)評価者がやり直しを指示することがあると教 示。同様に, 評価プレッシャ一無群には, (1)発話に伴う 心理・生理的反応を測定する。(2) 2 名の学生は機械の于 エックを行うだけでスピーチを評価することはない。(3) いかなる場合でも, やり直しをさせることはないと教示。 評価プレッシャー教示終了後, スピーチのテーマ（自分 の将来について）を教示。3 分間の思案時間を与えた後に AACL 記入・心拍数測定・アミラーゼ測定 (pre-test)。プ レテスト期終了後, 評価者を入室させ, 3 分間のスピーチ を実施。スピーチ終了直後（心拍数のみスピーチ中のデ 一夕使用）にアミラーゼ測定・AACL・あがり状態質問紙 記入 (test)。その後 5 分間の安静期を設定。安静期後に 再度 AACL 記入・心拍数測定・アミラーゼ測定 (post-test)。
【結果】スピーチ不安得点により参加者 22 名中 17 名を 分析対象とした。今回は, 4 つの実験条件 (baseline, pre-test, test, post-test）における全参加者の心拍数，アミラーゼお よびAACLの平均値を分析対象とした。分析の際の有意 水準は $\mathrm{p}<.05$ とし, 分散分析の下位検定として Tukey 法を 使用した。心拍数 : 2 (スピーチ不安の高低 $) \times 2$ (プレ ッシャーの有無） $\times 4$ (セッション）の分散分析を行った 結果, 実験条件の主効果が有意であった。下位検定の結 果, baseline と test の間に有意差が認められた。また, セッションとプレッシャーの有無に交互作用が認められ た。アミラーゼ : 心拍数同様の分散分析を行った結果, 実験条件の主効果が有意であった。下位検定の結果, baseline と test 及び test と post-test の間に有意差が見 られた。また, 実験条件とプレッシャー条件の間に交互 作用が認められた（Fig.1）。 AACL：心拍数同様の分散分 析を行った結果, 実験条件の主効果が有意であった。下 位検定の結果, baseline と pre-test, test 及び pre-test, test と post-test の間に有意差が認められた。

【考察】本実験においては，心拍数・アミラーゼ共に， スピーチを予期する段階から方進し始め, スピーチ実施 時に最も高い測定值を示した。また, 評価プレッシャー を与えることにより，心拍数・アミラーゼが上昇した。 以上より, 評価を行う他者の存在が交感神経系を六進さ せる可能性が示唆された。加えてアミラーゼがスピーチ というストレス事態を鋭敏に反応することを確認するも のであろう。また, AACL はスピーチを予期する段階に おいてスピーチ実施時と同程度の值を示すだけでなく， 評価プレッシャーの有無に関わらず高い值を示した。こ れらのことから, AACL の増大はスピーチ場面という状 況に由来する可能性が示唆された。

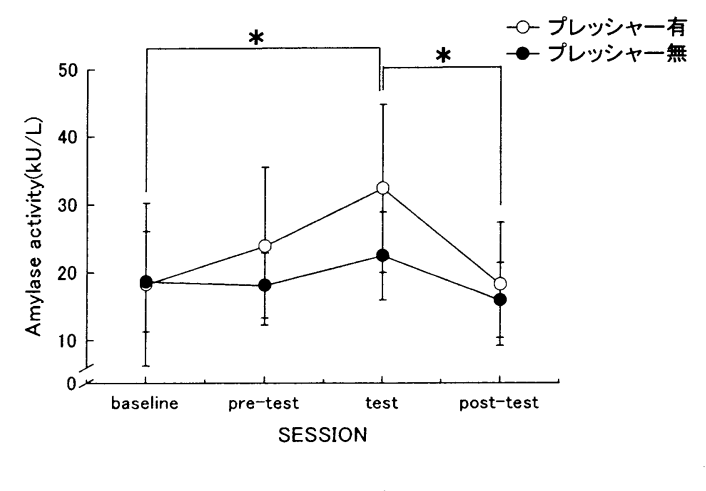

Fig.1 唾液アミラーゼと評価プレッシャーの効果

○報告は科学研究費補助金の補助（課題番号 15650143, 研究代表者：田中裕）を受けた 
急性ストレス負荷時の生理反応の個人差要因に関する 検砷

○山口 真緒 (愛知淑徳大学コミュニケーション研究科)

加藤 みわ子

伊藤 康宏 (藤田保健衛生大学衛生学部)

永 忍夫

清水 遵 (愛知淑徳大学コミュニケーション学部)

\section{目的}

ストレス反応の個人差を考えるとき，個人のストレス 而性にかかわる諸要素(情動, 認知, 社会的支持, 対処行 動など)に注目する必要がある。なかでも情緒性は, 個人 間のストレッサー感受性の違いに直接関係することから 一義的な影響要因であると思われる。本研究では, 情緒 性の違いが，無自覚ストレッサー条件下（ $7^{\circ} \mathrm{HDT}$ 姿勢） におけるストレス反忘に影響を及ぼすか否かを検討する 目的で, 安静座位条件, $7^{\circ} \mathrm{HDT}$ 条件下の内分泌指標, 自 律神経指標，および心理指標から検討した。

\section{方法}

\section{実験参加者}

矢田部ギルフォード性格検查を実施し，その結果から 情緒不安定群 7 名, 情緒安定群 8 名の 2 群を設けた。各 群の参加者はいずれも実験に承諾を得た健常な女子学生 (平均年齢 20 歳)であった。

\section{手続き}

参加者全員について,座位安静 20 分間の後, $7^{\circ} \mathrm{HDT}$ (頭 部を水平より $7^{\circ}$ 下げ,仰臥する姿勢)を 20 分間保った。 $7^{\circ} \mathrm{HDT}$ 前後に唾液の採取と感情評定を行った。また, 安 静座位および HDT 中の心電四を記録した。それぞれの睡 液中成分 (MHPG, HVA,CS) 自律神経応答および感情評定に 関して, 情緒不安定群と安定群を比較した。

\section{生理および心理指標の測定}

唾液中 MHPG，HVA 濃度は，永らの方法(2002)を用い， HPCL 法 3-カラムスイッチング方式により, 励起光 $280 \mathrm{~nm}$, 蛍光 $320 \mathrm{~nm}$, の波長で測定, 定量した。喠液中CS 濃度は, 酵素免疫抗体法を用いて検出器により波長 $450 \mathrm{~nm}$ で測定, 定量した。交感神経指標には, 胸部 3 点誘導法で 10 分間 測定した心電龱から得られた R-R 間隔のパワースペクト ルの高周波成分值 $(\mathrm{HF})$ と低周波成分值 (LF)の比 (LF/HF) を用いた。感情評定は Affect-Grid 法を用いて, 快一不 快感および，覚醒感を評定した。

\section{結果}

各指標に関して情緒性(安定・不安定) ×姿勢(座位・ $\left.7^{\circ} \mathrm{HDT}\right)$ の 2 要因混合分散分析を行った結果, MHPG 濃度 において情緒性と姿勢との有意な交互作用が認められた $\left(\mathrm{F}_{(1,13)}=4.77, P \times 0.05\right)$ 。下位検定の結果, 情緒不安定群 のみ $7^{\circ} \mathrm{HDT}$ で安静座位からの有意な MPP 濃度の上昇を 示した (図 1)。LF/HF に関しては, 姿勢要因の主効果が 認められた $\left(\mathrm{F}_{(1,11)}=5.97, P<0.05\right)$ 。すなわち, 安静座位 に比べ $7^{\circ} \mathrm{HDT}$ 条件で $\mathrm{LF} / \mathrm{HF}$ 值が有意に上昇した。その他 の指標に関してはいずれも有意差は認められなかった。

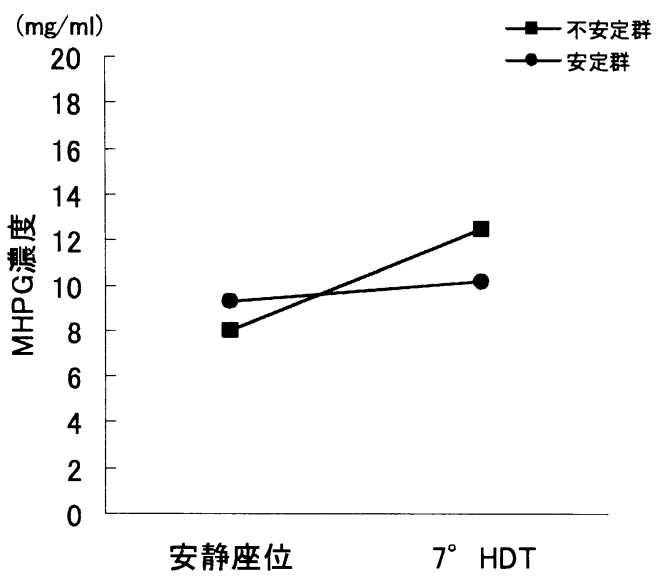

図 1.MHPGの変化

考察

本研究では, 個人差要因としての情緒性の違いがスト レス反応 (交感神経-副腎髄質系) としてのノルアドレナ リン代謝産物 MHPG 分泌に影響を与えることが示された。 すなわち, 情緒不安定型の人は無自覚なストレッサーに 対してもストレス反応を示すことが明らかになった。交 感神経指標の結果から $7^{\circ} \mathrm{HDT}$ 条件下では, 両群とも交感 神経優位となり，身体的にはストレス反応を起こしてい た。しかし，心理指標による快一不快，覚醒感は HDT に よる影響を受けなかった。また，唾液中 CS 濃度も HDT の 影響を受けなかった。これは,作動力や努力などの effort に加え distressなどの好ましくない感情を伴うことか下下 垂体一副腎皮質系ホルモンの増加に必要であるとする垣 本ら (1988)の示唆に一致している。以上の結果から, $7^{\circ}$ HDT 条件のような無自覚なストレッサーによる生体反応 感受性は情緒性と関連があること，内分泌ストレス反応 としての MHPG 分泌は $7^{\circ}$ HDT の体液移動, 深部感覚ある いは内臟感覚に，より敏感に反応する指標となり得るこ とが示唆された。 


\section{要求度と裁量度が生体に及ほすす影㝵}

一職業性ストレスモデルを参考に一

$\bigcirc$ 渡邊 光 (愛知淑徳大学コミュニケーション研究科)

櫻井 優太（愛知淑徳大学コミュニケーション研究科）

清水 遵 （愛知淑徳大学コミュニケーション学部）

【問題と目的】

職業性ストレスは，職場環境間で多様な様相を持つ事 から，それを普遍的に理解する事を目的として，多くの 職業性ストレスモデルが構築されてきた。Karasek (1979)は「Job Demand, Job Decision, and Mental strain Model」を提唱した。本モデルは，仕事の質的な いし量的負荷を示寸「要求度」と, 職場における業務に 関わる行動の自由度を示す「裁量度」の 2 要因から構成 され，それぞれの要因の水準によって職業性ストレスを 4 種類に分類した。中でも, 要求度が高く裁量度が低い 労働環境は，精神的・健康的被害を訴える度合いが最も 高いとされ，多くの>ィールド研究の結果がそれを支持 している。しかし，フィールド研究の手法では剩余変数 となる要因の統制に限界を有する事から, より統制され た実験環境下での検討が求められている。そこで本研究 では, Karasek (1979)のストレスモデルを参照した計算 課題を作成し，その課題によるストレス反応について生 理学的指標を用いて検討する。

\section{【方法】}

計算課題 : 2 析の足し算を連続的に実施した。各ブロッ クには達成すべき正解数ノルマが設定された。このノル マは参加者の計算能力に応じて計算される值で, 各参加 者が 120 秒の間に到達されることが予想される問題数で あつた。これを 6 ブロック実施した。要求度要因はブロ ックに設定される制限時間を変数とし, 高群は 120 秒, 低群は 150 秒が設定された。参加者は制限時間内にノル マを達成するよう教示された。裁量度要因は, 解答内容 についてのフィードバック妥当性を操作変数とした。全 試行において実際の解答とフィードバックの整合性があ る群を高群とし, 半分の試行において実際の解答内容に 関わらず，正誤どちらかのフィードバックが無作為に提 示されるものを低群とした。これら水準の組み合わせで 4 群が設定された。参加者 : 大学院生合計 43 名の参加 を得た。手続き: 参加者は, まず 5 分間の安静状態を保 つよう教示された (安静条件)。次に, 参加者は計算課 題を遂行した（課題条件）。安静条件と課題条件におけ
る LF/HF，BRS，唾夜中 CgA が測定され，安静条件を 基準とした課題条件の相対值が分析の対象となった。

\section{【結果と考察】}

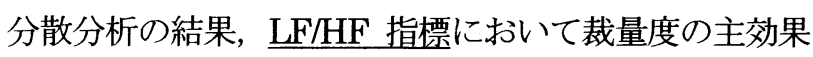
が有意であった $[F(1,39)=5.65, p<.05]$ 。裁量度低水準 は高水淮と比較して, 交感神経活動の充進が認められた (参照: 図 1)。BRS 指標では全ての群で副交感神経抑制 傾向を示した。特に, 裁量度高水準且つ要求度高水淮で は, 他と比較して最も低值を示し, 副交感神経の抑制を 示唆した。 $\mathrm{CgA}$ 指標では裁量度低水淮且つ要求度高水準 において最も高值を示しておりここから高い精神性ス トレスの傾向が伺われた(参照 : 図2)。

以上の生理指標の結果から, 裁量度低水準且つ要求度 高水準のような低い裁量と個人の要求資源を超えた高い 要求は, 高い精神・生理的負荷を示唆する。従って, 本 実験での結果は, これまでのフィールド研究との関連を 示唆するものであった。

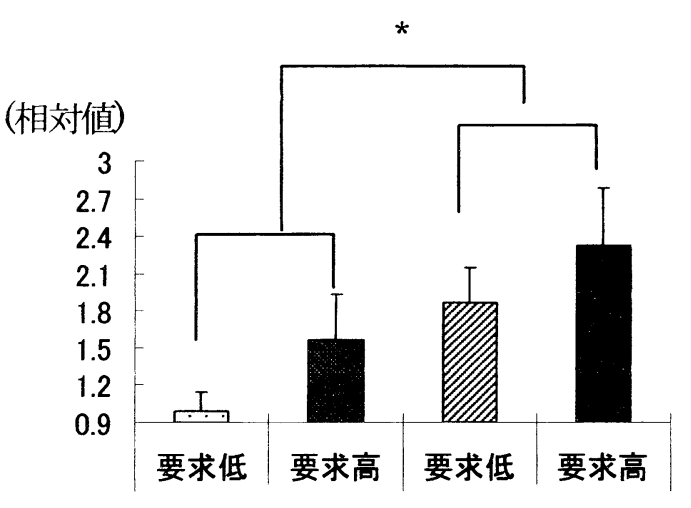

図 1 LF/HF の相対値分析結果

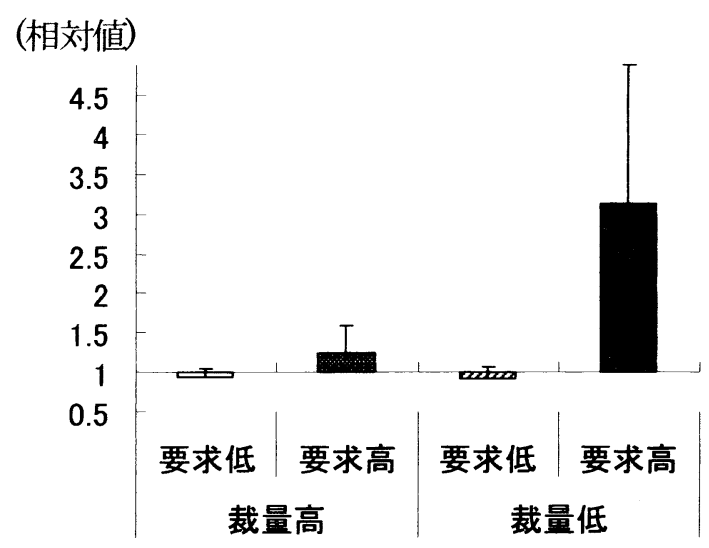

図 $2 \operatorname{CgA}$ の相対値分析結果 


\section{心理的ストレス課題時におけるガム咀嚼の 効果について}

$\begin{array}{cl}\text { O福居玲奈 } & \text { (県立広島大学大学院総合学術研究科) } \\ \text { 西澤 恵 } & \text { (県立広島大学保健福祉学部) } \\ \text { 平尾祐子 } & \text { (県立広島大学保健福祉学部) } \\ \text { 田丸政男 } & \text { (県立広島大学大学院総合学術研究科) }\end{array}$

1. 研究目的 : 咀嚼は, 唾液分泌の妄進や口腔内洗浄 などの生理的効果などが知られている ${ }^{1)}$ 。また，チュ ーインガムの咀礵は，これらの機能を更に促進すると 伴に, 心理面では覚醒作用やリラックス作用という相 反する二つの作用が報告されている。ガム咀嚼のスト レス軽減については，主に血漿中におけるストレス指 標物質であるカテコールアミンの低下が報告 ${ }^{2)}$ されて いるが，唾液中のストレス物質についての報告は少な い。そこで本研究では，精神性ストレス課題時におけ るガム咀嚼のストレス低減効果について，血圧や心拍 数などの生理学な指標, 及び唾液中のカテコールアミ ン (CA) 代謝物，分泌型免疫グロブリン (s-IgA) など の生化学的な指標物質から検討した。

2. 方法

（1）対象者：同意の得られた歯・口腔疾患のない健常 成人女性 9 名（平均年齢 21 。2 歳）を対象者とした。

（2）実験手続き：実験は，ガム咀嚼又は非咀嚼下で 15 分間の内田クレペリンテストを科す 2 群とガム咀嚼 のみの合計 3 群に分け, テスト前後には 10 分間および 30 分間の安静を，ビデオ視聴により統制した。

（3）ガム咀嚼: 咀嚼用ガムは粒タイプガムを用い，3 分ごとにガムを取り替える指示で，常に咀嚼を誘発す るようにした。咀嚼回数は咀嚼後のガムより溶出した 糖重量を測定し, 既知の咀嚼回数のガムにおける糖溶 出重量から作成した検量線より求めた ${ }^{33} 。 3$ 分間の推定 の平均ガム咀嚼回数士SEM は，ストレス群で $216 \pm 6.5$ 回, 課題時にビデオ視聴する群で $220 \pm 7.6$ 回であった。 また, 唾液採取は, 課題前, 直後, 15 及び 30 分後に 行い，サリベティのコットンを 1 分間，口に含ませ非 刺激的に唾液を採取した。唾液の 1 分間の分泌量は, 重量法により測定したが，今回の全て群及び何れの時 期においても唾液量には大きな差はなかった。

(4) 生理学的検索：心拍数, 血圧及び心拍変動 (HRV) について検討した。

（5）生化学的検索 : (1)s-IgA 量 : ELISA 法により定量
した。(2)CA 代謝物の定量：ドーパミン，ノルアドレナ リンの代謝物である homovanillic acid (HVA)， 3-methoxy-4-hydroxyhenyl acetic acid (MHPG) 量は, セミミクロ高速液体クロマトグラフシステムで分離し, 蛍光検出器で定量した ${ }^{4)}$ 。(3) $\alpha$-アミラーゼ活性の測 定 : ストレス測定器（COCORO Meter）で測定した。

（6）統計解析 : ノンパラメトリック検査の一つである Kruska1-Wallis 検定を用い，有意差が見られたものに ついて, Fisher の PLSD の下位検定を行った。

3. 結果と考察：(1)心拍数, 平均血圧及び HRV : ス トレス時では，ガム咀嚼に関わらず前後の安静に比し 有意の心拍数の上昇がみられたが，ガム咀嚼が心拍数 を抑制することはなかった。また平均血圧もストレス 群では大きな変動がなかった。HRV は全ての群で, 課 題時において交感神経活動の指標とされる LF/HF の増 加，副交感神経活動の指標の HF が低下したが，ガム咀 嚼には HRV でみる限り交感神経活動の抑制効果はなか った。(2)MHPG 及び HVA 量 : ストレス直後においける MHPG 濃度は，ガム咀嚼群で非ガム咀嚼に比し，有意な 低下を示した。また 1 分間採取の唾液中の全含有量で も低下傾向が示され, ストレスによる MHPG 量の増加を, ガム咀嚼が抑制した可能性が示された。一方, HVA 量 には大きな変動はみられなかった。(3) s-IgA 量 : ガム 咀嚼群ではストレス直後において $s-I g A$ 濃度及び 1 分 間採取の唾液中の全含有量ともに，非咀嚼群に比し有 意の低下が示された。s-IgA は急性ストレスで上昇す ること，本実験の唾液量には変化がないことから，ガ

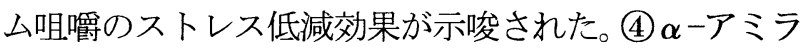
一ゼ活性 : 精神性ストレスで上昇することが知られて

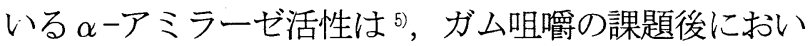
て著しい有意な上昇がみられたが，本実験ではガム咀 嚼による活性の低下効果は示されなかった。

4. 結論：本実験においてはストレス課題による臨床 生理学的な指標の増減を, ガム咀嚼は抑制しなかった。 しかし，喠液中のストレス指標物質であるとされる s-IgA や MHPG 量のストレス課題による増加を，ガム咀 嚼は有意に抑制したことから，ガム咀嚼にはストレス 低減作用の女ることが示された。【文献】1）鈴木政登ら： 食品・食品添加物研究誌 208 (8)：639-647（2003）。2）石山育朗ら： 日本咀嚼学会 8 (1) : 42-52 (1998)。 3) 倉橋昌司:医学のあゆみ 205 （2）：173-174(2003).4）永ら：生物試料分 $25: 178-183(2002)$. 5）山口昌樹ら：医用電子と生体工学 39（3）：46-51（2001）. 


\section{ストレス生理指標としての唾液緩衝能の可能性}

一無自覚ストレッサー $\left(7^{\circ}\right.$ HDT $)$ 条件を用いて一

○加藤みわ子(愛知淑徳大学コミュニケーション研究科)

伊藤康宏 - 永 忍夫(藤田保健衛生大学衛生学部)

清水 遵(愛知淑徳大学コミュニケーション学部)

問 題と目的

近年，ストレス・マネジメントに関して，多く の研究者が注目をしているにも拘わらず，客観的な

「慢性ストレス生理指標」を扱っている研究は数少 ない。そこで我々は一昨年来, 生命維持に欠かせな い体内の酸塩基平衡の調節に関与する緩衝能に着目 し検討をしてきた。本研究では，自覚され難いが体 性感覚では急性ストレッサーとなりうる $7^{\circ}$ headdown tilt $\left(7^{\circ} \mathrm{HDT}\right)$ において, 慢性ストレスを 自覚する人と自覚しない人を喠液中コルチゾール濃 度, 感情評定を用いて比較することで, 唾液緩衝能 のストレス生理指標としての可能性を心理的及び生 理的に検討した。

\section{方 法}

手続き：実験参加者について，慢性ストレスを測 る目的で作成された CFSI（蓄積的疲労微候インデ ックス）の結果を基に, 参加者母集団の平均値（1 86.2 得点）より高得点の人を「ストレス群」，その 他を「健康群」として二群に分けた。座位安静の後, $7^{\circ} \mathrm{HDT}$ (頭部を水平より $7^{\circ}$ 下げ，仰卧する姿 勢）を 30 分間保ち, 感情評定・唾液採取を行った (Fig.1)。安静座位加ら HDT への变化率に関して, ストレス群と健康群を比較した。

\section{Experiment start}

$$
\text { ? } 20 \mathrm{~min}
$$

Rest sitting position (repose)

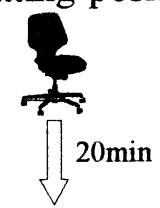

Saliva sampling Emotion measurement

Head Down Tilt (HDT)

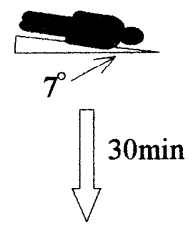

Saliva sampling Emotion measurement

\section{Experiment end}

Fig.1 Method of experiment
参加者 : ストレス群 5 名 (女性 5 名。平均年齢 $22.6 \pm 2.1$ 歳。CFSI 得点 $248.1 \sim 404.8$ 点), 健 康群 7 名（女性 4 名, 男性 3 名。平均年齢 $21.9 \pm$ 1.2 歳。CFSI 得点 $21.1 \sim 178.1$ 点）が実験に参加 した。いずれも実験に承諾を得た健常な大学生及び 大学院生であった。

測定 : 唾液緩衝能は, Ericsson の方法（1959）を 準用し， pH は試験紙で測定した。唾液中コルチゾ 一ルは, 酵素免疫抗体法を用いて検出器により波長 450nm で測定, 定量した。感情評定は Affect-Grid 法（1989）を用いて, そのときの快一不快感及び, 覚醒一不覚醒感を測定した。

\section{結 果}

唾液緩衝能において, 慢性ストレス感の違いによ る HDT の影響の差が認められた $\{t(10)=4.56, p<0.0$ $5\}$ （Fig.2）。その他, 快一不快感・覚醒一不覚醒感 および唾液中コルチゾール濃度においては, 慢性ス トレス感のある人と健康な人との間に HDT による 影響に有意な差は認められなかった。

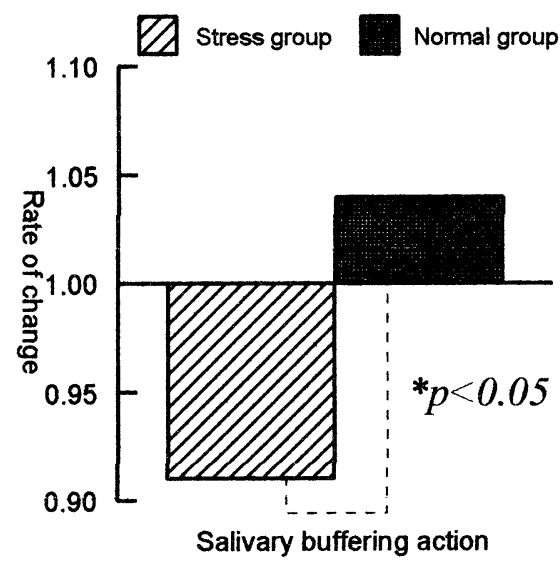

Fig. 2 Change rate of Salivary buffering action

考 察

本研究では, 唾夜中コルチゾール濃度では慢性ス トレス状態の人を同定できなかった。これは，本研 究におけるストレス群がストレスに適応しながら社 会生活を送っている人たちであったためだと考えら れ，「ストレス疾患」の病前検出の困難さを物語っ ている。しかしながら， $7^{\circ}$ HDT 影響下で慢性ス トレス状態の人たちと健康な人たちとに唾液緩衝能 の差が認められた。したがって，唾液緩衝能が自覚 されない身体的ストレッサー条件下で慢性ストレス 生理的指標になりうる可能性が示唆された。 
対処可能，不可能状慜における音楽の赫效果（2）

山本正平 (愛知諔徳大学コミュニケーション研究科)

清水 遵 （愛知淑徳大学コミュニケーション学部）

\section{【研究の目的】}

Holbrook ら (1990)の対症療法仮説や同質性仮説は音楽 の構造（テンポ等）や覚醒レベルの異なるストレス課題 を用いて得られた説であるが，ストレス対処の違いから 検証された研究は数少ない。本研究は昨年の学会発表を ふまえ, ストレス対処可能群の課題遂行の能力差, 罰の 強度, 課題遂行時間, 音楽聴取時間を考慮した統制を加 えたうえで，ストレス対処可能，対処不可能状態におけ る音楽のストレス軽減効果について検討した。

\section{【方法】}

『参加者】大学生, 大学院生 39 名（男性 5 名, 女性 34 名, 平均年齢 25.17 歳) が参加した。参加者はストレス 対処可能な課題遂行後, 音楽聴取する群 ( $\mathrm{C}-\mathrm{m}$ 群), 対処不 可能な課題遂行後, 音楽聴取する群(UC-m 群), 対処可能 な課題遂行後, 音楽聴取せず安静を保つ群 ( $\mathrm{C}-\mathrm{nm}$ 群), 対 処不可能な課題遂行後, 音楽聴取せず安静を保つ群 (UC-nm 群)の 4 群に分類された。

『指標】自律神経指標として心拍 $(\mathrm{HR})$, 平均血圧 (MBP), 圧反射感度 (BRS)を, 主観指標として気分 VAS（対語 24 項目)を用いた。HR と MBP は安静時から連続して測定し,

安静後, 課題後、音楽後にVAS を実施した。

【刺激と手続き】参加者は安静状態 (5 分) 後, 2 析以下の 加减算をPCにて 4 択解答した。全群とも計算課題遂行前 にPre Task として罰無し計算課題を遂行し(30 問)，その 成績に基づいてストレス対処可能群の制限時間を設定し た。また，ストレス対処可能群には不正解・制限時間超 過の場合, 罰としてビープ音が鳴り, ある回数までビー プ音が加算されると直径 $80 \mathrm{~cm}$ の風船が破裂した。対処不 可能群には対処可能群の結果を yoked させ, 課題成績に 関係なく罰が与えられた。計算課題遂行時間を約 15 分と し, その後の音楽聴取時間も約 15 分 (ローテンポ音楽 (60 〜100BPM) 3 曲) とした。

\section{【結果と考察】}

HR, MBP，BRS，主観気分值は(1)安静から課題における変 化量（安静時をベースラインとする）と(2)課題から音楽 または安静における変化量（課題時をベースラインとす る）として算出された。なお，主観気分変化量は快一不 快值と覚醒一眠気值の次元軸からなるべクトル内積値を
算出した。測定エラー等により, $\mathrm{HR}, \mathrm{MBP}, \mathrm{BRS}$ 変化量で は 5 名のデータが，主観気分変化量では 6 名のデータが 除外された。(1)と(2)においてそれぞれ2(音楽有・無) $\times$ 2 (ストレス対処可能・不可能) 分散分析にて 4 群を比 較した。

HR：(1)ではストレス対処可能・不可能の主効果が有意で あり $(F(1,30)=10.43, \quad p \times .01)$, 対処可能群が不可能群 より有意な上昇を示した。(2)では音楽有・無×ストレス 対処可能・不可能の交互作用が有意であり $(F(1$, 30) $=5.07, \quad p \ltimes .05), \mathrm{UC}-\mathrm{m}$ 群が $\mathrm{C}-\mathrm{m}$ 群, UC-nm群より有意 に高かった。すなわち, 対処不可能状態後の音楽聴取は HR の減少を妨げることが示唆された（図 1 )。 MBP，BRS : (1)，(2) において有意差がみられなかった。 主観気分 : (2)においてストレス対処可能・不可能の主効 果が有意であり $(F(1,29)=9.23, \quad p \times .01)$, 対処不可能 群の気分が対処可能群よりも課題後の状態（音楽・安静） に伴い大きく変化したことが示された。さらに快值と覚 醒值を検討したところ, 快值ではストレス対処可能・不 可能の主効果が有意であり $(F(1,29)=18.16, \quad p<.01)$, 対処不可能群の快值が対処可能群よりも大きかった。覚 醒值では音楽有・無の主効果が有意であり $(F(1$, $29)=7.98, \quad \not<.01)$, 安静群が音楽聴取群よりも低覚醒レ ベルを示した。一般に高覚醒状態後のローテンポ音楽聴 取は対症療法仮説を支持する結果であるが，本研究では ストレス対処不可能状態後の音楽聴取においてのみ覚醒 レベルが高い状態で維持され，対症療法仮説が支持され ないことを示唆した（図1・図2)。

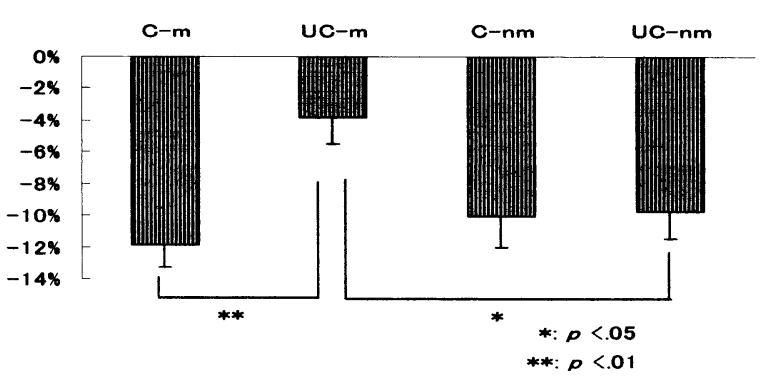

図 1：4群間の課題から音楽における $\mathrm{RR}$ 変化量

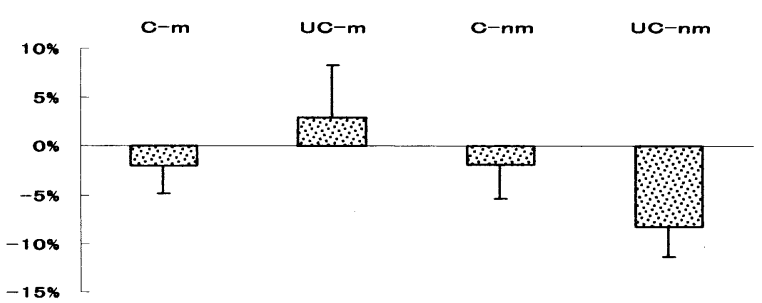

図 2：4群間の課題から音楽における MBP 変化量 


\section{規準化脈波容積を応用する新しい血管内皮機能検査} 一ストレスによる抑制と超音波標準法との一致度一
堀口 雅美 (札煶医科大学保健医療学部)
加藤 有一 (札沅医科大学医学部)
○田中 豪一 (札帨医科大学医学部)
松村 健太 (北海道大学大学院文学研究科・ 日本学術振興会特別研究員)
澤田 幸展 （机幌医科大学医学部）

\section{【目的】}

動脈硬化におおる最早期の生理的変化として血管 内皮機能が低下寸ることから，その簡便な評価方法を 開発する意義は大きい。血管内皮機能の標準検查法で は, 反応性充血 (reactive hyperemia：RH) 時の上腕動 脈もしくは橈骨動脈流量依存性血管拡張反応

(Flow-mediated dilation：FMI) を超音波画像分析に よって測定寸る。本研究は予備的研究として血管内皮 機能を規準化脈波容積 (normal ized pul se volume:NPV) の応用によって評価し FMD と比較した。左右第 2 指で 測定した NPV から指動脈トノメトリ (peripheral arterial tonometry : PAT)を算出し, PAT と\%FMD の相 関分析およびストレス課題負荷による変化を検討した。

\section{【方法】}

被験者：実験に関し同意の得られた，心血管系に既往 歴および現病歴のない健康な 20〜30 歳の男性 11 名。 ストレス課題負荷による変化では実験全期間を通して データの得られた 5 名を分析対象とした。

ストレス課題 : 6 分間の暗算課題を用いた。

FMDの測定および分析 : 安静仰臥位の被験者に対し駆 血用力フを左上腕に装着, 超音波診断装置 (UX-02 型, リオン, 東京) の探触子 UF-31 探触子 (15MHz) を左上 腕動脈の时窩に固定した。収縮期血圧に $60 \mathrm{mmHg}$ を加え た圧で駆血 5 分後, 駆血を解除しRH をさせ 180 秒間測 定した。血管径の画像は心電図と同期させ, 生体アン プ（1253A，NEC メディカルシステムズ，東京）を経由 し10枚の平均から1枚の画像になるよう設計されたプ ログラムで解析した。駆血前 120 秒間のうちの 51〜60 秒の血管径を基準に駆血解除後 51〜60 秒の搪張した 血管径を\%FMD とした。ストレス課題負荷の変化の検 討では対数変換を行った。

NPV の測定およびPAT の算出:脈波は光源を波長 $810 \mathrm{~nm}$ の発光ダイオード (L810-40K00, エビス電子, 大阪),
受光センサーをフォトダイオード $(\mathrm{HPI}-2464 \mathrm{R} 5$, 光電 子工業研究所, 東京)にし左右手第 2 指基節部に装着, 透過光量を自作の脈波増幅装置で測定した。脈波も FMD と同じ生体アンプを経由しサンプリングタイム 1ms, 16bit で $\mathrm{AD}$ 変換された。駆血前 120 秒間を基準 に RH 後の左右の NPV を求め, さらに左の NPV から右の $\mathrm{NPV}$ の差をPAT とし，1 分ごとに PAT の平均値を求め た。FMD との相関分析には駆血解除後 60〜 120秒のPAT を採用した。

手続き：ストレス課題負荷前 (安静時) にNPV とFMD を測定した後ストレス課題を実施し,課題終了 10 分後, 30 分後, 60 分後にRH 時の NPV と FMD を測定した。

デー夕分析: 安静時, 課題終了 10 分後, 30 分後, 60 分後のPAT と\%FMDの相関分析を行った。ストレス課題 負荷による変化では一元配置の分散分析を行い，有意 水準は 5\%とした。

\section{【結果および考察】}

PAT と\%FMDの相関分析について散布図をFig. 1 に示 した。 $\mathrm{r}^{2}=0.1029$ であった。

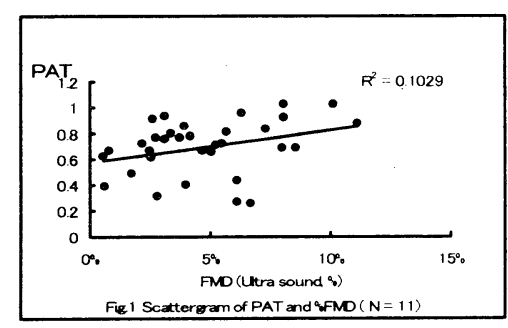

ストレス課題負荷によるPAT と FMD の変化をFig. 2 に示した。分散分析の結果, 有意差はなかった。

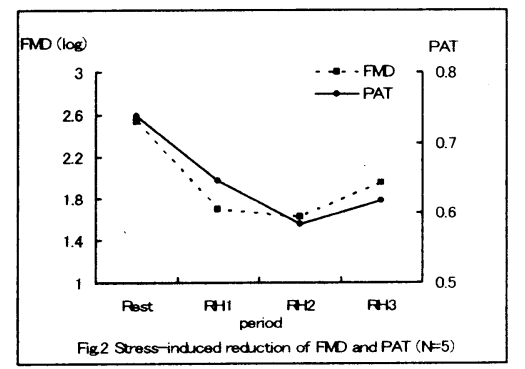

一般に RH による血管径拡張のピークは駆血解除後 60〜120 秒と言われている。今回，測定部位は手根部 と肘窩部であるがピークに達する時間を揃えて検討し たところ相関は低く，ストレス課題負荷により PAT, FMD いずれも低下したものの有意差はなかった。以上 のことから PAT を血管内皮機能検査に応用寸るには, RH 時の NPV の測定方法および被験者数という点からさ らなる検討が必要と考えられた。 


\section{裁決パタンに基づく陰性・陽性条件の比較}

○廣田 昭久 (科学警察研究所 情報科学第一研究室)

松田いづみ (科学警察研究所 情報科学第一研究室)

小川 時洋 (科学敕察研究所 情報科学第一研究室)

高澤 則美（江戸川大学社会学部）

ポリグラフ検査の基本原理は刺激の弁別である. 犯人しか知り得ない裁決情報と事件とは関係のな い非裁決情報とを呈示し, 各種生理反応の比較から 裁決情報の弁別の有無を判定する. しかし, 反応の 有無とその反応量の比較に基づく現在の検査方法 においては，裁決情報の弁別が生じていない場合， それを明確に識別することは難しい。

ポリグラフ検査の裁決質問時には, 皮虐電気活動 の増大, 皮虐血流量・筋肉部血液量や規準化脈波容 積（NPV）に反映される末梢血管抵抗の増加，血圧 の増加，心拍数の低下，呼吸運動の抑制等，一定の 反応変化方向を有した特徵的な生理反応パタン

（「裁決パタン」と以下述べる）が見られる。この 生理反応パタンの解析をもとにして, 裁決情報の弁 別の有無を識別する新たな解析方法を考案できる 可能性がある.そこで本研究においては，裁決パ夕 ンを基準として, 裁決情報が未知で弁別できない陰 性条件（無実群）と，裁決情報を有して弁別できる 陽性条件（犯人群）を設定して，両条件の反応パ夕 ンについて比較検討した。

\section{1. 方 法}

\section{【実験参加者】}

健常な大学生 35 名 (男 $15 \cdot$-女 20 , 平均年齢 20.5 歳) を犯人群19名と無実群16名に割り振った。

\section{【測定指標】}

瞬時心拍数 第II誘導法により心電図を計測し, 拍 動毎の值を求めた。

収縮期血圧 - 拡張期血圧 - 平均血圧 (MPB) 連続 血圧測定装置により拍動毎の各值を求めた。

皮膚コンダクタンス変化 右手第2 2 3指末節腹側部 に電極を付け，SCRとSCLを同時に計測した。

未梢皮膚血流量 レーザードップラー血流計によ り右手第 4 指末節腹側部より計測した。

NPV 発光部を右手小指爪付け根部に，受光部を末 節腹側部に装着し計測した。
前腕部組織血液量 $(\mathrm{Hb})$ レーザー組織血液酸素モ ニターにより，尺側手根屈筋，浅指屈筋，深指屈筋 部位の組織血液量を計測した。

呼吸曲線長 胸・腹部にバンド型センサーを装着し， 呼吸運動波形から，返答後10秒間の值を算出した。 コンプライアンス指標 指尖部での血管緊張度の 指標として，NPVを脈圧で除して求めた。 前腕血管抵抗指標 筋肉部位での血管抵抗の指標 として，MBPをHbで除して求めた。

\section{【手続】}

室内の貴金属を模擬的に窃取する犯人群と, 窃盗 は行わず部屋の中を観察するだけの無実群を設定 して, 各々の役割を演じさせた.その後, 隱し持っ た貴金属について質問する 6 項目（裁決 1 ・非裁決 5 ) からなるポリグラフ検査を実施した. 各項目は 30秒間隔で呈示し,全て「いいえ」と返答を求めた. 質問項目の呈示順序を変えて5セット実施した．最 初に呈示する非裁決項目は分析から除外した。

\section{2. 結果と考宍}

質問呈示後の 25 秒間について5秒毎の区間に分け， 生理指標毎に反応特性に基づいて分析対象とする 区間を定めて，指標毎に各区間で特定の1つの項目 とそれ以外の項目間の反応差について検討した。

犯人群においては真の裁決情報と非裁決情報間 で反応差について分析した場合，指標間平均で $28 \%$ の分析区間において有意差が得られたのに対し,無 実群では特定の 1 項目と他の項目間で分析を行っ た場合，いずれの指標においても有意な差が得られ る区間が少なく（指標間平均13\%）、有意差の得ら れた区間数から陽性・陰性条件の違いを推測できる 可能性が示唆された。

有意な差が得られた区間における反応が,裁決パ タンと一致する率を各指標毎に求めた結果, 犯人群 の真の裁決情報・非裁決情報間の差では，一致率は 指標間平均で $91 \%$ あったのに対し，無実群では平 均 $55 \%$ であり，陰性条件では一致する率と矛盾する 率がほぼ等しいことが明らかとなった。

また, 末梢血管抵抗の指標は裁決パタンとの一致 率が犯人群で高く，無実群では低くなり，陽性・陰 性条件を見極めるのに有効な指標であることが示 唆された。 
自律神経系反応の時系列的変化の数量化

$\begin{array}{rll}\text { ○松田 } & \text { いづみ } & \text { (科学警察研究所) } \\ \text { 廣田 } & \text { 昭久 } & \text { (科学警察研究所) } \\ \text { 小川 } & \text { 時洋 } & \text { (科学警察研究所) } \\ \text { 高澤 } & \text { 則美 } & \text { (江戸川大学社会学部) } \\ \text { 繁栘 } & \text { 算男 } & \text { (東京大学大学院総合文化研究科) }\end{array}$

\section{1. 目的}

ポリグラフ検查結果の統計的判定においては, 質問 呈示後一定時間の自律神経系指標の平均值が変数とし て用いられてきた。しかし，特に心臓血管系指標にお いては, 反応・回復という時間的な変化に生理学的背 景があり，判定に重要な情報が含まれていると考えら れる。このような時系列的変化の情報を統計的判定に 利用することにより，判定成績の向上が期待できる。 そこで本研究では，検查時の心臓血管系反応を典型的 な時系列変化との比較に基づいて判定する方法を考案 し，その効果を検討することを目的とした。

\section{2. 方法}

被䀫者 警察職員 33 名（男 30 名, 女3 名, 22-35歳) 湘定指標 第II誘導法により心電困を計測し，瞬時心 拍数(HR)を拍動毎に求めた。規準化脈波容積 (NPV) は発光部を右手小指爪付け根部に，受光部を末節腹側 部に装着して計測した。

手続き 被験者を陽性群(18 名)と陰性群(15 名)に分類 した。陽性群の被験者のみ，貴金属を模擬的に窃取し た。その後，窃取した貴金属について質問する6項目 からなるポリグラフ検查を実施した。各項目はランダ ムに音声呈示した。呈示順序を変えて 5 セット実施し た。セットの最初に呈示する項目は分析から除外した。 分析 各指標值はセット内で標準化した。各被験者の 各項目に対する反応として, 項目呈示後 5-15 s 間の平 均值と, 項目呈示後 $0-25 \mathrm{~s}$ 間を $5 \mathrm{~s}$ 毎に平均した計 5 点の時系列変化の 2 種類を切り出した。

時系列変化の数量化は, 多変量正規分布を用いて行 つた。判別対象とする被験者 1 名を除いた 32 名の被験 者の時系列変化について, 5 点の平均べクトル $\boldsymbol{\mu}$ と分 散共分散行列 $\Sigma$ を求めた。判別対象の被験者の時系列 変化と典型的な時系列変化との類似度として，その被 験者の時系列変化が平均 $\mu$,分散 $\Sigma$ の多変量正規分布 に従う確率を求めた。

各被験者が陽性・陰性群のどちらに属したのかを反
応から判定した。判定は, 各被験者の反応が陽性モデ ル（裁決・非裁決質問に対する反応は異なる分布に従 う）と陰性モデル（裁決・非裁決質問に対する反応は 同じ分布に従う）のどちらにより当てはまるかをモデ ル適合度指標 AIC で評価することにより行われた[1]。 分布の変数によって, (1) 1 指標の平均值を用いた判定, (2) 1 指標の時系列変化を用いた判定,(3) 2 指標の平均 值を用いた判定, (4) 2 指標の時系列変化を用いた判定, の 4 種の判定が行われた。分布の平均・分散は判定対 象外の被験者 32 名の反応から求めた。全ての被験者が 判定対象になるように 33 回繰り返し, 平均正判定率を 算出した。

\section{3.結果と考察}

(1)から(4)の判定による正判定率を Table 1.に示した。 時系列変化を用いた判定の方が，平均值を用いた判定 よりも高い判定成績を示した。

ポリグラフ検査時の心臟血管系反応は, 皮膚交感神 経活動の賦活による血圧増加反応が心拍出量の低下に よって相殺される，という心蔵血管系調節機序から説 明できる[2]。心臟血管系指標の時間的な変化はこの調 節過程の現れであるので，これを判定に取り入れたこ とで質問に対する生体の反応をより正確に捉えること ができ，判定成績が向上したと考えられる。

今後は, 被験者数を増やして本研究の結果を追試す るとともに, 時系列変化の個人差を考慮して判定を行 うため, 潜在クラス分析[3]の導入を検討する。また， 個人内で裁決・非裁決質問間の時系列変化の違いを検 討できるよう，分布のパラメータを個人のデータのみ から推定して判別を行う方法についても検討する。

Table 1. 正判定率

\begin{tabular}{ccccc}
\hline \multirow{2}{*}{ 用いた指標 } & \multicolumn{2}{c}{ 平均值 } & \multicolumn{2}{c}{ 時系列 } \\
& 陽性群 & 陰性群 & 陽性群 & 陰性群 \\
\hline 1 指標(HR) & .611 & .600 & .722 & .867 \\
2指標(HR, NPV) & .611 & .667 & .833 & .800 \\
\hline
\end{tabular}

\section{引用文禁}

[1] Adachi, K. (1995). Statistical classification proadures for polygraph tests of guilty knowledge Behaviormetrika 22, 49-66.

[2] 廣田・松田・高澤 (2004). ポリグラフ検查時に生起する血圧変化 の前期・後期成分とその機序. 生理心理学と精神生理学, $22,110$. [3] Matsuda, I., Hirota A., Ogawa T., Takasawa N., Shigemasu, K. (in press). A new discrimination method for the Concealed Information Test using pretest data and withinindividual comparisons Biological Psychology 


\section{虚偽検出場面における社会的要因の影響}

○大島 和臣 (埼玉県警科学捜査研究所)

長野 祐一郎, 岩田 真由美

(文京学院大学人間学部心理学科)

<目的 $>$ 心拍数. 皮膚電位. 呼吸等は, 対人要因の影 響により大きく変化することが知られている。検査者と 被験者が面接を行った上,裁決質問を決定し,検査を 実施する虚偽検出検查は対人要因の関与する場面と 考えられる。

しかし,対人要因を統制する困難さもあり,対人要因 により虚偽検出時の生理反応がどのような影響を受け ているのかは未だよく知られていない。

本研究では,二人の検查者により,検査者の服装,検 査者と被験者の位置,教示の口調を操作し,緊張条件と, 非緊張条件を設け,両条件における生体反応の変化を 検討した。

<方法>被験者:女子大学生 18 名 (平均年齢 21.3 歳, $\mathrm{SD}=1.78)$ 。

手続き: 実験者が見ていない別室で模擬窃盗を実施し た。事前に異なる貴金属を入れた封筒を5つ用意し,好 きな封筒を 1 つだけ選んで開封し中身を確認した後, その封筒ごと隠し持たせた。動機付けを高めるため「嘘 の露見と知能や感情のコントロールとは関係が深いと いう誤った情報を与えた後,安静期をはさみながら 2 つ の検查条件において隠し持った貴金属名について質 問する虚偽検出検査を行った。なお検査条件におけ る緊張の度合いを測るため,一般感情尺度を用いた。 検査条件:緊張条件はスーツとネクタイを着用し,被験 者の目の前に立ち,硬く厳しい口調と態度を心がけた。 非緊張条件では普段着で,被験者に対し 90 度の角度 に座り,軟らかく優しい口調と態度を心がけた。

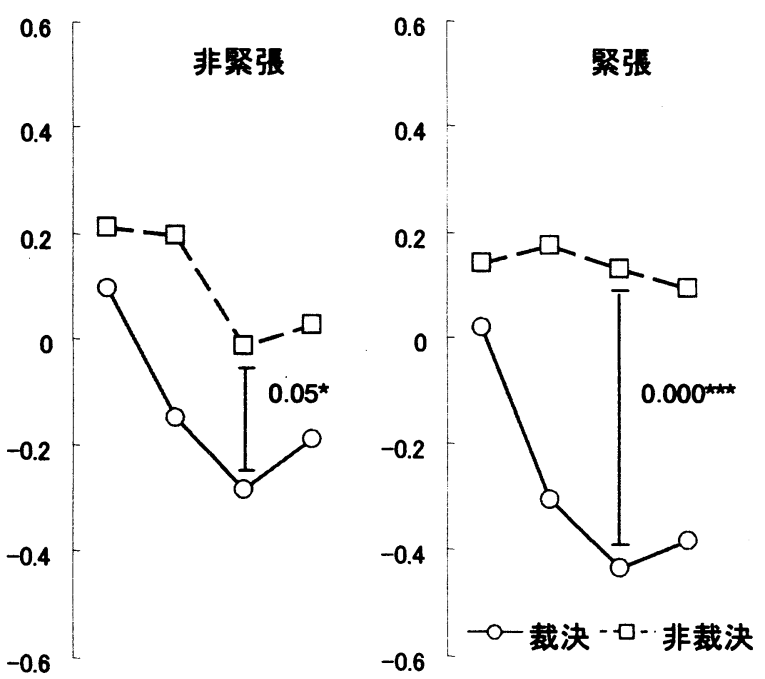

Fig.1 各区間におけるHRの平均檑準得点
生理指標: ECG (胸部) から心拍数 (HR)を算出,トノメ リ法による血圧波形 (手首) から収縮期血圧 (SBP) 拡張 期血圧(DBP)を算出,さらに血流量(右手ひとさし指,中 指)，呼吸 (腹部)，SPR（右手母指球）を測定した。

<結果と考察>緊張条件において非緊張条件よりも 不快感情の増大,安静感情の减少方向の変化が有意 であり,その結果,各条件は,適切に設定された事が明ら かになった。

HR と SPR は先行研究 (廣田ら,2003) と同様の傾向 を示した。さらに,非緊張・緊張条件間に差が認められ， 裁決・非裁決質問間の差は,緊張条件においてより明 確なものとなった。実験時間が長いため,非緊張条件 では,後半に覚醒水準が下がり,裁決・非裁決質問間の 差がやや不明確になったのに対し，緊張条件では覚醒 水準が一貫して高く維持されたため裁決・非裁決質問 間のコントラストが高く維持されたと考えられた。

SBP に関しては,緊張条件においてのみ,裁決・非裁 決質問間に有意な差が認められた。これらはいずれも， 先行研究と一部異なる結果であった。SBP に関しては, 緊張喚起が十分でないと,裁決・非裁決質問間に明確 な差が出にくくなる可能性が示唆された。

血流量に関しては,非緊張条件においてのみ,裁決・ 非裁決質問間に有意な差が認められた。実験期間が 2月〜3月であり,もともと血流量が低く維持された状態 であった。そのため,質問時の血流量低下が生じにくく, 裁決・非裁決質問間の差が明確にならなかった可能 性が考えられた。

対人要因の操作による緊張の増大は,高い覚醒状態 の維持を介し,SPR における裁決・非裁決質問間の差 をより明確なものにする可能性が示された。一方で,高 い緊張状態は指先の血流を減少させ,血流による虚偽 検出を難しくする可能性が示された。

結果,各指標の特質を理解したうえで,適切な対人緊張 状態の維持が重要であると考えられた。

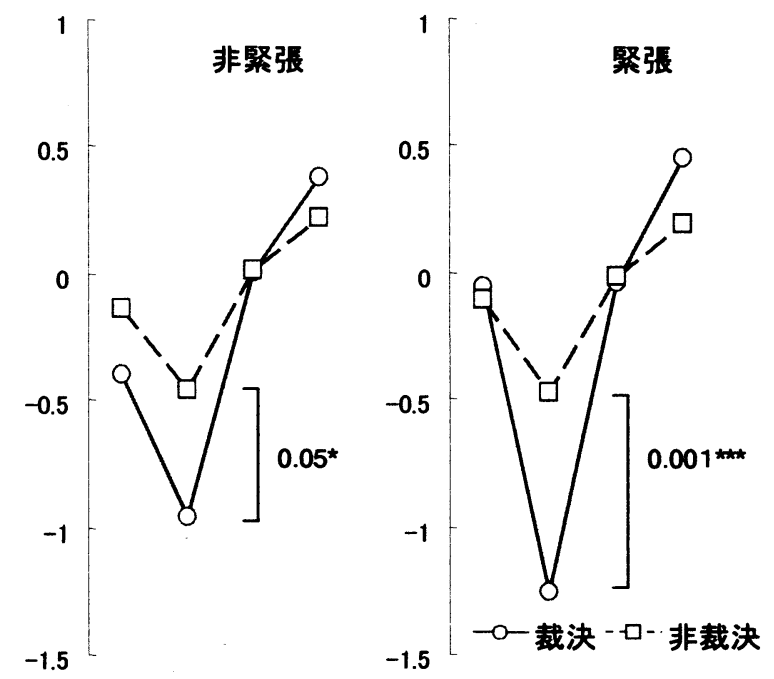

Fig.2 各区間におけるSPRの平均標準得点 


\section{虚偽検出検查における情報の既知性と} 動機づけについての検討

$\bigcirc$ 奥野 拓弘 (三重県警察本部刑事部科学捜査研究所)

小林 孝寛 (京都府警察本部刑事部科学捜査研究所)

藤井 正史 (岐皁県警察本部刑事部科学捜査研究所)

\section{【目的】}

本研究では，既知性および検出回避の動機づけが与え られた項目 (虚偽項目)，既知性のみが与えられた項目 (再 認項目),さらに複数の非裁决項目を加えて質問表を構成 し，心臟血管系の指標である心拍数（HR）と規準化脈波 容積（NPV）について検討した。なお，奥野ら（2005） は，皮膚コンダクタンス反応（SCR）と呼吸について同 様に検討しており，本研究はその継続である。

【方法】

参加者: 成人 18 名 (男性 8 名·女性 10 名, 平均 33.1 歳 $S D=8.46)$

装置：ティアック株式会社製ポリグラフ装置（PTH-347） で規準化脈波容積および心拍数を測定し，A/D 変換して パーソナルコンピュータへ記録した。

刺激：ロシア文字

手続き： 5 種類の刺激から任意に 1 つを選択，記憶する 作業を 2 回繰り返させた後，一方についてのみ，検出回 避の動機づけを与える教示をした。動機づけを与えた刺 激を虚偽項目，既知性のみの刺激を再認項目とした。こ の 2 項目に，無関係な 3 項目（非裁決項目）及び緩衝項 目を加えた 1 セット 6 項目からなる虚偽検出検查 (GKT) を 5 セット実施した。各セットの刺激呈示順序はカウン ターバランスした。刺激はモニタ呈示し, 呈示時間は $5 \mathrm{~s}$, 呈示間隔は $30 \mathrm{~s}$ 以上とした。返答は求めず，刺激呈示毎 に左手に持たせたボタンを押すよう教示した。 結果の分析：HR, NPV ともに, $1 \mathrm{kHz}$ のサンプリングデ 一夕から，緩衝項目を除く 5 項目の刺激呈示開始後 30s 間のデータについて，1s 毎に平均反忘量を求めた。各セ ット内で標準化し, $1 \mathrm{~s}$ 毎の標準得点 (z-score) を算出し,

5 セットの平均值を求めた。そして, 各刺激呈示開始時 から 20s 間を， $5 \mathrm{~s}$ 毎の 4 つの分析区間（ブロック）に分 けた。分析は，項目（3）×ブロック（4）の2 要因分散 分析を実施し，多重比較にはライアン法を用いた。

\section{【結果】}

各ブロック毎の項目別平均值を Figure1，2 にそれぞれ 示した。なお，NPVについては，全体的にノイズが頻発
した 3 名を分析から除外した。

分散分析の結果, HR は項目の主効果 $(F(2,34)=15.54$, $p<.001)$ 及び交互作用 $(F(6,102)=2.29, p<.05)$ が有意で あった。多重比較の結果，虚偽項目と再認項目，および 虚偽項目と非裁決項目に 5\%水準で有意差がみられた。 また，各ブロックにおける項目の単純主効果が有意であ った。 NPVは，ブロックの主効果 $(F(3,42)=3.06, p<.05)$ のみが有意であった。多重比較の結果，ブロック 2 と 4 に 10\%水準で有意差傾向がみられた。

\section{【考察】}

HR は，再認項目と非裁决項目に対して虚偽項目が有 意に低く，再認項目と非裁决項目は有意差がみられなか った。これは奥野ら（2005）のSCR や呼吸の結果と同様 で，虚偽項目と再認項目を同一七ット内で呈示すると， 虚偽項目に対する反応のみがみられることが示唆された。 したがって，虚偽検出検査の成績については，情報の既 知性だけでなく, 動機づけの影響が大きいと考えられる。

なお，NPVについては項目の主効果がみられなかった が，虚偽項目に対する反応が各ブロックで最も低下して おり, 分析対象者数の不足が影響している可能性もあり， 今後の再検討が必要と考えられる。
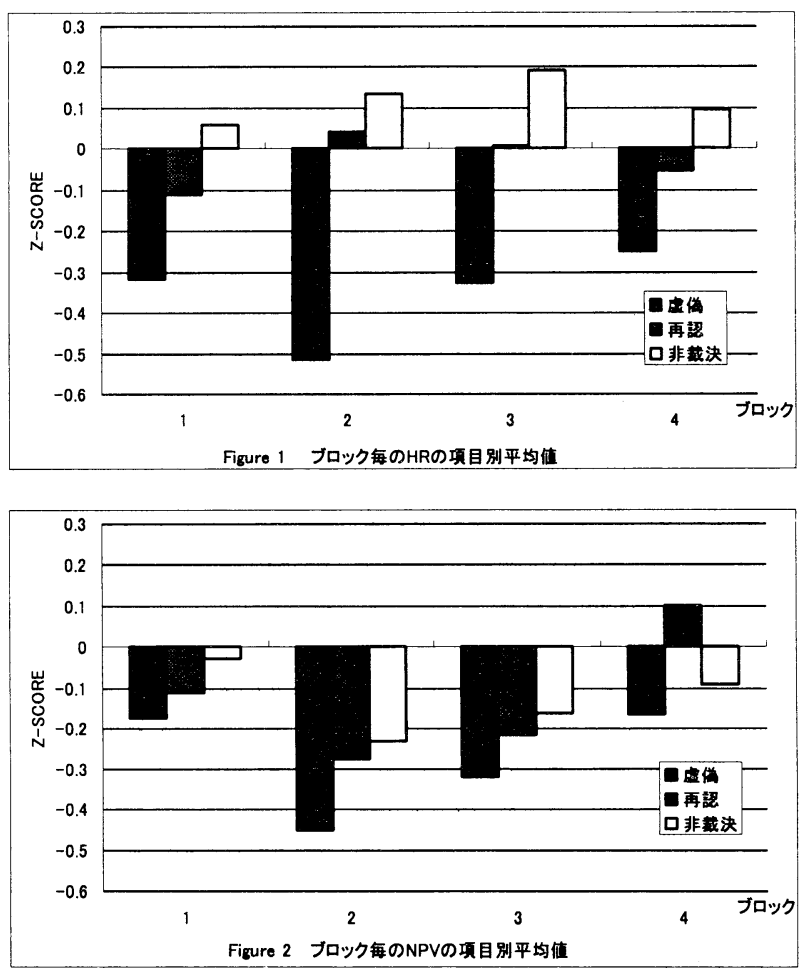

【文献】

奥野・小林・藤井 (2005). 日本心理学会第 69 回大会発 表論文集, 402. 


\section{カウンティング・ストループ課題を用いた虚俪検出}

$\bigcirc$ 大塚 拓朗 (兵庫県警察本部刑事部科学捜查研究所)

藤原 宏行 (兵庫県警察本部刑事部科学捜査研究所)

水谷 充良（兵庫県警察本部刑事部科学捜查研究所）

八木 昭宏 (関西学院大学文学部総合心理学科)

\section{【はじめに】}

虚偽検出検査時にfMRI を測定した実験において前部帯 状皮質 (Anterior Cingulate Cortex, ACC) の活性化が 報告されている。この前部帯状皮質は実務虚偽検出検査 で測定される自律系生理指標の働きに密接に関係してい る。そこで, 本研究では前部帯状皮質の機能研究で有効 性が示されたカウンティング・ストループ課題 (Bush et al. , 1998;以下 cStroop 課題とする）を用いて, 瞳孔反忘 を指標とした虚偽検出検査を実施した。Whalen et al. , (1998) は認知的な干渉がある cStroop 課題と情動語 を用いたエモーショナル・カウンティング・ストループ 課題（以下 ecStroop 課題とする）では前部帯状皮質の異 なる部位が活性化することを報告している。このことよ り，本研究において，犯罪に関わる用語 (裁決語) の再 認が認知的な要因に影響されるならば, cStroop 課題時に 類似した反応が, 情動的な要因が影響されるならば, ecStroop 課題時に類似した反応が見られることが予測さ れた。

\section{【方法】}

実験参加者 男性 4 名, 女性 1 名

課題と手続き 実験参加者には, 横一列に並んだ $1 \sim 4$ の各数字 $5 つ$ から構成される文字列（一行から四行）の 行数を数えさせる cStroop 課題 (NC 課題) と, 横一列に 並んだ 4 種類（雑誌・新聞・小説・殺人）・5単語から構 成される文字列（一行から四行）の行数を数えさせる ecStroop 課題（EC 課題）を行わせた。その後, 実験参加 者には模擬犯罪を行わせ，窃取したモノを含めた 4 種の 単語 (家具, 財布, 書類, 宝石) から構成されるカウン ティング課題 (GC 課題) を行った。また, 実験参加者に は窃取したモノが含まれない 4 種の単語（クマ, ゾウ, トラ, ブタ）から構成されるカウンティング課題（IC 課 題）も実施した。刺激は注視点 $500 \mathrm{~ms}$ 後, $1000 \mathrm{~ms}$ 間呈示 され, ITI は平均 $1500 \mathrm{~ms}$ であった。各課題は 1 単語（数 字）列が各 6 試行と実験参加者に反応を求めないブラン ク刺激が呈示される 32 試行の合計 128 試行で構成された。 $\mathrm{NC}$ 課題においては構成数字と異なる行数が呈示される試
行, EC 課題では情動語 (殺人) が呈示される試行, GC 課 題では裁決語が呈示される試行を干渉条件とし, それ以 外の試行を非干渉条件, ブランク条件とした。 睲孔測定及び処理

実験参加者の左眼睲孔をサンプリング周波数 $60 \mathrm{~Hz}$ で記 録をし, 各試行刺激呈示前 $500 \mathrm{~ms}$ 前をべースラインとし 加算平均処理を行った。アーティファクト（瞬目等）が 混入した試行は分析から除外した。刺激呈示後 $1000 \mathrm{~ms}$ 間 のピーク值を睹孔反応として実験参加者毎に算出した。

\section{【結果及び考察】}

反応時間 $\mathrm{NC}, \mathrm{EC}$ 両課題共に干渉・非干渉条件の間に統 計的な差は見られなかった。GC 課題においても干渉（裁 決語）条件と非干渉 (非裁決語) 条件間に統計的な差は 見られなかった。また, GC 課題と IC 課題の間にも有意差 は見られなかった。

瞳孔反応 $\mathrm{NC}$ 課題及び $\mathrm{EC}$ 課題において 3 水準 (干渉・非 干渉・ブランク条件) の ANOVA を行ったところ, 条件の 主効果が見られた $(F(2,8)=6.34, \not \subset .05$ 及び $F$ $(2,8)=6.34, \not \subset .05)$ 。 HSD検定の結果, ブランク条件と他 の 2 条件間に有意な差が見られたが, 干渉の有無による 差はなかった。本研究の目的である模擬犯罪で窃取した 用語 (裁決語) が含まれた GC 課題 (Fig. 1参照) 及び IC 課題も同様の結果であった $(F(2,8)=6.39, \not \prec .05$ 及び $F$ $(2,8)=6.39, \not \propto .05)$ 。

本研究では各課題において条件間の差は見られなかっ た。先行研究においてRTに条件差が確認されていること より，今後の継続的実験により条件差は期待される。生 理反応については，今後，他の自律系指標の測定も考慮 していく必要が考えられた。また虚偽検出の研究パラダ イムとしてのcStroop 課題及びecStroop 課題には期待さ れるものが大きいものと考えられた。

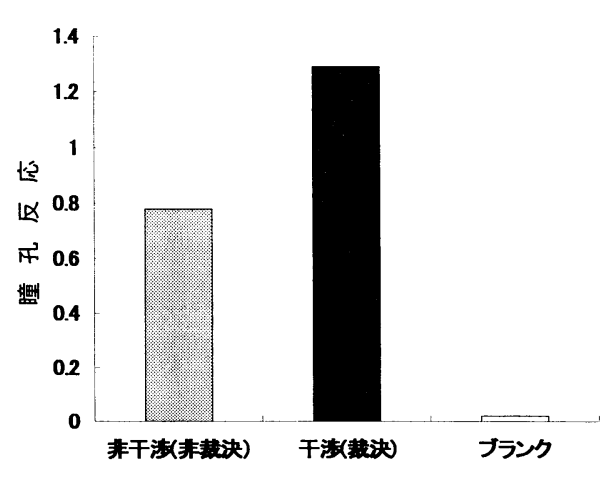

Fig.1 GC課題における平均瞳孔反応 


\section{虚偽検出における神経系の指標の検討 一中枢神経系と自律神経系の同時導出から一}

○岸 靖亮 (北海道大学大学院教育学研究科) 藤澤 清 （仁愛大学人間学部）

目的

これまでの虚偽検出検査の研究から, 様々な生理指 標の有効性が検討されてきた。しかし，各生理指標は 同時導出して検討されていないため，その指標の有効 性は直接的に比較検討されていない。そこで本実験で は, 犯人のみが刺激に文脈を構築出来るように設定し, 中枢神経系と自律神経系の生理指標を同時導出寸るこ とで, 情報処理過程と情動の変化を総合的に判断し, 指標の一般性を検討する目的で行った。

\section{方法}

被験者: 大学生 14 名(男性 2 名、女性 12 名)で, 平均 年齢は 21 歳(年齢範囲 20〜22)であった。

実験条件：模擬窃盗を行う有罪条件, 模擬突盗事件に は関わらない無罪条件の 2 条件を設定した。

刺激 : Session1 では，窃盗の対象となった可能性のあ る 5 種類の品物を, Session2では, 窃盗した者が触れ た可能性のある 5 種類のバッグを，写真による視覚刺 激として呈示した。最初に黒い画面を 5 秒間呈示した 後, Session1では「犯人が盗んだのは」, Session2 で は「犯人が触ったバッグは」という文章を 10 秒間呈 示し, それ以降は 写真刺激を呈示時間 1 秒間, 呈示 間隔 20 秒間の設定で，25 試行呈示した。

記録指標：EEG，SPR，を測定した。EEG は，国際 10-20法に従い, Fz，Cz，Pzから，両耳梁結合を基 準として導出した。SPR は, 皮膚表面電極を用いて, 探査電極を左手小指球におき, 基淮電極を左手前腕屈 側部において導出した。

実験手続き: 被験者は, クジによって条件分けされた 後, 条件に対応した課題を行った。課題終了直後に, 有罪条件の被験者から虚偽検出検査を受けた。

\section{結果}

脳波に関して：有罪条件では，両セッションともに， 裁決項目に対し P300, 非裁決項目に対し N400 の生 起がみられた。無罪条件では, 両セッション, どの刺 激にも特異な成分は得られなかった。Figure1 は, Session 1 における, 両条件の非裁決項目に対する脳 波の総加算平均波形を示している。有罪条件では
N400 がみられたが，無罪条件ではみられなかった。 皮膚電位反応に関して : 有罪条件では, 両セッション ともに，裁決項目に対して大きな振幅が生起した。無 罪条件は, 両セッションともに, 裁決項目に対して小 さな振幅を示した。裁決項目に対する SPR 波形の振 幅に関して，条件間で対応のある $t$ 検定を行ったとこ 万, 有意な差が認められた $(t(12)=7 。 507, p<。 001)$ 。 Figure2 は, Session1における, 有罪条件の刺激に対 する SPR の総加算平均波形を示している。裁決項目 に対して大きな振幅の陰陽二相性波が得られた。 呼吸に関して: Session 1 では, 有罪条件は減少傾向 を示し，無罪条件は変化を示さなかった。Session 2 では条件間に違いが無く,両条件ともに平坦であった。 心拍に関して：どちらの条件も, 両セッションで減速 方向への変化を示し，明瞭な違いは得られなかった。

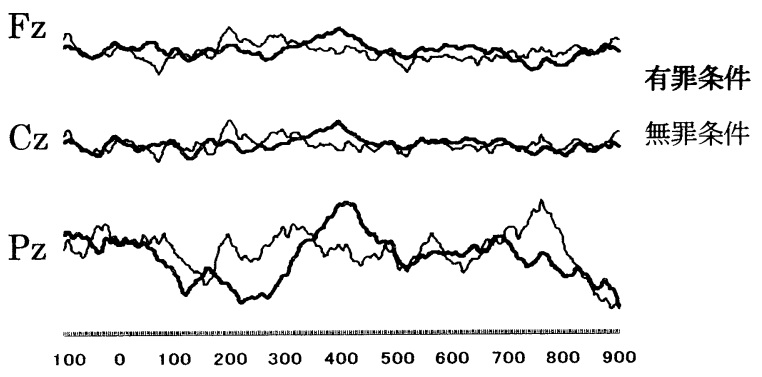

Figure 1。Session 1 における, 両条件の非裁決項目に対する脳波

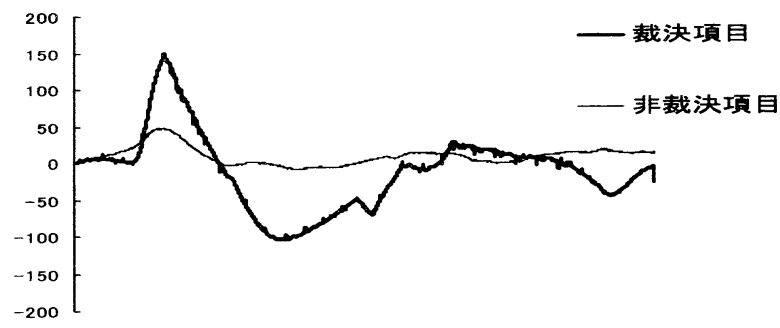

Figure 2 。 Session 1 における，有罪条件の刺激に対するSPR 波形 考察

脳波では，有罪条件にだけ P300 と N400 がみられ た。これは，犯人のみが刺激に対し事件に関する情報 としての特別な意味を見出し，文脈を構築したことを 示している。よって, 情動や環境の影響を受けにくく, 記憶のみを探れる脳波は，有効な指標と考えられる。

皮膚電位反応では，条件間で波形に明瞭な違いがみ られたことから，本実験では指標の有効性がみられた と言える。

刺激を事件に関する情報として処理するのと共に， 情動にも不安や焦燥と思われる反応が同時にみられた ことから，その指標の一般性が検証された。 
行為時の感情喚起が Concealed Information Testに 及ぼす影響

\section{一ERP および末梢指標の同時計測によるアプローチー}

○大杉朱美 (名古屋大学大学院㻴境学研究科)

大平 英樹 (名古屋大学大学院環境学研究科)

CIT (Concealed Information Test) は, 裁決刺激を有 意味な情報として処理する認知的な活動により可能に なる検査である。しかし近年，それまで軽視されがち であった CIT に関わる情動要因が注目されつつある.

これまで行為時の覚醒が高い被験者ほど裁決刺激に対 する P300 が増大することが示されているが, 覚醒度の 違いを被験者内で操作した研究はない。そこで本実験 では, 模擬犯罪課題として覚醒度の異なる 2 種類の行 為を課し, その後の CIT において, それら 2 種類の行 為に関わる裁決刺激を同じ系列内に配置した。覚醒の 操作の妥当性を証明するため, 実験通して末梢系指標 である心拍 (HR) および皮膚電気活動 (EDA) を測定する ことで, 中枢と末梢の両側面から CIT メカニズムの検 討を試みた。

\section{方法}

実験参加者 大学生 14 名 (男性 5 名, 女性 9 名)

手続き 模擬犯罪課題実施前に, あらかじめ参加者は 無罪の状態での CIT を受けた。ここでは「はさみ」が 呈示されたら左ボタンを, それ以外の画像が呈示され たら右ボタンをできるだけ早く正確に押すよう求めら れていた。その後, 2 種類の模擬犯罪課題が被験者間 でランダムな順に実施された。彼らは刃物名が書かれ た 5 枚の封筒の中からひとつ選び, 指定された刃物で かごの中に入った画像を 5 分間刺し続けるよう指示さ れた。高覚醒課題の画像は赤ちゃん人形の写真であり, 低覚醒課題の画像は果物の写真であった。最後に, 再 びCIT が実施された。ここでも同様に，単に「はさみ」 が呈示されたら左ボタンを, それ以外の画像が呈示さ れたら右ボタンをできるだけ早く正確に押すよう求め た。それぞれの課題間には 5 分間の安静時間が設けら れ, さらに各 CIT 後には, 呈示されていた 6 種類の刺 激それぞれに対し, 画像評定が求められ, 感情価と覚 醒度について 9 段階で評定された。

刺激 刃物 6 種の画像（はさみ, 包丁, カッター, 鎌, アイスピック，のこぎり)。標的刺激にはさみの画像, 高裁決刺激に参加者が高覚醒課題で使用した凶器の画 像, 低裁決刺激には低覚醒課題で用いられた画像, 非 裁決刺激にそれ以外の刃物 3 種の画像を用いた。刺激
はディスプレイに視覚呈示し, 呈示時間は $600 \mathrm{~ms}$, 刺 激間間隔 $5400 \mathrm{~ms}$ であった。刺激呈示は各ブロック 90 回とし, 各刺激をランダムに 15 回ずつ呈示した。合計 で 2 ブロック 180 回呈示された。

指標 事象関連電位 $(\mathrm{ERP})$ および心拍 $(\mathrm{HR})$, 皮膚電気活 動 (EDA)が BIOPAC (BIOPAC Systems, Inc.)により測定 された。ERP は国際 10-20 法により, 鼻尖を基準とし て頭皮上 3 部位 $(\mathrm{Fz}, \mathrm{Cz}, \mathrm{Pz})$ に脳波導出用の電極を装着 した. 脳波へのノイズ混入を監視するため, 瞬目を左 眼窩上下部から EOG 法により測定した.

\section{結果と考察}

実験操作チェック まず画像評定について, 各刺激 (4) $\times$ 実施時期 (2)の 2 要因の分散分析を行った。感情価で は有意差がなかった一方, 覚醒度では刺激と実施時期 の交互作用が有意であり $(p<.01)$, 課題後, 高裁決刺激 と低裁決刺激に対する覚醒が非裁決刺激より有意に高 まったことがわかった。また高裁決刺激のみ, 課題前 と課題後の評定に有意差がみられた。HR および SCLに ついて, 各課題を 1 分毎に区切り, ベースラインとそ れら平均値を比較したところ, 課題開始 1 分間で有意 に HR が上昇し, 上昇の程度は低覚醒課題より高覚醒課 題で大きいことがわかった ( $p$. 01)。SCLに関しては刺 激の主効果が有意であり, 高覚醒課題中は低覚醒課題 中より有意に SCL が増大していた $(p \times .05)$ 。

ERP 課題前 CIT と課題後 CIT の Pz における ERP 波形 をそれぞれFigure. 1, Figure. 2 に示した。各刺激への 反応について頂点振幅を比較したところ, 課題前 CIT では標的刺激に対してのみ有意に振幅が大きかった $(p \ltimes .01)$ 。課題後 CIT では, 課題前 CIT 同様に標的で最 も大きな振幅が得られたが, Pzにおいて, 高裁決刺激 が有意に低裁決刺激より大きく，またそれらいずれも 非裁決刺激より大きいという結果が示された $(p<.01)$ 。 CIT 中の HR およびEDA についても今後解析を進め, 更 なる検討を行う予定である. 非裁決

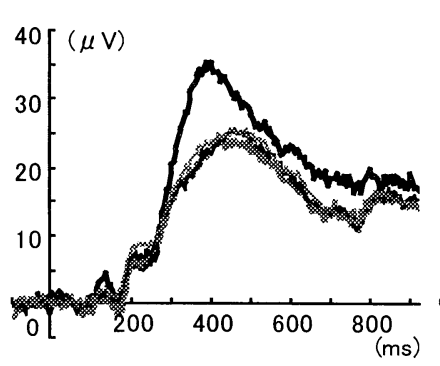

Figure. 1 課題前 CIT $の$ ERP

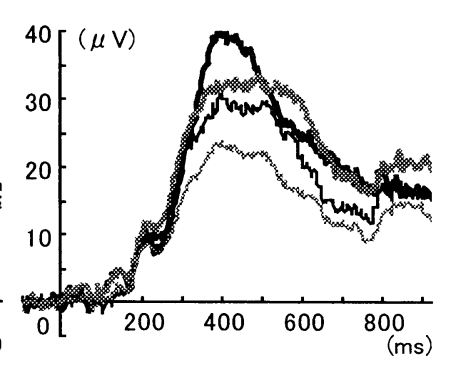

Figure. 2 課題後 CIT の ERP 


\section{虚偽検出に関する基礎的研究 ーソースモニタリング ERP の検討一 \\ ○大島 健治 (岡山県警察本部科学捜查研究所) \\ 宮谷 真人 (広島大学教育学研究科)}

虚偽検出検査では，犯罪情報に関する記憶の有無を 検出する。そのため，有罪者と報道等で公表された犯 罪情報を有する無罪者とを弁別することは困難である。 本研究では，ソースモニタリング課題で報告された ERP 知見の応用を試み, 両者の弁別が可能であるかど うかを探るための基礎研究をおこなった。併せて，ソ 一スモニタリング課題によって有罪者を検出できるか どうかについても検討した。

ソースモニタリングは符号化情報の起源に関して 想起を求める課題である。そして，符号化時の運動情 報の有無は前頭-中央部位の ERP に反映される可能性 が示唆されている $[1]$ 。本研究では運動情報を伴う学習 課題と伴わない学習課題を設定し, 両課題間で比較し た。また, 虚偽検出検查への応用を想定し, 各課題で 学習する項目を 1 種類とした。

\section{【方 法】}

実験参加者: 大学生 12 名 (男 6 名, 女 6名, 20-34 歳)。 学習課題 : 運動情報を伴う課題(Perform 課題) と伴わ ない課題 (Photo 課題, Imagine 課題) 33 種類を設定し た。Perform課題では装飾品を身につけさせた。Photo 課題では装飾品のカラー写真をディスプレイ上に呈示 し，観察させた。Imagine 課題ではディスプレイ上の 正方形の枠内に装飾品のイメージを生成させた。各課 題の実施に先行して，学習項目を示寸単語をディスプ レイ上に呈示した。

刺激 : 装飾品名のテスト単語 6 種類で構成し, ディス プレイ上に呈示した。3 種類は学習項目であり, 残り の 3 種類は未学習項目とした。呈示時間は $300 \mathrm{~ms}$ ，呈 示間隔は 10 秒であった。各刺激 60 試行おこない，総 試行回数は 360 回であった。

手続き: 参加者は 3 種類の学習課題を実行した直後に, 再認課題を行った。ディスプレイ上に呈示されたテス 卜単語に対してボタン押し反応をさせ，学習時の課題 種別(Perform/Photo/Imagine)または未学習(New) 項目 であるかの判断を求めた。

ERP 測定: 頭皮上 19 部位から鼻尖を基準として記録し た（バンドバスフィルタ $0.03-30 \mathrm{~Hz}$ ，サンプリング周
波数 $1,000 \mathrm{~Hz})$ 。アーティファクトおよび誤反応試行を 除き, 刺激呈示前 $100 \mathrm{~ms}$ から刺激オンセット後 $2,000 \mathrm{~ms}$ までの区間を加算平均した。

\section{【結果および考察】}

Figure 1 に総加算平均 ERP 波形を示した。未学習 (New) 項目と比較して, Perform 項目および Imagine 項 目には刺激オンセット後 300-500ms に陽性電位が出現 した。したがって，本パラダイムを用いて学習項目を 検出できることが確認できた。

一方，Perform 項目と Photo/Imagine 両課題との間 で有意差はみられなかった。先行研究[1]の知見とは異 なり, 前頭一中心部位で符号化時の運動情報の有無を弁 別することはできなかった。ただし，刺激オンセット 後 $800 \mathrm{~ms}$ 以降に Imagine 項目の電位が Photo 項目と比 較して陽性にシフトした。この結果から, 学習時に視 覚情報が付随していたかどうかを弁別しうる可能性は 示唆された。

本研究の反応時間が短かったことや，テスト単語と 反応ボタンとを連合させたという内省報告から, 検索 方略または反応方略が先行研究とは相違していた可能 性が考えられた。今後は，課題対処方略を統制する手 続きの開発が必要である。

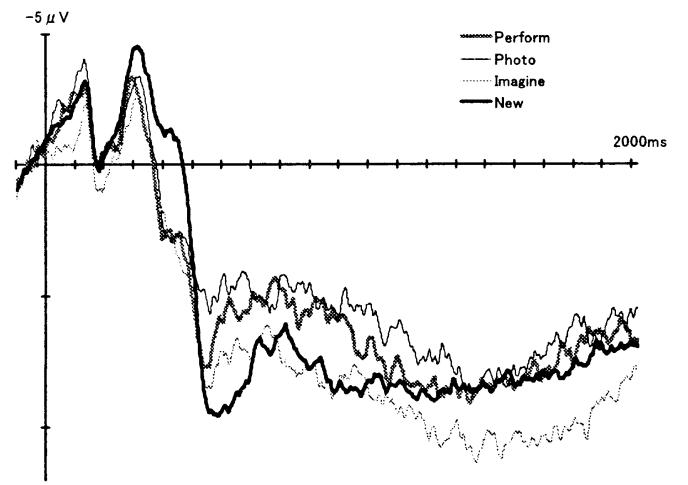

Figure 1． 前頭部 $(\mathrm{Fz})$ における総加算平均波形 $(\mathrm{N}=12)$

\section{【引用文献】}

[1]Senkfor, A. J. , Van Petten, C. , \& Kutas, M. (2002). J. Cogn. Neurosci. , 14, 402-419.

【謝辞】

本研究は平成 17 年度科学研究費補助金 (課題番号 17905009）の助成を受けておこなった。また，本研究 の実施にあたり, 広島大学教育学研究科梨和ひとみさ ん，白石舞衣子さん，徳永智子さんの協力を得た。 
P300 による虚偽検出における外向性一内向性の影響

平 伸二（福山大学 人間文化学部）

GKT の検出理論として, 生理反応に影響を与える被 検者要因に関する研究は多い. 被検者要因として研究 が多いのは, 不安 (Giesen \& Rollison, 1980), サイコ パス(Balloun \& Holmes, 1979; Miller \& Rosenfeld, 2004; Verschuere, 2004), 向性次元などのパーソナリ ティ要因である. 特に, 向性次元は研究が多い反面, 外向性の優位性(Steller, Haener t \& Eiselt, 1987), 内向性の優位性 (Gudj ons son, 1982), 向性次元では差 がない(Iacono, Boisvenu \& Fleming, 1984)という一 貫性のない結果が得られている.これまでの向性次元 による研究は, 皮膚電気活動を指標としたものである が, 本研究では中枢指標である P 300 を用いて外向性一 内向性の影響を検討した.

\section{方 法}

参加者 86 名の大学生にパーソナリティの 5 因子人格 検查（日本版 NE0－PI-R）を実施した結果, 外向性得 点の平均値は 102.0 点 $(S D=24.6)$ となった. この中 から, 内向性群 10 名 $(M=21.0$ 歳, $S D=1.0)$, 外向性 群 10 名（ $M=21.1$ 歳, $S D=1.04 ）$ の協力を得た. 内向 性群の平均得点は 71.0 点 $(S D=6.0)$, 外向性群の平均 得点は 137.6 点 $(S D=12.4)$ であった.

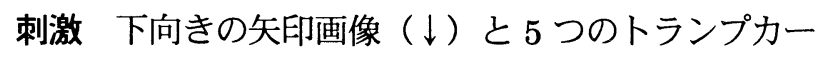
ド画像 $(2,4,6,8,10) を, 1 \mathrm{~m}$ 離れたディスプレイ上に視 野角 $5^{\circ}$ の画像刺激として呈示した. 呈示時間は $300 \mathrm{~ms}$, 呈示間隔は $1500 \mathrm{~ms}$ とした. 矢印画像が標的 刺激, カードの 2 が裁決刺激, その他のカードが非裁 決刺激であり, 各々 40 回呈示した. 3 刺激とも加算回 数は 20 回以上であった.

装置 事象関連電位と反応時間の測定には TEAC 製携 帯型多用途生体アンプ（Polymate AP1524）を用いた. 脳波は両耳架を基準部位として Fz, Cz, Pz から測定し た.

手続き 実験者は参加者に対し, シールドルーム内で 電極を装着した後, カードが入れてある 5 枚の封筒の 中から 1 つの封筒を選択させた. その後, 実験者は退 室し, 参加者は封筒からカードを取り出して記憶した. 記憶した後, 参加者はカードを封筒に戻し, 他の封筒 とは別の場所に置いて検查を受けた.

\section{結果及び考察}

Figure 1 は内向性群, Figure 2 は外向性群における 標的刺激, 裁決刺激, 非裁決刺激に対する総加算平均波 形 $(\mathrm{Pz})$ である. 内向性群, 外向性群ともに潜時 $400 \mathrm{~ms}$ 付 近に標的刺激に対する顕著な P 300 が認められる. 標的 刺激に対する波形は, 外向性より内向性群で N2b-P3a 差分が大きくなった. 裁決刺激と非裁決刺激の P300 は, 両群ともに潜時 $500 \mathrm{~ms}$ 以降で, 裁決刺激に対する P 300 の増大が見られる.

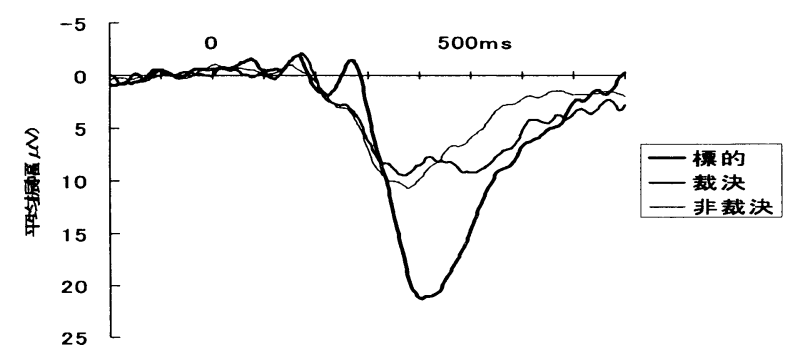

Figure 1. 内向性群の総加算平均波形( $\mathrm{Pz})$.

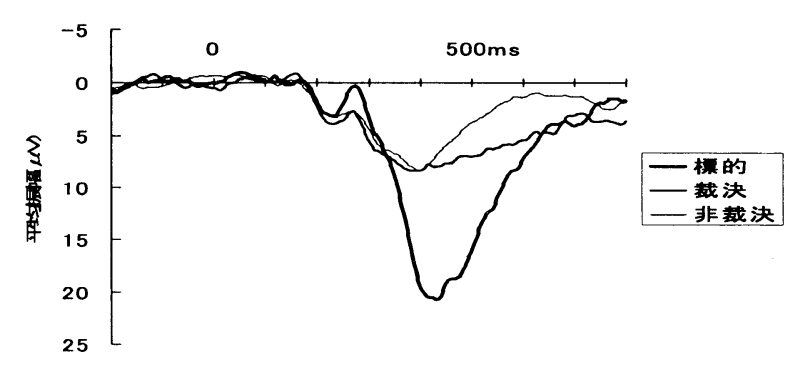

Figure 2. 外向性群の紛加算平均波形( $\mathrm{Pz}$ ).

両群における $100 \mathrm{~ms}$ 区間平均電位を $300 \mathrm{~ms}-600 \mathrm{~ms}$ の 間で 3 区間求め, 区間毎に向性次元（内向・外向） $\times$ 刺激（標的・裁決・非裁決）の反復測定のある 2 要因 分散分析を実施した. その結果，いずれの区間でも刺 激の主効果のみが認められ $(\not<.001)$, 向性次元の主効 果と交互作用は認められなかった. そして, 各刺激の 多重比較を Bonferroni 法で行った結果, 3 区間ともに 標的一裁決, 標的一非裁決の組み合わせで有意差が認

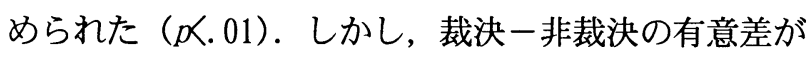
認められたのは $500 \mathrm{~ms}$ 区間平均電位のみであった. 本 実験では, 向性次元による差異は認められなかったが, 皮膚電気活動の同時計測など, 過去の研究との比較も 必要であろう.

【謝辞】本研究の実施にあたり，福山大学人間文化学 部心理学科下村康剛君, 西畑直哉君, 濱本有希さんの 協力を得た. 


\section{虚偽検出検查における認知処理に}

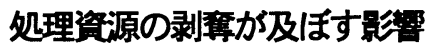

○久保賢太 (広島大学大学院 総合科学研究科) 宮谷 真人 (広島大学大学院 教育学研究科) 入戸野 宏 (広島大学大学院 総合科学研究科)

事象関連電位を利用した虚偽検出検査では, 1 種類の裁 決項目と 4-5 種類の非裁決項目を呈示し，それぞれに対 する P300 を測定することが多い。裁決項目に対する振 幅が非裁決項目に対する振幅よりも大きければ陽性とし て判定する。

P300 振幅を規定する要因として, 事象の主観的確率と 有意味性が知られている。しかし, 虚偽検出検査で得ら れる P300 振幅の差が, 裁決項目と非裁決項目の生起頻 度の違いによるものか, 項目間の有意味性の違いによる ものかは明らかでない。

本研究では, この点を検証するために, 単語を用いた 視覚 3 刺激オドボール課題を行った。低頻度で呈示され る単語に，模擬铅盗手続きによって有意味性を付与した 場合と付与しない場合における P300 振幅の差に注目し た。さらに, 虚偽検出検査から故意に注意をそらす心理 的カウンタメジャーが P300 振幅に与える影響を検討す るために, 主課題と並行して聴覚弁別課題を行わせ, 処 理資源を剥奪する二重課題条件を設定した。

\section{方法}

実験加者 大学生と大学院生 21 名(男性 10 名)。

課題 視覚 3 刺激オドボール課題では標的刺激(target, $p$ $=.17$ ), 非標的低頻度刺激(rare, $p=.17$ ), 非標的高頻度 刺激(frequent, $p=.66$ )の文字刺激に対して targetには 左ボタン押し，それ以外の刺激には右ボタン押しを求め た。刺激は文字・音声単語親密度が近い単語刺激(財布, 時計, 指輪, イヤリング, ネックレス, 通帳, ブローチ, カード, 宝石, ブレスレット)を使用し, そのうち 3 単語 をそれぞれの刺激に割り当てた。聴覚弁別課題では 1000 $\mathrm{Hz}$ と $850 \mathrm{~Hz}$ の 2 種類の音刺激をランダムに呈示し, 低 頻度 $(p=.40)$ で呈示される音の数を数えさせた。

手続き 参加者を, 統制群 $(n=11)$ と実験群 $(n=10)$ にラ ンダムに振り分けた。実験群は刺激に対する有意味性を 持たせるため, 事前に模擬的に物品を盗むことを教示さ れた。課題条件は視覚 3 刺激オドボール課題のみを課せ られる single 条件と, 同時に聴覚弁別課題を課せられる dual 条件を設けた。試行は 1 ブロック 144 試行行い， 3
ブロックを single 条件, 3 ブロックを dual 条件とし計 6 ブロック行った。

\section{ERP 測定}

国際 10-20 法による Fz，Cz，Pz，F3，F4，C3，C4, $\mathrm{P} 3, \mathrm{P} 4, \mathrm{O} 1, \mathrm{O} 2$ の 11 部位から両耳架を基準として脳 波を導出した。生体用アンプ（NEC-Sanei 製 6R12）に より帯域通過周波数 0.05-30 Hz で増幅し, デジタルレコ 一ダ (TEAC 社製 DR-M3 MK2) にサンプリング周波数 $500 \mathrm{~Hz}$ で記録した。垂直眼電図は，左眼窩上下縁部から 導出し, 脳波に影響するアーチファクトを除外した。電 極は銀塩化銀電極を用い，接触インピーダンスを $5 \mathrm{k} \Omega$ 以下とした。刺激呈示前 $200 \mathrm{~ms}$ から後 $900 \mathrm{~ms}$ までの $1100 \mathrm{~ms}$ 間を分析区間とし, 加算平均処理により ERP を算出した。

\section{結果と考察}

Figure 1 に Pz における dual 条件の群別総加算平均 $\mathrm{ERP}$ 波形を示した。処理資源の剥奪が P300 に及ぼす影 響を検討するため, P300 頂点振幅について群課題刺 激の分散分析を行った。その結果, 課題の主効果が見ら れた $(p<.05)$ 。また，群と刺激の交互作用が見られた $(p$ $<.05)$ 。多重比較を行ったところ, 実験群において rare が frequent よりも有意に高振幅だった $(p<.05)$ 。統制群 では rare と frequent の間に差は見られなかった。

これらのことから, P300を大きく生起させるのは刺激 の呈示頻度の違いに対する認知処理ではなく, 刺激の持 つ有意味性に対する認知処理が重要であることが示され た。有意味性の強い認知処理により反映された P 300 は, 処理資源の剥奪の影響を受けることなく頑健に生起する ことが明らかとなった。

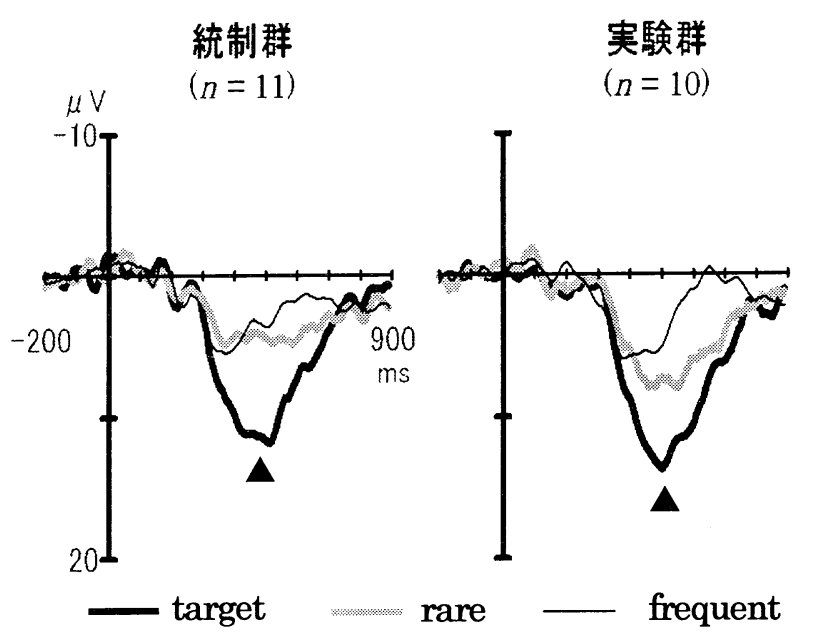

Figure 1. dual 条件における総加算平均 ERP. 


\section{NIRS-Imaging を用いた虚偽検出検查の検討 \\ ○細川 豊治 (関西学院大学大学院文学研究科) \\ 片寄 晴弘 (関西学院大学理工学部) \\ 八木 昭宏 (関西学院大学文学部)}

\section{【目的】}

虚偽検出検査では，犯罪事実に関する記憶の有無を 利用した GKT (Guil ty Knowledge Test) が利用されてい る。GKT により生起する生理反応は，中枢での認知情 報処理が重視されているため, 従来の末梢神経系指標 だけでなく中枢神経系の指標である事象関連電位 (ERP)や fMRI などを用いた虚偽検出研究がされている。 現在, 脳活動計測の新しい指標として利用されている NIRS (near-infrared spectroscopy)は，ERP を用いた 虚偽検出と比較して空間分解能が高く, 瞬目や体動に よるアーチファクトが少ないという利点がある。本研 究では，模擬窃盗課題後に虚偽検出検査を行い，NIRS による虚偽検出の有効性について検討した。

\section{【方法】}

被験者: 実験に同意した大学生 14 名 (男性 9 名, 女性 5 名)を被験者とした(平均年齢 21.6 歳)。

模擬窃盗課題: 無施錠の部屋に侵入し, テーブル上の 5 つの異なる物品 (ネックレス, カメラ, 電子辞書, 携帯, 香水)の中から 1 品窃取し, 隠し持ったまま元の部屋に 戻るという課題を被験者に課した。

測定装置:脳血流を測定に OMM-2000(島津製作所)を用 いた。測定部位は，国際 10-20 法の Fpz を基点として プローブを装着した(Figure 1.)

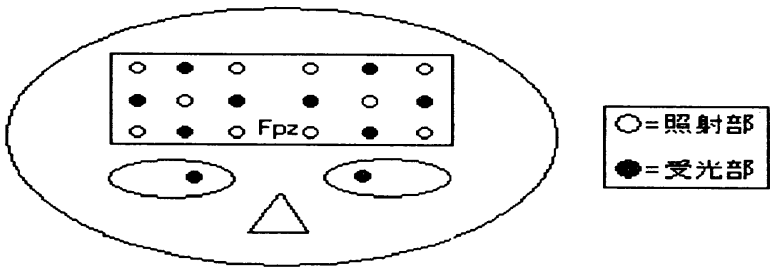

Figure 1. プローブの装着位置

刺激: 模擬窃盗課題時に使用した物品の写真と「盗ん だ物はこれですか」という質問文を同時にディスプレ イ上に呈示した。刺激呈示終了次後，できる限り早く 正確にボタン押しをさせた。呈示時間 8s-12s, 呈示間 隔 60 s とした。1 系列 5 問で裁決項目を $2 \sim 4$ 問のいず れかに呈示し，計 5 系列試行した。

分析:測定した $\mathrm{oxy}-\mathrm{Hb}$, deoxy-Hb 変化量のうち, oxy-Hb を虚偽検出の指標とした。1s ごとの平均反応量を算出 し，各系列内で標準化を行い，1s ごとの標準得点 (z-score) を算出した。刺激呈示前の 5s 区間でベース ライン処理を施した後, チャンネルごとにオフライン の加算平均を施した。また, 迷入光, プローブのずれ によるアーチファクトが観測された試行は除外した。

\section{【結果】}

被験者ごとに光路長が異なるため, 本研究では被験 者ごとに検出を行った。被験者全体の oxy-Hb 変動の傾 向として, 非裁決項目に比べ裁決項目において oxy-Hb 増加するという傾向が得られた。分析は，刺激呈示後 25 秒間の裁決·非裁決ごとの反応を $5 \mathrm{~s}$ ごとに平均を 出した。裁決·非裁決 (2) $\times$ 区間 (5) の分散分析後，裁 決·非裁決及び区間の主効果，交互作用が有意であり Tukey の HSD 検定により 3 区間以上、非裁決項目に比 べ裁決項目の方が oxy-Hb が有意 $(p<.05)$ であったチャ ンネルが 10 チャンネル以上であった際, 検出と定義し た。検出率は，14名中 10 名 (71\%)であった。

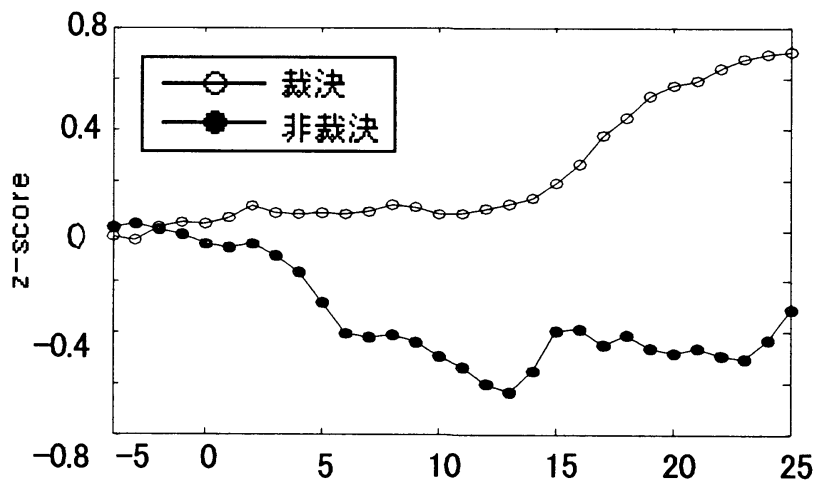

Figure 2. F4 付近の $\mathrm{oxy}-\mathrm{Hb}$ 濃度変化

\section{【考察】}

虚偽検出時において前頭前野領域のいくつかの部 分が局所的・選択的に反応するという fMRI を用いた先 行研究 (Spence et al, 2001) と同様に, 本研究におい ても前頭前野領域において非裁決項目時よりも裁決項 目時の方が oxy-Hb 濃度が高いという反応を示した。今 後の課題として, 検出定義を明確にしつつ, ERP, 脈波 や皮膚電気活動，呼吸との比較検討も行い検出精度を 高めていく必要性がある。

\section{【引用文献】}

Spence, S. A., T.F.Farrow , T.F.D. (2001). Behavioural and functional anatomical correlates of deception in humans. Neuroreport 12(13): 2849-53. 
虚偽検出に関する基礎的研究 : 音声指標による検討

○鈴木 将史 (駒澤大学大学院人文科学研究科)

種田桂介（日本電算企画株式会社）

軽部 幸浩 (駒澤大学文学部)

谷口 泰富 (駒澤大学文学部)

【目的】鈴木ら（1976）以後, 虚偽検出場面における 返答音声を検出指標として採用することの基礎的研究 が行われてきたが，一貫した方向性は見出されていな い。種田ら（2005）は，虚偽検出場面における指標の 変動の方向性の差異がカウンター・メジャーを背景に している可能性に言及している。そのため, 音声分析 に際しては, 返答毎のピッチや音圧の変動を調べる方 法が有効であり，そしてこの変動を調べるためには， サンプリング時間を考慮した研究が必要であることを 指摘している。本研究では, 被検査者の返答に冗長度 をもたせ，この変動性に注目した研究を行った。

【方法】実験参加者: 大学生 (男性9名, 女性 9名)。 使用機材：KAY 社 CSL4400, ヘッドセットマイク (COUNTRYMAN HEADSET), 紙箱, 木箱ほか

実験条件 : カード・テスト（トランプ・の 2,3,4,5,7）

手続き : 実験参加者に 5 つの紙箱のうち 1 つを選ばせ 別室で中身を確認するように指示した。紙箱の中には, 教示書と木箱のダイヤル錠の開錠番号を記した紙を入 れておいた。教示書では「このカードをよく憶えてお くこと」,「木箱に入っているカードを身に付けて隠す こと」,「隠したカードがばれないようにすること」な どが指示されていた。模擬窃盗課題を終えた実験参加 者に測定器具を装着し, 全ての手続きを確認させるた めの練習の後, カード・テストを実施した。実験での 質問は, CRT モニター上にカードの画像を 4 秒間呈示 した。実験参加者には, どの質問に対しても「いいえ, そうではありません」と，返答するように教示した。 実験での質問は 5 質問を 1 系列とし, それを 3 回繰り 返し呈示した。なお，質問の系列内順序は固定した。

【結果及び考察】すでに安木ら（2001）は, 虚偽検出 場面の音声分析から，基本周波数が指標となる可能性 を示唆しながらも, 変動方向は必ずしも同一でないこ とを報告している。本研究の結果は, 先の種田ら (2005) と同様であり, 音圧とピッチを, それぞれ単独の側面 から分析した場合には, 特異な傾向は認められなかっ た。そこで，裁決質問及び非裁決質問に対する返答音 圧及びピッチを，個人の平均値を基準にして分けると
Table 1 のような群構成となった。すなわち, 裁決質問 に対する返答の音圧が強くなる群 $(\mathrm{E}-\mathrm{H})$, 弱くなる群 (E-L), 同様にピッチが高くなる群 $(\mathrm{P}-\mathrm{H})$, 低くなる 群（P-L）の 4 群である。

Table 1 音圧・ピッチの違いによる群構成

\begin{tabular}{|c|c|c|c|}
\cline { 3 - 4 } \multicolumn{2}{c|}{} & \multicolumn{2}{|c|}{ 音 圧 } \\
\cline { 2 - 4 } \multicolumn{2}{c|}{} & E-H & E-L \\
\hline \multirow{2}{*}{ ピッチ } & P-H & 5 人 & 5 人 \\
\cline { 2 - 4 } & P-L & 3 人 & 3 \\
\hline
\end{tabular}

小林（2005）は，裁決質問に対する返答音声のピッ チが下がり, 音圧が弱くなることを報告している。そ こで, 本研究では, 予備的研究として, 小林の指摘に 類似する群（P-L・E-L）とその対極にある群（P-H・ $\mathrm{E}-\mathrm{H}$ ）の音声の特徵（音圧およびピッチのばらつき） を分析した。Fig.1 は, この両群のピッチの $S D$ につい て示したものである。

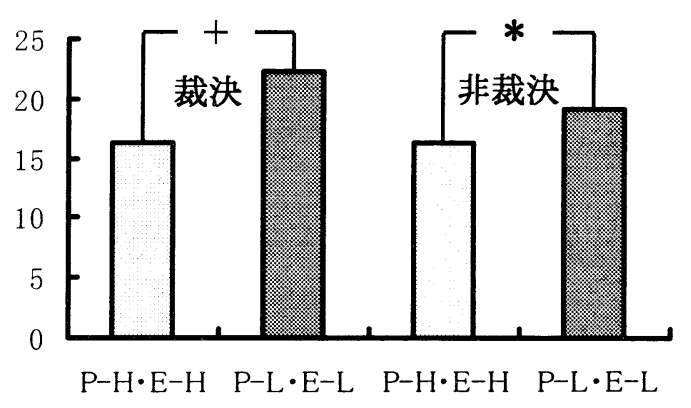

Fig.1 各群におけるピッチの $S D$

分析の結果, 音圧の $\boldsymbol{S D}$ に関する特別な傾向は認め られなかったものの，裁決質問に対する $(\mathrm{P}-\mathrm{H} \cdot \mathrm{E}-\mathrm{H})$ 群のピッチの $\boldsymbol{S D}$ は，(P-L・E-L）群のそれより小さく なる傾向が認められた $(p=0.1)$ 。また非裁決質問の場 合は, (P-H・E-H) 群の $\boldsymbol{S D}$ が明らかに小さくなって いた $(\boldsymbol{p}=0.05)$ 。結果的には, 両群共, 裁決質問と非裁 決質問の違いを反映したような音圧・ピッチの特徵的 な変動は認められなかった。しかし，裁決質問に対す る返答音声のピッチ及び音圧が高くなる場合 (群) は, 非裁決質問に対する返答音声のピッチ及び音圧が高く なる場合（群）に比へ，裁決質問のみならず非裁決質 問に対する返答音声のピッチ幅が小さくなる傾向が認 められた。すなわち, 音声指標の採用にはさらなる検 討が必要であるが, 音圧やピッチの変動方向が異なる 場合でも, 裁決質問と非裁決質問の両質問に対し, 明 らかに異なる返答や，ばらばらの返答が繰返されてい るわけではなく，両質問に対する発声上の差異を極力 小さくするような方略がカウンター・メジャーとして 採用されている可能性にも注目すべきであろう。 


\section{活動の規則性と朝型-夜型度との関連}

○浅岡 章一 (早稲田大学スポーツ科学学術院)

福田一彦（福島大学共生システム理工学類）

山崎 勝男 (早稲田大学スポーツ科学学術院)

\section{1. 目的}

先行研究は, 夜型の人の睡眠-覚醒パターンが朝型の 人と比較して不規則であることを明らかにしている (e.g., Giannotti et al., 2002). 本研究では朝型-夜型傾向が 腕時計型活動量計測装置によって測定された活動量の 規則性とも関連するかどうかを検討した。

\section{2. 方法}

2 月に 4 名, $4 \cdot 5$ 月に 4 名, 12 月に 11 名, 計 19 名 (男 9 名, 女 10 名) の大学生を対象とした. 被験者に は腕時計型の活動量記録装置 (Actiwatch-L®) を平日 の 4 日間装着させ, 通常生活における 30 秒毎の活動量 を測定した。 また，実験期間中，睡眠表をつけさせ， M-E scale (朝型 - 夜型尺度) 一の回答も求めた。

睡眠表の記録をもとに入眠時刻，起床時刻，総睡眠 時間を算出した. 活動量のデータについては，30 分ご とに平均した後, 被験者ごとに自己相関関数を算出し, $\mathrm{lag}=24 \pm 4$ 時間の間にある自己相関の最大值と最小値 の差を活動の規則性の指標として採用した．また自己 相関関数により算出された周期と 24 時間との乘離を, 活動周期の乱れの指標とした (Figure 1). 以上の変数と, $\mathrm{M}-\mathrm{E}$ 得点との間の相関をもとめた。

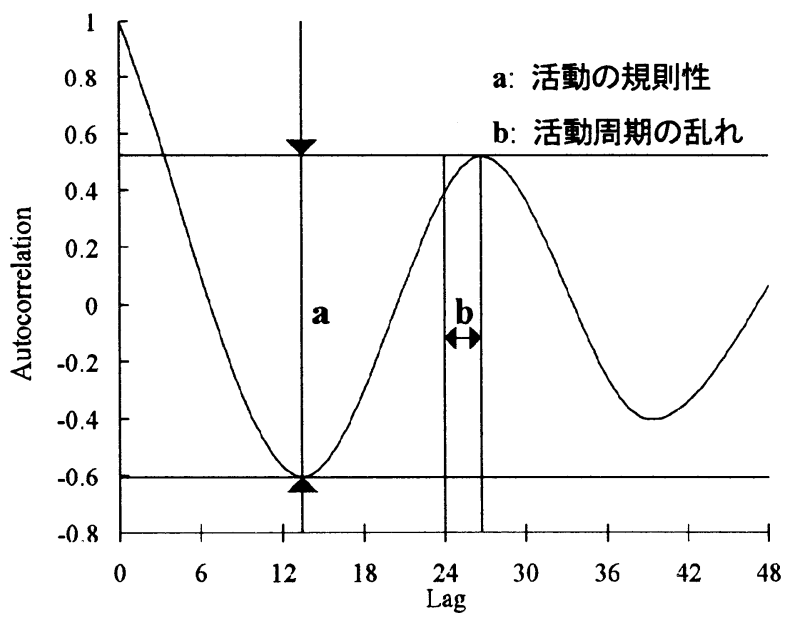

Figure 1 自己相関関数を用いた活動の規則性の指標

\section{3. 結果}

入眠時刻の平均は 01:39 $\pm 1: 16$, 起床時刻は $8: 25 \pm$ 0:50，総睡眠時間は 7:07 0:49であった。また，M-E 得点の平均は $45.84 \pm 9.23$ であった。

M-E 得点は, 入眠時刻 $(r=-.496, p<0.05)$ と起床時 刻 $(\mathrm{r}=-.583, p<0.01)$ との間に有意な負の相関を示し, 朝型傾向の学生は，早寝早起きであることが確認され た.

活動周期の乱れは，M-E 得点との間に有意な負の相 関を示し, 夜型傾向の人ほど, 活動量の周期が 24 時間 から乘離している傾向が認められた $(\mathrm{r}=-.499, p<$ 0.05). しかし，活動の規則性は，M-E 得点との間に有 意な相関を示さなかった $(r=.204$, n.s. $)$.

\section{Table 1 M-E 得点と睡眠·活動変数との相関係数}

\begin{tabular}{ccr}
\hline & \multicolumn{1}{c}{ 相関係数 } \\
\cline { 1 - 1 } 活動の規則性 & .204 & \\
活動周期の乱れ & $-.499^{*}$ & \\
入眠時刻 & $-.496^{*}$ & $* p<0.05$ \\
起床時刻 & $-.583^{* *}$ & $* * p<0.01$ \\
総睡眠時間 & .285 &
\end{tabular}

\section{4. 考察}

朝型傾向を示す人ほど，睡眠相が前進していること が確認された．腕時計型活動量記録装置によって測定 された活動の規則性は, 朝型-夜型傾向との間に有意な 関連を示さなかった。この理由として，大学生では日 中の活動量を規定する社会的要因（講義のスケジュー ルなど）に個人差の大きいことが考えられた.しかし， 夜型傾向の人ほど活動量の周期が 24 時間から乘離し ている傾向が認められたことや，本研究では被験者が 大学生だけであったことを考えると，活動量のパター ンと朝型-夜型傾向との関連については, 大学生以外の 被験者も対象として，更なる研究が必要であると考え られた。 
Post-lunch dip 時の短時間仮眠が気分及び主観的運動 強度に及ぼす影響

○山本哲朗 (広島大学生物圈科学研究科)

\#山崎昌廣 (広島大学総合科学部)

林 光緒 (広島大学総合科学部)

昼食後の時間帯に眠気やパフォーマンスや気分の低 下が起こる。この現象はPost-lunch dip とよばれてい る。Post-lunch dip は，運動パフォーマンスにも影響 を及ぼすと考えられる。また，Post-lunch dipの対処 法として，短時間仮眠が有効であることが報告されて いる。そこで、本研究では、Post-lunch dip の時間帯 にとる短時間仮眠が、その後の運動パフォーマンスに 及ぼす影響を検討した。

\section{【方法】}

実験参加者は、睡眠習慣に乱れがなく、仮眠の習慣 を持たない、運動部に所属している大学生 10 名（20.3 歳士1.2）であった。実験 1 週間前から睡眠日誌とアク チウォッチを用いて、睡眠習慣に乱れがないことを確 認した。

参加者は 12:30 から昼食をとり、脳波 (C3, C4, 01, 02)， 眼球運動，筋電位測定用の電極を装着した後， $14: 00$ から仮眠（仮眠条件）または休憩（休敀条件）をとっ た。仮眠は，初発の紡錘波もしくは K 複合波の出現か ら 3 分間とした。その後 15:00 から運動セッションを 行った。運動セッションは、自転車エルゴメータを用 いた。課題は漸増的に負荷が上がっていくもので，運 動終了までの時間を測定した。また運動中の生理指標 として心拍数を測定した。主観的指標として, 運動中 は 1 分毎に主観的運動強度を測定した。仮眠/休憩の前 後と運動直前にVisual analog scale (VAS) を用いて, 眠気と疲労を測定した。また運動の直前直後の気分に は短縮版 POMS を用いた。各条件の実施には 2 日間の間 隔をあけ、条件間の順序は参加者間で相殺した。

【結果と考察】

1. 前夜の睡眠と仮眠内容 実験前夜の睡眠時間は仮眠 条件で $5: 47$, 休䄭条件で $6: 00$ であり, 両条件に差 は認められなかった。仮眠の睡眠変数は，総睡眠時間 が 10.5 分, 段階W が 3.9 分, 段階 1 が, 7.0 分, 段階 2 が，3.4 分であった。また参加者全員において段階 2 が 3 分以上含まれていることが確認された。
2. 運動継続時間 運動継続時間は，仮眠条件で 16 分 52 秒，休憩条件で 16 分 35 秒であり，仮眠後の方が有 意に運動継続時間が長かった（ $t(9)=2.36, p=.04)$ 。 3. 心拍数 運動中の心拍数に差は認められなかった。 4. 主観的運動強度 (Figure 1) 条件の主効果が認め られ，仮眠条件の方が有意に主観的運動強度が低かっ た $(F(1,9)=8.35, p=.018, \varepsilon=1.00)$ 。したがって, 仮眠後の方が，同じ運動強度であっても「楽」であると 感じていることが示された。

5. VAS (Figure 2)および POMS VAS の眠気で条件 $\times$ 時 間の交互作用が認められた $(F(2,18)=8.96, p=.002$, $\varepsilon=.99)$ 。下位検定の結果, 起床直後および, 運動直前 で仮眠条件の方が眠気が有意に低いことが認められた （p.05）。また POMS の活気因子において条件の主効果 が認められ $(F(1,9)=10.19, p=.011, \varepsilon=1.00)$, 仮眠 条件のほうが活気が高いことが示された。

6. まとめ Post-lunch dip 時に短時間仮眠をとると， その後の眠気や活気, 運動パフォーマンスが改善する ことが示唆された。

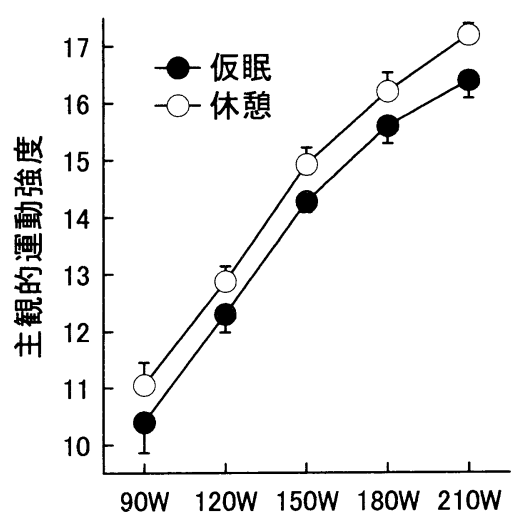

Figure 1 運動中の主観的運動強度

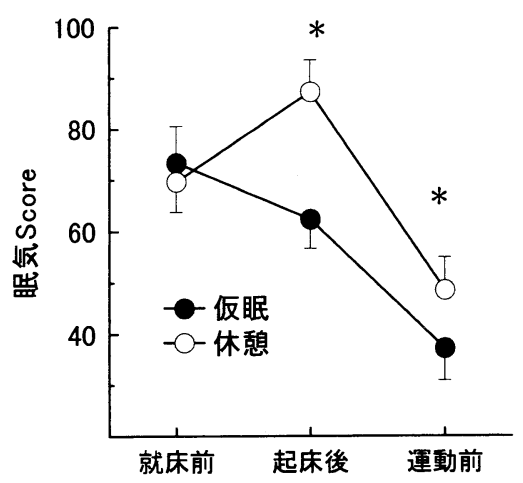

Figure 2 主観的眠気 


\section{座位姿勢における午後の短時間仮眠効果}

\section{一シート角度の違いによる仮眠効果一}

○阿部晃子（広島大学大学院生物圈科学研究科）

林 光緒 (広島大学大学院総合科学研究科)

堀忠雄 (広島大学大学院総合科学研究科)

【目的】

居眠り運転事故の発生時間帯は, 1 日に 2 回ピーク があり, 深夜から朝方 $(0: 00 \sim 06: 00)$ と昼下がり $(14: 00$ 〜16:00) である (西田，1999)。昼下がりの眠気は，前 夜に十分な睡眠をとっていても生じ，14:00 に最大と なる。昼下がりの居眠り運転事故を防止するには，こ の眠気を抑えることが必要である。これまで日中の眠 気の対処法として, 短時間仮眠法の有効性が明らかに されてきた。しかし，これらの効果はベッドで確認さ れたものであり，車両シートを用いた仮眠の効果は検 討されていない。居眠り運転事故の防止には，実際の 車両シートを用いて検討する必要がある。本研究の目 的は, シート角度の違いによる午後の短時間仮眠効果 を調べることであった。

\section{【方法】}

予備調査（n=20）の結果, 運転時のシート角度は $104.8 \pm 4.1$ 度, 20 分間仮眠想定時は $128.7 \pm 8.8$ 度, 60 分間仮眠想定時は $153.3 \pm 8.2$ 度であった。そこで, 実験参加者である若年成人 11 名 (女性 7 名, 男性 4 名, 平均 $21.6 \pm 1.3$ 歳)に対して, 105 度 [垂直の中心線 (90 度)から 15 度傾けた状態]で仮眠をとらない仮眠なし 条件, シート角度 130 度, または 150 度で 15 分間の仮 眠をとる仮眠条件の 3 条件を設定した。

参加者は 13:00 に脳波 (C3，C4，01，02), 眼球運動, 筋電位測定用の電極を装着し， 13:35 から VASによる 眠気の主観的評価 1 分, 安静時脳波測定 1 分, 四肢選 択課題 8 分, 視覚ヴィジランス課題 10 分からなる計 20 分間を 1 セッションとする作業を行った。14:00 か ら仮眠条件では仮眠を開始し, 睡眠段階 1 以上の睡眠 が 15 分経過した時点で起床させた。一方, 仮眠なし条 件では, 座位姿勢における入眠潜時平均 3 分 (阿部ら, 2005）と仮眠の 15 分を合わせた 18 分間新聞を読んだ。 その後, 再び 3 セッション(60 分間)の作業を行った。

【結果と考察】

\section{1. 主観指標}

仮眠前セッションをベースラインとして，仮眠後セ ッションの差分值を求めた。両仮眠条件は, 仮眠なし
条件よりも眠気が抑えられ，シートを用いた仮眠でも 短時間仮眠効果が認められた (ps<.05)。

2. 行動指標

(1)四肢選択課題（平均反応時間下位 10\%）（Figure 1）

全反応時間のうち遅かった $10 \%$ 平均反応時間は, 仮眠なし条件の方が 150 度仮眠条件よりも $200 \mathrm{~ms}$ 以上 有意に遅かった（p<.01）。

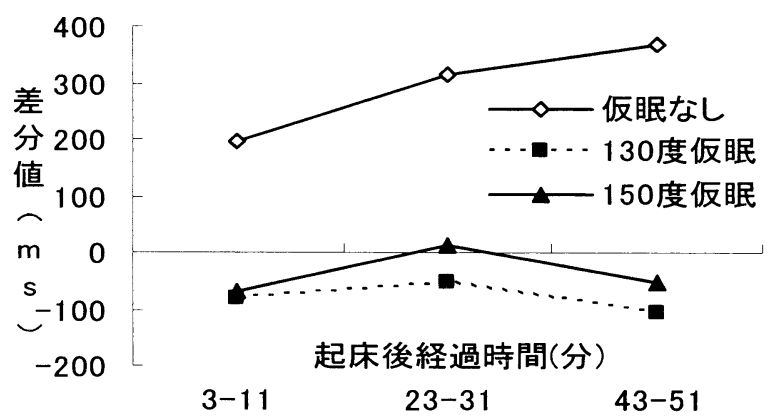

Figure 1 四肢選択課題(平均反応時間下位 10\%) (2)視覚ヴィジランス課題（正答数）

両仮眠条件ともに，仮眠なし条件よりも正答数が有 意に多く (psく.05)，短時間仮眠効果が認められた。

3. 仮眠内容（Table1）

水平に近い 150 度条件は，130 度条件よりも入眠潜 時が 3.1 分 (p<.05), 覚醒が 3.2 分 ( $p<.05)$, 段階 1 が 3.6 分短く $(\mathrm{p}<.01)$ ，段階 2 は 3.6 分長かった $(\mathrm{p}<.01)$ 。 Takahashi（2000)や Hayashi（2005)は，短時間仮眠の 回復効果の要因として, 段階 2 の出現を指摘している。 150 度条件は, 130 度条件よりも寝つきやすく, より回 復効果が高い眠りであったと考えられる。

\begin{tabular}{lrrrr}
\multicolumn{1}{c}{ Table1 } & 仮眠中の睡眠変数 & \multicolumn{3}{c}{$（ ）$ 内は SD } \\
\hline 睡眠変数 & \multicolumn{1}{c}{130 度 } & \multicolumn{1}{c}{150 度 } & \multicolumn{1}{c}{$\mathrm{t}(\mathrm{df}=10)$} & $\mathrm{p}$ \\
\hline 総就床時間 & $21.3(4.00)$ & $18.1(1.60)$ & 2.71 & .02 \\
入眠潜時 & $6.6(4.70)$ & $3.5(1.10)$ & 2.32 & .04 \\
総睡眠時間 & $14.9(.75)$ & $14.9(.27)$ & .11 & n.s. \\
覚醒 & $6.4(4.10)$ & $3.2(1.40)$ & 2.64 & .03 \\
段階1 & $10.2(3.90)$ & $6.6(2.20)$ & 3.30 & .01 \\
段階2 & $4.7(3.60)$ & $8.3(2.20)$ & -3.71 & .00 \\
段階3 & - & - & & \\
段階4 & - & - & & \\
段階REM & - & - & & \\
\hline \multicolumn{5}{c}{ 【まとめ】 }
\end{tabular}

車両シートにおいても短時間仮眠の効果が確認さ れたが，主観指標や行動指標にはシート角度による違 いは認められなかった。しかし，150 度条件は 130 度 条件よりも，寝つきやすく段階 2 が多く出現したこと から，水平に近いシート角度で仮眠をとった方が，よ り効率的な仮眠内容を得ることができると考えられる。 


\section{レム睡眠期の後期陽性成分に及ぼす刺激間隔の効果}

○高原 円 (広島大学大学院 総合科学研究科)

(日本学術振興会 特別研究員 PD)

入戸野 宏 (広島大学大学院 総合科学研究科)

堀 忠雄 (広島大学大学院 総合科学研究科)

\section{1. 背景}

近年，睡眠研究における脳波はその役割を見直され てきており，レム睡眠期の脳活動は夢, 学習・記憶, 行動障害などの研究において重要視されている。事象 関連電位 (event-related potential, ERP)は, 特定の 事象に関連する脳波の一過性の電位変動を示し，目に 見える行動反応が必ずしも得られない睡眠中の脳活動 を調べることに適している。レム睡眠期に音刺激に対 して出現する ERP として，P200，N300，P400 などが確 認されている。Takahara et al. (2004)では，30秒以 上刺激間隔をあけることによって，刺激感覚闇值の低 いと言われているレム phasic 期 (急速眼球運動頻発 期) に後期陽性成分 (P400)をようやく確認することが できた。このことから，P400 が刺激間隔が長いほど振 幅が大きくなるという性質を持つ可能性が考えられた。

本研究では，レム睡眠期にみられる事象関連電位の 成分である P200，N300，P400 振幅それぞれについて， 刺激間隔を段階的に長くしていったときの振幅に及ぼ される効果を比較検討することを目的とした。

\section{2. 方法}

\section{実験参加者}

大学生・大学院生 8 名 (21-26 歳, 平均 22.6) が実験 に参加した。

\section{刺激}

$2000 \mathrm{~Hz}$ 純音を用い, シングルトーンのオドボール 刺激とした。刺激強度は $60 \mathrm{~dB} / \mathrm{SPL}$ ，持続時間は $50 \mathrm{~ms}$ で，刺激の立ち上がり・立ち下がりにそれぞれ $10 \mathrm{~ms}$ 設けた。刺激のオンセット間間隔（SOA）を，1.5，3， 6, 12, 24, 48 秒とした。SOA の順序はランダムとした。

\section{手続き}

順応夜の後, 実験参加者の通常就床・起床時刻に合 わせ終夜睡眠ポリグラフ記録を行った。

インサート式のイヤホンを両耳に固定してベッドに 横にさせ，朝，予定の時刻に実験者が起こすまで，聞 こえてくる音刺激を聞き流しながら眠るように教示し た。
記録

脳波を頭皮上 28 部位 (Fp1，Fp2，Fpz，F9，F10，F7， F8, Fz, F3, F4, T3, T4, Cz, C3, C4, P9, P10, T5, T6, Pz，P3，P4，01，02，0z，M1，M2，Iz)から記録した。 眼電図, 頣筋電図も同時に記録した。

脳波はサンプリング周波数 $500 \mathrm{~Hz}$ で記録し，両耳氺 基準に再基準化し，時定数を 5 秒として分析を行った。 高域遮断フィルタ $60 \mathrm{~Hz}$ であった。

分析

Rechtshaffen \& Kales（1968）の国際判定基淮 に準拠し，30 秒判定でREM 睡眠と判定された区間を分 析対象とした。刺激呈示前 $100 \mathrm{~ms}$ から 1 秒区間を加算 平均した。分析区間内に脳波振幅が $\pm 80 \mu \mathrm{V}$ を超えた 場合や急速眼球運動が見られた場合は分析から 除外した。各 $\mathrm{ERP}$ 成分の頂点振幅について，繰り返し のある分散分析を行った。

\section{3. 結果と考察}

P400 振幅において, 刺激間隔の主効果が認められた （図 1)。レム睡眠期の後期陽性成分 P400 については, 刺激間隔が長いほど振幅が増大するという特徵が示唆 されたことから，P400 は刺激の顕著性を反映する外因 性の性質も示すことが明らかになった。

P200 や N300 振幅には，刺激間隔に伴うリニアな変 化は見られず，また異なる機能を反映する可能性が示 唆された。

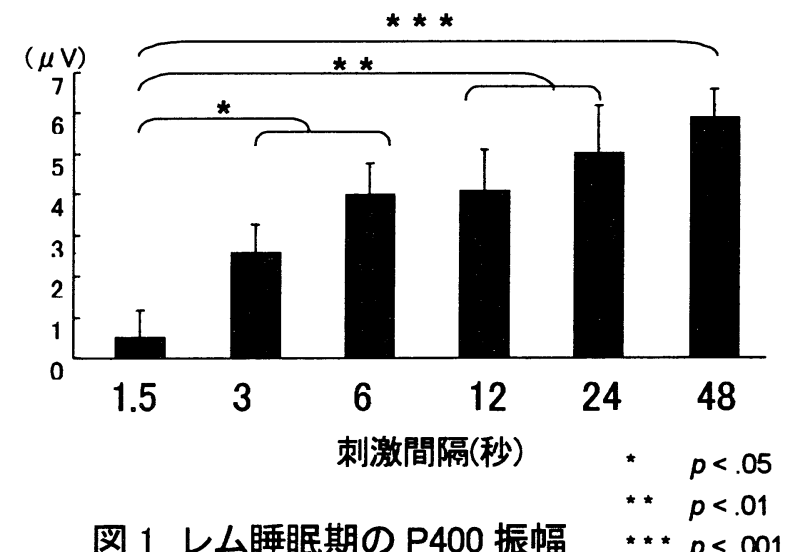

引用文献

Takahara M, Miyamoto 0, Nittono H \& Hori T. 2004 Auditory event-related potentials from a single-stimulus paradigm during rapid eye movement sleep. Sleep and Biological Rhythms, 2: 150-152. 


\section{覚醒一睡眠移行期における}

\section{覚醒水準の減衰過程に関する検討}

○平野晋吾 (北海道大学大学院教育学研究科)

広重佳治（鳥取大学地域学部）

室橋春光 (北海道大学大学院教育学研究科)

覚醒から睡眠段階 1 への移行は，主に区画時間に対 する脳波 $\alpha$ 波の出現時間率（\%time $\alpha$ ）が 50\%未満に 減衰するか否かという 2 件法に基づいて判定される。 しかし, 同じ段階内においても\%time $\alpha$ は常に変動し ている。これまでに, 覚醒一睡眠移行期における\%time $\alpha$ の時間変動は単調な减少過程ではなく, 約 70 秒周期 の増減変動を伴うなど, 一定のパタンを有することを 示した。本研究では, \%time $\alpha$ に加えて, 脳波 $\alpha$ パワ および $\theta$ パワの関係及び $\alpha$ パワの前頭/後頭比の時間 変動を指標とし, 覚醒-睡眠移行期における行動維持の 失敗を手がかりに，覚醒水準の減衰過程について検討 する。加えて入眠判定の客観的指標についても検討す る。

$$
\text { 万法 }
$$

【実験参加者】睡眠障害のない健康な大学生計 10 名

(男 5 名, 女 5名, 22 28 歳)【記 録】睡眠ポリグラ フ(PSG)は, 脳波 $(\mathrm{C} 3, \mathrm{C} 4, \mathrm{Fz}, \mathrm{Cz}, \mathrm{Pz}, \mathrm{Oz} ; \mathrm{TC}=.3 \mathrm{~s})$, 水平 眼球運動 $(\mathrm{E} 1-\mathrm{A} 2, \mathrm{E} 2-\mathrm{A} 2 ; \mathrm{TC}=6.0 \mathrm{~s})$, オトガイ筋筋電図 $(\mathrm{TC}=.01 \mathrm{~s})$ を標本化周波数 $128 \mathrm{~Hz}$ で $\mathrm{AD}$ 変換し磁気記 録した。【手続き】《交代式 $\operatorname{tap}$ 運動課題》人差し指に テーピングで固定した小型ロードセルを親指で繰り返 し押す課題であり，参加者は閉眼仰臥位で，左手 10 回一右手 10 回の tap 運動を交互に出来るだけ長く継続 することを求められた。tap 間間隔及び, 左右手の切り 替え間隔は “1 秒間”とし，事前にタイミングを練習 した。また， tap 圧は，「できるだけ同じ強さで押すよ うに」教示した。練習試行終了後, 14:30 り本試行を開始し，40 分間 PSG と同時記録した。【デ 一夕整理】《分析対象》アーチファクトの混入のない記 録（男 4 名，女 4 名)。《脳波活動( $\mathrm{Fz}, \mathrm{Cz}, \mathrm{Pz}, \mathrm{Oz})\rangle 5$ 秒区画毎に定量化。《\%time $\alpha\rangle$ 帯域通過 FIR フィル 夕 $(8,13 \mathrm{~Hz} ;-6 \mathrm{~dB})$ の濾過波形より 5 秒区画時間に対 する $\alpha$ 波出現時間の割合として算出した。その後，移 動平均法により平滑処理 $(m=6)$ することにより周期 性変動を抽出し，\%time alpha $の$ 减衰期及び回復期を視 察により判定した。《脳波パワスペクトル》FFT 法によ
り $\alpha(8 \mathrm{~Hz} \sim 13 \mathrm{~Hz}), \quad \theta(5 \mathrm{~Hz} \sim 7 \mathrm{~Hz})$ の各帯域毎に算出した 後 $\log$ 変換し, 次式により $\alpha / \theta$ 比を部位毎に算出した。 式: $\operatorname{power}(\alpha) /(\operatorname{power}(\alpha)+\operatorname{power}(\theta))$ また，同じく $\alpha$ パワ值の前頭/後頭比を算出した。

\section{結 果. 考 察}

\%time $\alpha$ は, tap 維持失敗の直前から周期性変動が明 瞭化し，その周期は約 70 秒（自己相関係数 $: r=.86$ )

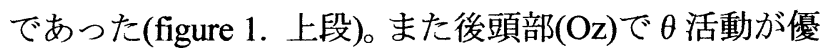
勢 (figure 1. 中段) になると, tap 維持の失敗が連続す

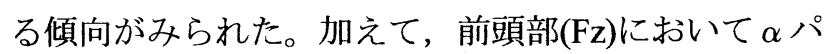
ワが優勢になると共に tap 維持に失敗し，優勢部位が 後頭部から前頭部へと漸進的に入替わる時期に tap 維 持の失敗が連続する傾向にあった（figure 1. 下段）。
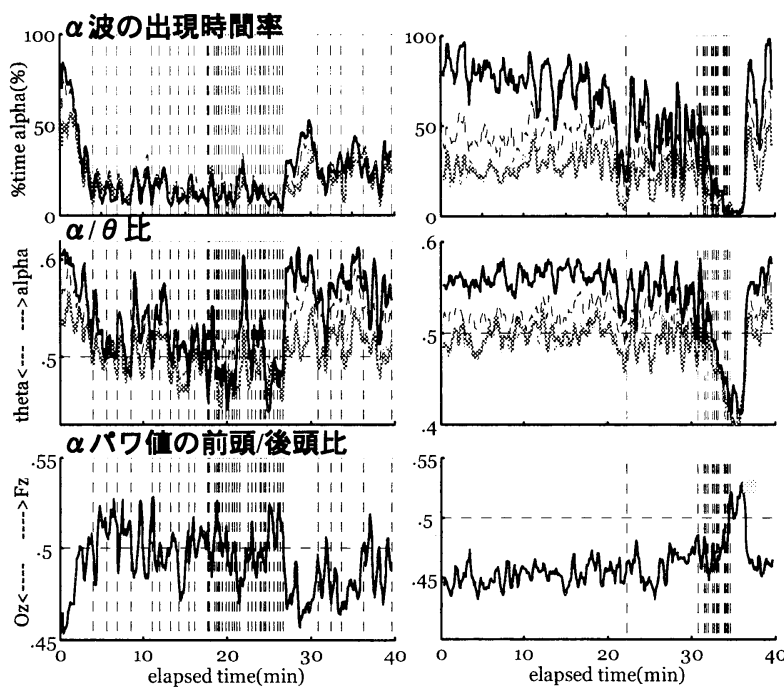

Figure 1. tap 維持の失敗時点 (破線)における

$\alpha$ 活動および $\alpha / \theta$ 比の振舞い(2事例)。

中段は $\alpha / \theta$ パワ比 : $[\operatorname{power}(\alpha) /(\operatorname{power}(\alpha)+\operatorname{power}(\theta))]$ 。 $\alpha / \theta<.5$ は， $\theta$ 帯域パワの優勢を示す。下段は $\alpha$ パワ值の $\mathrm{Fz} / \mathrm{Oz}$ 比 : $[\mathrm{Fz} /(\mathrm{Fz}+\mathrm{Oz})]$ 。 $\mathrm{Fz} / \mathrm{Oz}<.5$ は $\mathrm{Oz}$ 優位を示す。

本研究の結果から, (A) $\alpha$ パワ值が一時的に前頭優位 になり, 行動維持の失敗が起こるが，失敗に感度があ り, 直ちに覚醒反応が起こる時期，(B) $\alpha$ 活動の約 70 秒周期の増减変動が明瞭化し， $\alpha$ パワ值の優勢部位が 後頭から前頭優位に漸進的に移動するとともに，後頭 部で $\alpha<\theta$ となって, 行動維持が繰り返し失敗する時 期, (C)更に $\theta$ 波が連続するとともに行動が一時停止す る時期の順に覚醒水準が低下するが，それぞれの時期 の長さには個人差があることが示唆された。この結果 から，入眠潜時など判定のには，この個人差を考慮に 入れることが望ましいと思われるが，さらに詳細な分 析が必要である。 


\section{覚醒維持条件下における睡眠状態から覚醒状態への移 行過程 一 音刺激に対する行動反応, 脳波段栺からの 検討 -}

保野孝弘(川崎医療福祉大学医療福祉学部)

【はじめに】従来より, 入眠(sleep onset)を調べた研究は数 多いが, 睡眠からの覚醒(“出眠”)を検䛉た研究は極めて 少ない。Kleitman(1963)は, 睡眠から覚醒への移行過程は, 外的刺激によって覚醒させる場合を除けば, 入眠過程と逆の 過程をたどるとした。保野ら (2002，2003) は，睡既功覚醒し た(「目覚めた」)と気づいた時に, 押しボタンを4回押させる 方法(behaviorally signaled awakening; BSA)を用いて、睡勘 ら覚醒への移行過程における脳波像などの変化を検討した。 その結果、睡朋状態力ら緩徐に覚醒に至る場合と, 数秒で覚 醒に至る場合があることが示唆された。今回は, 音刺激に対 するボタン押反応を連続的に記録し，その消失と回復から 行動的覚醒を定義し, ボタン押し反応消失直後及び反応回 復直前の脳波段階の推移を検討した。また, 行動的覚醒直前 の $\alpha$ 波の有無と主観的意識体験との関係も検䛉た。睡蔇 ら覚醒一の移行例をより多く收集する目的加, 昼間を利用 し, 覚醒を維持寸る教示の下, 座位状態で記録した。

【方法】被験者は, 心身共に健康な大学生 18 名(男8 名;女 10 名;20〜28 歳)であった。記録指標は, 脳波(Fpz, Fz, Cz, $\mathrm{Pz}, \mathrm{Oz}$ ), 眼球運動(水平・垂直), オトガイ下筋笳電図などで あった。記録中, 音刺激がイヤフォンを通して被験者に提示 され、それが聞こえたら利き手に装着された押しボタンを1回 押すよう教示した。その反応は、記録紙上に記録された。被 験者は電極装着後, イヤフォンを装着し, 安楽椅子に座位姿 勢をとった。安静開眼·閉眼状態を各20秒記録した後, 120 分 の記録を行った。ポリグラフ記録は, 13 時〜 17 時の間で実施 した。記録中に, 少なくとも3回連続したボタン押し反态が認 められたら, 実験者はシールド室に入り, 主観的意識体験 (覚醒感, 睡眠深度など)を聴集した。その後, 同様の教示を 与え, 再度入眠を許可し,この手続きを記録終了まで繰り返し た。また, 120 分の記録後, 安静開眼・閉眼状態を各 20 秒記 録した。脳波段階は C3 部位を対象として, Hori et al.,(1994) の入眠期脳波段階判定基淮に基づき, 1 エポック 5 秒每に判 定した。判定区間は, 反応が消失した直前の音刺激から前 1 区間(0〜 5 秒前:S1), 反応が消失した区間に続〈2区間(0〜 5 秒後:SS1;5〜10 秒後:SS2)。再び反応が観察された区間の 前2区間（0〜5 秒前: W1;5〜10 秒前:W2)であった。音刺
激に対するボタン押反応が少なくとも3回連続して消失し， 再び反応が3回連続して認められた場合を分析の対象とし た。

【結果及び考察】ボタン押店消失直後(SS1) では段階 2 (21.7\%), 段階3 (39.1\%)の出現率が共に 4.3\%に低下， 段階6 (4.3\%)の出現率が, SS2 で 13.0\%に上昇した。一方， ボタン押し反応が回復した区間の 2 区間前(W2・W1)から, 段階1，2,3の出現率が高くなり, W2 での段階5の出現率 (52.1\%) は直前の1区間前(W1)で 17.3\%に低下した。 $\alpha$ 波 の伴亏全脳波段階(段階 1，2，3）の出現率を区間每に求め, その推移を検䛉た結果, ボタン押消失直後の区間(SS1・ SS2)では, その出現率(60.8\%)はそれぞれ 8.6\%と 13.0\%に 低下した。一方, ボタン押回復直前(W2・W1)では， $\alpha$ 波を 伴う脳波段階の出現率が, $43.4 \%$ 加 $56.5 \%$ ○徐々に高くな った。この場合, 音刺激によって, 覚醒反応 $(\alpha$ 波の出現な ぞ)がもたらされ，行動的覚醒に至った場合や， $\alpha$ 波が認め られる状態に音刺激が呈示されても, 反応が見られなかかた 場合が考えられる。後者は， $\alpha$ 波の出現之行動反応が一致し ない場合があることを示している(Campbell \& Webb, 1981; Anch et al., 1982; 保野他, 1991)。一方, 残る約40\%の脳波 段階では， $\alpha$ 波の出現は随伴していなかった。すなわち， 行動的覚醒の直前 0 ～10秒以内では脳波的睡眠状態にあり， 極めて短時間の中で $\alpha$ 波が随伴せず, 行動的覚醒に移行し たと考えられる。従って, 緩徐に状態が変化し行動的覚醒に 至る場合と, 瞬時に行動的覚醒に至る場合があることが示唆 される(保野他, 2003, 2004)。ボタン押反応回復直前の区 間で $\alpha$ 波が随伴していた場合 ( $\alpha$ 波出現群) と随伴していな い場合 $(\alpha$ 波非出現群)に分けて, 覚醒後の主観的意識体験 を比較した。 $\alpha$ 波出現群では,「眠っていない (16.7\%)が認 められたが， $\alpha$ 波非出現群では認められなかった。 $\alpha$ 波非 出現群では,「うとうとしていた」が 64.7\%と最も高く,「中程度 の眠りと評価た例が 17.7\%に見られた。れは， $\alpha$ 波の存 在とその時の主観的睡眠深度とが関連することを示している。 今後は,もしこのような2つの“出眠”経過が存在するならば, この違いをもたらしているものは何か, また, 主観的意識体 験にどのような違いがあるかを調べることが重要であろう。 
睡眠慣性が起床後 1 時間のスイッチコストに 及ほす影霓

○池田大樹

(広島大学生物圈科学研究科)

林 光緒

(広島大学総合科学部)

\section{【序 論 】}

睡眠から覚醒した後に生じる眠気の継続や作業パフ オーマンスの悪化といった現象は睡眠慣性と呼ばれる. 現代社会において，夜型化の進行に伴い睡眠時間が短 縮化し，その睡眠時間の不足から， 日常的に睡眠慣性 が生じていることが考えられる．本研究は，参加者の 平均的な睡眠時間眠った時の睡眠慣性を測定し，日常 的に睡眠慣性が出現しているかを検討した．睡眠慣性 を測定する指標として，本研究では前頭葉機能を反映 するスイッチコストの他, ヴィジランス, 主観的眠気, 疲労，気分，意欲を用いた。

\section{【方 法 】}

参加者 男性 3 名, 女性 6 名の大学生, 大学院生が実 験に参加した. 平均年齢は $21.8( \pm 0.5)$ 歳であった. 生理指標 脳波 (C3，C4，01，02)，水平眼球運動，筋 電図, 心電図, 呼吸活動を記録した.

課題 1 セッション(15 分)につき, スイッチコストを 測定するスイッチング課題 (7 分)，ヴィジランスを反映 する聴覚単純反応課題 (6 分), そしてVASによる眠気, 疲労, 気分, 意欲の測定 (1 分)を行った. 1 セッション の時間は 15 分であった.

手続き 実験 1 週間前から睡眠日誌の記録とアクチウ オッチの装着を参加者に要請し, 生活統制の確認を行 った. 就床時刻と起床時刻は, 各参加者の日常的な時 間に合わせた. 実験は 5 夜連続で行い, 1 夜目は順応夜, 2 夜目は強制覚醒夜， $3 ， 4 ， 5$ 夜目は自己覚醒夜で，今 回, 強制覚醒夜のデータを用いて検討した. 実験当日， 参加者は就床時刻の 45 分前に実験室に入室し, 課題を 1 セッション (15 分)行った後, 就床時刻に就寝した. 翌朝，参加者の日常的な起床時刻に，参加者を強制的 に起こした. その後, 4セッション(1時間)課題を行い, 実験を終了した。

分析 行動・主観指標については, 睡眠前と覚醒直後 との間で対応のある $\mathrm{t}$ 検定を行い，睡眠慣性の有無を 検討した。また，覚醒後セッションの得点を睡眠前と の差分值で算出し, 覚醒後セッションの変化を, 1 要因 の分散分析を行うことで, 睡眠慣性の変化を検討した.

\section{【結 果】}

生活統制に不備があった 1名を分析から除外した.

睡眠内容について, 総就床時間は 7 時間 22 分, 総睡眠 時間は， 7 時間 7 分，睡眠潜時は 96.5\%，睡眠潜時は 2.9 分となっており，睡眠は良好に保たれていた。

睡眠前と覚醒直後の変化について，スイッチコストに 有意差は認められなかった $(t=-0.974, d f=7, n s)$. ᄂ かし, 聴覚単純反応課題の反応時間は延長した $(t=-2.580$, $d f=7, p \times .05)$. また, 眠気が増加し $(t=-3.517, d f=7$, $p \nless .05)$, 気分 $(t=-2.606, d f=7, p \nless .05)$ と意欲 $(t=-3.133$, $d f=7, p \ltimes .05)$ は低下した. 覚醒後 4 セッションの変化に ついて，眠気にのみ時間の主効果が認められた。 下位検 定の結果, 覚醒後 0-15 分と 45-60 分の間に傾向差が認め られた ( $p$ ×.10). また, 行動指標について, 反応速度の上 位·下位 $20 \%$ に分け, 再分析を行った. その結果, 聴覚反 応課題の反応が早かった上位 $20 \%$ にのみ主効果が認めら れた $(F(3,21)=3.853 ， \not \subset .05)$. 下位検定の結果, 覚醒後 0-15 分と 45-60 分の間に傾向差が認められた $(\not \times .10)$.

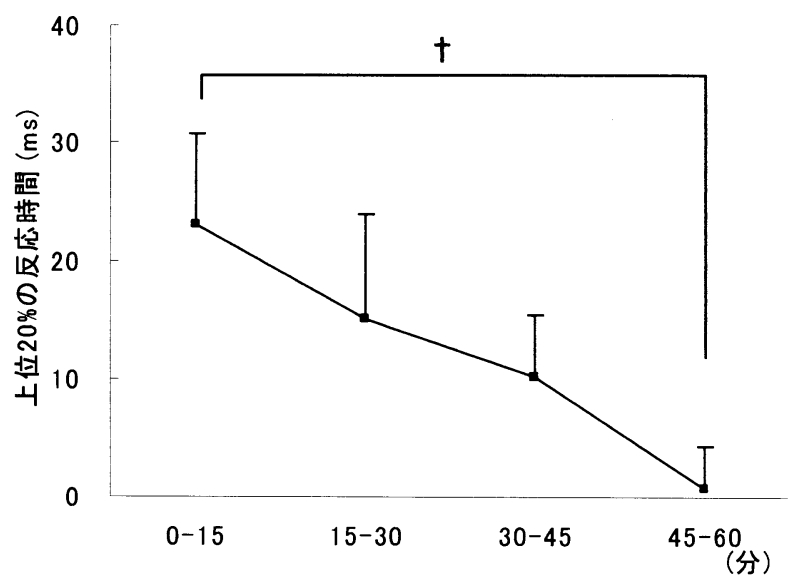

Figure1. 聴覚単純反応課題の覚醒後の反応時間の変化. †は $\mathrm{p}<.10$ を，誤差線は標準誤差を示す。

\section{【考察 】}

本研究の結果，前頭葉機能の低下は確認できなかった が，ヴィジランスの低下や眠気の悪化が認められた。こ れは，睡眠慣性が生じたことを示唆している．本実験に おいて, 参加者はおよそ 7 時間 30 分眠っており, 参加者 は日常的な睡眠時間眠ったといえる.このことは，日常 的に睡眠慣性が生じている可能性を示唆している.

今後, この睡眠慣性を低减するための方略, 例えば, 覚醒前から起床の準備が行われ，覚醒が快適になる自己 覚醒についての研究を行う必要性が示唆される. 
クルーズコントール使用が心拍活動に及ぼす効果

… 高速自動車道での長時間運転による検討 -...

畑山 俊輝 (八戸大学人間健康学部)

最近の自動車は単なる移動の道具の意味を超え, IT による先進技術にもとづく多様な機能が付加さ れた生活必需品へと変貌を遂げている。しかし，こ れらがドライバーの安全性や快適性をどの程度高 めているのかについては不明な点が多い。本研究で はクルーズコントール cc の運転負担への効果を高速自動車 道で害車を用いて心拍の他，右足の動作計測等の測 度により評価しようとした。 cc はドライバーから右 足によるアクセル調節を解放するので，運転を楽に するとされる。身体活動水準をそれにともなって低 减させることにより，心拍活動に低下がみられるか どうかを検討した。

\section{方 法}

参加者(自己観察者) : 被験者は発表者自身(H.T.)であ った。実験的走行時の満年齢 63 歳男性，運転歴は 37 年で，その間，事故歴はない。実験車：トヨタプ リウス S (型式 ZA-NHW11) 2001 年製のハイブリ ッド車で，排気量 $1500 \mathrm{CC}$ 自動変速機付の車両であ った。定速制御の範囲は約 $40 \mathrm{~km} / \mathrm{h}$ から約 $100 \mathrm{~km} / \mathrm{h}$ で, ccのスイッチ操作一回毎に記憶車速を約 1.5 $\mathrm{km} / \mathrm{h}$ 増減できる。実験的走行路：八戸自動車道と東 北自動車道とに設置されている福地 PA と鶴巣 PAの 約 $280 \mathrm{~km}$ の区間を使用した。この 2 つの自動車道 は地理的条件々交通量に違いがある。実験的走行期 間は 2005 年 5 月から同年 10 月までの間であった。 測定尺度 : 作業負担を cc がどの程度軽減するかを推 定するために，右足のアクセル操作がなくなった場 合の身体的な面での作業負担と，心理的な面での負 担とに分けて検討した。前者にはアクチウォッチと ポラー心拍計を, 後者には心的負担度を測定するた めのメンタルワークロード尺度(NASA-TLX)などを 用いた。

手続き：走行は八戸から仙台への上り方向と仙台か ら八戸への下り方向とで行った。これを cc 条件か通 常運転(nd)条件かで行うようにした。cc 条件では, 初期設定速度を $95 \mathrm{~km} / \mathrm{h}$ とした。通常運転条件でも できるだけ $95 \mathrm{~km} / \mathrm{h}$ で走行するようにした。なお， 八戸自動車道は最高速度が $80 \mathrm{~km} / \mathrm{h}$ に規制されてい るため，設定速度をそれに合わせるようにした。
結果と考察

八戸一仙台間で 5 回の実験的走行のうち 2 往復分 の資料を用いた。この 5 回の走行の平均所要時間は 173.6 分( $(\mathrm{sd}=1.3)$ であった。

1 ）右足の動作量：走行の前半と後半に分けて Kruskal-Wallis の順位による分散分析を行った。 Aug 7 の「仙台 $\rightarrow$ 八戸 (cc なし)」, Aug10の「仙台 $\rightarrow$ 八戸 (ccあり)」, Aug11の「八戸 $\rightarrow$ 仙台 (cc なし)」 を対象とした。前半および後半ともに, Aug7, Aug10, Aug11 の順に 3 つのサンプル間に有意差があり, cc なし条件では高い值を示した。また，cc なしの条件 であっても仙台 $\rightarrow$ 八の方が八戸 $\rightarrow$ 仙台より強度が 大であることも示唆された。これは両自動車道の交 通量の違いと関係した。また，同じ仙台 $\rightarrow$ 八戸゙も cc のある場合の動作強度はきわめて低かった。

2) NASA-TLX : 8 つの尺度の単純平均を求めた。結 果から，下り方向では， cc条件での運転であっても (Aug11) 作業負担得点はnd 条件 (ccなし)のそれを上 回っていた。これをみる限り, cc は運転負担を軽減 していなかった。しかし，交通量が低下した Aug22 では負担量も低下した。

3 ) 心拍 : NASA-TLX の結果にもとづき，描いた心拍 曲線が Figure 1 である。これにより，cc ありの下 り方向では心拍レベルが低下することが示唆された。

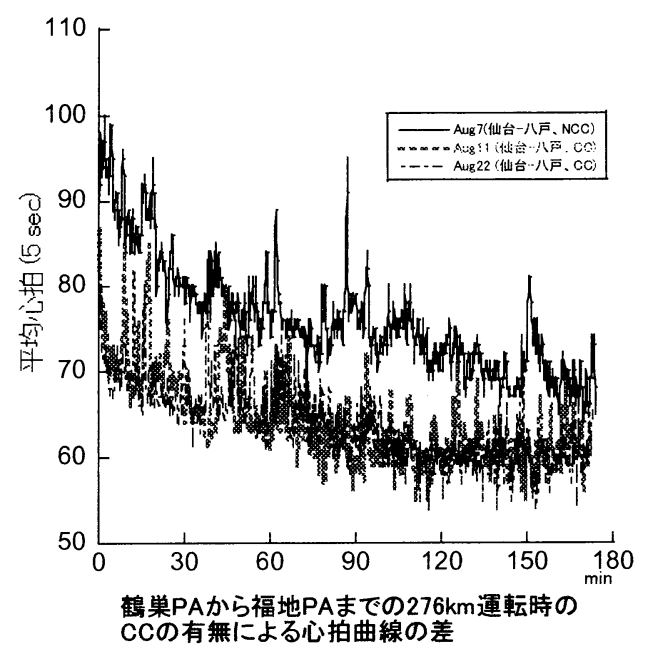

Figure 1

以上より， cc の使用のみで直ちに運転の作業負担 軽減が生じるわけではなく, 交通量の推移などの要 因も交絡するものの，cc はある程度まで心身の緊張 を緩和する効果をもつと思われた。 


\section{テクニカルエイドのシーティングのバリアント タイム特性計測}

内久根聖志 (日本大学 理工学部)

\section{1 . 目的}

一般的に長時間のシーティングは, 生体へ は良くない影響を与えるものと言われている。 長時間の椅座位による原因で袮瘡になって しまう例も挙げられている。これは, テクニ カルエイドである wheelchairにも同様の事が言 えることから，普及されている wheelchair と機 能を高めるための用具を用いて，シーティン グのバリアント特性と身体機能に合わせるテ イルト効果について, 生体への影響を検討し た。生理計測による生理指標としては, 心臟 血管系の反応に, 心拍数, 指尖容積脈波, 血 流, 末梢皮膚温, 呼吸器系の反応としては, 呼吸数, 唾液分泌機能としては, 唾液分泌量, 皮膚伝導に関連した指標には, 皮膚電位反応, 他には, 生体信号, 平衡機能等について計測 した。感性計測については,VASとSD法から バリアントタイム特性による評価項目の相関 を検討した。

2. 方法

スリングシートのシーティング姿勢状態（骨 盤中間位の 30,60 分）についての機能の生理 計測法には条件として, 自律神経系の反射を 介する機能を検出するための方法を取りあげ た。その時系列の 3 分毎に計測した值の最初 の 3 分をベースライン值に取り, 各経過時間 毎の值との比率で示した。座位前・後の場合 とを比較するために平衡機能計, 加速度計, 頭頂部の中央に加速度センサを取り付けて測 定した。身長 $(163.4 \sim 180.0 \mathrm{~cm})$ ，体重 $(519.4$ 〜 931.0N)の $21 \sim 26$ 歳の男子大学生 6 名の 被験者に対して, 平均室温 $296.3 \mathrm{~K}$, 平均湿度 $57.5 \%$ 条件で行った。

3 . 結果

生理指標評価結果としては, 以下に提示す る。心拍波高值比は, 60 分間 1 以上で推移し た。用具使用の場合は, $51 \sim 60$ 分で 1 以下
を示した。中性画像呈示による視覚効果で, 心拍数比の減少は定位反応を反映しているこ とが見出された。呼吸数比は，60 分間 1 以上 で推移したが用具使用の場合は，60 分間で 1 付近で推移した。第 2 指血流は, 36 分まで 1 以上の同傾向を示し, 用具の有無による差異 が 39-57 分で大きく示された。足背動脈部位 の血流は, 用具無しの場合, $57 \sim 60$ 分で低 下が見られたが，用具使用の場合は，1以上 で低下が少ないことを示した。5.9 ${ }^{\circ} ， 10^{\circ}$ のティルトでは, 30 分で低下が見られた。 シーティング後の起立時（メトロノームの 46 拍/分に合わせた座位から立位動作）では, 用具の使用により, 約 5.3 倍の血流量比を示 した。足背部位には，60 分間の筋肉を作用さ せないシーティングにより血流量の減少があ り，立位により筋肉が作用して血流量の機転 が生起したものと思われる。第 2 指血流は, 用具の使用により, 約 1.2 倍の血流量比を示 した。皮膚温度比は, 用具の使用により, middle finger で約 0.98 倍, big toe 部で約 1.0 倍 を示した。VAS法では, コントロールの 30 分 と 60 分を比べると, unpleasant, tired, hardの項目で約 $1.3,1.9,1.6$ 倍評定值の推 移があり, habituationで約 1.1 倍評定值の相 違が示された。SD法では, tiredで用具の有 無による相違は, 30 分と 60 分を比べると, 約 1.2 倍評定值のバリアントタイム特性によ る推移を示した。

\section{4. 考察}

シーティングの使用条件に対するバリアン トタイム特性によるストレイン計測により， 生理指標の変化する傾向が示唆されたことは, 自律神経系各指標の拮抗作用の量的度を関連 付けることにより，生体ストレイン量を反映 する使用条件が必要となる。画像呈示による 視覚情報効果で, 用具, ティルト効果は, 定 位反応を反映することが見出された。

感性計測の評価項目の結果から, 防御反応 を反映しているので, シーティングタイムに よって適するティルト角度は変化することか ら, 変化させる等の対応や設定が必要となる。 


\section{可搬型 PPI システムの開発と実用性の検討}

○田中 邦彦（大阪市立大学大学院 生活科学研究科）

山田 富美雄 (大阪人間科学大学 健康心理学科)

\section{1. 目的}

驚愕性瞬目反射の先行刺激効果の 1 つである先行刺 激抑制効果 (Prepulse inhibition：PPI)は，統合失調 症の薬効検定に用いられ，恐怖との関係も示唆されて いる(山田, 2002)。また驚愕性瞬目反射は注意や感情の 良い指標として用いられており，最近では快・不快な どの感性の評価に用いる実験も行われている(山田, 2002)。このように様々な指標になり得る PPI や驚愕性 瞬目反射の実験は従来，実験室内でしか行われてこな かった。今回，PPI や驚愕性瞬目反射量の測定を実験 室などの屋内だけでなく，屋外などでも簡易に行える ような可搬型 PPI システム(ニホンサンテク株式会社 製 MaP1155SYS) の開発を行った。可搬型 PPI システム はノートPC, 超小型アンプ内臟 1chテレメーターを主 とするシステムである。このシステムの実用性の検討 するため，山田(1984)を元に驚愕性瞬目反射の刺激強 度の効果を調べる基礎実験を行った。

\section{2. 方法}

被験者は男子大学生 5 名で，大阪人間科学大学臨床 生理心理学実験室内で行った。

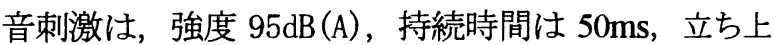
がり/立下り $(\mathrm{r} / \mathrm{f})$ 時間が $1 \mathrm{~ms}$ 以下の白色雑音を基準誘発 刺激とし，強度のみを $85 ， 90 ， 95 ， 100 ， 105 \mathrm{~dB}$ の つに変えた刺激を用いた。音刺激は MaP1000 シリーズ 環境で作られたプログラムによって作成され， PCMICAに取り付けた音源カードを用いてワイヤレス のヘッドホンを介して被験者の両耳に提示された。

驚愕性瞬目反射量は眼輪筋 EMG を小型アンプ内贜 1ch テレメーターによって記録し，MaP1000 シリーズ 環境で作られたプログラムによって刺激提示後 20〜 $120 \mathrm{~ms}$ の眼輪筋 EMG 波形の積分值を算出し求めた。

被験者には椅子に座ってもらい，足元の注視点を見 た状態で実験を行った。 5 種類の音刺激は $5 \times 5$ のラテ ン方格を用いて 25 試行提示した。試行間間隔は 25〜 45s で，平均 35s に設定した。実験開始前に被験者に は, 基淮誘発刺激を $20 \mathrm{~s}$ 間隔で 10 度提示した。実験中, 被験者には基準誘発刺激を聞いて驚いた程度を 100 と して，実験中に提示された音刺激に対する主観的驚愕
度をマグニチュード評定し、口頭で報告させた。

3. 結果

測定された驚愕性瞬目反射量と主観的驚愕度は対数 変換したのち，統計的分析の対象とした。Fig. 1 には 刺激強度が平均驚愕性瞬目反射量に及ぼす効果を図示 する。刺激強度 (5) X試行 (5) の 2 要因の分散分析を行 ったところ, 強度の主効果 $\left(F_{(4,16)}=10.3, p<.001\right)$ が有 意であった。下位検定を行ったところ $85 \mathrm{~dB}$ 条件と $100 \mathrm{~dB}$ 条件, $90 \mathrm{~dB}$ 条件と $100 \mathrm{~dB}$ 条件, $85 \mathrm{~dB}$ 条件と $105 \mathrm{~dB}$ 条件, および $90 \mathrm{~dB}$ 条件と $105 \mathrm{~dB}$ 条件との間に有意な差 が認められた。

主観的驚愕度に関しても刺激強度 (5) メ試行 (5)の 2 要因の分散分析を行ったところ, 強度の主効果 $\left(F_{(4,16)}=10.3, p<.001\right)$ が有意であった。下位検定を行 ったところ，全ての強度間で有意差が確認された。

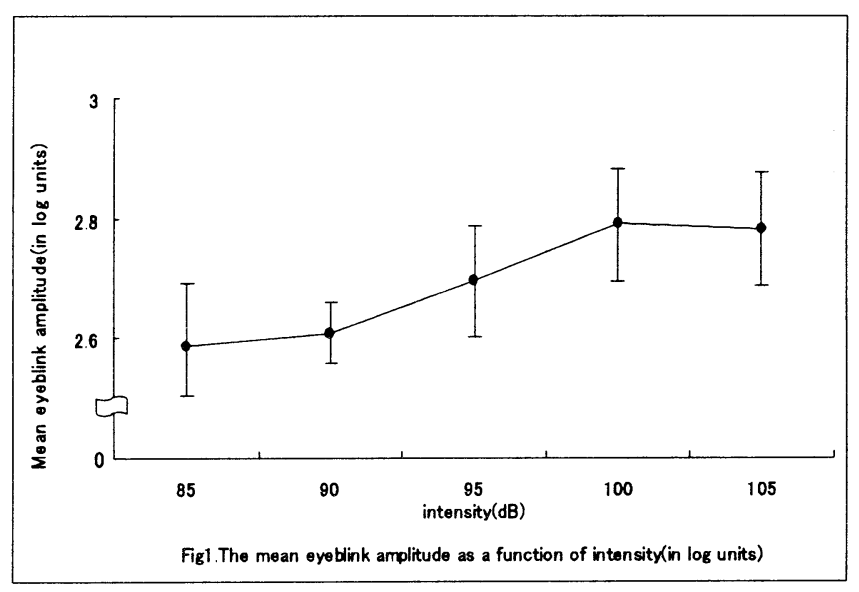

4. 考察

可搬型 PPI システムを使っての刺激強度実験であっ たが, 刺激の作成や提示, リアルタイムでのデータの解 析など問題なく簡易に行うことができた。このことか ら本システムを用いて PPI を容易に測定することが可 能であることが示唆された。

刺激強度効果についての結果には一部検討を要する 問題が残された。驚愕性瞬目反射量が、100dB 条件か ら 105dB にかけて増加しなかったからである。今後さ らに検討を加える予定である。

文献

1) 山田富美雄 2001 瞬目による感性の評価一驚愕性 瞬目反射と自発性反射瞬目による感情評価一心理学 評論 Vol.45, No1, 20-32

2）山田富美雄 1984、聴覚誘発眼輪筋反射と主観的驚 愕度におよぼす誘発刺激の刺激特性効果 生理心理学 


\section{生産方式の違いに対する生体負担の個人差}

橋本 正浩 (産業医科大学生体情報研究センター)

\section{1. はじめに}

生産方式は, 労働者の職務態度・行動に影響を及ぼ す要因の一つである。セル生産方式は，ライン生産方 式と比較して, 仕事のコア次元 (多様性, 完結性, 重 要性, 自律性, フィードバック）が十分に備わってお り，このことが優れた職務態度を生み出し，生産性を 高めることが指摘されている。本研究は, 生産方式の 違いが労働者の生体負担に及ぼす影響を明らかにする ために，(1)ライン生産方式と比較してセル生産方式で は, 作業者のメンタルワークロードが軽減されるのか, (2) 作業者の行動特性は, 生産方式とメンタルワークロ ードの関係にどのような影響を及ぼすか，の 2 点につ いて実験的に検討した。

\section{2. 方法}

\section{(1)被験者}

健康な男子大学生 14 名（20～25 歳, 平均 22.3 歳） を対象とした。

\section{(2)課題}

12 種類 21 部品を用いて電子回路を 90 分間組み立て る作業を課題とした。セル生産方式 (セル条件)では, すべての部品を用いて回路を組み立て，ライン生産方 式（ライン条件）では 4 種類 6 部品を用いて，組立途 中の回路を完成させるよう教示し，1回路当たりに要 する組立所要時間を測定した。なお，セル条件では， 仕事のコア次元のうち, 完結性, 自律性, フィードバ ックを有するように，作業条件を設定した。

(3)行動特性

被験者のタイプ A 行動特性を测定するために, KG 式日常生活質問紙を来室時に記入させ，タイプ $\mathrm{A}$ 得点 を算出した。

(4)測定項目 : 各生産方式に従事したときのメンタルワ ークロードを生理的に評価するために，胸部 $\mathrm{CM}_{5}$ 誘 導で計測した R 波の回帰スペクトルより心拍変動を求 め, 全スペクトルパワー（TP）を算出するとともに， その要素波から血圧の Mayer Wave 成分 (LF) と呼吸性 洞性不整脈成分 (HF) を抽出し, LF/HF 值と HF/TP 值 を算出した。さらに，主観的メンタルワークロードの 指標として，日本語版 NASA-TLX を用い，各下位尺度の 評価値及び加重平均值（WWL）を算出した。

\section{3. 結果}

(1)NASA-TLX

NASA-TLX の平均值を算出したところ, 下位尺度のう ち，「時間的圧迫感」を除いて，他の尺度では両条件 間に差は認められなかった。WWLについても，条件間 の差は認められなかった（セル条件 53，ライン条件 52.9）。しかしながら，TLX の被験者別スコアには大 きな個人間差が認められた。すなわち，ライン条件の TLX スコアがセル条件のスコアより高い群 (5名), セ ル条件のスコアがより高い群 (5名), 雨条件でスコア に差がない群（4名）の3群に大別された。

(2)心拍変動

交感神経系活動指標としての LF/HF 值と迷走神経系 活動指標としての HF/TP 值について, 標準得点に換算 して TLX のスコア別に検討したところ，3 群とも作業 中の HF/TP 值については生産方式条件で有意差は認め られなかった。一方, LF/HF 值については, TLXのスコ アがセル条件で高い群では，生産方式条件間に有意差 が認められた。すなわちここの群では，ライン条件に 比較してセル条件で作業中の LF/HF 值が上昇し, 交感 神経系の亢進が示唆された。これに対して，他の 2 群 では，条件間に有意差は認められなかった。

(3)TYPE A 行動特性

TLX スコアで分類した 3 群について, タイプA得点 を算出したところ, TLX スコアがセル条件で高い群と ライン条件で高い群の間には有意差が認められた。TLX のスコアがセル条件で高い群は，ライン条件で高い群 よりも，タイプA得点が高くなる傾向を示した。

\section{4. 考察}

評価指標として用いた NASA-TLX と心拍変動の結果 は, セル生産方式によって作業者のメンタルワークロ 一ドが一概に軽減されるわけでないこと，異なる生産 方式に対するメンタルワークロードが作業者毎に大き く変動することを示唆した。さらに，作業者の行動特 性は，生産方式とメンタルワークロードの関係に介在 する要因のひとつであることも示唆された。タイプA 行動特性を有する作業者は，多様性，自律性などを特 徵とするセル生産方式において，時間切迫性や競争心 などの冠状動脈疾患傾性行動がより誘発されたため, ライン生産方式よりもメンタルワークロードが増加し たのかもしれない。 


\section{美容介在によるコミュニケーションが高苓者の心身に及ほ す影需 〜喠液試料およひ質問紐を用いた検討〜}

○長濱 由巨子（愛知叔徳大学大学院コシュニケーション研究科）

塩原 正一 (山野美容芸術短期大学美容福祉学科)

斉藤 春江 (山野美容芸術短期大学美容保健学科)

清水 遵 (愛知諔徳大学コミュニケーション学部)

\section{1. 目的}

現在高齢化に関する諸問題が注目されているが, 介護予 防プログラムについては身体的ケアが主体であり、精神的 ケアの確立の急務が要されている。そこで本研究では高齡 者アクテイビティにおけるケアのあり方について検討するこ とを目的に, 専門家が携わる美容の介在がもたらす心身の 活性化を生理学的指標と心理学的指標を用いて検証した。

\section{2. 方法}

(1) 実験参加者; 参加者は埼玉県北本市のデイサービスセ ンター「みなみ風」施設利用者女性 19 名を対象に, メイクを 施すメイク群 11 名, その様子を見ている観察群 8 名の 2 群 に分けた。なお, 簡単な質問内容の理解が可能な高齢者に 限った(MMSE $の$ 得点平均 24.4 点)。期日は, 平成 17 年 8 月 8 日〜 11 月 28 日 13 時加 16 時 30 分で、隔週の計7 回である。なお，実験者は美容を介した介護や福祉に関す る専門家であった。全ての参加者にはインフォームドコンセ ントを十分に行い, 実験協力の承諾を得た。

(2)質問紙調査; 質問紙はフェーススケール, STAI(状態不 安), MMSE, MOSESを用いた。

(3)施術; メイク群にはメイクを行い, 観察群はその場の様子 を見ているだけであった。

(4)唾夜採取之測定; 実験初回・3回目・そして最終回の介入 前後に唾液を採取した。なお，体調不良等でこの条件下で 実験に参加できなかった場合においては次の回に採取した。 採取された唾夜は直ちに冷凍保存され, 後の分析に供され た。MHPG, HVA は HPLC 法によって, また, CgA および s-IgA は酵素免疫検定法によって定量された。

\section{3. 結果と考察}

初回の美容介在活動で得られた各指標に関して, 施術要 因(メイク·観察) と介入要因(前·後)の 2 要因混合分散分析 を行った。ただし、MMSEおよびMOSES の介入要因の水準 は初回の前値, 最終回の後值とした。

フェーススケールに関しては, 介入要因に主効果が認めら れた $(\mathrm{F}(1,13)=10.80, \mathrm{p}<.01)$ (図1)。すなわち, 介入後 に気分が改善されたことが明らかとなった。STAIに関しては，
介入後の状態不安得点が有意に減少した $(\mathrm{F}(1,12)=14.73$, p <.01)。また, MMSE については, 最終回に有意に MMSE 得点が上昇 $(F(1,15)=7.31, \mathrm{p}<.05)$ ，認知機能の向上 が認められた。

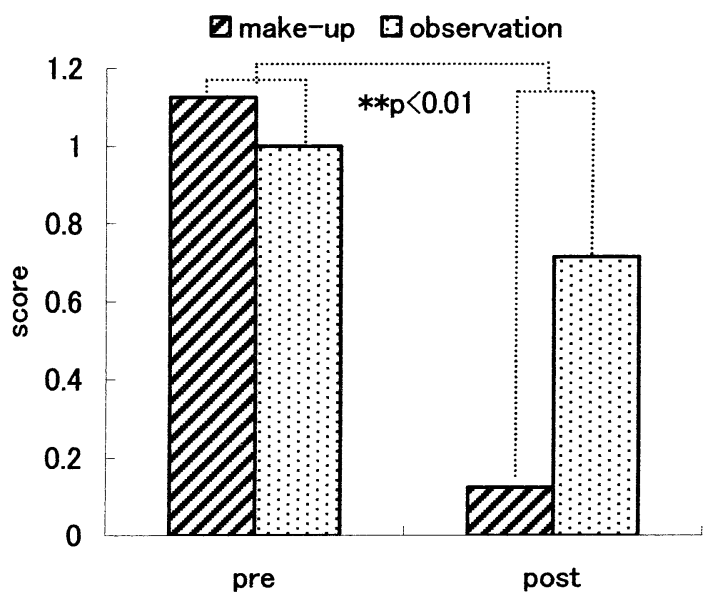

図1 フェーススケールの得点変化

唾夜中 MHPG 濃度に関しては, 介入要因の有意な主効果 が認められ $(\mathrm{F}(1,11)=5.12, \mathrm{p}<.05)$, 介入後に有意な上 昇を示した(図2)。これは, 介在活動がノルアドレナリン作動 性神経系の活性をもたらした結果と考えられる。また - IgA 濃度も同様に介入後に有意な上昇を示し $(F(1,11)=22.26$, $\mathrm{p}<.01)$, 免疫機能の克進を示した(図3)。MOSES および HVA, CgA 指標については有意差が認められなかった。

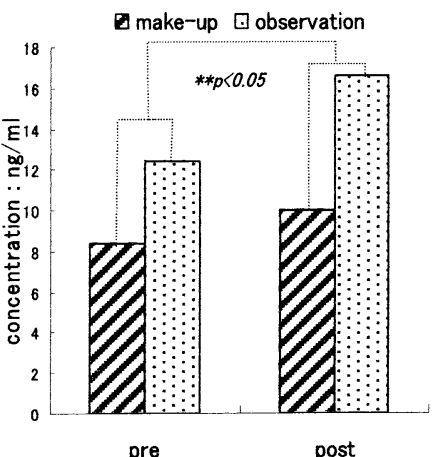

pre

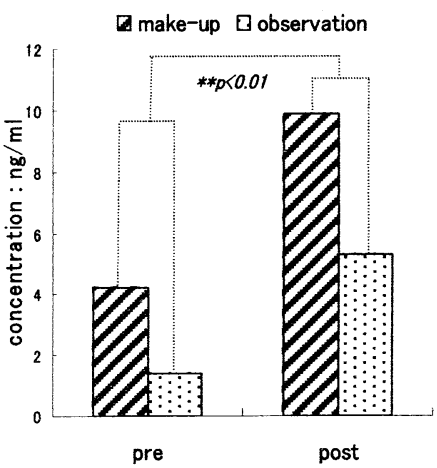

図 $3 \mathrm{~s}-\operatorname{IgA}$ の濃度変化
図2 MHPG の濃度変化 本研究において, メイク群·観察群は共に介入後に気分 の改善, 状態不安の軽減, 脳の活性化, 認知機能及び免疫 機能の向上を示した。これらの結果は美容介在の直接の効 果のみならず, 施術者間のコミュニケーションや場の雰囲気 が高齢者のケアにとって重要であるということを示唆するも のである。今回は美容介在活動の短期的効果について検 討したが, 今後は更に長期にわたる詳細な検討を加え, 実 践的なプログラム構築のための基礎研究が望まれる。 
活気を高めるポジティブ感情が免疫系に及ぼす効果

○松永 昌宏 (名古屋大学大学院勡学研究科)

(愛知医科大学消化器内科)

大平 英樹 (名古屋大学大学院噮境学研究科)

\section{1. 研究の青暴, 目的}

$\lceil A$ cheerful heart is good medicine, but a crushed spirit dries up the bones（陽気な心健康を良くし、陰気な心情を枯ら す)」

旧約聖書の中に書かれているように，はるか剒からポジ ティブな感情は健康に良い影響を及ぼすと信じられてい た。興味梁い事に，ボジティブな感情を普段から多く喚起 している人たちは, 風邪をひきにくく健康であるというこ とが最近報告された（Cohen et al., 2003）。また，ポジティ ブ感情が最もよく経験され，他人から見ても相手がポジテ イブな感情にあることを認儎出来るものに「笑いがある が，「笑いはは我々の体内に侵入したウイルスを攻撃する 役割を持つ自然免疫系細胞の一種であるナチュラルキラ 一（NK）細胞の活性を高めるという報告も最近出されて いる (Takahashi et al., 2003)。このように, ポジティブな感 情が健康に及ぼ寸良い影響についての科学的な知見が最 近得られつつある。本研究では, ポジティブ感情が末梢自 律神経系, 内分泌系, 免疫系に及ぼす効果を検証すること を目的として解析を行った。

\section{2. 方法}

本実験では, ポジティブ感情として「好き (Attraction to favorite person)」に着目した。12 名の被験者 (男性 6 名, 女性6名)に感情的に中性なニュースの映像 (Neutral film) と，好きな人，憧れている人の映像 (Attractive film)を 10 分間見てもらい心理・末梢自律神経・内分泌・免度指標 の変化を解析した。心理指標として現在の気分状態，末梢 自律神経指標として心拍数と皮膚コンダクタンス水準 (SCL), 内分泌系指標として血中ノルアドレナリン, ア ドレナリン, コルチゾル, エンドルフィン嶩度, 兔疫指標 としてリンパ球の中のNK細胞と $\mathrm{T}$ 細胞の比率を解析した。

\section{3. 結果}

心理指標：気分状態を「活気」「気分」「疲労」「不安」「緊 張」「落ち着き」の 6 項目, 7 件法で評価したところ, 「Attraction」を喚起させた後は「活気」が高まり，「気分」
がよくなっていた。

兔疫指標 : 興味染い事に,「Attraction」を喚起させた後で は, リンパ球中の NK 細胞の比率が高まっていた。リンパ 球中の T 細胞の比率には変化が見られなかった。

末梢自律神経指標：映像を見て「Attraction」が喚起され ている間は, 心拍数に変化は見られなかったが, SCLの上 昇が見られた。

内分泌指標：今回、ノルアドレナリン,アドレナリン， コルチゾル, エンドルフィンの血中濃度の変化を測定した がどのホルモンにも有意な変化は見られなかった。

\section{4. 考察}

被験者に好きな人，憧れている人の映像を見せると，活気 が高まるポジティブ感情を喚起させる事が出来た。そして 興味深い事に,このポジティブ感情を喚起させた後ではリ ンパ球中の NK 細胞の比率が高まっていた。映像を注視し ている時に交感神経系の指標である SCL が増加していた 事から，活気を高めるポジティブ感情は，交感神経系を介 して自然免疫系を活性化する可能性が示唆された。

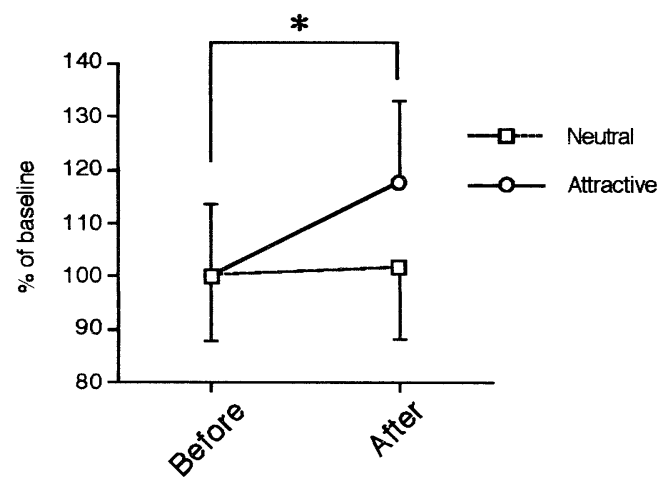

Fig. 映像注視前後のリンパ球中のNK細胞の割合の変化 Neutral: ニュートラル映像 Attractive：好きな人，憧れている人の映像 ${ }^{*} P<0.05$ vs 映像を見る前。

\section{5. 考考文眮}

1. Cohen, S., Doyle, W. J., Turner, R. B., Alper, C. M., \& Skoner, D. P. (2003). Psychosomatic Medicine, 65, 652657.

2. Takahashi, K., Iwase, M., Yamashita, K., Tatsumoto, Y., Ue, H., Kuratsune, H., Shimizu, A. \& Takeda, M. (2001). Int J Mol Med., 8, $645-650$. 
温泉と水道水による半身浴の生理的 . 心理的影響の検証（1） 一気分とストレスホルモンへの影響

○佐々木 百恵 (福井大学医学部) 長谷川 智子 (福井大学医学部) 上原 佳子 (福井大学医学部) 上木 礼子 (福井大学医学部) 米澤 弘恵 (元福井大学医学部) 上野 栄一 (福井大学医学部)

\section{I. 目的}

温泉は古くから日本人の保健・休養に大きな役割を果 たしてきた。医療においても，高血圧症や末梢循環障害 を対象に泉質の薬理作用による効果や温熱効果を利用し たり,リハビリテーションなどに活用されている。今回， 福井県三方郡美浜町のナトリウム一炭酸水素塩温泉水と 水道水での半身浴の生理的・心理的影響を明らかにする 目的で，ヒトに対する実験研究を行い，健康增進のため の温泉浴の有效活用について検討した。本報では特に， 気分とストレスホルモンへの影響について分析した。

II. 方法

1. 対象

健康状態に問題のない男子大学生 6 名 (平均年齢: 23.5 \pm 1.5 歳, 体重 : $65.9 \pm 13.0 \mathrm{~kg}$, 体脂肪率 : $15.2 \pm 9.2 \%$ )

\section{2. 調查項目}

1) 主観的評価

(1) 気分プロフィール検査 (Profile of Mode States : POMS）下位尺度 :「緊張」「抑うつ」「怒り」「活気 「疲労」「混乱」

(2) 眠気評価

眠気尺度 (Kwansei-gakuin Sleepiness Scale : KSS)

2) 生理学的評価

（1）血漿カテコールアミン

アドレナリン, ノルアドレナリン, ドーパミン $(\mathrm{ng} / \mathrm{ml})$ (2) 血中コルチゾール $(\mu \mathrm{g} / \mathrm{dl})$

\section{3. 実験方法}

対象者は実験開始前に排尿を済ませ，アイソトニッ ク飲料 $200 \mathrm{ml}$ を飲用した。その後 10 分間の半座位安

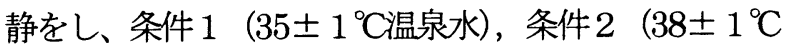

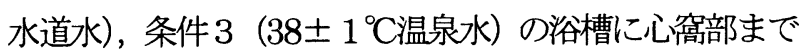
の半身唂を 30 分間実施した後、再び半座位での安静 30 分間を実施した。条件 $1 \sim 3$ の順序が被験者毎に異なる ように調整した。実験前後に留置した留置針より血液を
採取した。対象者の主観的評価では，自記式留置法にて $\mathrm{POMS}$ ・KSS への回答を行った。POMS は，58 項目に ついて尺度毎に構成項目の得点を合計し採点した。KSS は，22 項目に各々 $0 \sim 7$ の範囲で尺度值があり，尺度の 平均を測定時点での眠気として採点した。生理学的評価 は，実験前の值を基準値とし，実験後の值から実験前の 值を割り変化率（\%）を求め比較した。

\section{4. 倫理的配慮}

研究の目的を公表し研究参加者を募った。研究参加者 への依頼は, 書面と口頭で行い, 研究への参加は自由意 志であること, また, 研究への参加はいつでも拒否でき, 不利益は生じないことを説明し同意を得た。対象者のプ ライバシーと匿名性を厳守し, データの処理は全てコン ピュータ処理を行い，個人が特定できないようにした。 なお, 研究実施に当たり, 福井大学医学部研究倫理審査 会の承認を得た。

III. 結果

POMS では, $38^{\circ} \mathrm{C}$ 水道水での「怒り」以外の項目は全 て低下した。温泉水では全ての項目が減少し, 特に $38^{\circ} \mathrm{C}$ 温泉水では，「怒り」「疲労」の項目が低下した。KSSで は, 全ての条件において低下傾向が認められ，特に温泉 水での低下が顕著であった。

アドレナリンでは， $35^{\circ} \mathrm{C}$ 温泉水では増加 1 名・減少 1 名・変化なし 4 名, $38^{\circ} \mathrm{C}$ 水道水では増加 1 名・減少 2 名・ 変化なし 3 名, $38^{\circ} \mathrm{C}$ 温泉水では堌加 2 名・減少 1 名・変 化なし 3 名であった。 $38^{\circ} \mathrm{C}$ 温泉水ではやや増加傾向が認 められたが, 変化なしが多かった。ノルアドレナリンで は, $35^{\circ} \mathrm{C}$ 温泉水では増加 3 名・減少 1 名・変化なし 1 名, $38^{\circ} \mathrm{C}$ 水道水では堌加 2 名・減少 4 名, $38^{\circ} \mathrm{C}$ 温泉水では増 加 5 名・変化なし 1 名で, 温泉水では増加傾向であった。 ストレス指標であるコルチゾールの平均変化率をみると， $35^{\circ} \mathrm{C}$ 温泉水では全員減少， $38^{\circ} \mathrm{C}$ 水道水では増加 2 名・減 少 4 名, $38^{\circ} \mathrm{C}$ 温泉水では増加 1 名・減少 5 名で, 全体的 に減少傾向であり，水道水よりも温泉水で大きかった。 IV. 考察

温泉浴が，「緊張「抑うつ」怒り」疲労」「活気」「混 乱, コルチゾールの低下をもたらすことは, 温泉浴が交 感神経系や副交感神経系に大きな影響を与えていること が示唆された。これらの結果から, 半身浴がリラグゼー ション効果を起こすことが示唆された。入浴によりネガ ティブな気分は減少するが，特に温泉入浴ではストレス ホルモンの減少が認められた。 本研究は，福井県三方郡美浜町との共同研究による成果である。 
温泉と水道水による半身浴の生理的. 心理的影響の検証 (2) 一循環能への影㻗—

○上原 佳子 (福井大学医学部) 長谷川 智子 (福井大学医学部) 上木 礼子 (福井大学医学部) 佐々木 百恵 (福井大学医学部) 米澤 弘恵 (元福井大学医学部) 上野 栄一 (福井大学医学部)

\section{I. 目的}

温泉は古くから日本人の保健・休養に大きな役割を果 たしてきた。医療においても，高血圧症や末梢循環障害 を対象に泉質の薬理作用による効果や温熱効果を利用し たり、リハビリテーションなどに活用されている。今回， 福井県三方郡美浜町のナトリウム一炭酸水素塩温泉と水 道水での半身浴の生理的・心理的影響を明らかにする目 的で，ヒトに対する実験研究を行い，健康増進のための 温泉浴の有效活用について検討した。本報では特に，循 環能への影響について分析した。

II. 方法

1. 対象

健康状態に問題のない男子大学生 6 名 (平均年齢: 23.5 \pm 1.5 歳, 体重 : $65.9 \pm 13.0 \mathrm{~kg}$, 体脂肪率 : $15.2 \pm 9.2 \%$ )

2. 調查項目

1) 生理学的評価

（1）心拍数 : 多用途テレメーター（サイナアクト 11）に て 1 分毎に測定

(2) 収縮期血圧/拡張期血圧:オムロンデジタル血圧計に て5分ごとに測定，分析には平均血圧を用いた。

(3)Perfusion Index (以下, PI) : Radical signal extraction pulse oximeter (MasimoSET)を用いて 1 分毎に測定。PI=(拍動量/無拍動量) $\times 100$ にて算出。

2) 生化学的評価

血漿レニン $(\mathrm{ng} / \mathrm{ml} / \mathrm{h})$ ，血漿アルドステロン $(\mathrm{ng} / \mathrm{dl})$, ヒト心房性 $\mathrm{Na}$ 利尿ポリペプチド（hAMP） (pg/ml)

\section{3. 実験方法}

対象者は実験開始前に排尿を済ませ，アイソトニッ ク飲料 $200 \mathrm{ml}$ を飲用した。その後 10 分間の半座位安 静をし、条件 1 (35 $\pm 1^{\circ} \mathrm{C}$ 温泉水)，条件 $2\left(38 \pm 1^{\circ} \mathrm{C}\right.$ 水道水), 条件 3 (38 $11^{\circ} \mathrm{C}$ 温泉水) の浴槽に心窩部まで の半身浴を 30 分間実施した後、再び半座位での安静 30 分間を実施した。条件 1 〜 3 の順序が被験者毎に異なる
ように調整した。実験前後に留置した留置針より血液を 採取した。生理学的評価では, 入浴前の值を基淮値とし, 入浴中および入浴後の 5 分間隔の值を入浴前の值で割り 変化率 (\%) を求め, 比較した。生理学的評価は, 実験 前の値を基淮值とし，実験後の值を実験前の值で割り変 化率（\%）を求め比較した。

\section{4. 倫理的配慮}

研究の目的を公表し研究参加者を募った。研究参加者 への依頼は, 書面と口頭で行い, 研究への参加は自由意 志であること, また, 研究への参加はいらでも拒否でき, 不利益は生じないことを説明し同意を得た。対象者のプ ライバシーと匿名性を厳守し, データの処理は全てコン ピュータ処理を行い，個人が特定できないようにした。 なお, 研究実施に当たり, 福井大学医学部研究倫理審査 会の承認を得た。

III. 結果および考察

1. 生理学的評価

• $35^{\circ} \mathrm{C}$ 温泉水では，心拍・血圧で対象者に共通した大き な変化はみられず，PI では入浴中・後とも减少がみられ た。 $35^{\circ} \mathrm{C}$ の中立音での入浴では循環動態への影響が少な いが，血流促進効果も少ないことが考えられる。

- 心拍では, $38^{\circ} \mathrm{C}$ 水道水に比べ， $38^{\circ} \mathrm{C}$ 温泉水の方が入浴 中緩やかに変化していた対象者が多かった。血圧では温 泉水・水道水とも入浴直後に静水圧の影響によると思わ れる一時的な血圧上昇がみられたが，温泉水ではその後 全員の血圧が水道水よりもすみやかに低下していた。PI では，温泉水で入浴中増加がみられた。これらり，温 泉水の半身浴では，心拍数の増加が緩やかな状態で血流 が促進され，身体に負担をかけることなく血流が促進さ れていたと考えられる。

\section{2. 生化学的評価}

・血漿レニンは，温泉水では増加がみられ，その変化率 は $38^{\circ} \mathrm{C}$ 方が大きく，水道水では個人差がみられた。血 漿アルドステロンの変化は個人差が大きく, 泉質・温度 による変化の差はみられなかった。 hAMPは， $38^{\circ} \mathrm{C}$ 温泉 水で 1 名のみ $40 \%$ 増加がみられたが，他は全く変化がな

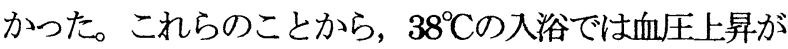
あっても，その変化は一時的であり，心媍荷の程度は少 ないと考えられる。

IV.まとめ

温泉水での入浴は，水道水よりも身体に負担をかける ことなく循環を促進させることが考えられる。 本研究は，福井県三方郡美浜町との共同研究による成果である。 
温泉と水道水による半身浴の生理的・ 心理的影響の検証 (3) 一消化器能と免疫能への影響

○上木 礼子 (福井大学医学部)

長谷川 智子 (福井大学医学部)

上原 佳子 (福井大学医学部)

佐々木 百恵 (福井大学医学部)

米澤 弘恵 (元福井大学医学部)

上野 栄一 (福茾大学医学部)

\section{I. 目的}

温泉は古くから日本人の保健・休養に大きな役割を果 たしてきた。医療においても，高血圧症や末梢循環障害 を対象に泉質の薬理作用による効果や温熱効果を利用し たりリハバリテーションなどに活用されている。今回， 福井県三方郡美浜町のナトリウム一炭酸水素塩温泉水と 水道水での半身浴の生理的・心理的影響を明らかにする 目的で，ヒトに対する実験研究を行い，健康増進のため の温泉浴の有效活用について検討した。本報では特に, 消化器能と免疫能への影響について分析した。

II. 方法

1. 対象

健康状態に問題のない男子大学生 6 名 (平均年齢: 23.5 \pm 1.5 歳, 体重 : $65.9 \pm 13.0 \mathrm{~kg}$, 体脂肪率 : $15.2 \pm 9.2 \%$ )

2. 調査項目

1) 消化器能

（1）血中グルコース $(\mathrm{mg} / \mathrm{dl})$

(2) 血中インスリン $(\mu \mathrm{U} / \mathrm{ml})$

（3）血中ガストリン $(\mathrm{pg} / \mathrm{ml})$

2）免疫能

(1) CD4 (\%)

(2) $\mathrm{CD} 8(\%)$

(3) $\mathrm{CD} 4 / \mathrm{CD} 8$ 比

3. 実験方法

対象者は実験開始前に排尿を済ませ，アイソトニッ ク飲料 $200 \mathrm{ml}$ を飲用した。その後 10 分間の半座位安

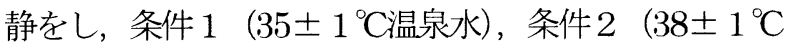
水道水)，条件 $3\left(38 \pm 1^{\circ} \mathrm{C}\right.$ 温泉水）の浴槽に心窩部まで の半身浴を 30 分間実施した後, 再び半座位での安静 30 分間を実施した。条件 $1 \sim 3$ の順序が被験者毎に異なる ように調整した。実験前後に留置した留置針より血液を 採取した。得られた調査結果の評価は，実験前の値を基 準值とし，実験後の值から実験前の值を割り変化率 (\%)
を求め比較した。

4. 倫理的配慮

研究の目的を公表し研究参加者を募った。研究参加者 への依頼は，書面と口頭で行い，研究への参加は自由意 志であること, また, 研究への参加はいつでも拒否でき, 不利益は生じないことを説明し同意を得た。対象者のプ ライバシーと匿名性を厳守し，データの処理は全てコン ピュータ処理を行い，個人が特定できないようにした。 なお, 研究実施に当たり, 福井大学医学部研究倫理審査 会の承認を得た。

III. 結果

消化器能では, 血中グルコース値, 血中インスリン值, 血中ガストリン值は, 3 つ条件のすべてで半身浴後に低 下寸る傾向が見られた。血中グルコース值は，38ㄷ温泉 水のとき変化率が大きく, $35^{\circ} \mathrm{C}$ 温泉水， $38^{\circ} \mathrm{C}$ 水道水に比 心゙ても低下する傾向が大きかった。血中インスリン值は， $35^{\circ} \mathrm{C}$ 温泉水および， $38^{\circ} \mathrm{C}$ 温泉水では，やや低下が著明で あった。血中ガストリン值は，半身浴により低下する傾 向が見られた。

免疫能の指標である CD 4, CD 8 では半身浴後の変化 は少ないが, $38^{\circ} \mathrm{C}$ 温泉水での半身浴のとき $\mathrm{CD} 4$ がより上 昇する傾向が見られた。免疫活動の指標となる CD4/CD8 比で見ると, $38^{\circ} \mathrm{C}$ 水道水, $38^{\circ} \mathrm{C}$ 温泉水で上昇する傾向が 見られた。

IV. 考察

3 条件での血中グルコース値と血中インスリン值の評 価加, 温泉水の半身浴は水道水より代謝を六進させ, エネルギーを消費させる傾向が明らかとなった。

血中ガストリン值が半身浴により下がる傾向は，グル コース值やインスリン值の低下など他の要因による影響 も考えられる。温度と泉質による違いは認められなかっ た。

免疫能の評価として，入院患者の長期の入浴において CD8 が上昇したという報告があるが，本研究では CD4 の上昇がみられた。このことより，半身浴ではへルパーT 細胞への影響が推察されるが，この件については今後も 継続した研究が必要であろう。

免疫系が活性状態にある場合に CD4/CD8 比が増加す る傾向にあるとされるが，半身浴による温刺激が免疫活 動に影響がある可能性が示唆された。

本研究は, 福井県三方郡美浜町との共同研究による成 果である。 